th. 1620 ORNLIENGTM-12

Múici

\title{
Safety Analysis Report for Packaging: The ORNL HFIR Spentfuel-Element Shipping Cask
}

\author{
J. H. Evans \\ K. K. Chipley \\ R. E. Eversole \\ R. A. Just \\ G. H. Llewellyn
}


ORNL/ BNG/TM-12

Dist. Category UC-71

Contract No. H-7405-eng-26

ORNL Engineering

SAFETY ANALYSIS REPORT FOR PACKAGING:

THE ORNL HFIR SPENT-TUEL-ELEMENT SHIPFING CASK

J. H. Evans

K. K. Chipley

R. E. Eversole

R. A. Just

G. H. Llewellyn

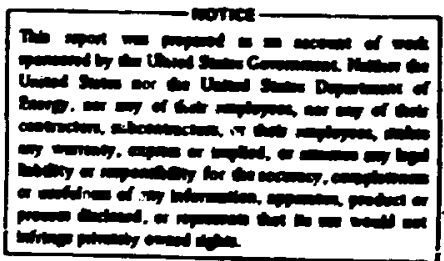

intim

Date Published: November 1977

OAK RIDGE NATIONAL LABORATORY

Oak Ridge, Tennesse? 37830

operated by

UNION CARBIDE CORPORAT TON

for the

DEPARTMENT OF ENERGY 
conTmiss

LIST OF FIGURES . . . . . . . . . . . . . . . . . . v

LIST OF TABLES .............. . . . . . . . . . IX

ABSTRACT . . . . . . . . . . . . . . . . . 1

0. getrRal IMfORMATIOA . . . . . . . . . . . . . 1

0:1 Introduction . . . . . . . . . . . . . . . . . 1

0.2 Package Description ................. 2

0.2.1 Operational Features ............. 4

0.2 .2 Contents ................. 4

1. STRUCTURAL EVALUATION ................. 7

1.1 Hechanical Properties of Materials . . . . . . . . 9

1.2 General Standards for All Packages . . . . . . . . . 11

1.2.1 closure .................. 11

1.2.2 Cask-Lifting Devices ............ 15

1.2 .3 Lid-Lifting Devices ............ 17

1.2.4 Tie-Down Devices . . . . . . . . . . . . 21

1.3 Compliance with Structural Standards for Packaging . . 26

1.3.1 Load Resistance ............... 26

1.3.2 External Pressure . . . . . . . . . . . 29

1.4 Compliance with Standards for Normal Conditions

of Transport ..................... 31

1.4 .1 heat . . . . . . . . . . . . . 32

1.4 .2 cold .................. 32

1.4 .3 Pressurs ................. 33

1.4 .4 Vibration ............... 33

1.4 .5 Water Spray ................ 35

1.4 .6 Free Drop . . . . . . . . . . . . . . 35

1.4.7 Penetration ................ 37

1.5 Compliance with Standards for Hypothetical Accident

Conditions . . . . . . . . . . . . . . 4 42

1.5.1 Thirty-ft Free Fall .............. 43

1.5.2 Puncture . . . . . . . . . . . . . 81

1.6 Containment Vessel Design Pressure ... . . . . . . 82

1.7 Thermal and Thermal Expansion Stress . . . . . . . . 82

1.7.1 Normal Conditions of Transport . . . . . . . . 84

1.7.2 Accident Conditions ............ 84

2. THERMAL EVAlUation . . . . . . . . . . . . . 9 90

2.1 Discussion . . . . . . . . . . . . . . . 9 90

2.2 Thermal Properties of Materials ............. 91

2.3 Thermal Evaluation for Normal Conditions of

Transport . . . . . . . . . . . . . . . . 96

2.3.1 Thermal Model ................96

2. 3.2 Maximum Temperatures . . . . . . . . . . 99 
2.3.3 Maim Temperatures . . . . . . . . . 99

2.3.4 Maxim Internal Pressure .......... 102

2.4 Hypothetical Thernal Accident Evaluation . . . . . 102

2.4.1 Thernal Hodel ............... 102

2.4.2 Thermal Accident Analysis .......... 103

2.4.3 Analysis Results .............. 103

2.4.4 Internal Pressure .............. 103

3. comanamit .................... 103

3.1 Containment Boundaries . . . . . . . . . . . . 103

3,2 Requiresents for Normal Transport . . . . . . . . . 106

3.3 Containent Requirements During the Hypothetical

Accident . . . . . . . . . . . . . . . 106

4. shflelding .................... 106

4.1 Norteal Conditions .................. 106

4.2 Accident Conditions ................ 108

5. CRItICALITI . . . . . . . . . . . . . 109

6. QUAJITY ASSURANCS . . . . . . . . . . . . . 109

5.1 Operating P:- scedures and Routine Inspection....... 110

6.2 Periodic Majntenance and Inspection .......... 110

REFERENCBS .......................... . . 111

APPENDIX A - As-Bulle Drawings . . . . . . . . . . 115

APPERDIX B - Approval Documents . . . . . . . . . . . 129

APFENDIX C - Element Drarings: HFIR-Element Drawings, ORR

Elements . . . . . . . . . . . . . . 135

APPENDIX D - De ay HeR: Calculations for ORR Element . . . . . 143

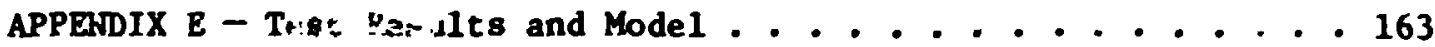

APPENDIX F - Comp $\because$ Derfuations, 1010 CASR, 1005 CASK,

$10 ! 5$ :3SK . . . . . . . . . . . . . 171

APPENDIX G - Oper ; 1 Ing Procedures and Inspection Check1lsts . . . 193

APPENDIX H - ACstrtent Shielding Analysis . . . . . . . . . 209

APPENDIX I - Crilícality Review Forms ............. . 213

APPENDIX J - Quality Assurance Program Plans . . . . . . . . 225 


\section{LIST OF FIGURES}

Figure

C.1 HFIR cask loaded with a complete HFIR core........ 3

0.2 HFIR cask with ORR elements loaded .......... 5

0.3 HFIR element .................. 6

0.4 Typical ORR-type elements ............ 8

1.1 Volumetric expansion of lead and stainless steel as a function of temperature .............. 10

1.2 Dynánic compressilve stress-strain diagram for lead .................. 12

1.3 Dynamic tensile siress-strain curves for 18-8 stainless steel .................... 13

1.4 Dynamic compressive stress-strain curves . . . . . . 14

1.5 Cask-1ffting lug ................ 16

1.6 Lifting-lug sections ............... 18

1.7 Lid-1ifting lug ............... 19

1.8 Bolted cask tie-down (direct to cruck bed) . . . . . 22

1.5 Force diagram . . . . . . . . . . . . . . 24

1.10 Arrangements of pipes around outer shell . . . . . . 27

1.11 Absolute pressure diagram . . . . . . . . . . 34

1.12 Two-ft drop impact on side - case I . . . . . . . 38

1.13 Two-ft drop Impact on side - case I ........ 39

1.1.4 Two-fr drop tmpact on side - case II . . . . . . . 40

1.15 Two-ft drop impact on side - case II . . . . . . . 41

$1.162 .35-t 0-1$ test model (drawing) ........... 45

$1.172 .35-t o-1$ test model (photograph) .......... 46

1.18 Damaged models.................. 47 
Model data ................... 49

1.20 End Imact, energy absorbed in eight extended plpes..................... 50

1.21 End Imact, energy absorbed in the cask body . . . . . 51

1.22 End impact - deformation of lead shielding . . . . . \$2

1.23 End Inpact - defornation of elght extended pipes . . . 53

1.24 side-drop orientations . . . . . . . . . . 55

1.25 Plpe iopact data ............... 58

1.26 Side-drop responses of two pipes ........... 61

1.27 Side-drop dynamic yield stress $=6000 \mathrm{psi} \ldots 63$

1.28 Side-drop dynamic yleld stress $=14,000 \mathrm{ps1}$..... 64

1.29 Side-impact dynamic yleld stress $=14,000$ psi .... 65

1.30 Side-impact response of two pipes .......... 66

1.31 Energy deflection curve for one pipe .........67

1.32 Plug force diagram ............... 69

1.33 Corner-impact módel . . . . . . . . . . 72

1.34 Corner-impact model . . . . . . . . . . . 73

1.35 Damage to corner-impact model from $30 \mathrm{ft} \ldots . . . . .74$

1.36 Damage to corner-impact model from $10 \mathrm{ft} . . . . . .75$

1.37 Corner Impact - energy absorber . . . . . . . . . 77

1.38 Corner Impact - cask body . . . . . . . . . . 78

1.39 Corner Impact - shielding deformation . . . . . . 79

1.40 Corner Impact - absorber deformation . . . . . . . 80

1.41 Contalnment vessel . . . . . . . . . . . 83

1.42 Dlagram of lead melt ............... 85

2.1 Heat transfer model cask loaded with HFIR cote... . . 97, 
Figure

2.2 Heat transfer model cask loaded with 17 ORR

elements................... 98

2.3 Temperature location diagram (HFIR core) . . . . . . 101

2.4 Temperature location diagram (ORR ioading) . . . . . i01

2.5 Teuperature of cask loaded with HFIR core during fire

simulation ................. . 104

2.6 Temperature of cask loaded with HFIR core . . . . . 105

3.1 Gasket service temperatures (ref. 19) . . . . . . 107

A.1 Drawing no. Ml0191-EL-001-D . . . . . . . . . 117

A.2 Drawing no. M10191-EL-002-D . . . . . . . . . 118

A.3 Drawing no. Ml0191-EL-003-D . . . . . . . . . 119

A.4 Drawing no. Ml0191-EL-004-D . . . . . . . . . 120

A.5 Drawing no. Ml0191-EL-005-D . . . . . . . . . 121

A. 6 Drawing no. Ml0191-EL-006-D . . . . . . . . . 122

A. 7 Drawing no. M10191-EL-007-C . . . . . . . . 123

A. 8 Drawing no. Ml0191-EK-008-D . . . . . . . . . 124

A.9 Drawing no. M10191-EM-009-D . . . . . . . . . 125

A. 10 Drawing no. M10191-EM-010-D . . . . . . . . 126

A.11 Drawing no. M10191-EM-011-D . . . . . . . . 127

A.12 Drawing no. M10191-EM-012-D . . . . . . . . . . 128

C.1 Drawing no. D-42118 . . . . . . . . . . . 137

C. 2 Drawing no. D-42126 .............. 138

C.3 Drawing no. M-20394-EJ-003-D . . . . . . . . 139

C.4 Drawing no. M-20394-EJ-002-D . . . . . . . . 140

C.5 Draking no. M-20́394-EJ-001-D ............ 141

C.6 Drawing no. M-20394-EJ-004-D ............ 142 
Plgure

B.1

HFIR spent-fuel shipping cask ........... 166

E. 2

HFIR Imact test bodel . . . . . . . . . . 167

E.3

Typical load cell hook-up

168

F.1

Casix model

174

F.2

Cask nodel 


\section{LIST OF TABLES}

Table

Page

1.1 Static mechanical properties of cask materials . . . . 9

1.2 Test parameters .............. 56

2.1 Material properties for HFIR lo?ding . . . . . . 92

2.2 Material properties used in thereal analysis for ORR

loading . . . . . . . . . . . . . . . . 93

2.3 Cask temperatures with HFIR core . . . . . . . . 100

2.4 Cask temperatures with 17 ORR elements . . . . . . 100 
SAFETY ANALYSIS REPORT FOR PACKAGING:

HFIR SPENT-FUEL-ELPAIENT SHIPPING CASK

J. H. Evans R. R. Chipley R. E. Eversole

R. A. Just G. H. Llewellyn

\begin{abstract}
The Oak Ridge National Laboratory High Flux Isotope_Reactor (HFIR) spent-fuel-element shipping cask is used to transport HFIR, Oak RIdge Research Reactor (ORR), and other reactor fuel elements. The cask was analytically evaluated to cetermine its compliance with the applicable regulations governing containers in which radioactive materials are transported, and that evaluation is reported herein. Computational procedures and tests were used to determine behavior of the cask relative to the general standards for the hypothetical accident conditions. The results of the evaluation show that the cask is in compliance with the applicable regulations.
\end{abstract}

\title{
0. GENERAL INFORMATION
}

\subsection{Introduction}

The High Flux Isotope Reactor (HFIR) spen'-fuel-element shipping cask was designed in 1964 by the Oak Ridge National Laboratory (ORNL) General Engineering and Construction Divigion. Fabrication by ORNL and Y-12 shops was completed in 1964. The cask is now the property of the ORNL Operations Division. Both the design and the fabricated cask complied with the Atomic Energy Commission (AEC) regulations in effect at that tiue, and a report ${ }^{2}$ demonstrating compliance was prepared and published. The cask has been used since the HFIR was placed in operation in 1966 to ship spent elements for reprocessing. To date, all shipments have been made without incident via highway trailer, but the cask can also be used for rall and water transport.

Minor revisions will be made to the cask to make it adaptable for shipplng Oak Ridge Research Reactor (ORR) and other similar spent-fuel elements, to improve the versatility of the cask, and to protect the closure. The cask will undergo the modification upon approval of this safety analysis report for packaging (SARP) by the Oak Ridge Operations 


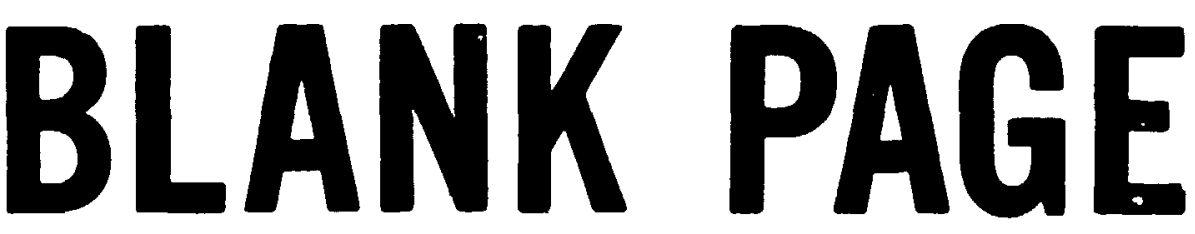


Office (ORO) of the Department of Energy (DOE). All analyses and description of the cain presented here reflect the wiodifications to be made. These revisions are 1llustrated in the as-built draw ngs in Appendix A. The revised cask complies with DOE, Code of Pederal Regulations, Title 10, Part 71,3 ERDA Manual Chapter 0529, 4 and all Inediate Action Directives (IAD) in effect at the date of this report. The cask also complies with U.S. Department of Transportation (DOT) regulations, Code of Federal Regulations, Title 49, Part 173.5 Calculations, engineering logic, test results, and documents demonstrating compliarce are presented in later sections of this report. Copies of the approval documents are reproduced In Appendix B.

\subsection{Package Description}

The salient features of the cask are fllustrated in Fig. 0.1. Asbuilt abrication drawings are in Appendix $A$. The cask and contents weigh $23,000 \mathrm{lb}$. The cast-in-place lead shielding is clad with type 347 stainless steel. The cask is $72-1 / 2$ in. overall length by 46-3/8 in. $O D$. There is one cavity, 17-7/8 in. ID by $32 \mathrm{in.} \mathrm{1ong.} \mathrm{The} \mathrm{cask} \mathrm{has} \mathrm{one}$ drain line and one penetration for sampling the cavity atmosphere and pressure testing. The closure is the cavity shield plug. The plug is secured to the body by fourteen 1-1/2-in. alloy steel studs, one of which is drilled for seal wiring. Nuclear subcriticality for the HFI? element is ensurad by the poison post and poison annulus. For shipping ORP elements, a magazine witn poison-containing partitions replaces the HFIR post and liner. Sixteen 4-in. sched. -80 fipes are welded to the cask to enhance heat transfer. Elght of these pipes are extended above the cask for er.rgy absorbtion. The internal heat transfer connectors are tinned to enhance bonding for heat transfer purposes. The closure (top) and tine bottom of the cask are protected by impact energy-absorbing structures. The top absorber is a carbon steel ring-shaped plece held in place by 4-3/4-in. bolts and captured by surrounding pipes and gussets. The containment vessel is formed by the cavity wall, the bottom heac?, the lower surface of the shield plug, and the cask gasket. The gasket is a 


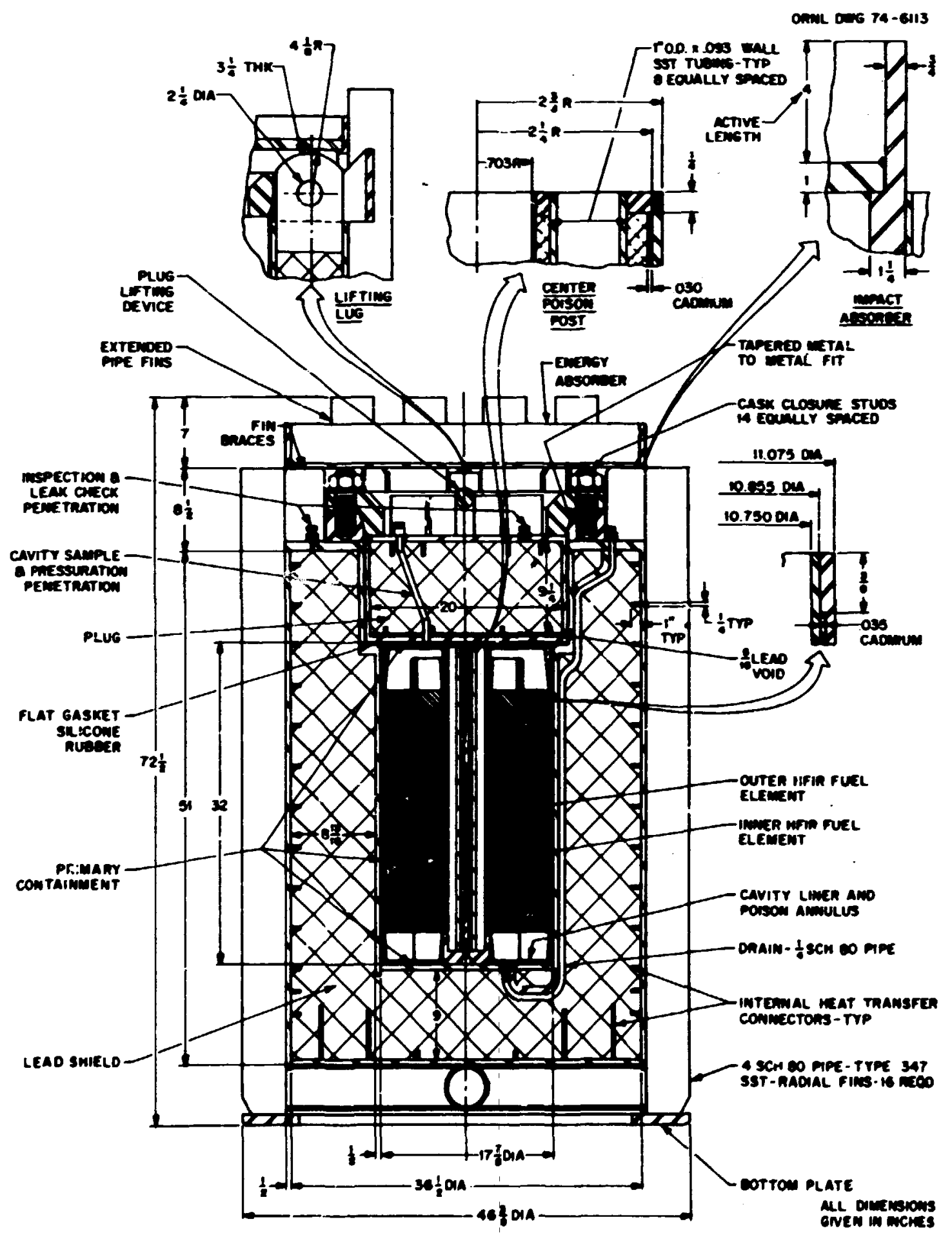

Fig. 0.1. HFIR cask loaded with a complete HFIR core. 
flat sillcone rubber gasket 18-1/2 in. ID by $21 \mathrm{in.} O D$ by $1 / 8 \mathrm{in.} \mathrm{thick.}$ Biological spielding is provided by a nominal lead thickness of $8-3 / 4 \mathrm{in}$. and 1 in. of type 347 stainless steel cladding.

\section{2 .1 Operational features}

The cask is designed for pool loading and unloading. After the cask - is removed fron the pool, water is removed fron the cavity via the drain penetration (Fig. 0.1 ) by introducing air pressure to the cavity sampling and pressurizing penetration in the plug. To ensure that essentially all the water is removed, air is circulated through the loaded cask for a period of 30 win with the vent connected to an off-gas systen. The cask is lifted by two lifting iugs located on top of the cask and a special lifting Jevice (Appendix A, Fig. A.6). The plug is lifted for removal or installation by a single lifting bar located on top of the plug. The cask is designed to be secured to a vehicle bed by bolting the cask base to a base plate, which 18, In turn, bolted to the vehicle frame (Fig. 1.9).

The cask internals are exchangeable to adapt to elther ORR- or HFIR-type elements. For shipment of HPLR elements the poison post and liner (F1g. 0.1 and drawings, Appendix A) are installed. When ORR elements are shipped, the post and liner are reaoved, and the ORR fuel nagazine (Fig. 0.2 and drawings, Appendix A) is installed in their place. Due to geometrical differences in elements, it is not pussible to load elements with the wrong internals in the cask.

\section{2 .2 Contents}

The cask is designed to transport one spent HPIR core consisting of an inner and an outer element as shown In Fig. 0.1. The HFIR elements are show in Fig. 0.3. Detalled drawings of the elewents are included in Appendix $C$, and detailed specifications are contained in ORNL Specifications. 6 The cask design basis was for an HFIR operating cycle ${ }^{2}$ of 15 days at $10 n \mathrm{in}(t)$ followed by a 270-day post-operation decay period. The current cycle 18 about 23 days at $100 \mathrm{w}(t)$ followed by a 240-day postirradiation decay perlod. Conservatism in the design from the standpoint 


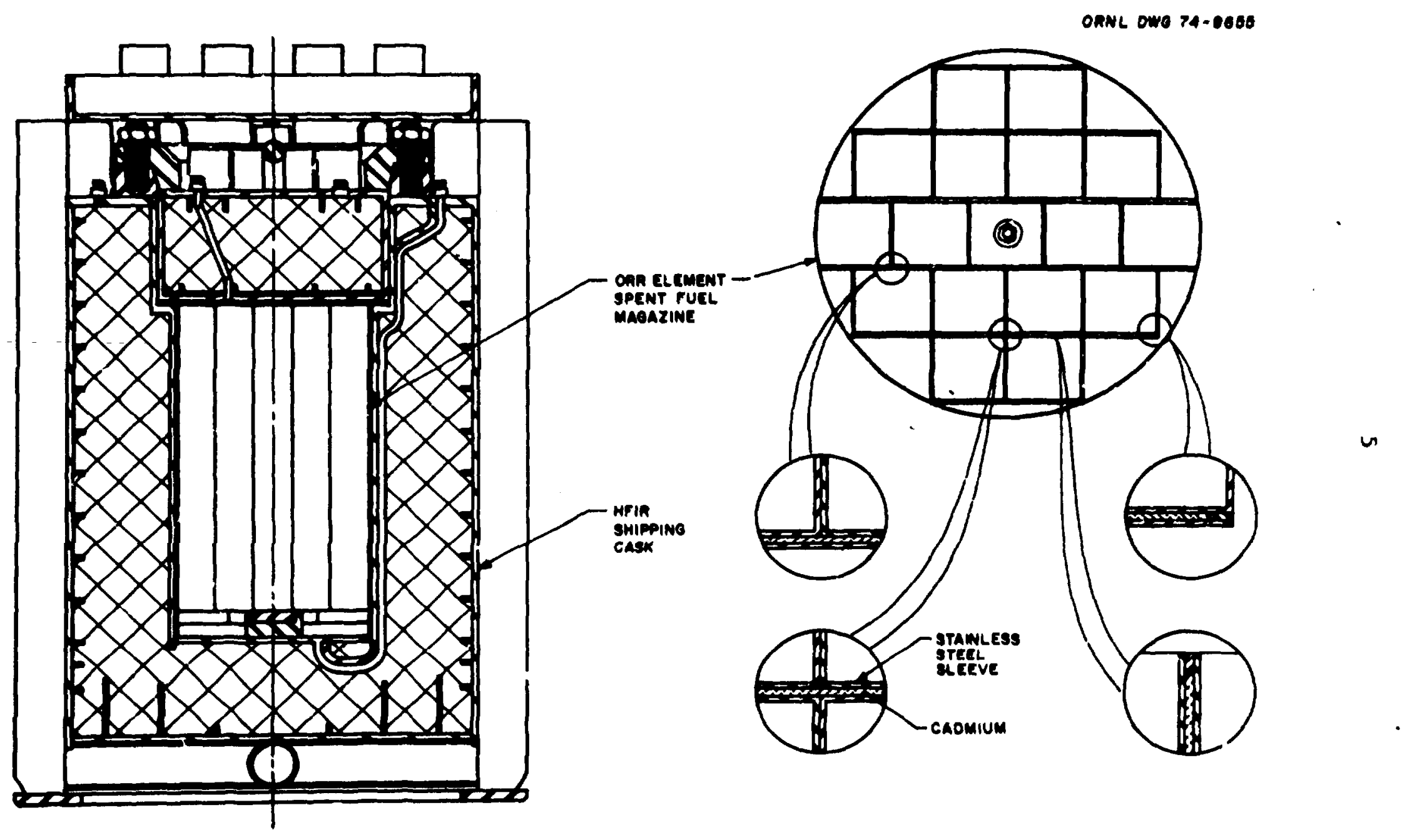

F18. 0.2. HFIR cask with ORR elements loaded. 


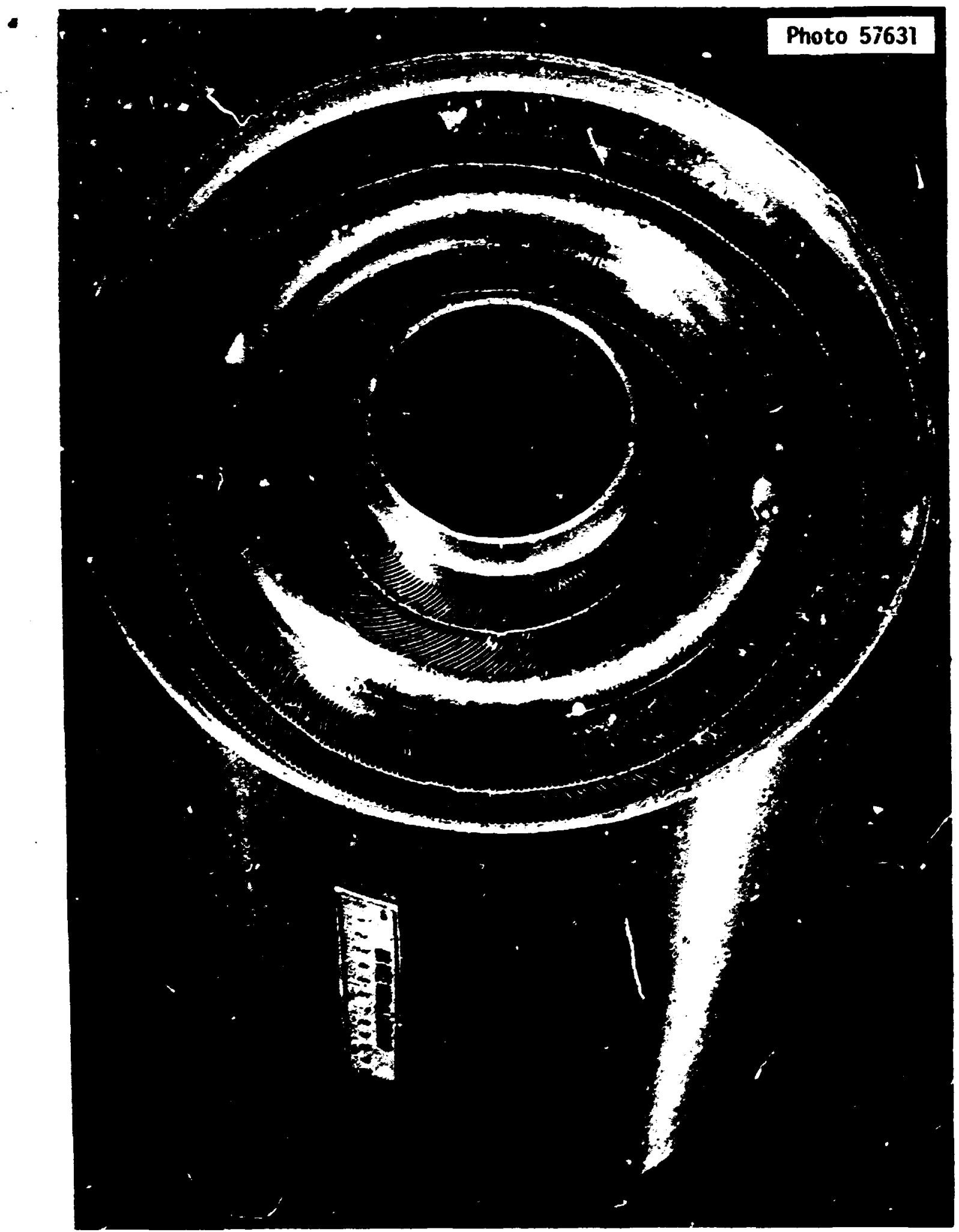

F1g. 0.3. HFIR element. 
of shielding and heat trans:er made shipping of elements from the current operating cycle with a shorter decay period feasible.

The cask has been adapted to transport a maximum of 17 ORR, Bulk Shieiding Reactor (BSR), or Puerto Rico Nucleat Center (PRNC) (MTR Type) spent fuel elements. Typical elements are illustrated in Fig. 0.4, and detailed drawings appear in Appendix $C$. The fuel element end fittings are removed by sawing before shipment.

The operating histories of ORR, BSR, and PRNC eletients vary considerably. The design operating hiscory outlined below offers a conservative basis for evaluating cask performance from the standpoint of heat transfer, shielding, and criticality. The operating cycle has no significant effect on the structural integrity of the cask, except as related tc decay heat disspation. For the purpose of calculating decay heat, the element is assumed to remain in the reactor throughout its life. In reality, the element is cycled in and out of the reactor in various core positions depending on the amount of ${ }^{235} \mathrm{U}$ remaining.

The calculated therual energy release (Appendix D) for the element after the 151)-day decay period, is $210 \mathrm{~W}$ per element or $3570 \mathrm{~W}$ per shipment. The coiservatism of this value is demonstrated in the addendum to Hammick's report in Appendix $\mathrm{C}$. Data femonstrating that PRNC elements have lower heat generation rates are also in Appendix $D$.

The cask will be used infrequently to transport ORNL Tower Shielding Facility (TSF) spent elenents and the ORNL Health Physics Research Reactor (HPRR) spent elements. These elements have significantiy lower heat generation and radiation levels than efther the HFIR, ORR, BSR, or PRNC elements. The TSR II and/or HPRR elements generate a maximum heat load of about $500 \mathrm{~W}$. Hence this load is not signtficant when compared with the heat loads considered in the preceding section. These elements will be loaded in racks or blocked in place so that the movement of elements within the cask is limited to $1 / 2$ in. during shipment.

\section{STRUCTURAL EVALUATION}

The package complies with the structural requirements of the regulations. ${ }^{3-5}$ The calculations, test results, and engineering logic presented in the following sections demonsicrate compliance with these 

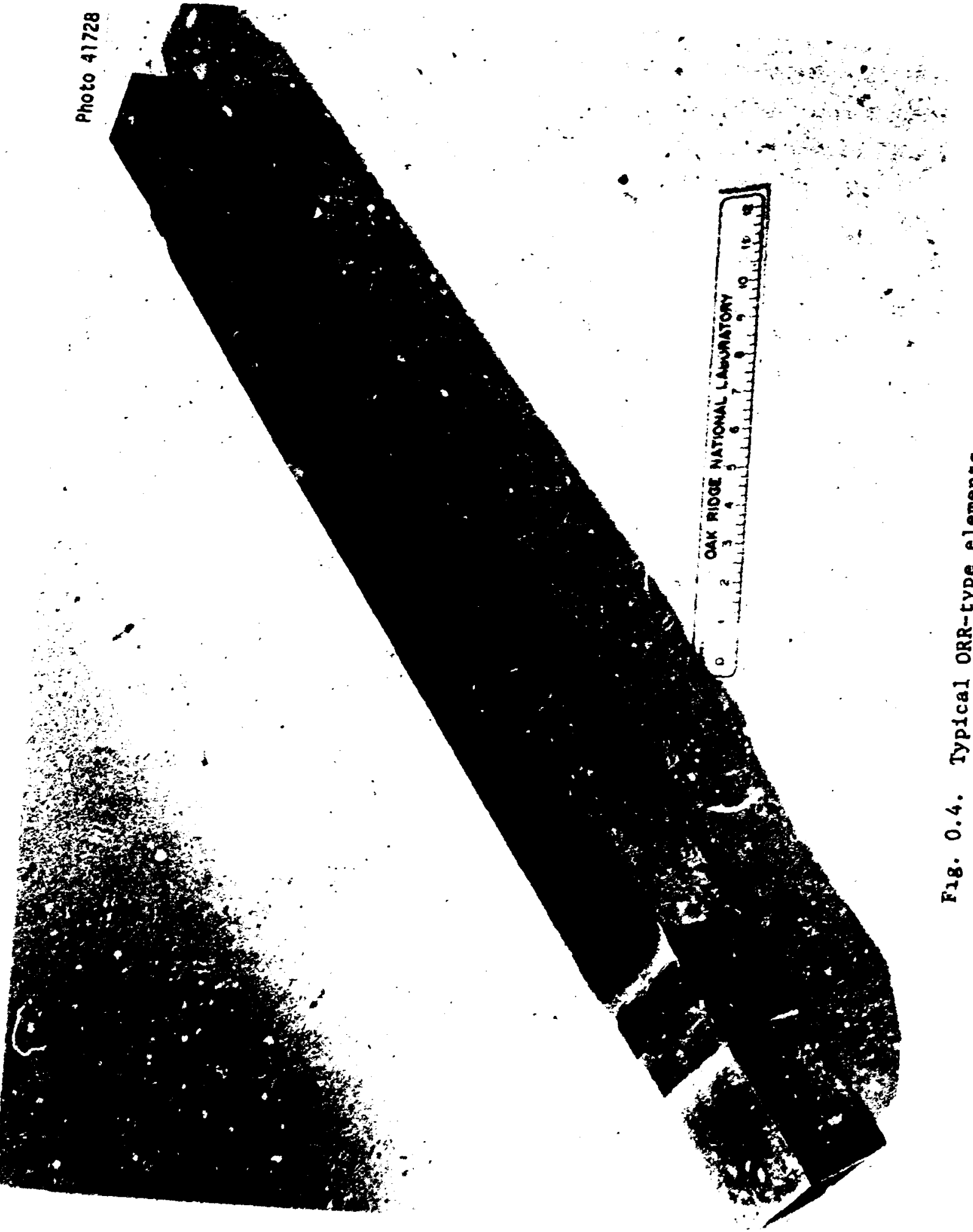

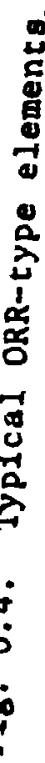


performance criteria. The effects of both normal and specified accident conditions on the structural intagrity of the package are considered.

\subsection{Mechanical Properties of Materials}

The static properties of the materials used in the cast are listed in Table 1.1. The properties of the stainless steel are taken from data published by the International Nickel Company. ${ }^{7}$ The properties of AISC4340 are taken from data published in The Ferrous Metals Book. 8

Table 1.1. Static mechanical properties of cask materials

\begin{tabular}{|c|c|c|c|c|}
\hline Property & Symbol & $\begin{array}{c}304 \mathrm{~L} \\
\text { stainless } \\
\text { steel }\end{array}$ & $\begin{array}{c}\text { AISC4340 } \\
\text { steel }\end{array}$ & $\begin{array}{c}347 \\
\text { stainless } \\
\text { steel }\end{array}$ \\
\hline Yield stress, psi & $\sigma_{y}$ & 30,000 & 109,060 & 30,000 \\
\hline $\begin{array}{l}\text { Ultimate tensile } \\
\text { strength, psi }\end{array}$ & $\sigma_{\mathbf{u}}$ & 75,000 & 109,000 & 75,000 \\
\hline $\begin{array}{l}\text { Modulus of elasticity, } \\
\text { psi }\end{array}$ & $\mathbf{E}$ & $29 \times 10^{6}$ & $30 \times 10^{6}$ & $29 \times 10^{6}$ \\
\hline Elongation, $z$ & & 40.0 & 22.0 & 40.0 \\
\hline Density, $1 \mathrm{~b} \cdot$ in. $^{3}$ & p & 0.283 & 0.283 & 0.283 \\
\hline $\begin{array}{l}\text { Maximum alloweble } \\
\text { shear }=\sigma_{y} / 2, \text { psi }\end{array}$ & $\tau_{\max }$ & 15,000 & 54,500 & 15,000 \\
\hline $\begin{array}{l}\text { Coefficient of expansion, } \\
\text { in./in. }{ }^{\circ} \mathrm{F}\end{array}$ & $a$ & & $9.2 \times 10^{-0}$ & $9.2 \times 10^{-6}$ \\
\hline Ultirate shear stress & Tult & & 61,000 & 53,000 \\
\hline
\end{tabular}

The volumetric expansion properties of lead as reported by Shappert 10 are used to evaluate the effects of thermal gradients. Figure 1.1 is reproduced from Shapperi's report.

The programs used to estimate the response of the cask 1mpacting on the corner and side are based on the assumption that the cask is constructed of 1deally plastic materials. An ideally flastic material is a material which has a constant ralue of stress for all strains. It 18 recognized that normally used cas'k materlals do not behave in this manner. However, conservative solution 3 can be effected if care is used in selecting the 


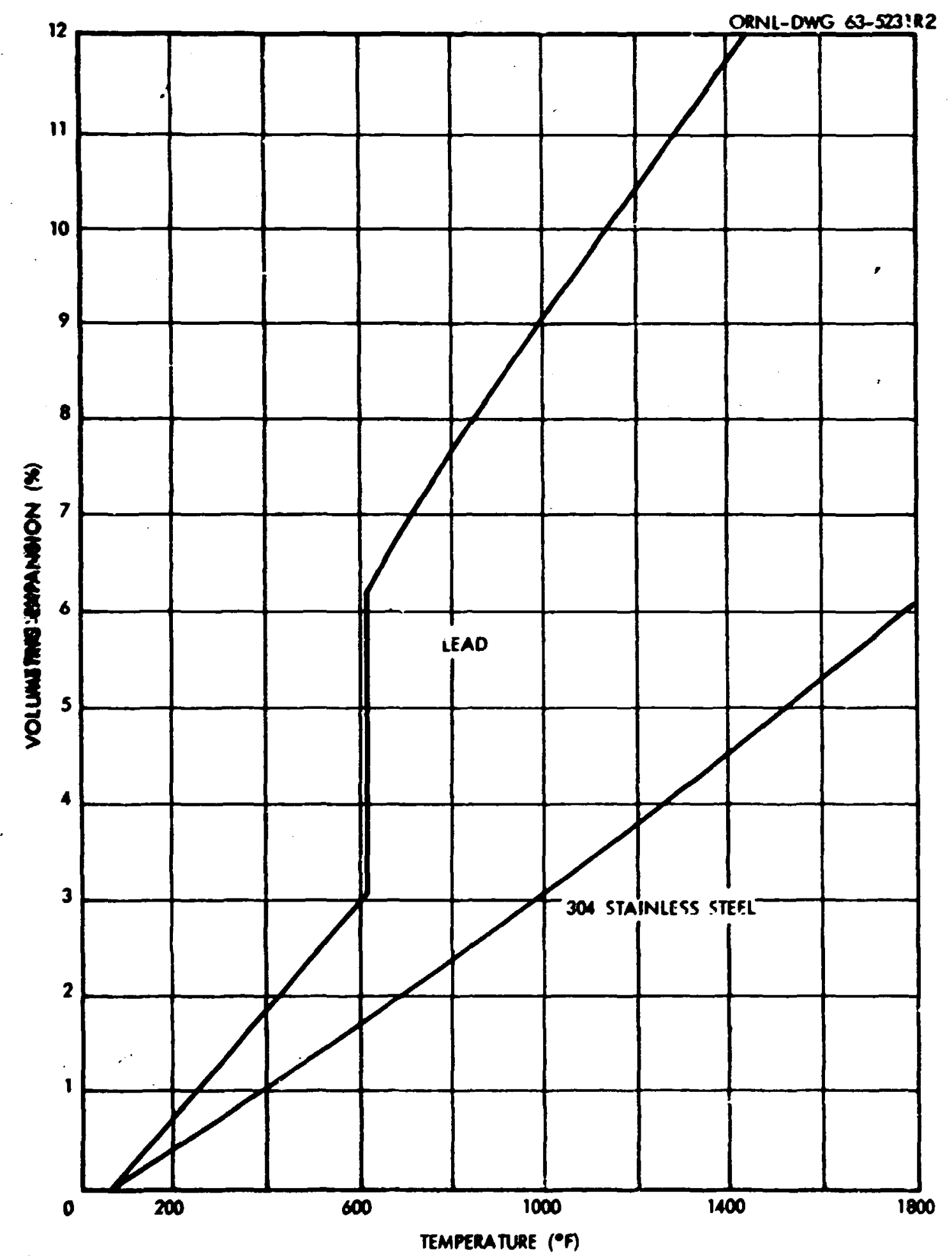

F1g. 1.1. Volumetric expansion of lead and stainless steel as a function of temperature. 
material property constant, dynamic yield stress or spectfic e:sergy, and in interpreting the results. To accouplish this objective numerical values for ideal dynawic yield stress or specific energy which bound the real stress-strain curve must be selected. The lower value will result in a calculated deformation which is greater than actual. The higher value will result in calculated accelerations of greater magnitude than actual. It can then be seen from Fig. 1.2 that the selected values of 6000 psi and 14,000 psi for the dynamic compressive yield stress for lead will effect a conservative solution for a lead-shielded cask. This figure is the result of experimental data obtained by Evans. 9

The dynamic tensile properties of stainless steel reported by Clark ${ }^{1}$ (Fig. 1.3) and the dynamic compressive properties of steel and stainless steel reported by the author ${ }^{12}$ (F.Ig. 1.4) were used in the impact analyses. For gross deformations, the curves support the selection of 100,000 and 240,000 psi as limits for dynamic compressive yield-stress for stainless steel for thoed techniques employing this concept. In all impact analyses it is assumed that steel, stainless steel, and lead are incompressible.

\subsection{General Standards for All Packages}

The general standards for all packaging cover the chemical and galvanic reactions of the materials of the package, closure of the package, and the lifting and tie-down devices for the package. As shown in the as-built drawings, the containers are constructed of type 347 and $304 \mathrm{~L}$ stainless stecl and chemical lead (ASTMB29, 99.97 lead minimum). There has been no evidence of any significant chemical, galvanic, or other reaction between these materials, nor has there been any experience of reaction between these materials of construction and the intendeJ package contents.

\subsection{1 closure}

The cask is equipped with a positive closure consisting of fourteen 1-1/2-in.-diam studs which secure the 11d and prevent lnadvertent opening of the cask. Additionally, a seal wire is applied through a drilled hole in one stud so that any tampering with the closure will be revealed. 


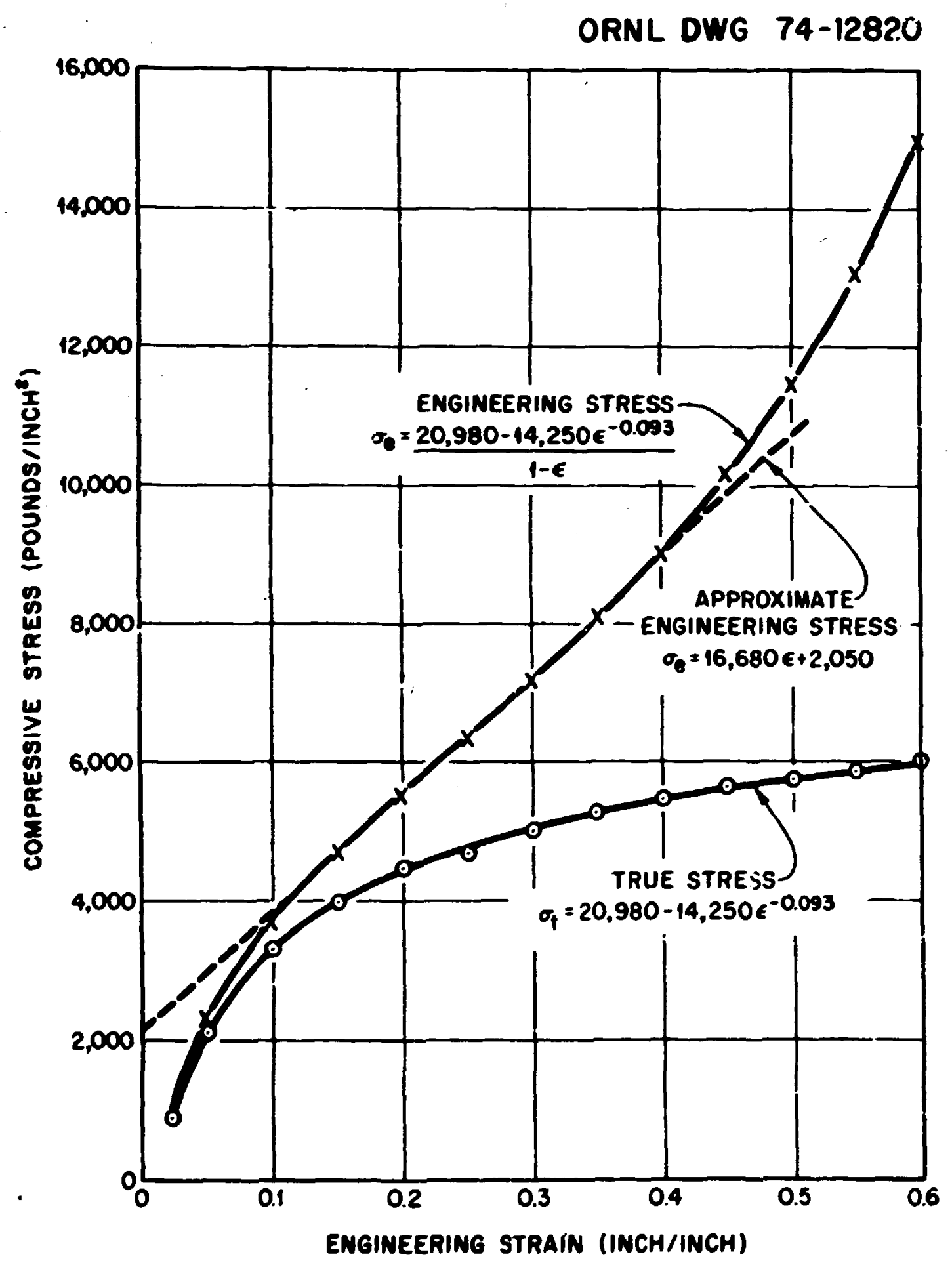

P18. 1.2. Dynamic compressive stress-strain diagran for lead. 
ORNL DNG NO. 11-13027

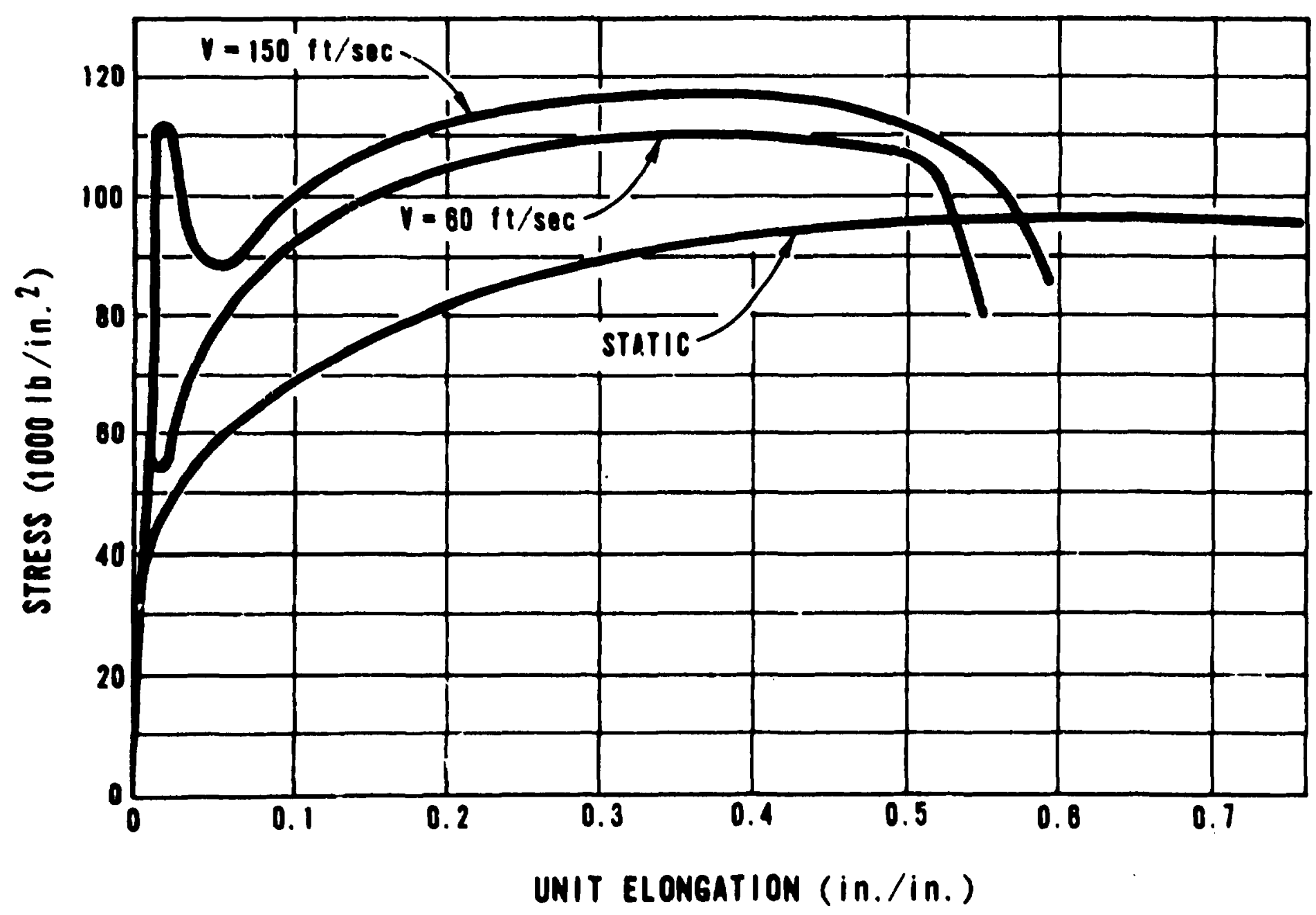

Fig. 1.3. Dynamic tensile stress-strain curves for 18-8 stainless steel. 


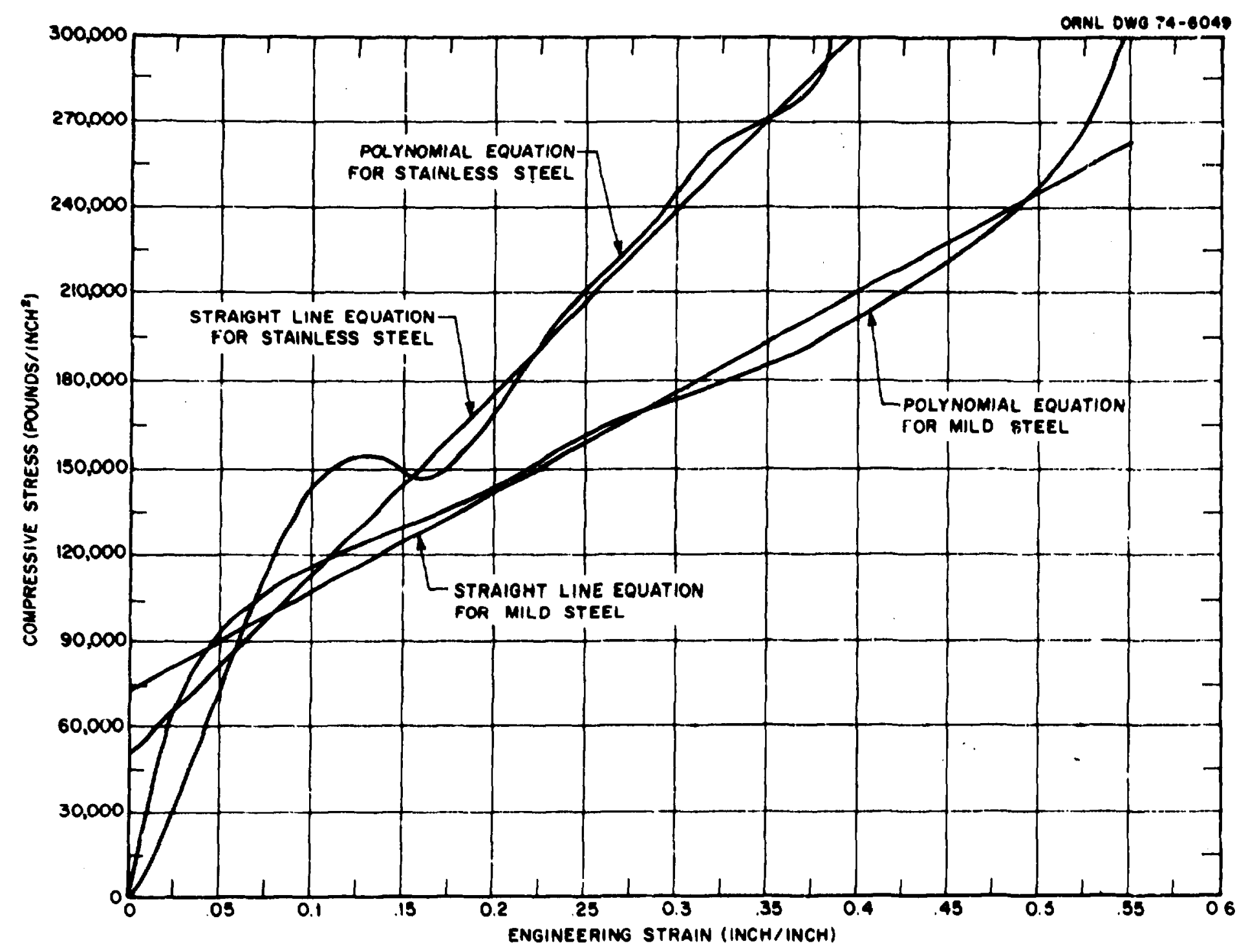

F1g. 1.4. Dynamic compressive stress-8train curves. 


\subsubsection{Cask-1ifting devices}

If there is a system of lifting devices that is a structurai part of the package, the regulations require that this systen be capable of supporting three times the weight of the loaded package without generating stress in any material of the package in excess of its yield strength.

The cask is designed to be lifted by two lugs located on the top of the cask (Fig. 0.1). The lug design is such that a special lifting sling is required (Appendix A, Fig. A.6). This sling ensures that the lcads are applied axially to the lug.

The dimensions of the liftirg lug are shown in Fig. 1.5. The load is $P=(3)$ (weight of cask) $=(3)(23,000)=69,000 \mathrm{lb}$ or $34,500 \mathrm{lb} / \mathrm{lug}$.

The allowable stress $=30,000$ psi, which is the yield stress of type 347 stainless steel.

\subsubsection{Average tensile stress in lifting lug at section A-A of}

Fig. 1.5 .

$$
\sigma_{\mathrm{av}}=\mathrm{P} / \mathrm{A}=34,500 /(4.969)(3.25)=2.40 \mathrm{psi}
$$

1.2.2.2 Shear stress in pin (double shear). The shear stress $\tau$ in the pin is

$$
\tau=\mathrm{P} / 2 \mathrm{~A}=\mathrm{F} / 2\left(\pi \mathrm{d}^{2} / 4\right)=(34,500) /(2)(\pi / 4)(2.25)^{2}=4350 \mathrm{psi},
$$

where $d=$ diameter of pin (in.).

The limiting stress $=0.5 \mathrm{~s}_{\mathrm{yp}}=15,000 \mathrm{ps} 1$.

1.2.2.3 Bearing stress in the lug. The bearing stress $\sigma$ in the 1 ug is

$\sigma=\mathrm{P} / \mathrm{A}$, 

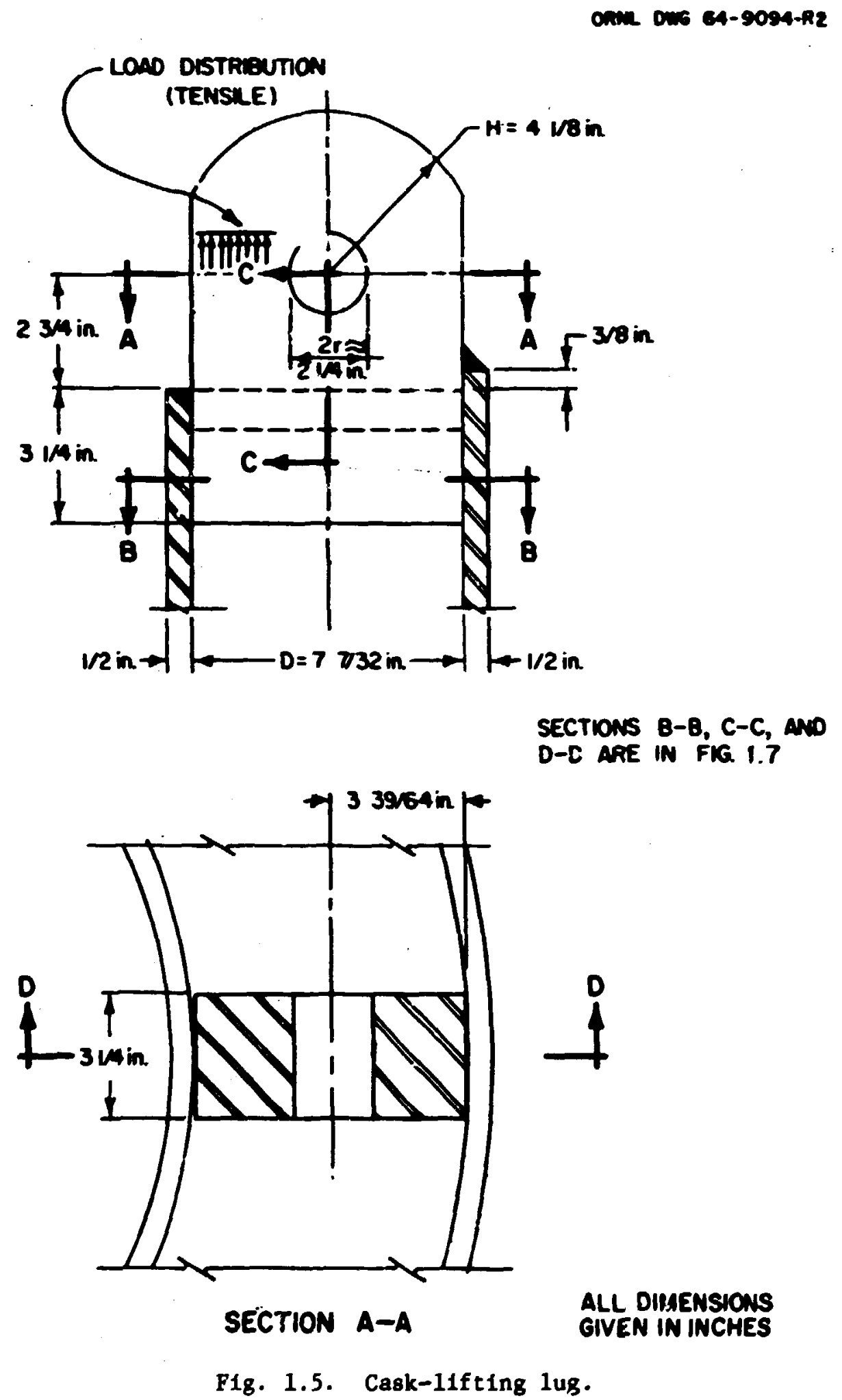
where $A=$ cross-sectional area of lifting lug eye (in.),

$$
\sigma=34,500 /(3.25)(2.25)=4718 \text { psia }
$$

1.2.2.4 Shear stress in welds that attach lifting lugs to cask. As shown in Fig. 1.6, the weld-shear area $A$ for the welds that attach the lifting lugs to the cask are given below:

$$
\begin{aligned}
\text { Section } B-B: A=(2)(1.0)(3.25)+(2)(1.0)(3.625) & =13.750 \text { in. } 2 \\
\text { Section C-C: } A=(2)(1 ;(7.219) & =14.438 \\
\text { Seclition D-D: } A=(2)(0.5)(3.25) & =\frac{3.25}{\text { Total weld-shear area }}=31.438 \text { in. } 2
\end{aligned}
$$

The average weld shear stress is

$$
\tau=\mathrm{P} / \mathrm{A}_{\mathrm{T}}=34,500 / 31.438=1100 \mathrm{ps} 1 .
$$

All normal stresses in the cask-lifting device are less than the yield stress of 30,000 psi for type 347 stainless steel, and all shear stresses are below the allowable of 15,000 psi; therefore, the device exceeds the requirements of the regulations.

\subsection{3 lid-lifting devices}

The regulations require that if there is a system of $11 \mathrm{fting}$ devices that is a structural part of the lid only, this system shall be capable of supporting three times the weight of the $11 \mathrm{~d}$ and any attachment without generating stress in any material of the lid in excess of its yield strength. It is further required that unless rendered useless for lifting during transport of the package, the 11d-11fting system or any other system of lifting devices shall conform to the requirements for the packagelifting system. The lid-iffing device is covered during transit, rendering it unavallable for lifting; thus, it is exempt from this requirement. 

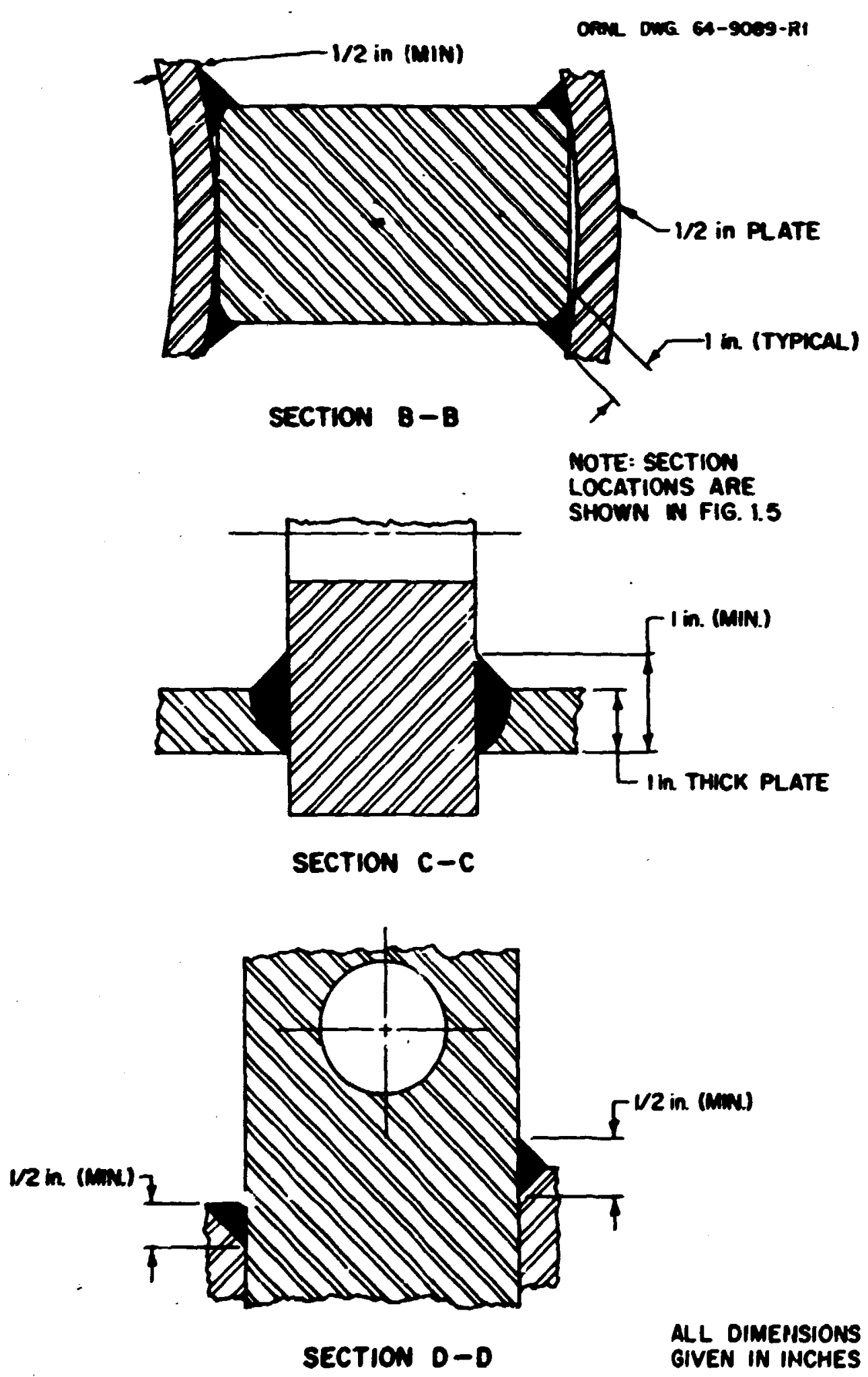

F1g. 1.6. Lifting-iug sections. 
The lid-1ifting lug is illustrated in Fig. 1.7. The design load is

$$
P=3(\text { weight of 1id) }=3(2100)=6300 \mathrm{~b} .
$$

The allowable stress $=$ yield stress of type 347 stainless stee $1=$ 30,000 psi.

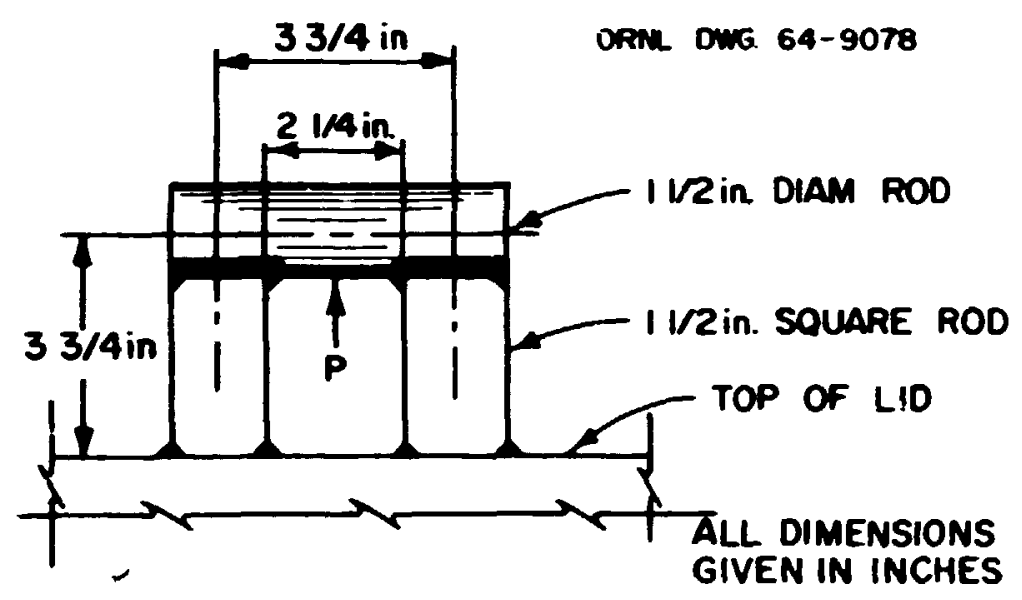

Fig. 1.7. Lici-lifting lug.

The 1-1/2-in. square rods are actually stiffened by the fins on the 1id. Thus the 1-1/2-in. round rod acts almost as if it were a beam with fixed ends and as if the length of that beam wert only the clear span between the square rods. However, the calculations will be based on a far more conservative basis wherein the weldment of three rods is taken as a rectangular frame with fixed ends. Then, using formulas published by Product Engineering, 31

$$
M_{\text {base }}=P L / 8 D \text {, }
$$

where

$$
\begin{aligned}
& D=2+\left(I_{0} / I_{s q}\right)(h / L), \\
& I_{0}=\pi d^{4} / 64=\pi(1.5)^{4} / 64=0.249,
\end{aligned}
$$




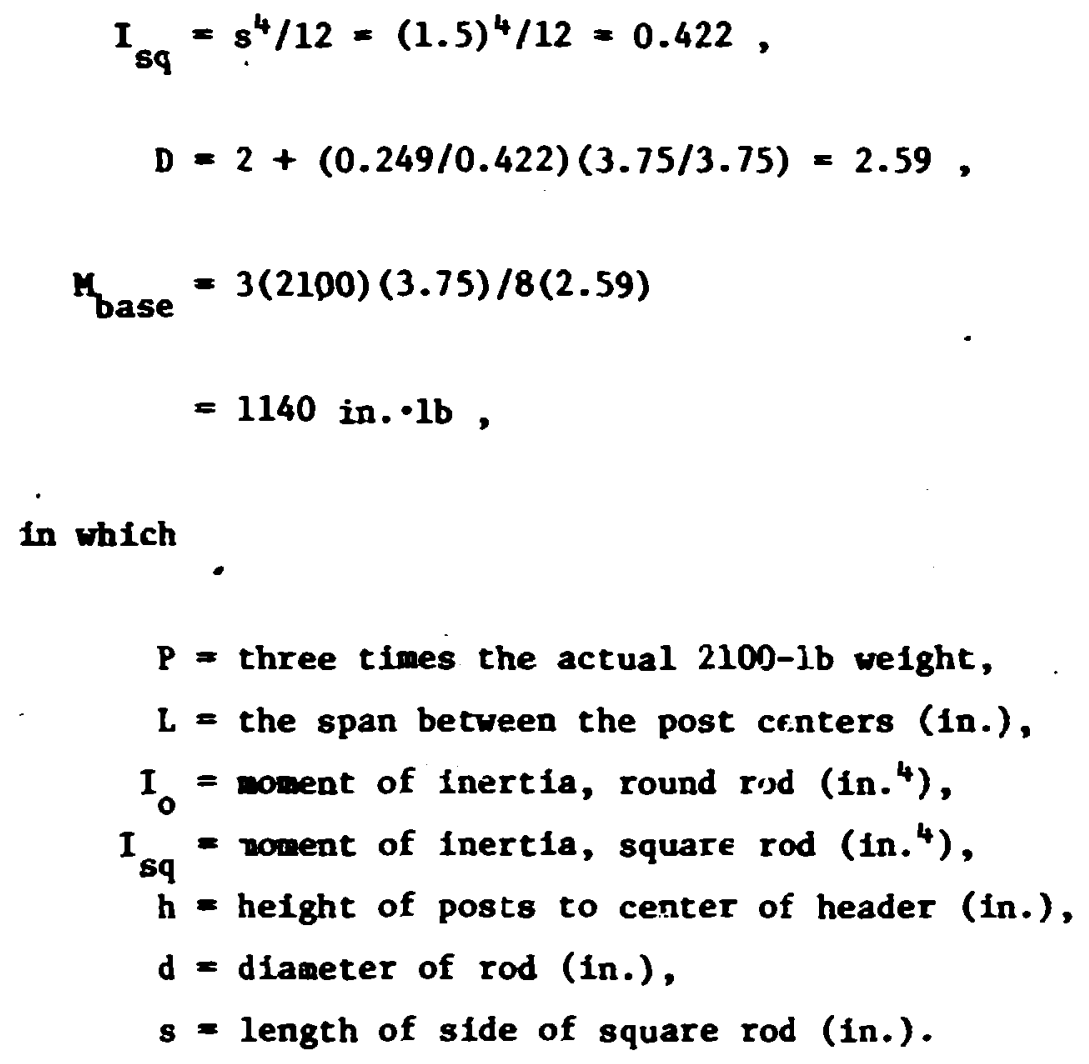

In which

$$
\begin{aligned}
P & =\text { three times the actual } 2100-1 b \text { weight, } \\
L & =\text { the span between the post centers (in.), } \\
I_{0} & =\text { moment of inertia, round rod }\left(i n .{ }^{4}\right), \\
I_{s q} & =\text { noment of inertia, square } \operatorname{rod}\left(i n .{ }^{4}\right), \\
h & =\text { height of posts to center of header (in.), } \\
d & =\text { diameter of rod (in.), } \\
s & =\text { length of side of square } \operatorname{rod}(\text { in.). }
\end{aligned}
$$$$
I_{s q}=\text { noment of inertia, square } \operatorname{rod}\left(1 n .{ }^{4}\right) \text {, }
$$

The tensile stress must be added to find the total stress:

$$
\begin{aligned}
\text { total stress at base } & =\mathrm{P} / \mathrm{A}+\text { bending stress } \\
& =3(2100) / 1.5(1.5)+1140(0.75) / I_{\text {sq }} \\
& =2800+1140(0.75) / 0.422 \\
& =4830 \mathrm{psi}
\end{aligned}
$$

At the junction of a post and the square rod, the bending stress is twice as great, so the total is

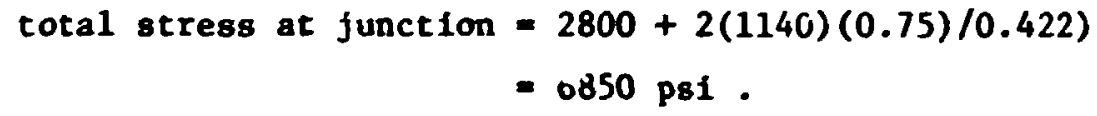

The bending stress in the round rod, a maxt at the central load, is 


$$
\begin{aligned}
S & =M / Z=2 M_{b} /\left(\pi d^{3} / 32\right) \\
& =2(1140) /\left[\pi(1.5)^{3} / 32\right] \\
& =6890 \mathrm{psi},
\end{aligned}
$$

where $2 y_{b}=$ moment at the end $(1 b \cdot i n$.$) .$

Since the resulting stresses, determined by a conservative technique, in the lid-lifting lug are less than the yield point stress for type 347 stainless steel, the cask exceeds the requirements of the regulations.

\subsubsection{Tie-down devices}

If a systen of tie-down devices is a structural part of the package, the regulations require that this system be capable of withstanding a static force applied to the center of gravity of the package with a vertical component of two times the weight of the package and its contents, a horizontal component in the direction of travel of ten times the weight of the package and its contents, and a horizontal component in the transverse direction of five times the weight of the package and its contents. This applied force shall not generate stresses in any material of the package in excess of the yield strength of that material. It is also required that any tie-down device that is a structural part of the package shall be so designed that fallure of the device under excessive load will not impair the ability of the package to meet other requirements of the regulations. The cask is designed to be bilted directly to the bed of a transport vehicle as shown in Fig. 1.8. Calculations demonstrating the adequacy of the cask for this configuration follow.

1.2.4.1 Bolted cask tie-down. The cask is secured by bolting the cask base plate to the truck or rail car bed using s: xteen $1-1 / 2-1$. .diam bolts as shown in Fig. 1.8. Alternatively, the cask can be attached to a special purpose plate which is bolted to the truck bed. 
ORNL DWG. 64-9070

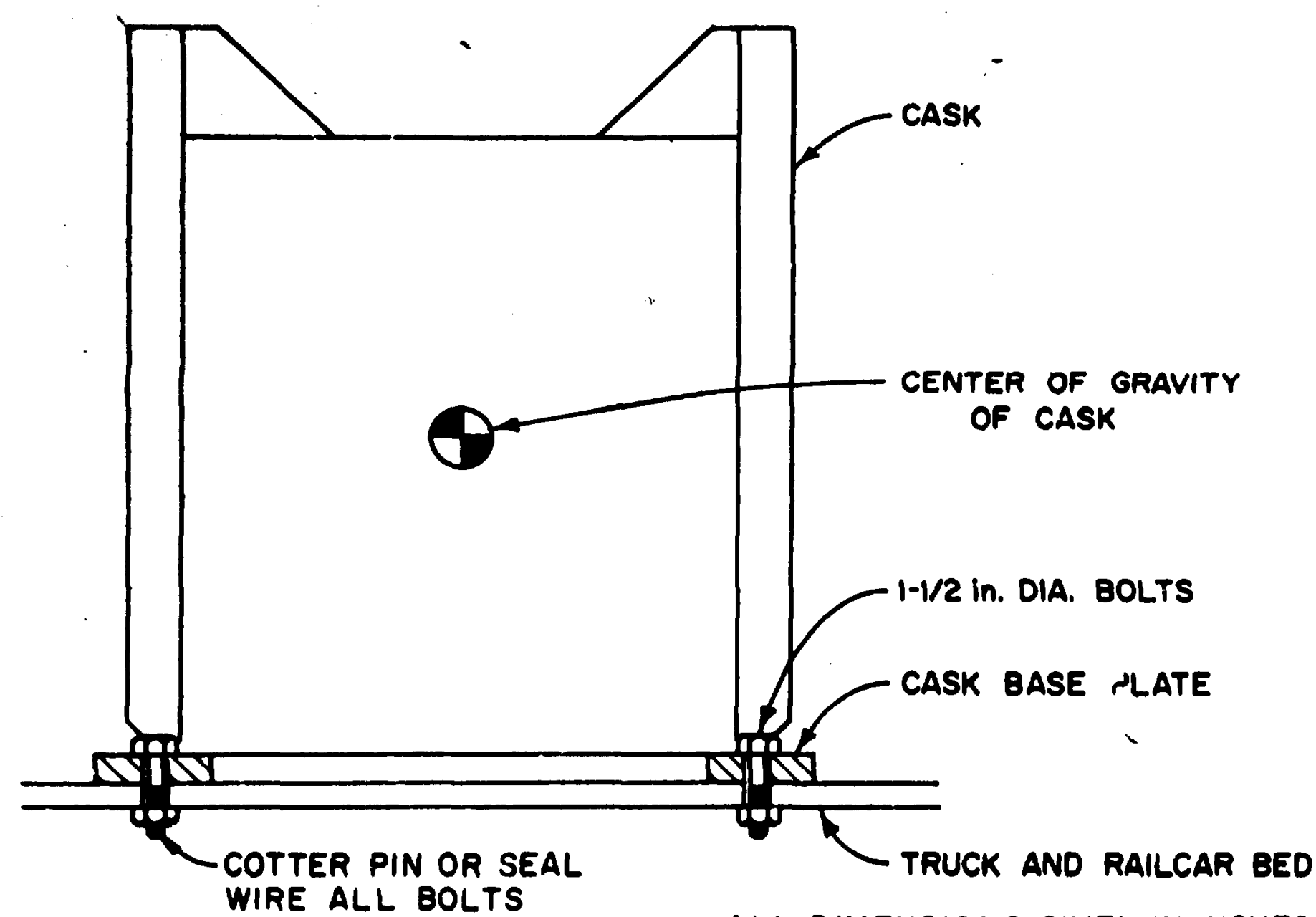

N

ALL DIMENSIONS GIVEN IN INCHES

F18. 1.8. Bolted cask tle-down (d1rect to truck bed). 


\subsubsection{Determination of stress in bolts for vertical load of two} times weight of cask.

$$
\boldsymbol{\sigma}=\mathbf{P} / \mathbf{A},
$$

where

$$
\begin{aligned}
& P=10 a d=2(23,000)=46,0001 b \\
& A=\text { tensile stress area }{ }^{13} \text { of } 16 \text { bolts }=16(1.405)=22.48 \text { in. }^{2}
\end{aligned}
$$

Therefore the stress is

$$
\sigma=46,000 / 22 \cdot 48=2050 \mathrm{psi} \text {. }
$$

1.2.4.3 Determination of stress in bolts for horizontal components of ten times and five times weight of cask. For a horizontal load, the bolts are subjected to two stresses: a shear stress and a tensile stress. By summation of moments about A (Fig. 1.9), the maximum force in a bolt can be determined by the technique published by Berger ${ }^{14}$ below. In the interest of calculational simplicity and conservatism, the line of action of the resultant of the horizontal load is assumed to be in line with a bolt.

This force is

$$
\begin{aligned}
a & =L / D=2 / 42=0.047619 \\
k_{3} & =(1+a) /\left(0.375+a+a^{2}\right)=1.047619 /(0.375+0.047619+0.002268) \\
& =2.4656 \\
M & =(32.75)(257,140)=8.421,0001 b \cdot 1 \mathrm{n} . \\
f_{h} & =\left(k_{3} / D N\right)(M)=2.4656\left(8.421 \times 10^{6}\right) /(42)(16)=30.9001 b,
\end{aligned}
$$




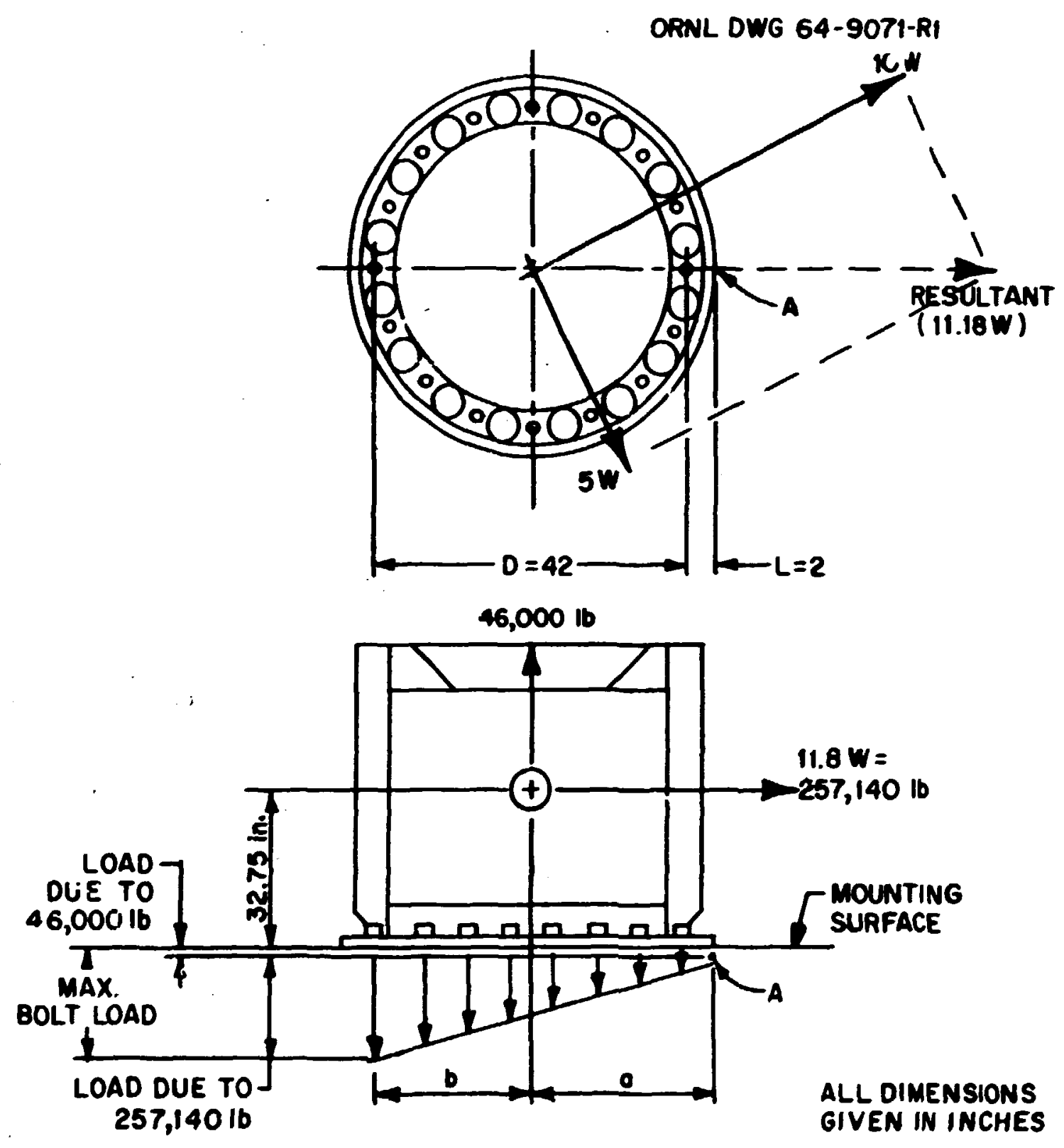

F1g. 1.9. Porce diagram. 
where

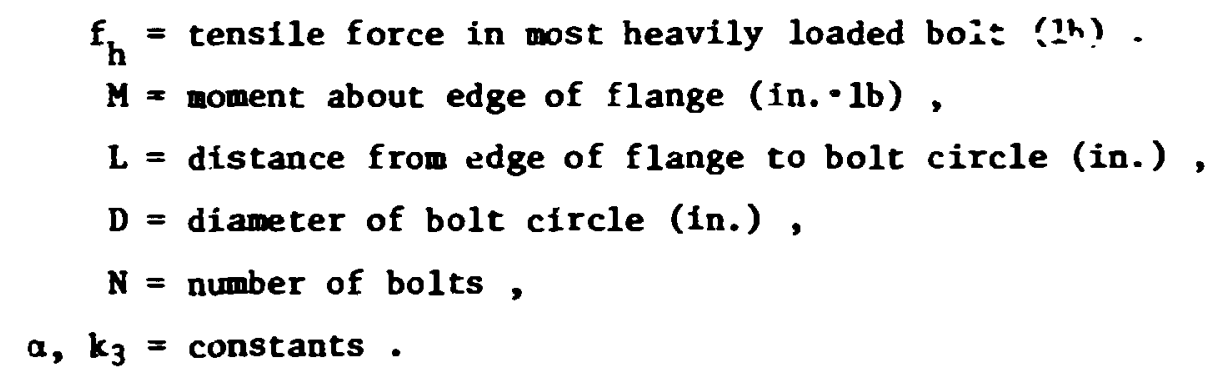

The resulting tensile stress is

$$
\sigma_{B}=F_{\max } / A=30,900 / 1.405=22,000 \mathrm{ps} 1 \text {, }
$$

where $A=$ tensile stress area $^{13}$ per $1-1 / 2$ 6UNC bolt $\left(\right.$ in. ${ }^{2}$ ).

The shear stress per bolt is

$$
\begin{aligned}
\tau & =P / A=257,140 / N\left(\pi d^{2} / 4\right)=4(257,140) /(16)(\pi)(1.5)^{2} \\
& =9.090 \mathrm{psi} .
\end{aligned}
$$

1.2.4.4 Determination of stress with all loadings combined. The maximuan tensile stress $\sigma_{T}=\sigma_{a}+\sigma_{B}=2050+22,000=24,050$ psi. From Mohr's circle of stress, the maximum principle stress is

$$
\begin{aligned}
& \left.\sigma 0.5 \sigma_{T}+\left[\left(0.5 \sigma_{T}\right)^{2}+\tau^{2}\right)\right]^{1 / 2} \\
& =12,025+\left[(12,025)^{2}+\left(9090^{2}\right)\right]^{1 / 2}=27,100 \mathrm{psi} .
\end{aligned}
$$

Thus the bolted system exceeds the requirements of the regulations since the bolis are of a material having a yield stress in excess of this. 


\subsection{Compliance with Structural Standards for Packaging}

The structural standards for large-quantity packaging cover load resistance of the packaging and the external pressure which the package wst withstand. Compliance of the BPIR cask with these requirewents is discussed in the following subsections.

\subsubsection{Load resistance}

When regarded as a simple bean supported at its ends along any major axis, the package wast be capable of withstanding a static load normal to and unifornly distributed along its length that is equal to five tines its fully loaded weight without generating stress in any material of the cask in excess of the yield strength of that material.

1.3.1.1 Determination of bending stress. Assume that the lead has no resistance to bending. The bending stress $\sigma_{b}$ is calculated from the veli-known expression

$$
\sigma_{b}=M c / I \text {, }
$$

where

$$
\begin{aligned}
& M \text { - maximu bending moment (in. } \cdot 1 b), \\
& c=\text { distance from neutral axis to outermost fiber (in.), } \\
& I=\text { moment of inertia of section }\left(1 n .{ }^{4}\right) .
\end{aligned}
$$

For determination of the moment of inertia of the outer she1l and sixteen 4-in. sched. -80 pipes equally spaced around the outer shell as shown in Fig. 1.10,

$I_{c}=$ moment of Inertia of composite element (in. ${ }^{4}$ ),

$I_{s}=$ moment of inertia of outer shell (in. $\left.{ }^{4}\right)$,

$I_{p}=$ moment of inertia of a 4-in. sched. -80 pipe (in. ${ }^{4}$ ),

$A_{p}-$ area of 4-in. sched. -80 pipes $\left(i n .{ }^{2}\right)$,

$y=$ distance from the center line of pipe. 


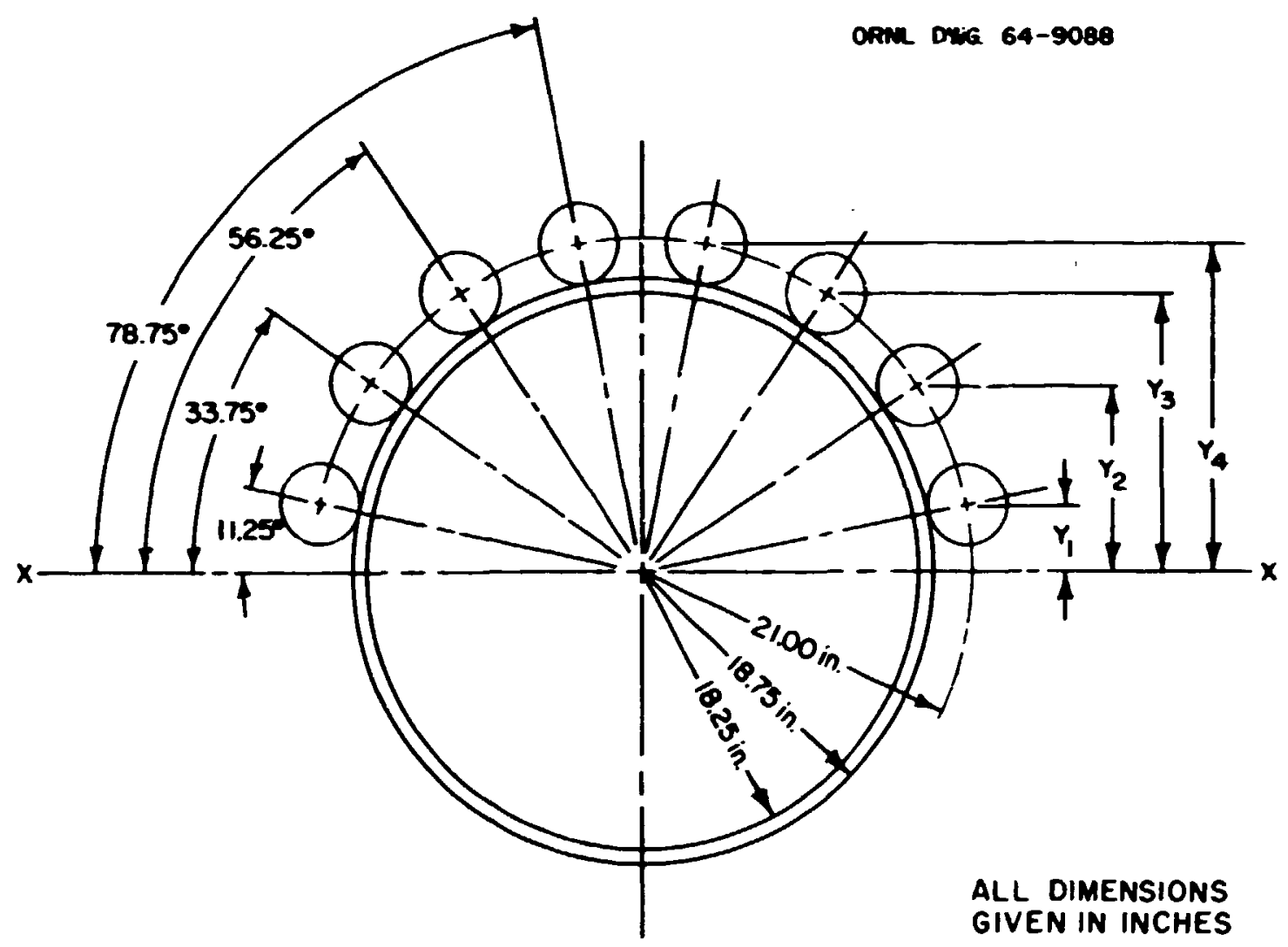

Fig. 1.10. Arrangement of pipes around outer shell. 
All I's are taken about axis $X-X$. Therefore,

$$
I_{c}=I_{s}+16 I_{p}+4 A\left(A^{2}+y_{2}^{2}+y_{3}^{2}+y_{4}^{2}\right)
$$

where the following values are used:

$$
\begin{aligned}
& y_{1}=21 \sin 11.25=4.1 \quad y_{1}^{2}=16.8 \\
& y_{2}=21 \sin 33.75=11.7 \quad y_{2}^{2}=136.1 \\
& y_{3}=21 \sin 55.25=17.5 \quad y_{3}^{2}=304.9 \\
& y_{4}=21 \sin 78.75=20.6 \quad y_{4}^{2}=\underline{424.2} \\
& y_{1}^{2}=y_{2}^{2}=y_{3}^{2}=y_{4}^{2}=\quad \mathbf{8 8 2 . 0} . \\
& I_{s}=\pi / 4\left(R_{d}^{4}-R_{i}^{4}\right)=\pi / 4\left(18.75^{4}-18.25^{4}\right)=9950 \pm n_{0}^{4}, \\
& I_{p}=9.61 \mathrm{in.}^{4} \text {, } \\
& A_{p}=4.407 \text { in. }^{2} \text {, } \\
& I_{c}=9950+16(9.61)+4(4.407)(16.8+136.1+304.9+424.2) \\
& =25,650 \text { in. }{ }^{4} \text {. }
\end{aligned}
$$

The maximum bending moment $M_{\max }$ occurs at the midpoint of the cask and is

$$
\begin{aligned}
M_{\max } & =H L / 8=115,000(72.5) / 8 \\
& =1.042 \times 10^{6} \text { 1n. } \cdot 1 \mathrm{~b},
\end{aligned}
$$

where

$$
\begin{aligned}
& W=\text { five times cask weight (1b), } \\
& L=\text { the cask length (in.). }
\end{aligned}
$$

For distance c,

$$
c=y_{4}+\text { pipe radius }=20.6+2.2=22.8 \mathrm{in} \text {. }
$$

The maximum bending stress $\sigma_{b}$ is 


$$
\sigma_{b}=1.042 \times 10^{6}(22.8) / 25,650=930 \mathrm{psi} .
$$

Because this stress is small when compared with the yield stress, the cask therefore complies with the requirements of the regulations governing the load resistance of packaging. It can be seen by inspection that other radial orientations will result in stresses of the same magnitude.

\subsubsection{External pressure}

The regulations require that the shipping fackage be adequate to ensure that the containment vessel will suffer no loss of contents if subjected to an external pressure of 25 psig.

A potential consequence of the application of external pressure is buckling of the cylindrical shells of the shipping container. For calculational purposes, the portions of the container within the containment vessel (secondary) were assumed to be at atmospheric pressure. Simpiified models of the outer container were used to obtain a conservative evaluation. These wodels consist of a right circular cylinder with closed erds.

The critical (buckling) pressure for this container can be decermined by using equa:tions presented by Faupel. 15 For axisymetric (bellows-type) buckling, the critical pressure $p_{Y}$ is given by the following equation:

$$
P_{r}=2 E(t / r)^{2} /\left[3\left(1-\mu^{2}\right)\right]^{1 / 2} \text {, }
$$

where

$$
\begin{aligned}
& E=\text { modulus of elasticity }=29 \times 10^{6} \mathrm{psi}, \\
& t=\text { thickness of cylinder wall }, \\
& r=\text { radius of cylinder }, \\
& \mu=\text { Poisson's ratio }=0.3 .
\end{aligned}
$$

The critical pressure $p_{r}$ for lobular buckling is given by the equation 15

$$
P_{r}=\left[\frac{1.345 E}{\left(1-\mu^{2}\right)^{3 / 4}}\right]\left[\frac{(t / r)^{5 / 2}}{1.57(L / R)-(t / r)^{1 / 2}}\right],
$$


where $L=$ the length of the cylinder.

The critical pressure $p_{r}$ for hoop stress is given by the equation

$$
P_{r}=s t / r
$$

where

$$
\begin{aligned}
& s=\text { yield stress } \\
& r=\text { cylinder radius, } \\
& t=\text { cylinder thickness } .
\end{aligned}
$$

The 'model for the cask body has a radius of 18.75 in., a thickness of $0.5 \mathrm{in.}$, and a length of $S 2 \mathrm{in.}$ For axisywetric buckling,

$$
P_{\underline{I}}=2(29) \times 10^{6}(0.5 / 18.75)^{2} /\left[3\left(1-0.3^{2}\right)\right]^{1 / 2}=25,000 \mathrm{psi}
$$

For lobuiar buckling,

$$
\begin{aligned}
P_{\mathbf{r}} & =\left[\frac{1.345\left(29 \times 10^{6}\right)}{\left(1-0.3^{2}\right)^{3 / 4}}\right]\left[\frac{(0.5 / 18.75)^{5 / 2}}{1.57(52 / 18.75)-0.5 / 18.75) 1 / 2}\right] \\
& =1,160 \mathrm{psi} .
\end{aligned}
$$

For hoop stress,

$$
P_{Y}=30,000(0.5) / 18.75=800 \mathrm{psi}
$$

The model for the plug has a radius or 10.5 in., a thickness of 0.5 in., and a length of $10.25 \mathrm{in.;}$ the plug, therefore, by Inspection has a higher buckling pressurc than the calculated values for the body.

The flat heads of the cask are braced by external and/or internal heat-transfer fins or surfaces. These situalions are not readily calculable; thus, the conservative approach, which neglects the contributions of the bracing, will be taken. The bottom head is the most vulnerable and has a radius of $18.75 \mathrm{in}$. and a thickness of $0.5 \mathrm{in}$. 
The equation from Timoshenko ${ }^{16}$ used to compute bending stress is

$$
\sigma_{x}=(3 / 4)\left(q a^{2} / h^{2}\right)
$$

where

$$
\begin{aligned}
& q=\text { pressure } \\
& a=\text { radius of the plate } \\
& h=\text { thickness of the plate; }
\end{aligned}
$$

therefore,

$$
\sigma_{x}=(3 / 4)\left[(25)(18.75)^{2} / 0.5^{2}\right]=26,400
$$

Because the stresses are less than the yield stress and the calculated critical buckliig pressires are high, no damage from the external pressure is anticipated. Similar seal configurations have been used considerably in excess of $25 \mathrm{psig}$. It is therefire concluded that the cask complies with the requirements for external pressure.

\subsection{Compliance with Standards for Normal Conditions of Transport}

The regulations for normal conditions of transport for a single package require that the effectiveness of the package wili not be substantially reduced by the normal conditions of transport and that there will be no releage of radioactive material from the containment vessel. The contents of the cask are so limited that there will be no gases or vapors in the package that could reduce the effectiveness of the packaging.

There is no circulating coolant other than atmospheric air, and no mechanical cooling device is required or provided. The cask 18 so designed that the conterts will not be vented to the atmosphere under normal conditions of transport. The applicable normal conditiong include the effects of heat, cold, pressure, free drop, penetration, and compression. 


\subsubsection{Eeat}

The package wst be able to withstand direct sunlight at an abblent tenpecature of $130^{\circ} \mathrm{F}$ in still alr without reducing the effectiveness of the packaging. A comuter program, HaAmG-3,17 nodified to account for naterial phase changes, was used to compute the steady-state temperature distribution in the basic cask nodel and its contents under the speciffed conditions. The calctiational nodel (Fig. 2.1) and computer input (aterial constants) in Sect. 2 vere used in this computation, and the resulting computed temperatures at locations of concern are given in Tables 2.3 and 2.4.

These temperatures w11 have no adverse effect on the cask, nor w111 the container aterials of construction suffer a significant 1088 of physical properties at these temperatures. The allowable continuous operating temperature limit of the silicone rubber gasket is $500^{\circ} \mathrm{F}, 18$ which is significantly higher than the temperatures calculated for the container eeals. The waximm tenperature calculated for the sirface of the container is below that allowable ${ }^{5}$ for sole-use vehicles.

The calculated pressures (Sect. 2.3.4) are $6.4 \mathrm{psig}$ for the cavity, $4.4 \mathrm{psig}$ for the plug-shielding cavity, and $3.61 \mathrm{psig}$ for the body-shielding cavity. See Sect. 1.4 .3 for the combined effects of these pressures with the reduced atmospheric pressure and Sect. 1.6 foi containment vessel design calculations istablishing allowable vessel pressure.

\subsubsection{Cold}

The shlpping package must be able to withstand an amblent temperature of $-40^{\circ} \mathrm{F}$ in st111 air and shade. When the condition of no internal heat load is assumed and the same methods of analysis used for the heat condition (Sect. 2.3.4) are used for $-40^{\circ} \mathrm{F}\left(420^{\circ} \mathrm{R}\right)$, the final or maximum pressure $\left(p_{2}\right)$ in any container cavity sealed at a temperature of $70^{\circ} \mathrm{F}$ $\left(530^{\circ} \mathrm{R}\right)$ and a pressure of 14.7 psia w111 be

$$
P_{2}=P_{1} T_{2} / T_{1}=14.7(420) / 530=11.65 \text { ps1a. }
$$


The resulting pressure differential is not significant when compared with that resulting from the pressure requirements of the regulations for normal transport (Sect. 1.4.3).

A temperature of $-40^{\circ} \mathrm{F}$ is within the operating temperature range of the materials of the cask. Brittle fracture of these materials under the stipuiated cold condition is not credible because the temperature of all the container components will be above their ductile-to-brittle transition cemperatures of the materials of construction. Therefore, the stipulated cold condition will not reduce the effectiveness of the packaging, and it is concluded that the cask complies with the requirements for the cold condition of norwal transport.

\subsubsection{Pressure}

The regulations for normal conditions of transport specify that the package be able to withstand an atmospheric pressure of 0.5 times the standard atmospheric pressure ( $7.35 \mathrm{psia})$. If the effect of reduced pressure is combined with pressure due to cavity tanperature rise (Sect. 2.3.4), the resulting absolute pressures are as shown in Fig. 1.11. The maximum pressure differentials are approximately 12 ps! on each of the outer shell and heads of the cask, top head and outer shell of the plug, and the seal. By comparison with the allowable pressure calculations (Sect. I.6), the specified hydrostatic test pressure of 25 psig for the for the lead cavities and the 20-psig pnetwatic test pressure for the cask cavity (Appendix A, F1g. A.7), it is concluded that these pressures will not reduce the effectiveness of the cask.

\section{4 .4 Vibration}

The regulations require the cask to withstand the vibration experienced In normal transport. Transport vibrations will not, and have not, degraded the cask structurally nor redistributed the shielding. All threaded connections and fasteners are equipped with locking devices such as lockwashers or seal wires; therefore, they will not loosen due to vibration. Properly installed threaded plpe fi:tings do not loosen under transport conditions; thus the cask will withstand transport vil rations. 

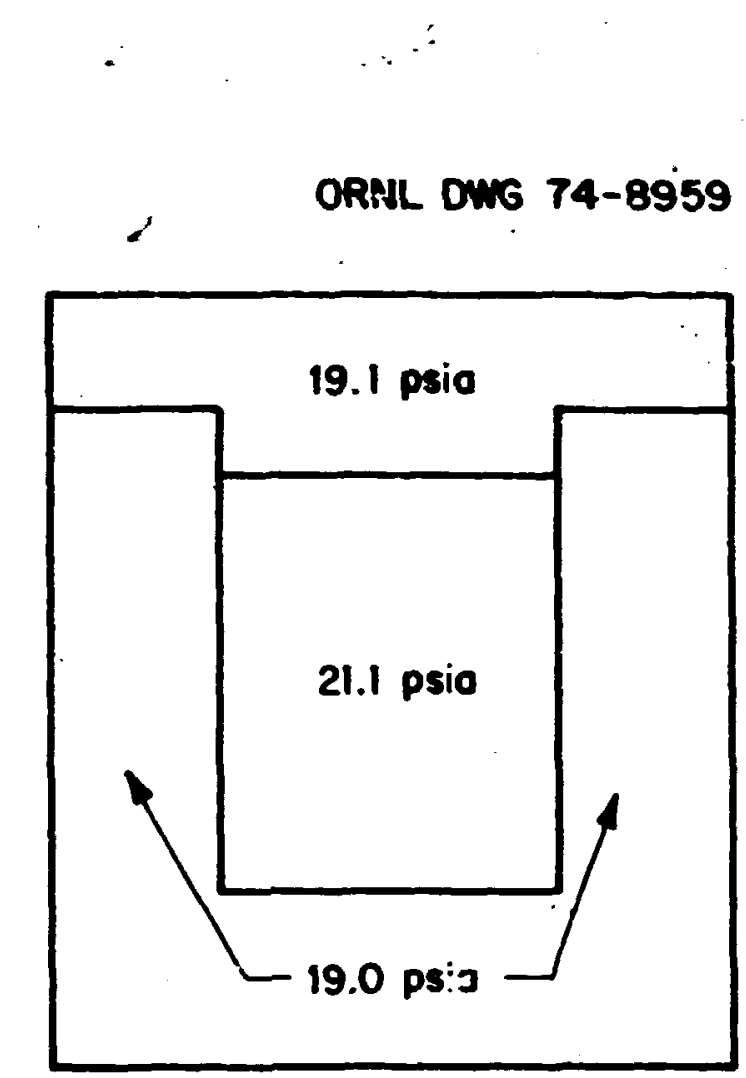

7.35 psia

i

Hig. 1.11: Absolute pressure diagram. 


\subsubsection{Water spray}

It is required that the cask withstand a water spray sufficiently heavy to keep the entfre exposed surface, except the botton, continuously wet for a period of $30 \mathrm{~min}$. The exposed surfaces of the HFIR cask are of type 347 and $304 \mathrm{~L}$ stäinless steel and will be unaffected by water spray.

\subsubsection{Free drop}

The regulations for normal conditions of transport require thas a package veighing between 20,000 and 30,000 lb be capable of withstanding a free drop through a distance of $2 \mathrm{ft}$ onto a flat, essentially unylelding, horizontal surface, striking the surface in a position in which maximum damage is expected to result. The energy to be dissfpated is the cask's potential energy, $U_{p}=W h=23,000(24)=552,000 \mathrm{lb} \cdot$ in. The cask would impact on the external heat transfer surfaces ( $f$ ins or pipes) for all impact orientations. It cannot be determined by inspection which orientation would result in maximum damage. Therefore, impact orientations of (1) top corner, (2) top with the axis of the cask vertical, (3) side, and (4) varfous other orientations will be considered. Demonstration of compliance with this requirement by analytical methods is difficult because experimentally veriffed analytical techniques do not exist, and all the necessary material properties data are not avallable. Drop tests have not been performed on the cask configuration under consideration. The following analyses are presented to conservatively characterize cask response and so demonstrate compliance with the regulations. It is concluded that the ask is adequate to sustain the hypothetical conditions.

\subsubsection{Corner 1mpact. if the cask were dropped on 1 ts curner from} $2 \mathrm{ft}$ so that the point of impact and the center of gravity of the cask vere in a common vertical plane, the radial orientation of the cask resulting in maximum damage would be as determined in Sect. 1.5.1.3. If the pipe extensions contacted the impact surface, they would plastically (permanent1y) deform and absorb the energy. Model tests 'iect. 1.5.1.3) Indicated that a drop from $10 \mathrm{ft}$ would result in a deformation of $7.7 \mathrm{in}$. 
If it is assuned that the energy 13 absorbed during deformation at a constant rate, the expression for the deformation for a $2 \mathrm{ft}$ drop is

$$
\Delta_{2}=\Delta_{10}(2 / 10)=7.7(0.2)=1.54 \mathrm{in} .
$$

where

$$
\begin{aligned}
\Delta_{2} & =\text { deformation at a 2-ft drop, } \\
\Delta_{10} & =\text { deformation at a 10-ft drop. }
\end{aligned}
$$

In actuality, this approach is conservative because structural memers generally absorb a greater quantity of energy during the first portion of collapse or buckling-type fallure. Davis ${ }^{19}$ published data on fins which support this. A deformation of this magnitude would not result in plastic (permanent) deformation in any other cask components. The damage to the pipes would not compromise the cask's containment or shielding capabilities. The reduction in heat transfer capabilities resulting frod local buckling of the four pipes would not be significant. Routine inspection (Sect. 6) would detect the damage, and repairs would be effected prior to additional use.

The corner drop aight also occur at such an orienta:ion so that the carbon steel top-impact absorber first contacts the impact surface. This absorber is designed with the express purpose of absorbing all the energy from a 30-ft drop, and a 2-ft drop will only bend the outer ring." No lamage to cask or loss of shielding will result.

\subsubsection{Impact on the top. It the cask impacts on its top, the} extended pipes will contact the impact surface first and deform (P1g. 0.1). Fron test data (Sect. 1.5.1.1) It is estinated from $\mathrm{F} 18$. 1.23 that the deformation will be $0.4 \mathrm{in}$. The acceleration would not result in stresses in the closure system in excess of the yleld strength as indicated by comparison with Sect. 1.5.1. The eight extended pipes would fall by buckling and would require replacement. The damage would be detected by routine inspection, and repair would be effected. 
1.4.6.3 Inpact on the cask's side. If the cask impacted on its side, the heat transfer surfaces would deform and absorb the kinetic energy. Two radial orientations wil be considered. The first orientation will be where the cask's vertical cente:-line is equidistant between two of the pipes. The second is where the verifal centerline coincides with the center of one of the pipes (F18. 1.27). A comuter progran (Sect. 1.5.1) was used to evaluate response of the cask and deternine the resulting damage. Figures $1.12,1.13,1.14$, and 1.15 are achine plots of the energy vs deforation and the acceieration vs defornation. For the first orientation the resulting deforeation is $0.88 \mathrm{in}$. and the maximum acceleration is $37.2 \mathrm{~g}$ 's. In the second orientation the deformation of the pipe is $1.55 \mathrm{ln}$, and the axdin acceleration is $18.6 \mathrm{~g}^{\prime} \mathrm{s}$. These deflections would not significantly affect the cask's heat transfer capabilities. Structural integrity and contaiment capabilities would not be reduced by an acceleration of this magnitude. The shielding would nor. be radistributed, nor would its effectiveness be reduced. The geometry of the contents and cask internals would not be altered.

1.4.6.4 0ther orientations. A drop on the bottom would locally damage the bottom support structure and cause locallzed buckling of the vertical heat transfer surfaces in the reduced section at this base. A drop on a bottom corner would also result in similar damage. An oblique drop would result in less danage than the corner drop considered in Sect. 1.4.6.1. All these would, as before, cause damage that vould require renaty, but the damage would be detected by pre-usage inspections.

\subsubsection{Penetration}

The regulations for normal conditions of transport stipulate that the package be capable of withstanding the impact of the flat end of a vertical steel cylinder which weighs $13 \mathrm{lb}$, has a diam of $1-1 / 4 \mathrm{in}$. , and is dropped from a height of $4 \mathrm{ft}$, normally onto the exposed surface of the package that is expected to be the most vulnerable to punctura. This conditon will not reduce the effectiveness of the HFIR cask and will result in no more 
$=\cdots \quad 38$

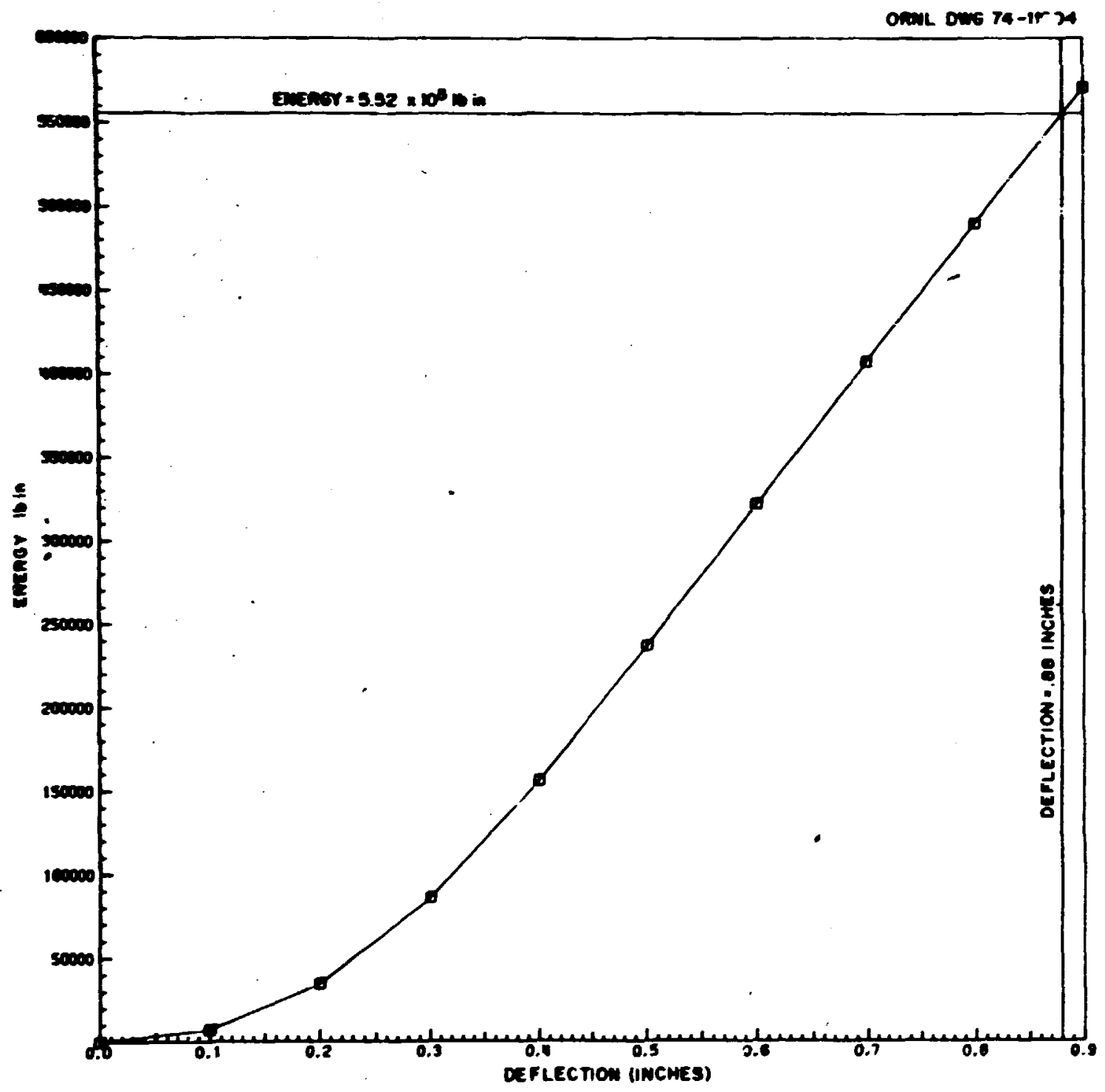

F18. 1.12. Two-ft drop impact on side - case I. 


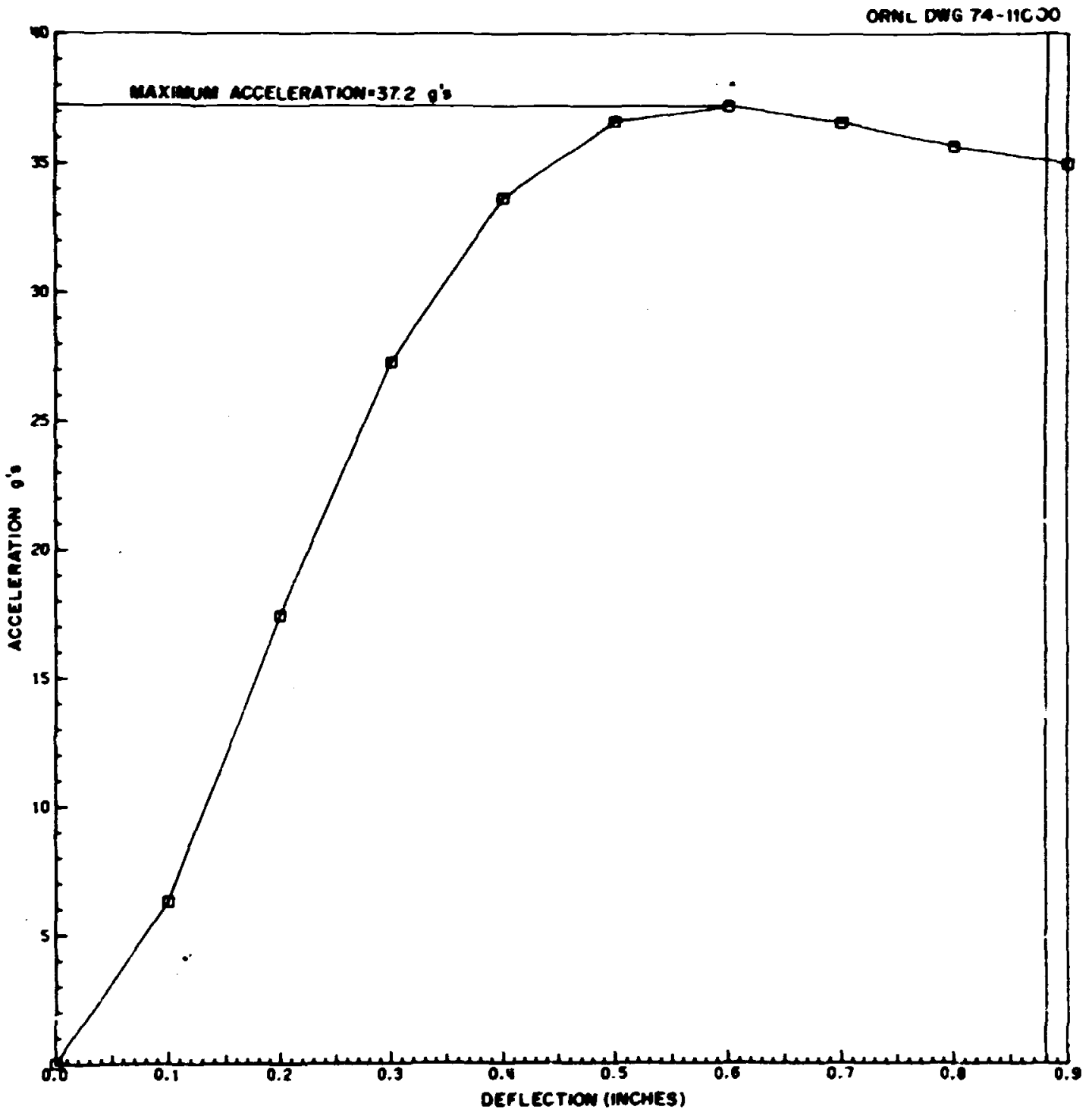

F1g. 1.13. Two-ft drop impact on side - case I. 


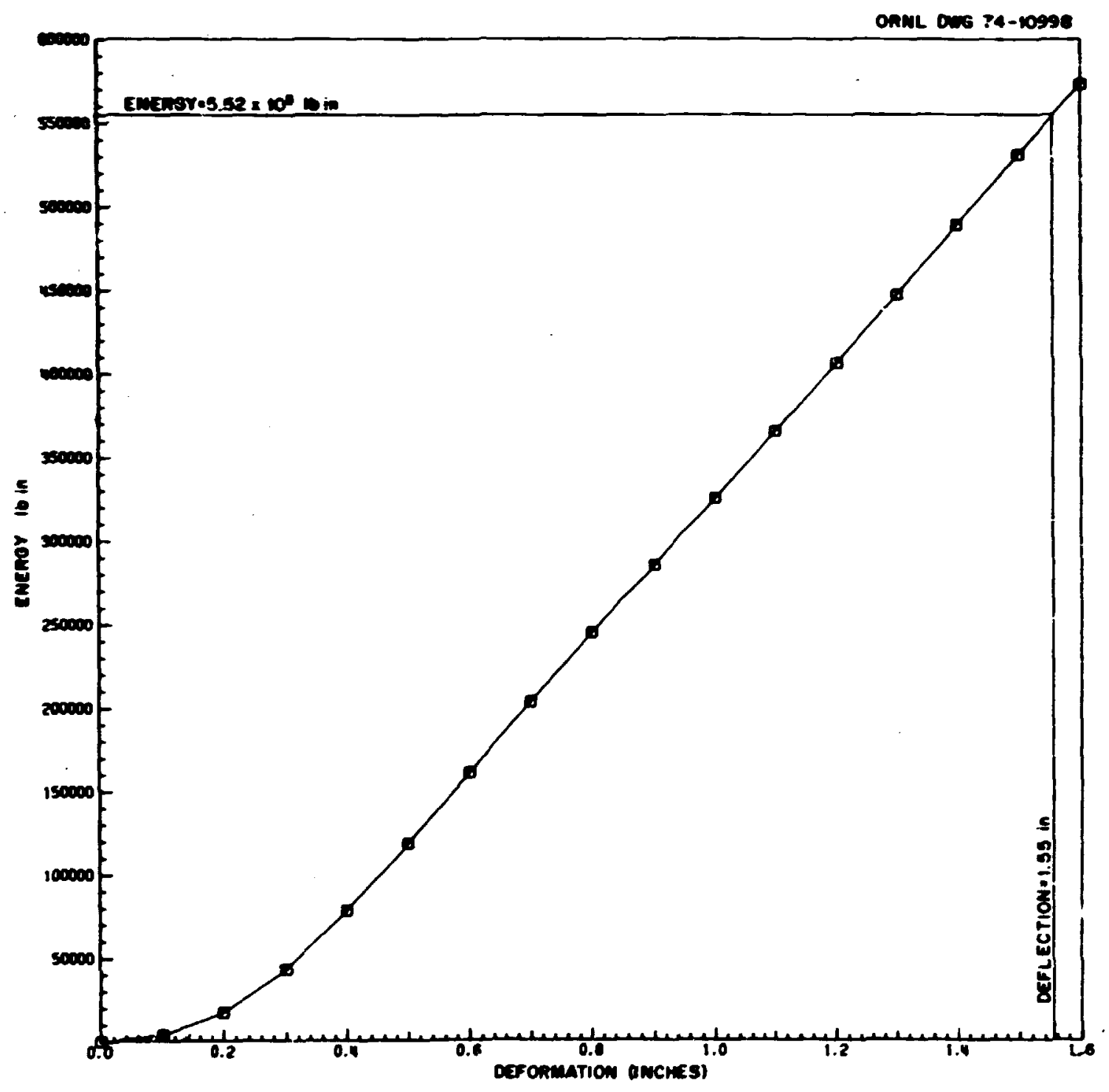

Fig. 1.14. Two-ft drop impact on side - case II. 


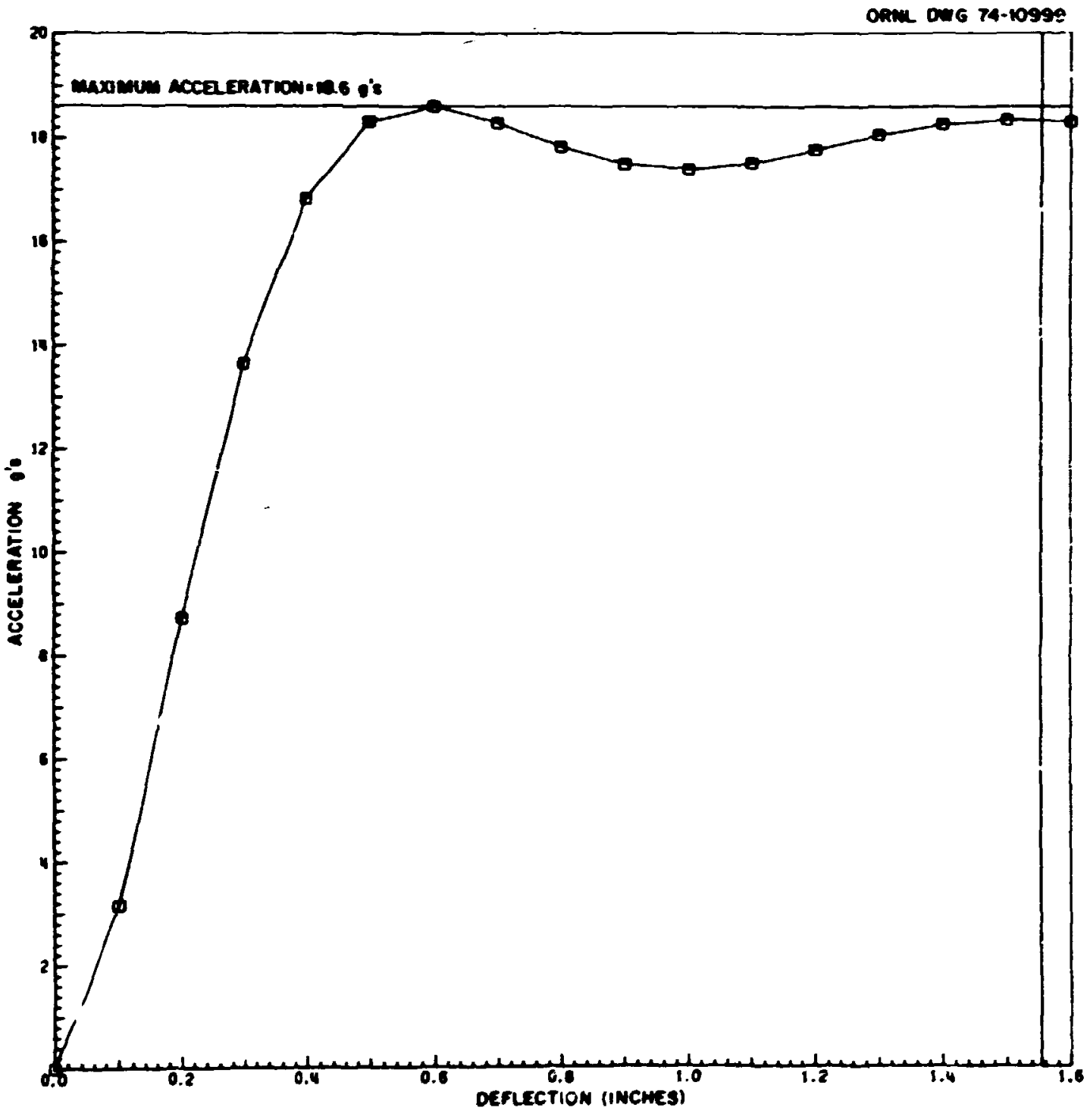

Pig. 1.15. Two-ft drop impact on side - case II. 
than a possible superficial dent in the stainless steel surface of the container.

\subsection{Compliance with Standards for Hypothetical Accident Conditions}

The standards for the hypothetical accident conditions stipulate that a cask used for the shipment of a large quantity of fissile or radioactive aterial shall be so designed and constructed and fits contents so linited that if it is subjected to the specified free dop, puncture, thermal, and water imersion conditions, the reduction in shielding would not be sufficient to increase the external radiation dose rate to wore than 1000 millirems/hr at a distance of $3 \mathrm{ft}$ from the outside surface of the package, no radioactive material would be released from the package except for gases containing zotal radioactivity not to exceed 0.17 of the total radioactivity of the contents of the package, and the contents would remain subcritical.

The first in the sequence of hypothetical accident conditions to which the package must be subjected is a free drop through a distance of $30 \mathrm{ft}$ onto a flat, essentially unylelding horizontal surface, striking the surface in a position in which the maximum damage is expected to occur.

The second in the sequence of hypothetical accident conditions to which the package must be subjected is a free drop through a distance of 40 in. to strike, in a position in which maximi:m damage is expected, the top end of a vertical cylindrical mild steel bar. The bar shall have a diameter of 6 in. with the top horizontal and its edge rounded to a radius of not wore than $1 / 4 \mathrm{ln}$., and the bar shall be of such length that It will cause maximum damage to the cask, but shall not be less than 8 in. long. The long axis of this bar shall be normal to the surface of the package upon impart.

The third in the sequence of hypothetical accident conditions to which the parkage must be subjected is exposure for 30 min within a cource of radiant heat having a temperature of $1475^{\circ} \mathrm{F}$ and an emissivity coefficlent of 0.9 or equivalent. For calculation purposes, it shall be assumed that the package has an absorption coefficient of 0.8 . The package shall not be cooled artifically unt $t$ after the 30 -mir. test pertod has explred and the temperature at the center of the package has 
begun to fall. The effect of the thermal part of the accident is disclissed in Sect. 2.4.

The fourth and last condition in the sequence of hypothetical accident conditions to which the package must be subjected is immersion in water to the extent that all portions of the package are under at least $3 \mathrm{ft}$ of water for a period of not less than $8 \mathrm{hr}$. The cask remains sealed after the impact and thermal exposure and is constructed of stainless steel; hence it would suffer no ill effects from the vater immersion.

\subsubsection{Thirty-ft free fall}

Demonstration of compliance with this requirement by analytical methods is difficult because experimentally verified analytical techniques do not exist, and all the necessary aterial properties data are not available. Drop tests have not been performed on the cask configuration under consideration. The following analyses are presented to conservatively characterize cask response and so to demonstrate compliance with the regulations. It is concluded that the cask is adequate to withstand the hypothetical conditions.

It cannot be determined by inspection which orientation would result in maximum damage if the cask were dropped from $30 \mathrm{ft}$ onto an unyielding surface. The cask's length-to-diameter ratio of 1.4 to 1 does indicate that out-of-plane bending is not a realistic consideration. Therefore, an oblique drop (that is, one in which the axis passing througi the center of gravity of the cask and the point of impact is not normal tn the impact surface) is not as significant as a full side impact or a corner impact. It is also obvious that a drop onto a bottom corner is less damaging than a drop onto a top corner due to the proximity of the closure to the top corner. Therefore the effects of a drop onto the top and bottom with the axis of the cask vertical, a drop onto the side with the axis of the cask horizontal, and a drop onto the top corner with the plane passing through the center of gravity of the cask and the point of impact vertical, w11 be determined. 
1.5.1.1 Drop onto the top. When the cask inpacts on 1 ts top (with the axis vertical), the eight extended 4-in. sched.-80 pipes will contact the surface first; these pipes will fall and absorb energy, and the cask body will also plastically deform and absorb energy. The majority of the cask's kinetic energy will be dissipated in these two modes. For the calculaticn, it will be assumed that all the energy is absorbed in this manner. We will assume that the entire cask accelerates as a unit, that 1.8, that all parts of the cask have the same acceleration with respect to time. The approach of solving two separate problens, one in which energy is absorbed only in the pipes and one in which energy is absorbed in the cask body, and superimposing the results, will be used.

The ORNL computer program CEIR ${ }^{20}$ is used to evaluate the energy absorbed and deforations in the cask body. CEIR is written to calculate the response of a cylindrical, metal-clad, lead-shielded cask to an impact. with an unylelding surface. The top head of the cask is assumed to be rigid, and the effect of the internal heat transfer connectors (fins) on the movement of lead w111 be neglected. The strengthening effect of these connectors on the shell in the circumferential direction was conservatively estimated by using an effective shell thickness bas ad on the cross-sectional area of the fins. This relationship 18

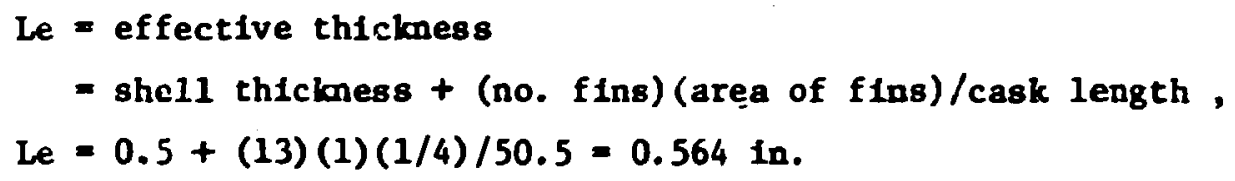

This thickness is used in the computer calculation for end impact. The response of the pipes could not be calculated based on theory, and no applicable experimental tata cuuld be found. Three 2.35-to-1 scale models were tested as described in the test procedures and reports in Appendix E. The test model is 11lustrated in Figs. 1.16 and 2.17. The damage to the models 18 shown in Fig. 1.18. Force data with respect to time were caken for each Impact and converted to force-deflection relationships as described in reía. 19, 21, and 22 . Scaling laws were used to convert the model data to data applicable to the full-sized absorbers. These laws are $F=F_{m}(S F)^{2}$ and $\Delta=\Delta_{m}(S F)$, where 


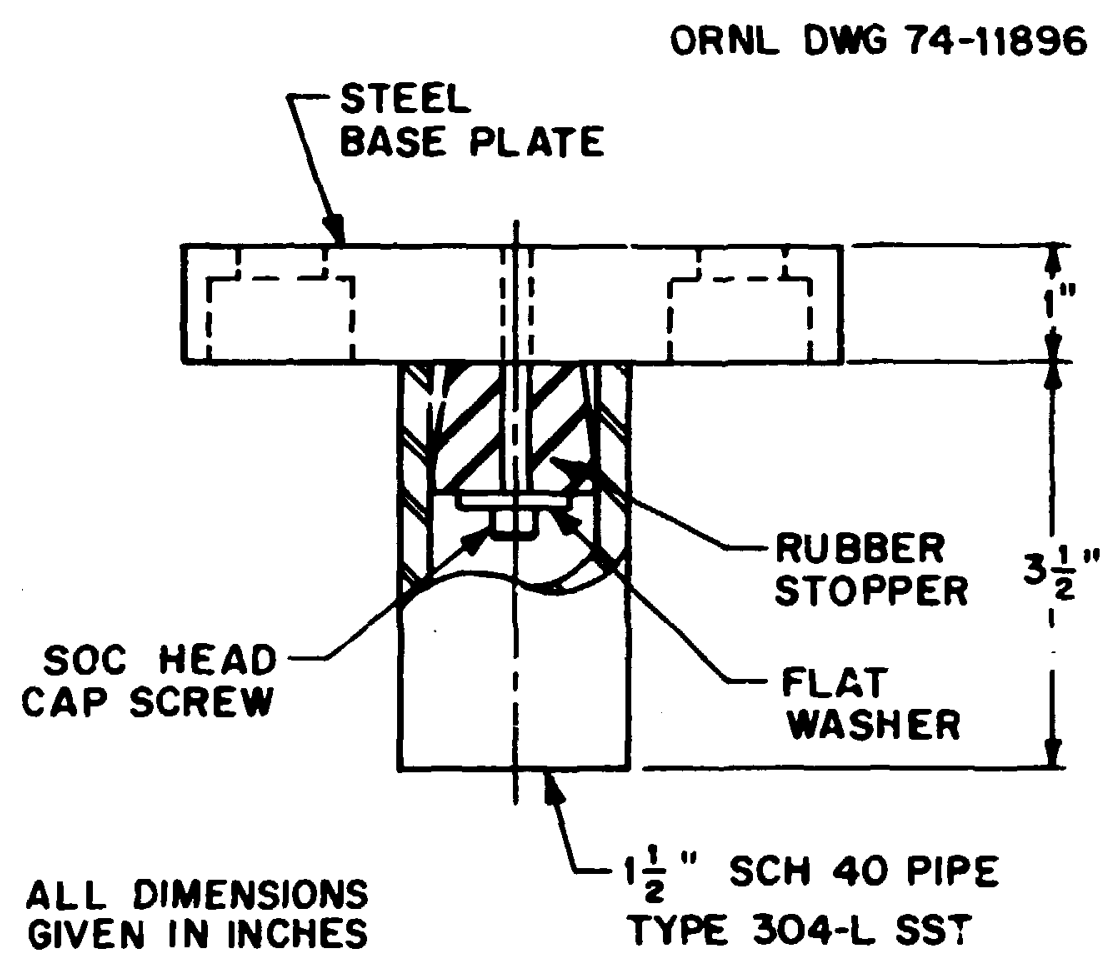

F1g. 1.16. 2.35-to-1 test model (drawing). 


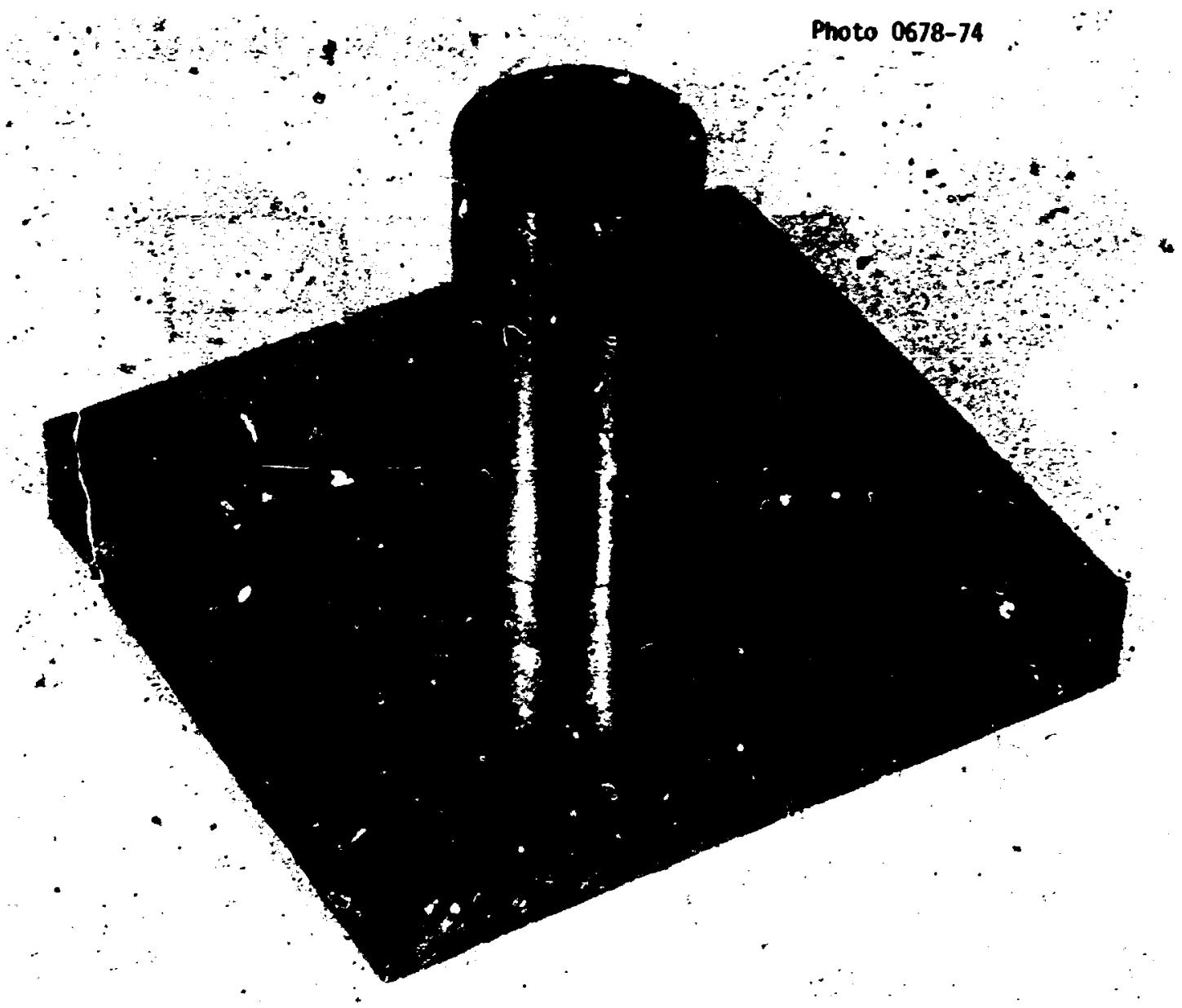

F1g. 1.17. 2.35-to-1 test model (photograph). 


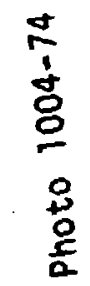
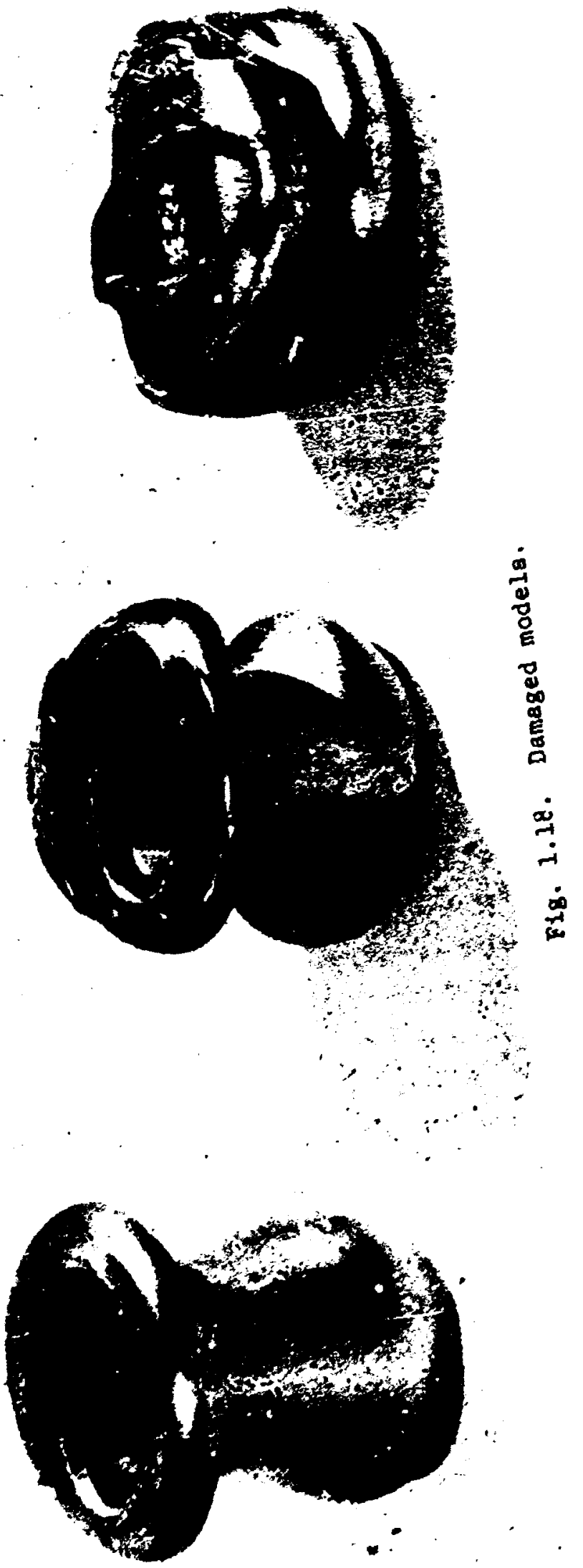
$F=$ force applied to the full-sized absorber (1b).

$F_{\text {. }}$ - force applied to the model (1b) ,

SP = scale factor or ratio of dimensions $=\frac{\text { actual dinensions }}{\text { odel dimensions }}$,

$\Delta=$ deflection of the full-sized absorber (1n.) ,

$\Delta_{\mathrm{a}}=$ deflection of the nodel (1n.)

A machine plot of the force-deflection curves applicable to full-sized abso-bers 18 shown in P18. 1.19. An 1ith-order polynomial equation representing these data was written, and a plot of the ecration is also shown In F18. 1.19.

An existing ORN computer progran, 1010 CASR, which employs sumation techniques and a force and deflection equation to conpute absorbed energy, was used to calculate the response of the absorbers. The derivation of equations and a program 11sting are in Appendix $F$. The eleven constants shown in the listing are the constants as clated with the polynomial equation.

Hachine plocs of absorbed energy vs acceleration for the cask body, calculated using CEIR, and for the pipes, calculated using 1010 CASR, are shown in Pigs. 1.20 and 1.21. The plot for the pipe absorbers was Idealized as shown to simplify the solution described below. It was deternined by trial and error that all the casi's energy of $8.28 \times 10^{6} \mathrm{in} . \cdot 1 \mathrm{~b}$ would be absorbed by deforming the pipes and the cask body when the cask's acceleration reached about $125 \mathrm{~g}^{\prime} \mathrm{s}$ (P1g8. 1.20 and 1.21).

Frow F1g. 1.22, a machine plot of the deforwation of the shielding vo the acceleration as couplled by CEIR, it can be seen that shielding would deform $1.24 \mathrm{in}$. The actual deformation would be somewhat less than this since the effects of lead bonding and the internal fins were neglected. Froa Fig. 1.23, a machine plot of absorbed energy vs deflection for the eight plpes as computed by 1010 CAST, it can be seen that the deflection of the pipes would be about $1.57 \mathrm{in}$. It is recognized that the deformation would be somewhat greater than calculated due to assumptions made about the body. This 18 of no concern since the pipes have the capacity to absorb all the cask's energy of $8.28 \times 10^{6} \mathrm{in.} \cdot 1 \mathrm{~b}$ while deforming $3.08 \mathrm{in}$. 


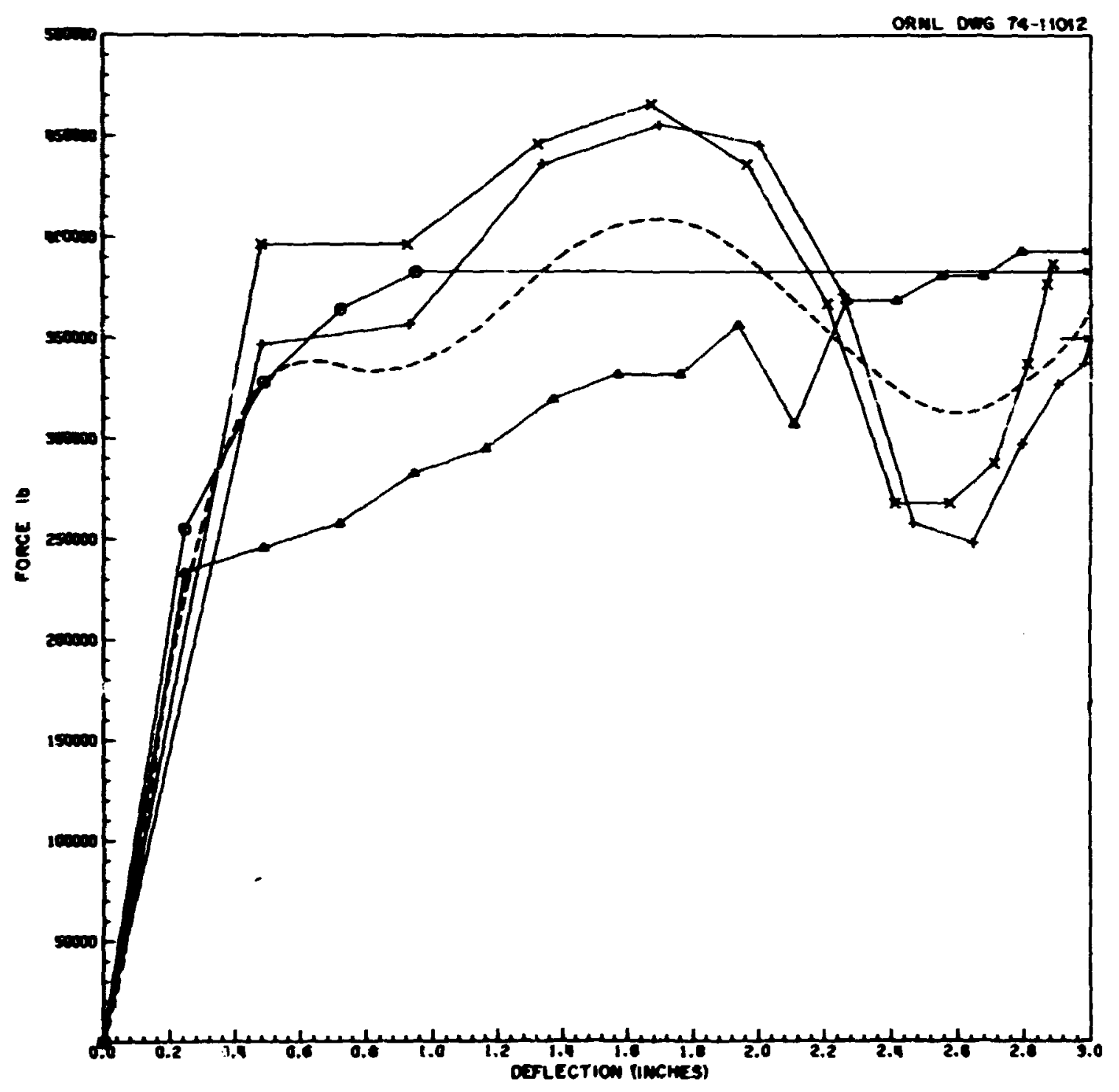

Fig. 1.19. Model data. 


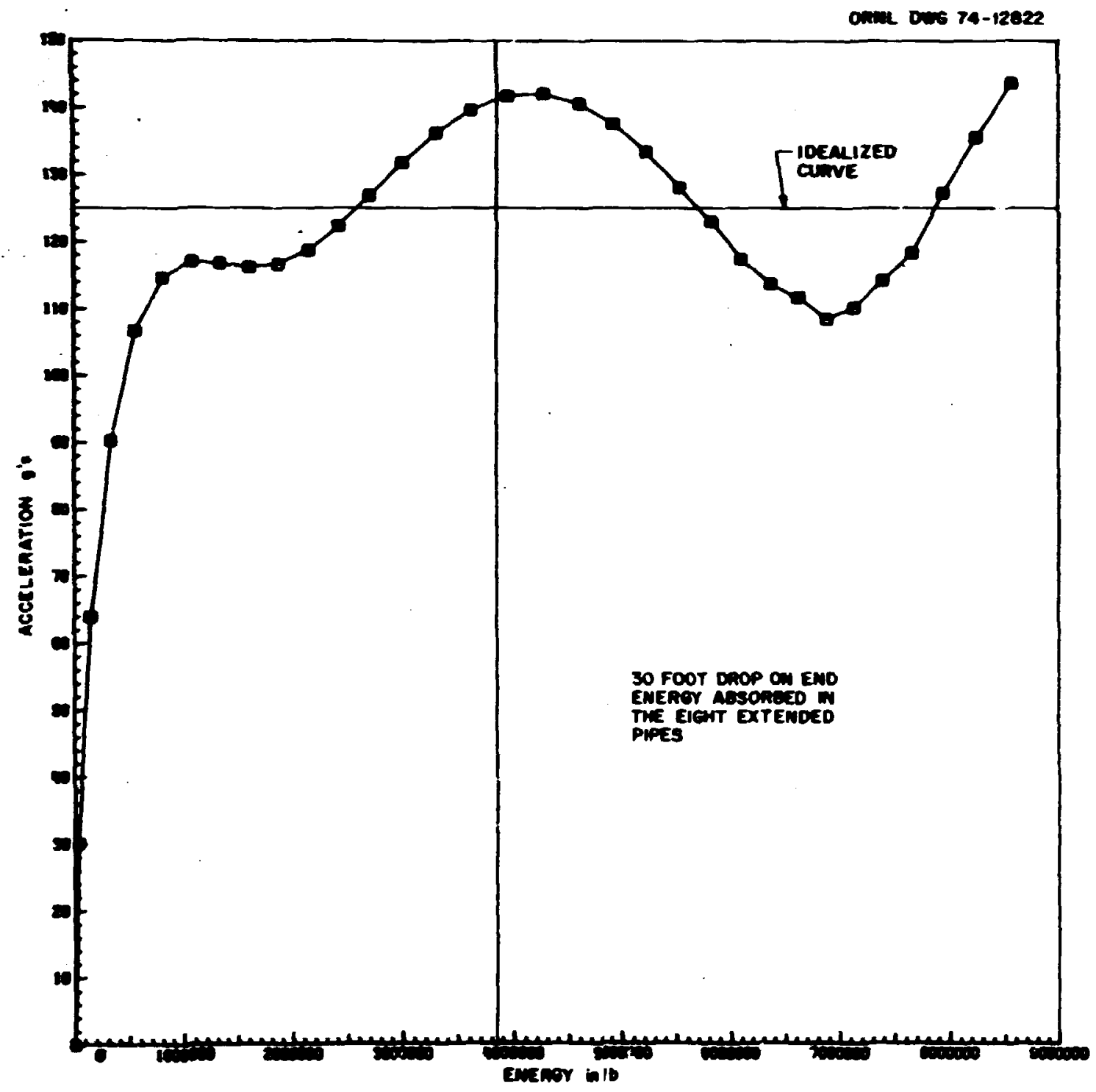

F1g. 1.20. End 1mpact, energy absorbed in eight extended pipes. 
51

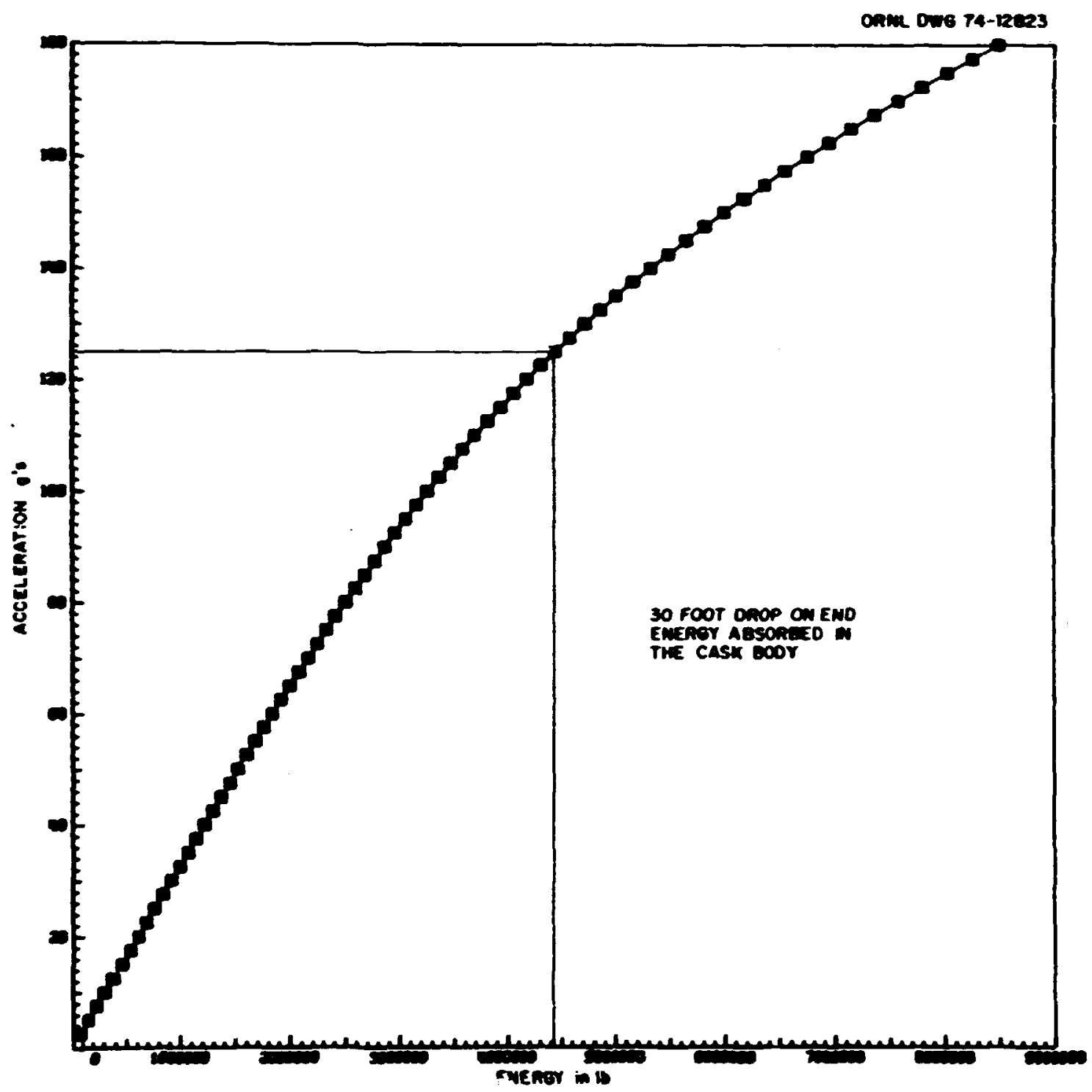

Fig. 1.21. End Impact, energy absorbed in the cask body. 


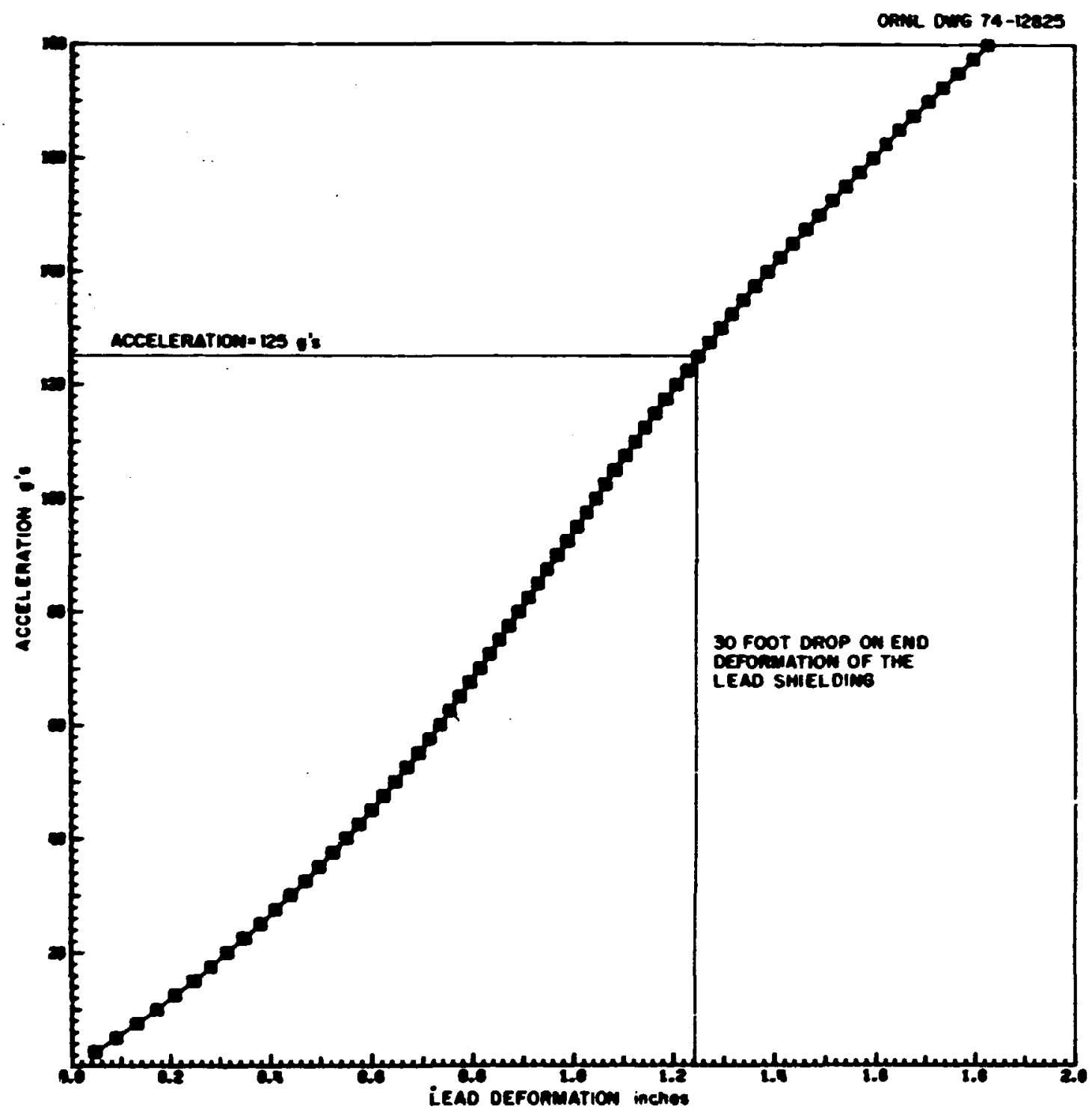

Fig 1.22. End impact - deformation of lead shielding. , 


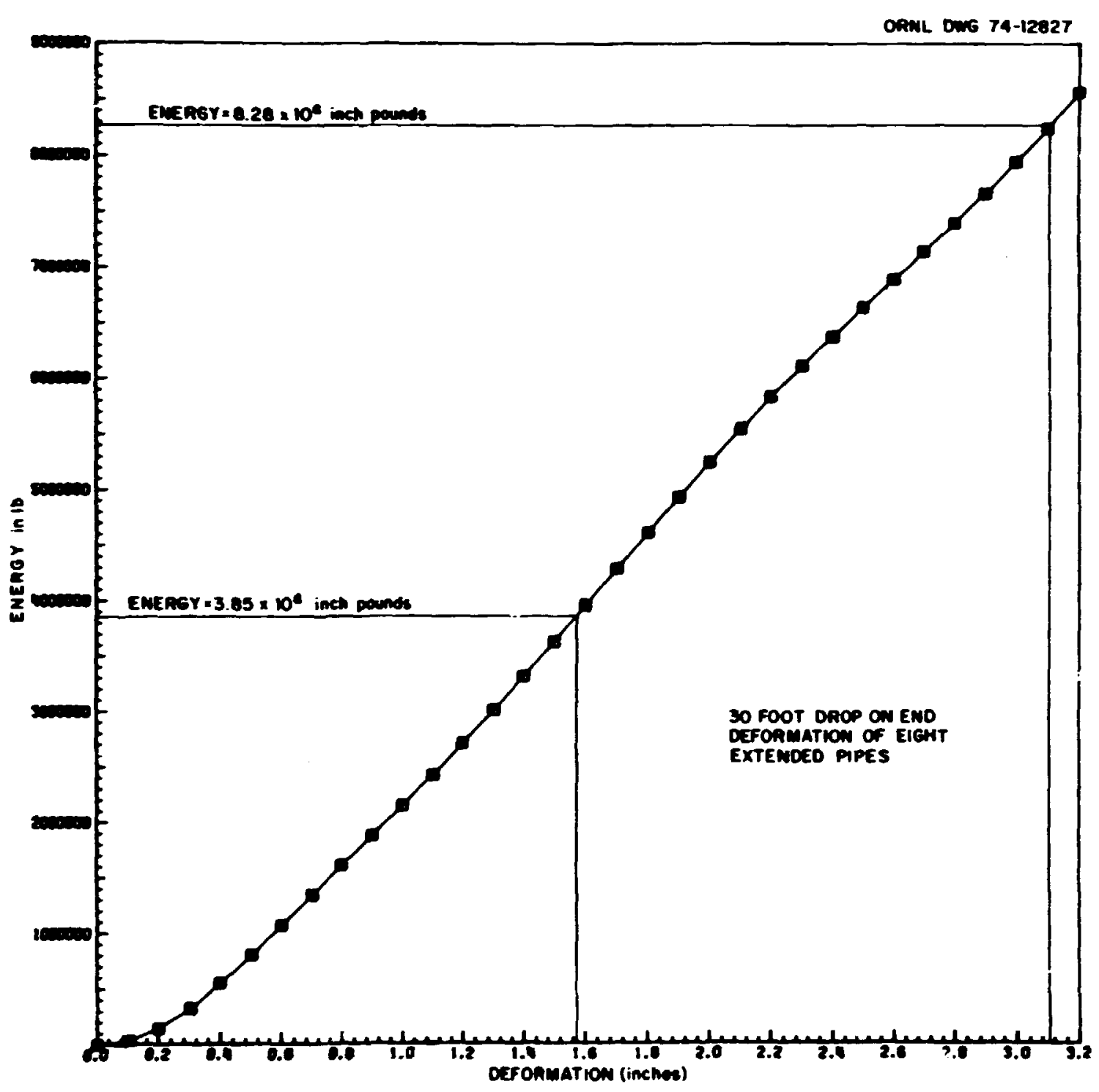

Fig. 1.23. End 1mpact - deformation of eight extended pipes. 
With an acceleration of $125 \mathrm{~g}^{\prime} \mathrm{s}$, the cask plug, which weighs $2100 \mathrm{lb}$, would exert a force

$$
F=W_{a} / g=2100 / 8(1258)=262,5001 b \text {, }
$$

on the fasteners securing the plug. The stress in the fourteen $1-1 / 2-$ in. studs is therefore

$$
\sigma=F / \mathrm{NA}=262,500 /(14)(1.4)=13,400 \mathrm{psi} \text {. }
$$

where

$$
\begin{aligned}
& N=\text { number of studs } \\
& A=\text { stress area } \\
& 13 \text { of one stud }
\end{aligned}
$$

Since the calculated stress is below yield stress (Fig. 1.3), the studs will not fail.

-

1.5.1.2 Drop onto the side. If the cask were dropped onto the side, the vertical heat transfer pipes would contact the surface first. Some enersy would be dissipated in flattening these pipes. The remaining energy would be dissipated by deforming the body (shielding, end plates, and shel1). There are two radial cask orientations of interest (Fig. 1.24). It cannot be determined by inspertion which orientation will result in maximum cask damage; hence, the response of the cask will be determined for both orientations. The general approach, superpusition of results, will be utilized; that is, the energy, forces, and/or accelerations associated with collapse of the pipes will be determined and added to the corresponding values for deforming the cask body. The information, test results, and techniques to be used to effect these separate solutions are discussed in the material below.

In 1971, whlle teating the tube in the pipe energy absorber, a number of 4-in.-long sections of 1-1/4-, 1-1/2-, and 2-1/2-in. sched.-40 stainless steel pipes were impacted in a manner described in Structural Analysis of Shipping Casks. ${ }^{21}$ Testing indicated that the pipe sections 

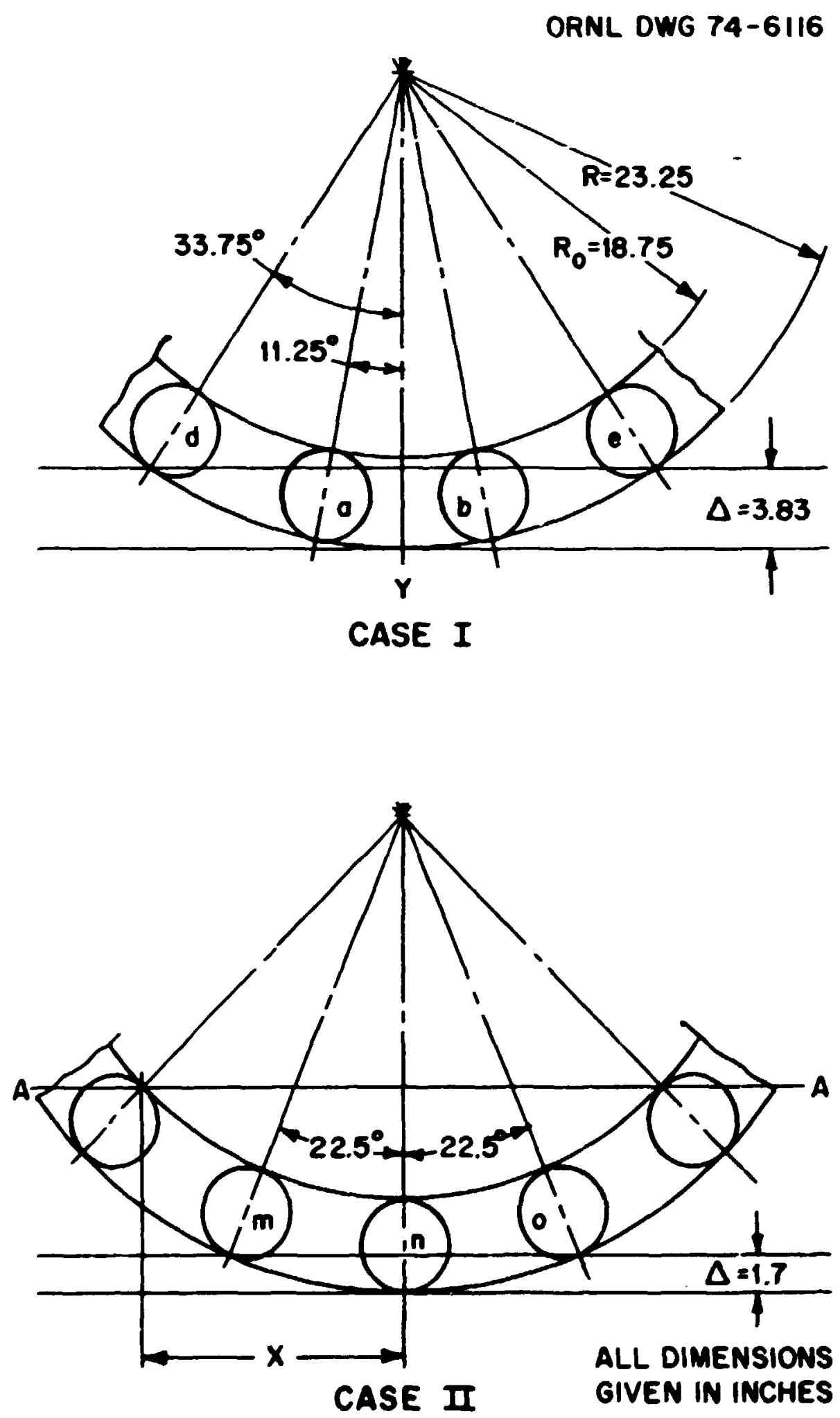

Fig. 1.24. Side-drop orientations. 
would not absorb a quantity of energy sufficient to make them applicable as energy absorbers for large casks; hence, the data vere filed but not included in the report. ${ }^{21}$ The test parameters are given In Table 1.2.

Table 1.2. Test Parameters

\begin{tabular}{cccccc}
\hline $\begin{array}{c}\text { Test } \\
\text { no. }\end{array}$ & $\begin{array}{c}\text { OD } \\
\text { (in.) }\end{array}$ & $\begin{array}{c}\text { Wall } \\
\text { thickness } \\
\text { (in.) }\end{array}$ & $\begin{array}{c}\text { Weight } \\
\text { dropped } \\
\text { (1b) }\end{array}$ & $\begin{array}{c}\text { Drop } \\
\text { distance } \\
\text { (in.) }\end{array}$ & $\begin{array}{c}\text { Length } \\
\text { (1n.) }\end{array}$ \\
\hline 1 & 1.660 & 0.140 & 99.0 & 160.3 & 4.0 \\
2 & 1.660 & 0.140 & 99.0 & 132.3 & 4.0 \\
3 & 1.660 & 0.140 & 25.0 & 360.0 & 4.0 \\
4 & 2.875 & 0.203 & 99.0 & 216.0 & 4.0 \\
5 & 2.875 & 0.203 & 99.0 & 276.0 & 4.0 \\
6 & 2.875 & 0.203 & 99.0 & 359.3 & 4.0 \\
7 & 2.375 & 0.154 & 99.0 & 205.0 & 4.0 \\
8 & 2.375 & 0.154 & 25.0 & 360.0 & 4.0 \\
9 & 2.875 & 0.203 & 25.0 & 360.0 & 4.0 \\
\hline
\end{tabular}

These data include the test parameters of pipe size, drop height, impacting welght, and a photographic record of the applied force with respect to time. These data were input into an existing computer program CIDR 22 that performs two successive numerical integrations of the force-time data to produce force-deflection data. Scaling theory was applied to the forcedeflection values obtained to wake them applicable to the 4-1n. sched.-80 pipes around the clrcunference and on the bottom of the HrIR cask. The scale factor used 18 an average of the scale factor for the outside diameter and the wall thickness.

Scale factor $=\left(D_{4} / D_{T}+T_{4} / T_{T}\right) / 2.0$,

where

$D_{1}=$ 4-1n. -OD sched. -80 p1pe $=4.5 \mathrm{in}$.,

$D_{T}=O D$ of test endel,

$T_{4}=$ wall thicknese of $4-1 \mathrm{n}$. 8 ched. -80 pipe $=0.337 \mathrm{in}$.,

$T_{T}=$ wall thickness of test wodel . 
A machine plot of force-deflection data converted to be applicable to the HFIR case (4-in. sched.-80 pipe) is shown in Fig. 1.25. A polynomial equation of the data resulted in the efguation

$$
\begin{aligned}
& F=F(X)=A+B X+C X^{2}+D X^{3}+E X^{4}+G X^{5}+H X^{6}+I^{7}+J X^{8} \\
& +\mathrm{KX}^{9}+L X^{10}+\mathrm{CX}^{11}
\end{aligned}
$$

where

$$
\begin{aligned}
& F=\text { applied force (1b/in. of pipe length) } \\
& X=\text { deformation (in.), } \\
& A=93.8673136 \text {, } \\
& B=-1543.76612, \\
& C=167064.376 \text {, } \\
& \mathrm{D}=-572233.512 \text {, } \\
& E=908127.888 \text {, } \\
& G=-833589.816 \text {, } \\
& i_{i}=479988.152 \text {, } \\
& I=-178859.680 \text {, } \\
& J=43092.56 \text {, } \\
& R=-6478.59232 \text {, } \\
& \mathbf{L}=552.37508 \text {, } \\
& M=-20.3866008 \text {. }
\end{aligned}
$$

This equation is best solved by computer. A less accurate equation,

$$
F=1689+2993 X \text {, }
$$

suitable for hand calculation, was alsc written. $F$ and $X$ are as above. The curves produced from the polynomial equation are plotted with the data from which they were written, as in Fig. 1.25. These data will be used to establish the energy dissipated in flattening the plpes for both cases.

A general program, $1010 \mathrm{CASK}$, was modifled with these 11 constants and used to compute the response of a cask equipped with empty pipe absarhers. A listing of the program with another set of data is presented 


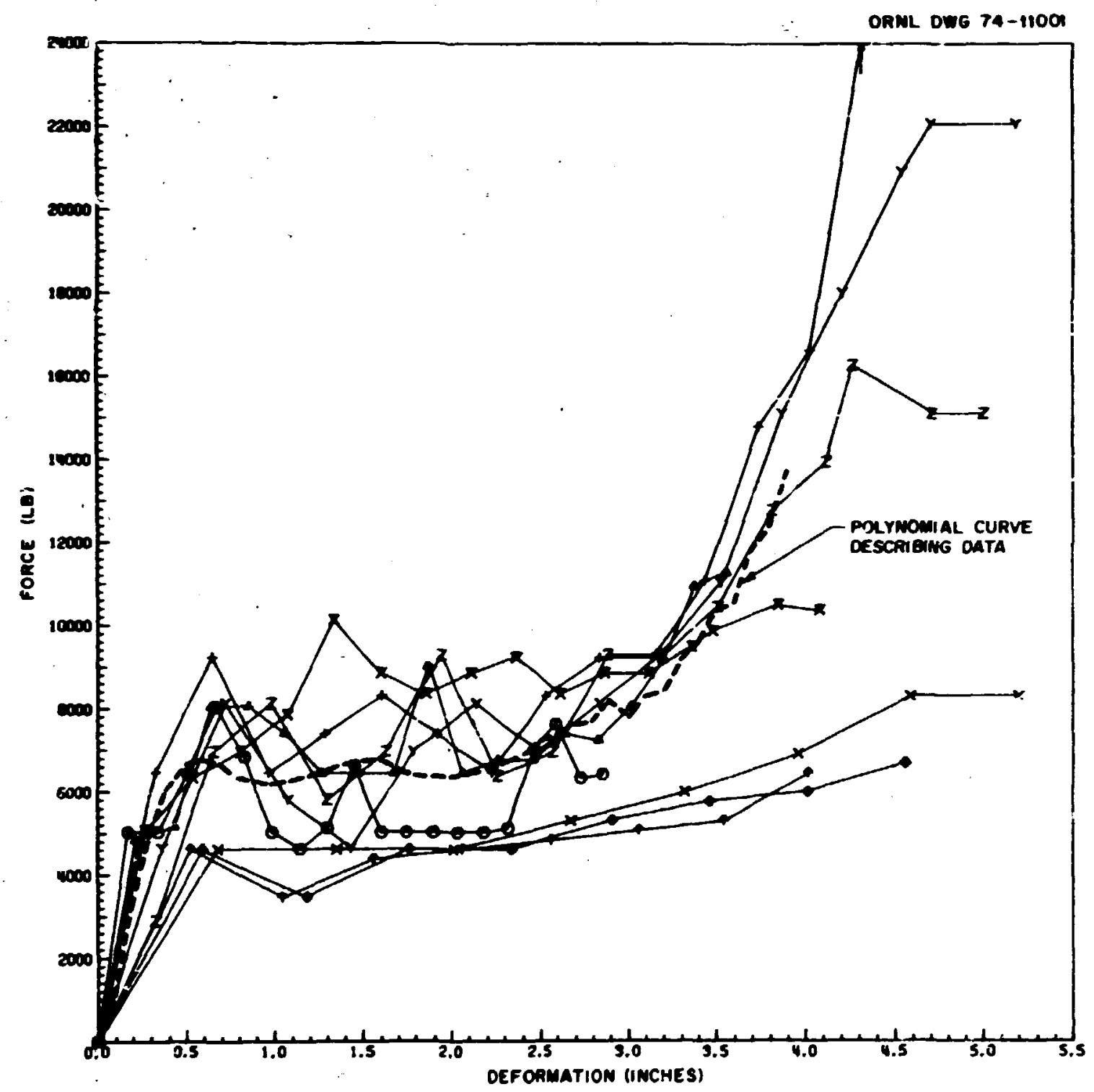

F1g. 1.25. Pipe impact data. 
in Appendix F. This is ths same approach as used in Sect. 1.5.1.1 for the eight extended pipes.

That portion of energy dissipated in deforming the cask body is estimated using an existing ORNL computer program, 1005 CASK (see Appendix $F$ for equation derivations and listing). Both the top and botiom heads of the cask are stiffened with external structural bracing. Since the program is written for unbraced flat heads, the stiffening effect of the bracing is estimated as outlined below.

As the top head is compressed, at least three of the 3/8- by 7-1/2in.-high gussets will also be compressed. Taking a section at A-A in Fig. 1.24, case II, the length $X$ is

$$
X=R_{0}\left(\sin 45^{\circ}\right)=18.75\left(\sin 45^{\circ}\right)=13.26
$$

The area in compression, $A_{T}$ at this place, is

$$
A_{T}=2 X t+(N)\left(t_{g}\right)\left(L_{g}\right)=2(13.26)(1)+(3)(3 / 8)(7.5)=34.96,
$$

where

$$
\begin{aligned}
t & =\text { thickness of the } f\left(l_{i}\right. \text { head (in.) } \\
X & =\text { distance as shown in Fig. } 1.24 \text { (in.) } \\
N & =\text { number of gussets } \\
t_{8} & =\text { gusset thickness (in.) } \\
L_{8} & =\text { length of the gussets (in.). }
\end{aligned}
$$

A plate thickress $t_{h}$ to give an equivalent area is

$$
\begin{aligned}
2 X t_{h} & =A_{t}, \\
\tau_{h} & =A_{t} / 2 X-34.76 i ?(13.26)=1.32 \mathrm{in} .
\end{aligned}
$$

Likewise the 1/2-1n, -thick bottom head is stiffened by one 4-1n. sched, -80 plpe and the 1-in.-thick base plate. The failure mode of the base ring would probably be a complex combination of bending and local compression. Also the base ring will absorb energy well in advance of any 
defornation of the shell and lead. In the interest of calculational simplicity and because it resuiiz in a conservative damage eatinate, the effect of the base ring will be ignored. Hence the equivalent thickness $T_{\text {hh }}$ for the botton head taktng a reference plane as for the top head is

$$
\begin{aligned}
T_{h h} & =2 X t+A p / 2 X=2(13.26)(0.5)+4.407 / 2(13.26) \\
& =0.666 \text { in. }
\end{aligned}
$$

where

$$
A_{p}=\text { area of pipe in compression. }
$$

The progran is based on materials having ideal dynamic stress-strain properties. It can be seen fron Figs. 1.1 and 1.2 that this is not true for lead and stainless ateel. A conservative solution is effected by calculating the response, taking values for dynamic yield stress which. envelop the actual curve, and effecting two solutions. The solution using the lower stress value for both materials will indicate a deformation which is greatar than actual deformation. Likewise, the higher value will predict an acceleration which is higher than actual. The values taken for this calculation are those outlined in Sect. 1.1.

For the orientation identified as case I, Fig. 1.24, two pipes adjacent to the vertical centerifne, Identified as a and $b$, will completely collapse before the shell begins tc deiorm. From F1g. 1.26, a machine plot from the program $1010 \mathrm{CASK}$, it can be determined that $3.45 \times 10^{6} 1 \mathrm{~b} \cdot \mathrm{in}$. of the energy would be absorbed in flattening the two pipes to their solid height. The remaining energy ( $\left.4.83 \times 10^{6} \mathrm{lb} \cdot 1 \mathrm{n}.\right)$ would be dissipated in deforming the shell and deforming pipes e and $d$ (Fig. 1.24). It can be seen that pipes $e$ and $d$ would begin to collapse slightly before the shell contacted. In the interest of simplicity we will neglect this and assume that these pipes and the shell begin to deform simultaneously. By trial and etror it was found that at a deflection of $1.19 \mathrm{in}$., the remaining $4.83 \times 10^{6} 1 \mathrm{~b} \cdot 1 \mathrm{n}$, of energy would be absorbed by the combination of the cask body and pipes and $d$, If we assumed the lower values for dynamic yleld stress. (See P1g. 1.26, the energy-deflection curve for the two 


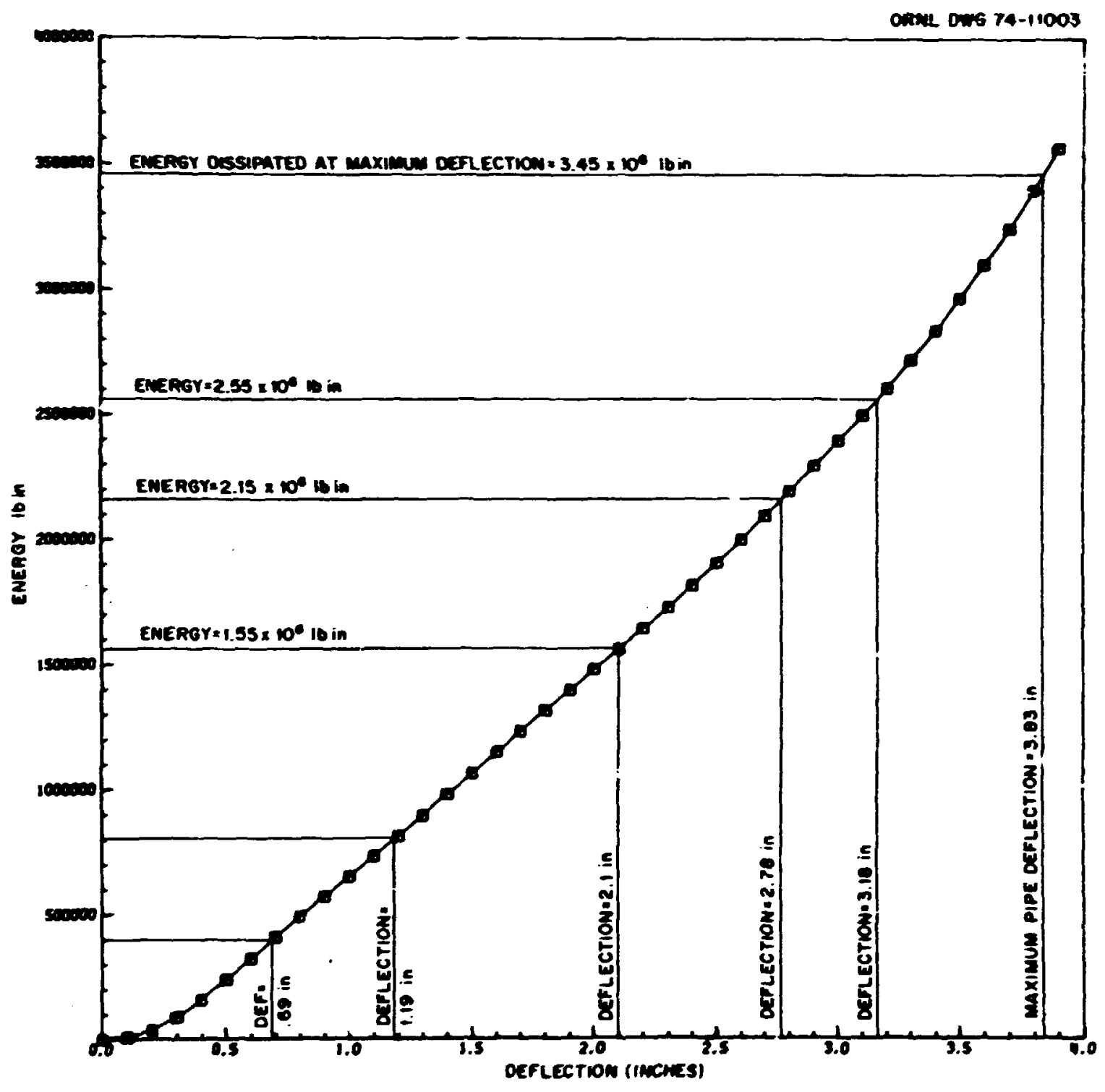

F1g. 1.26. Side-drop responses of two pipes. 
pipes, and Fig. 1.27, an energy-deflection plot of the results computed with 1005 CASK assuning the lower values for dynanic yield stress.) Sinilarly, taking the dynanic yield stress at the upper value, the deflection would be $0.69 \mathrm{in}$. (PIgs. 1.26 and 1.28). The acceleration would be a maximu for the upper value of dynanic yield stress and would be the su of the acceleration attributable to pipes $e$ and $d$ and the body. Fron Figs. 1.29 and 1.30 it can be seen that at a deflection of 0.69 in., the accelerations are

$$
\begin{aligned}
& a_{p}=37 \mathrm{~g}^{\prime} \mathrm{s}, \\
& a_{b}=425 \mathrm{~g}^{\prime} \mathrm{s},
\end{aligned}
$$

where $a_{p}$ is the acceleration component attributable to the pipes and $a_{b}$ is the component attributable to the body. The acceleration of the cask Is $4628^{\prime} \mathrm{s}$.

For case II, the pipe on the vertical centerline, identified in Fig. 1.24 as $\mathrm{n}$, would contact the impact surface first and def ject about 1.7 in. before pipes and o would contact the surface. The energy dissipated during this portion of the impact is found to be $0.6 \times 10^{6}$ 1b.1n. from Fig. 1.31, an energy-deformation plot for one pipe. Pipe $n$ will deflect to solid height and pipes $m$ and $o$ will deflect $2.1 \mathrm{in}$. before the body begins to deform. At this point, the energy dissipated is the sum of that absorbed by pipes $m, n$, and $o$. The numerical value can be found from Fig. 1.31 at the applicable deflection of $3.83 \mathrm{In}$. and FIg. 1.26 at the applicable deflection of $2.1 \mathrm{in}$. The energy absorbed by the three pipes $1 \mathrm{~s} 3.27 \times 10^{6} \mathrm{lb} \cdot \mathrm{in}$. The remaining $5 \times 10^{6} \mathrm{lb} \cdot \mathrm{in}$. will be dissipated in deforming the body and in the continued deflection of pipes $n$ and 0 . As before, the deformation can be found from Figs. 1.26, 1.27, and 1.28. For the lower value of dynamic yield stress applicable to the materials in the cask bod;, the body deflection 18 slightly less than for case I at $1.18 \mathrm{in}$. Similarly, for the upper value of dynamic yield stress, the deflection 18 found to be $0.68 \mathrm{in}$. The resulting acceleration would be slightly less than for case $I$. 


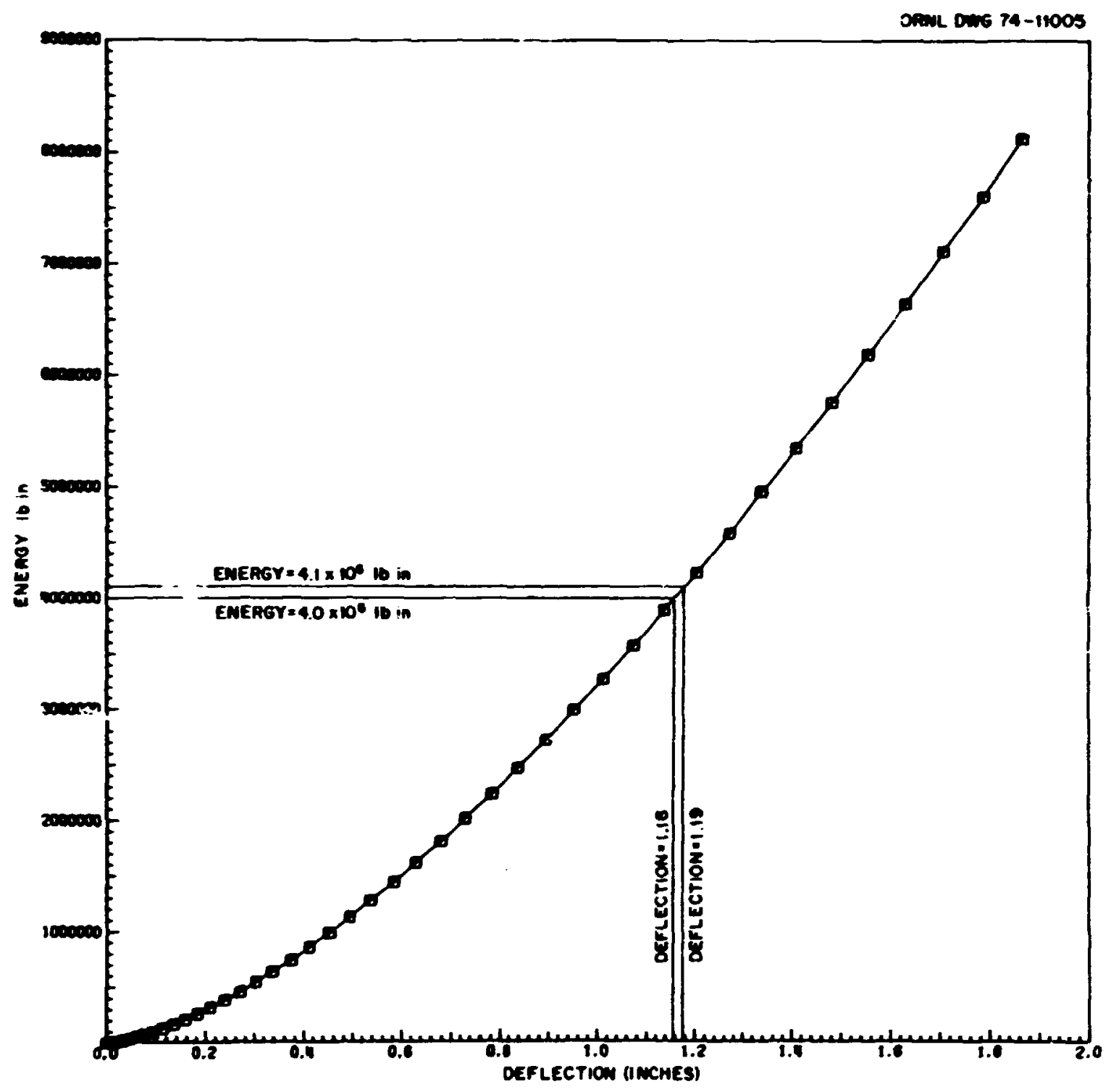

F1g. 1.27. Side-drop dynamic yield stress $=6000 \mathrm{psi}$. 


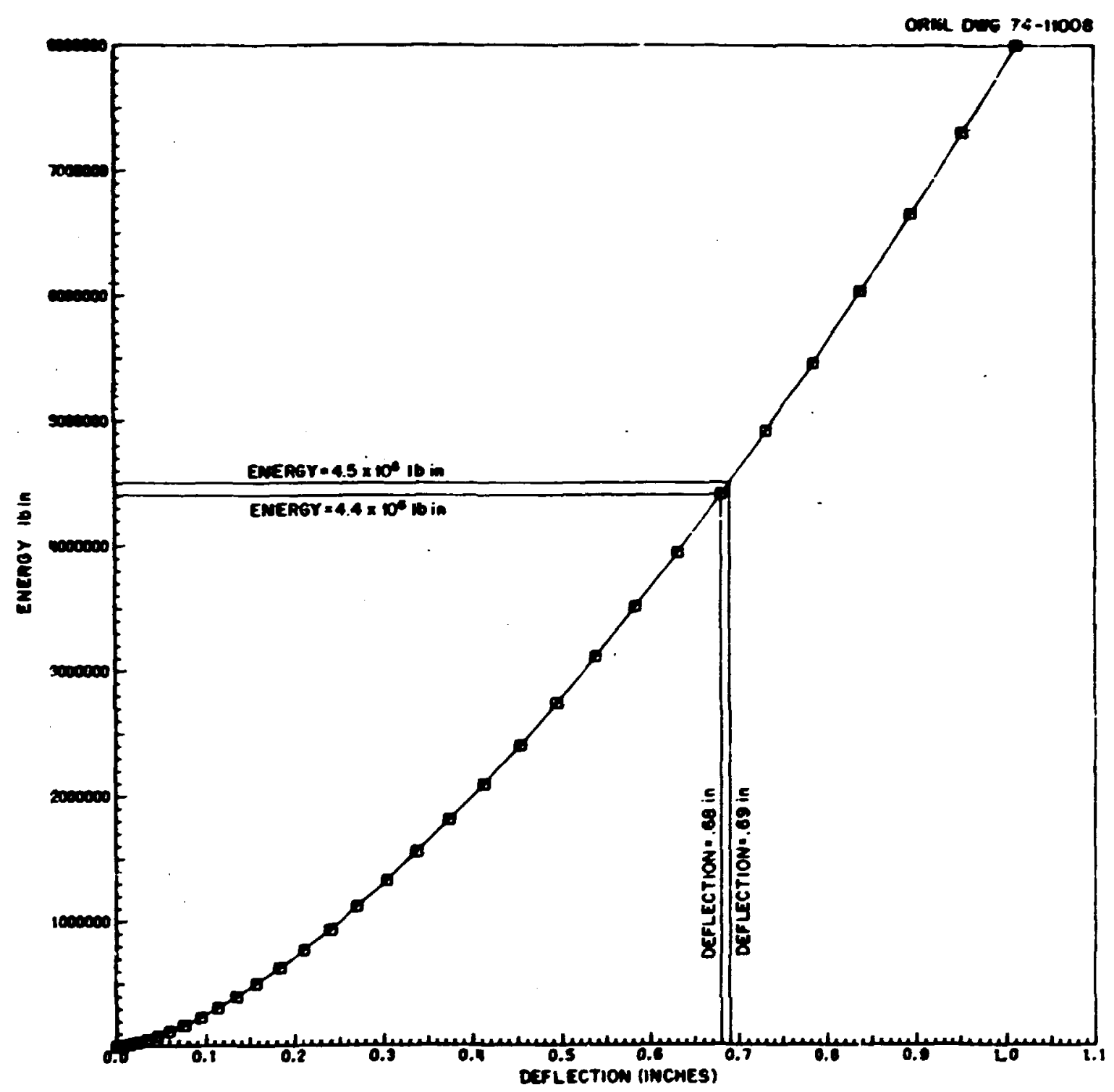

F1g. 1.28. Sjde-drop dynamic yield stress $=14,000 \mathrm{psi}$. 


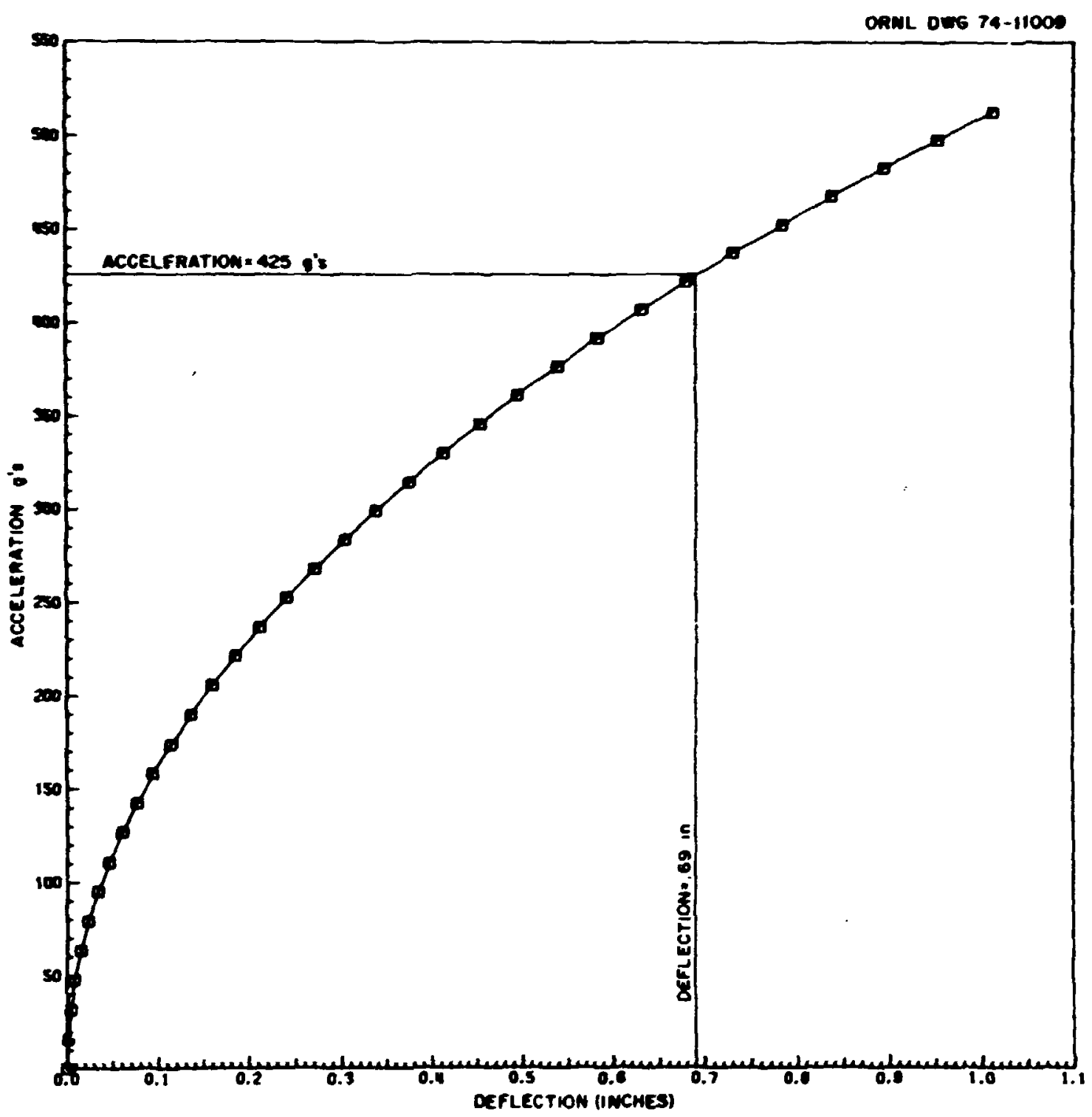

Fig. 1.29. Side-impact dynamic yield stress $=14,000 \mathrm{psi}$. 


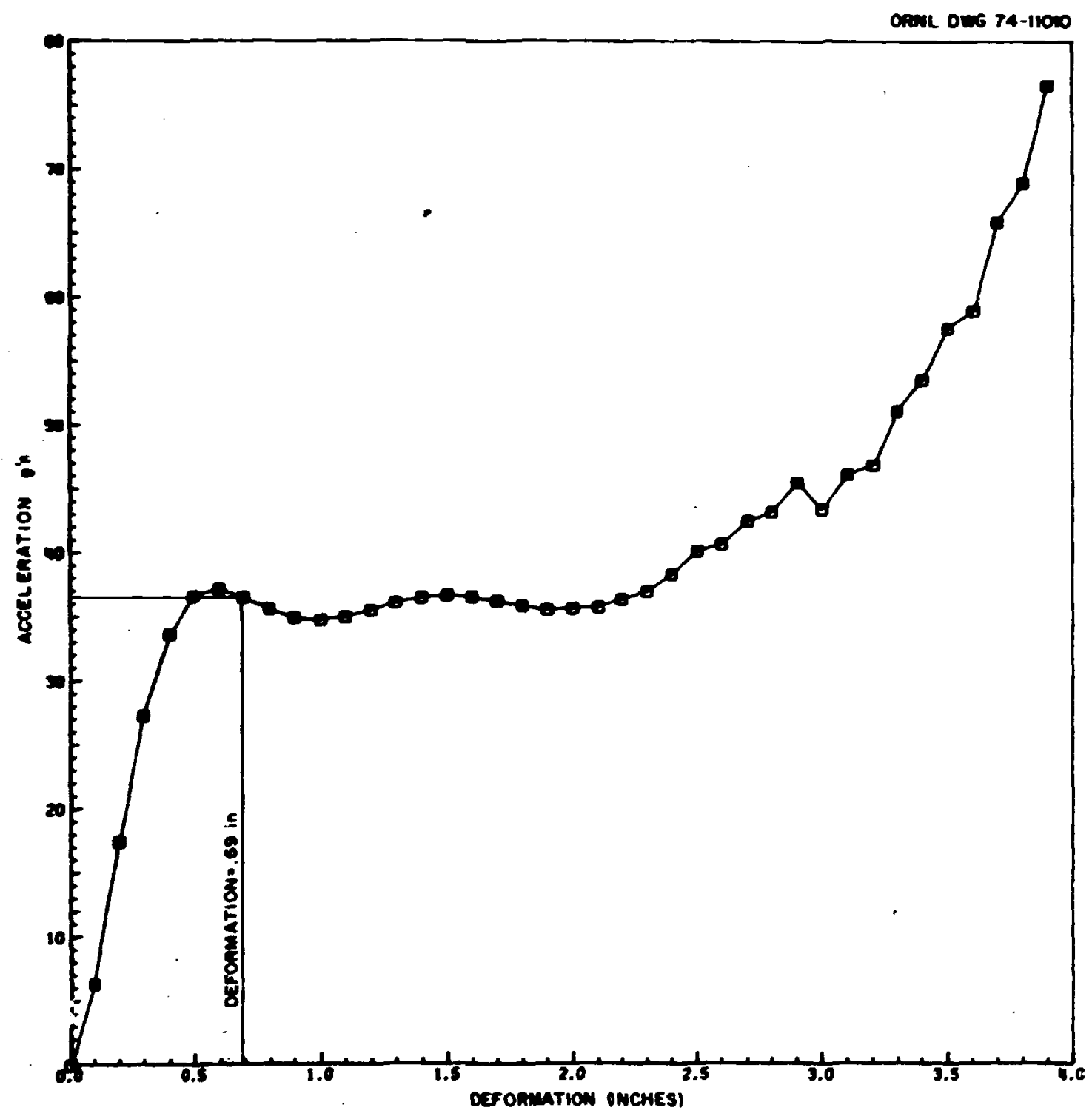

F18- 1.30. Side-impact response of two pipes. 


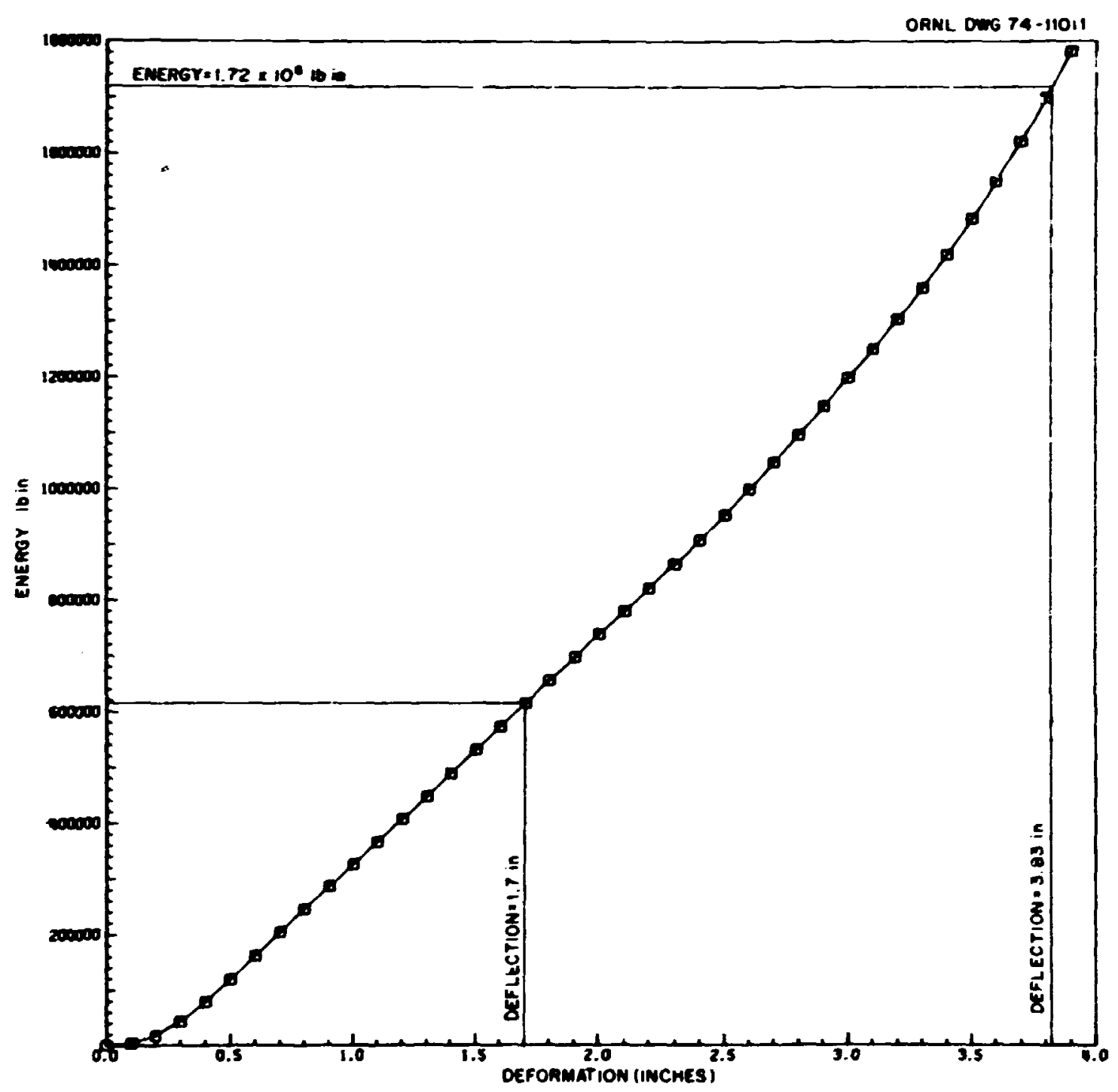

F1g. 1.31. Energy deflection curve for one pipe. 
By comparison with Sect. 4, it is concluded that the calculated local reduction in shielding of $1.19 \mathrm{in}$. would not result in radiation doses in excess of those allowable. For the peak calculated acceleration of $462 \mathrm{~g}^{\prime} \mathrm{s}$, the plug would exert a dowmard force on the tapered seating surface (Fig. 1.32). The agnitude of this vertical for:e $F_{p}$ is found fron Newton's law

$$
F_{P}=W a / g=2300(462 \mathrm{~g}) / \mathrm{g}=1.06 \times 10^{6} \mathrm{lb},
$$

where

$$
\begin{aligned}
& W=\text { weight of the plug }(1 b), \\
& a=\text { acceleration }\left(g^{\prime} s\right) \\
& g=\text { gravitational constant }
\end{aligned}
$$

This force system acting on the plug is shown in Fig. 1.32. From the sumation of vertical forces, $F_{v}=F_{p}=1.06 \times 10^{6} 1 \mathrm{~b}$. Also,

$$
F_{H}=F_{v} \tan 15^{\circ}=1.06 \times 10^{6} \tan 15^{\circ}=2.84 \times 10^{5} 1 \mathrm{~b} .
$$

The force $F_{B}$ represents the initial bolt load and the force $F_{g}$ the force the plug exerts on the tapered seat per linear in. The reactions $F_{v}$ and $F_{H}$ are taken as concentrated loads, and friction is neglected. The forces $F_{1}$ thru $F_{6}$ are increased bolt load resulting from the dynamic load. By suming moments about $A$, we can write

$$
\sum M_{A}=5.5 F_{P}+21.68 F_{H}+\int y d F_{s}-\sum_{n=1}^{n=7} F_{B} y_{n}-\sum_{n=1}^{n=6} F_{m} y_{n}=0 .
$$

The terms $\int y d F_{s}$ and $\sum_{n=1}^{n=7} F_{B} y_{n}$ are numerically equal and of opposite sign; hence, they may be dropped. If the flanges are considered rigid, the expression

$$
\Delta_{1} / y_{1}=\Delta_{2} / y_{2}=\Delta_{3} / y_{3}=\Delta_{4} / y_{4}=\Delta_{5} / y_{5}=\Delta_{6} / y_{6}
$$


ORNL DWG 74-11897
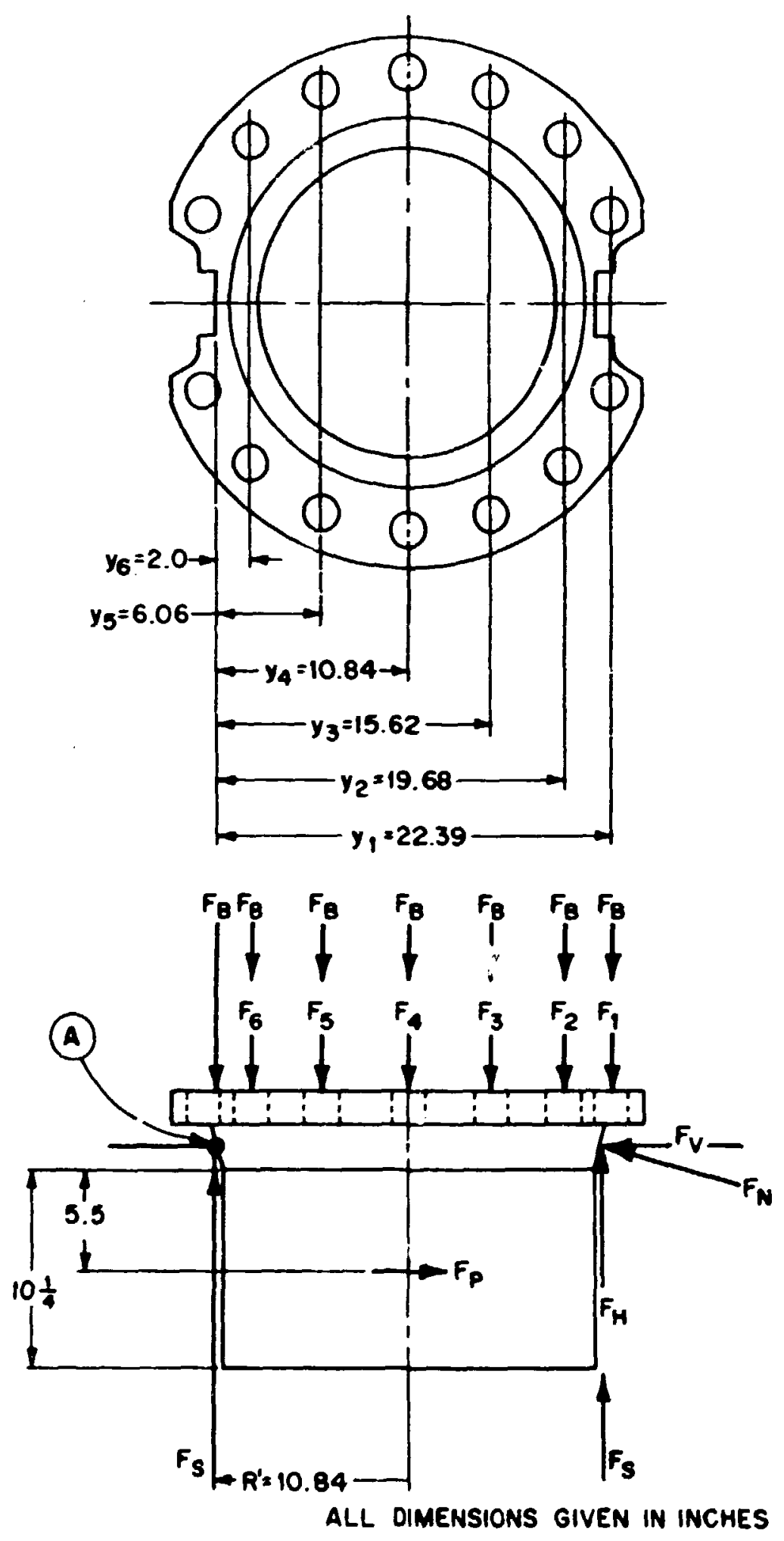

F1g. 1.32. Plug force diagram. 
Is true, $\Delta$ being defined as the elongation in the bolts due to the inertia forces and $y$ as the ment ara (Fig. 1.29) from to the individual bolcs. Also, $F=\Delta E / L$; hence,

$$
F_{1} / y_{1}=F_{2} / y_{2}=F_{3} / y_{4}=F_{5} / y_{5}=F_{6} / y_{6},
$$

and all the forces can be expressed in terns of $F_{6}$. The largest force numerically in the closure bolts is

$$
F_{1}=y_{1} F_{6} / y_{6}
$$

The woment equation now becomes

$$
\sum M_{A}=5.5 F_{p}+21.68 F_{H}-\left(2 F_{6} / y_{6}\right)\left(y^{2}+y_{2}^{2}+y_{3}^{2}+y_{4}^{2}+y_{5}^{2}+y_{6}^{2}\right)=c .
$$

Substituting known values and solving for $F_{6}$, it is found that

$$
F_{6}=95.6001 b \text {. }
$$

The maximum stress in the $1-1 / 2-1 n$. AIsc4340 studs is

$$
\sigma=F_{\epsilon}^{\prime} A=95,600 / 1.404=68,000 \mathrm{psi} \text {, }
$$

which is below the yield stress for AISC4340 steel in the annealed condition. It is concluded that containment will be maintained during and after the side drop. 
1.5.1.3 Impact on a corner with the point of impact and center of gravity having a vertical axis. If the cask impacted on its top corter, the extended pipes could contact the surface first and detorm. After a maximum deformation of 2 in., the removable carbon steel topenergy absorber would also contact the surface. The magnitude of the pipe deformation depends on the radial orientation. There are some radial orientations in which the absorber would contact the surface first and the pipes would absorb energy in a secondary fashion. The top-energy absorbe: will deform in compression and absorb energy. Simultaneous with this absorption, energy will be absorbed in the cask body as discussed in Sect. 1.5.1.1.

The response of the pipes in a corner impact cannot be readily calculated from tineory, nor have similar members been tested. Two 1-to2.56 models of an extended pipe energy absorber were fabricated. The model is shown in Figs. 1.33 and 1.34. These models were bolted to the bottom of the variable weight-drop hammer at the ORNL Drop Tower and impact cested to establish their capability for absorbing energy. The first model test was with a hamer weight of 252 lb dropped frcm $30 \mathrm{ft}$. The resulting damage is shown in Fig. 1.35. The model had totally failed, and no conclusion as to the absorber's ability to absorb energy could be reached. The second model was secured to the hamer still loaded with 252 $1 \mathrm{~b}$, hoisted to $10 \mathrm{ft}$, and released. The resulting damage is shown in Fig. 1.36. The measured defiection of the model was 3 in. The absorbed energy $U_{m}=(252)(120)=3.02 \times 10^{4} \mathrm{in} \cdot \cdot 1 \mathrm{~b}$. The energy $U^{1}$ applicable to one fullsized absorber would be $U^{1}=U_{m}(S F)^{3}=3.02 \times 10^{4}(2.56)^{3}=5.45 \times 10^{5}$ in.-1b. The deformation associated with a full-size absorber would be $(2.56)(3.0 \mathrm{in}$.) $=7.7 \mathrm{in}$. This is small compared with the total potential energy of the cask at $30 \mathrm{ft}$, which is $8.28 \times 10^{6} \mathrm{in} \cdot \cdot 1 \mathrm{~b}$. Since the energy absorbed by the pipes is small compared with the potential energy and there is uncertalnty as to the radial orientation of the cask during impact, the energy absorbed by the pipes will be neglected. This is a conservative assumption.

The top-energy absorber and the cask body must, therefore, be capable of absorbing all the cask's kinetic energy. The program CEIR ${ }^{20}$ was 
ORNL DWG 74-9654

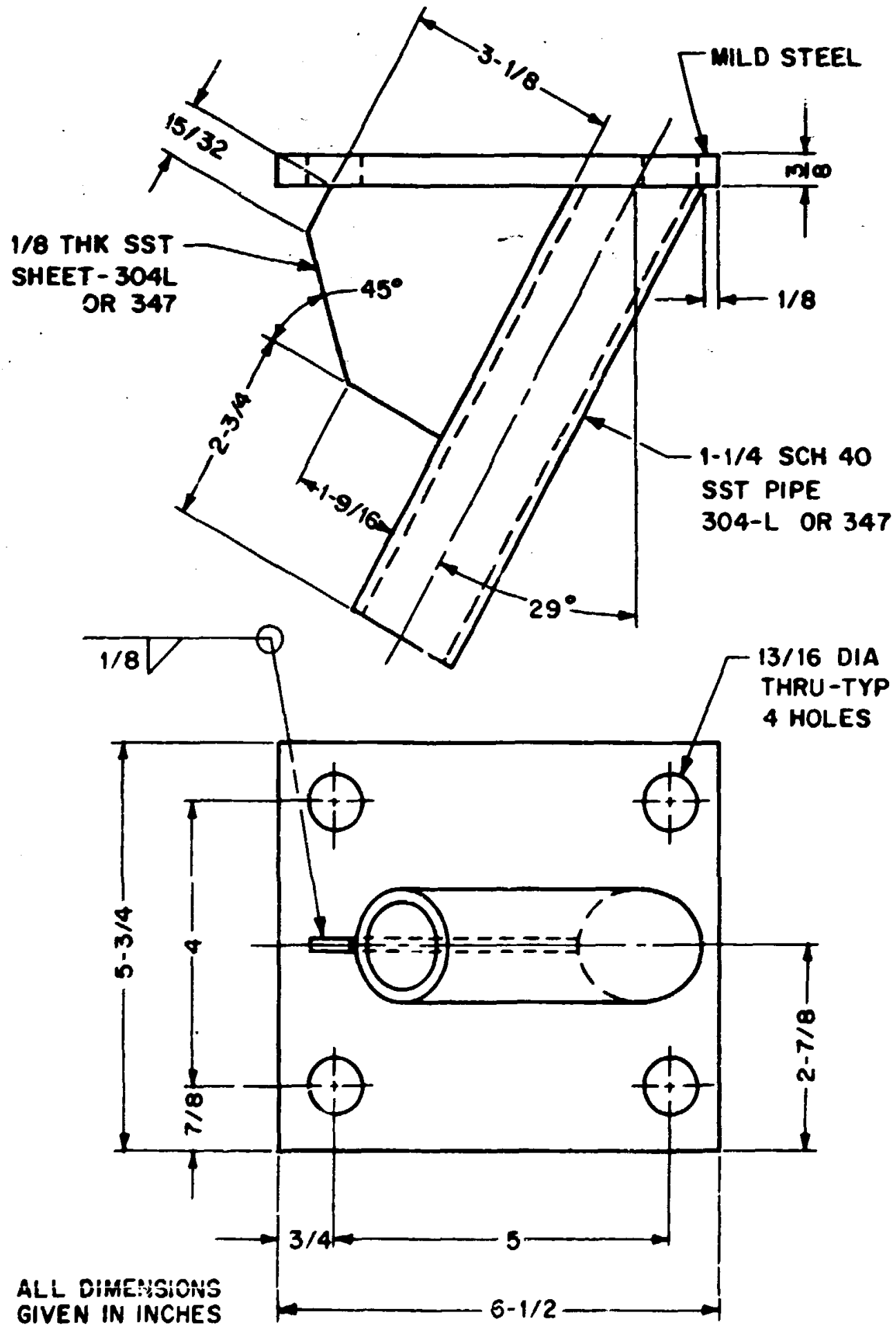

Fig. 1.33. Corner-impact model. 


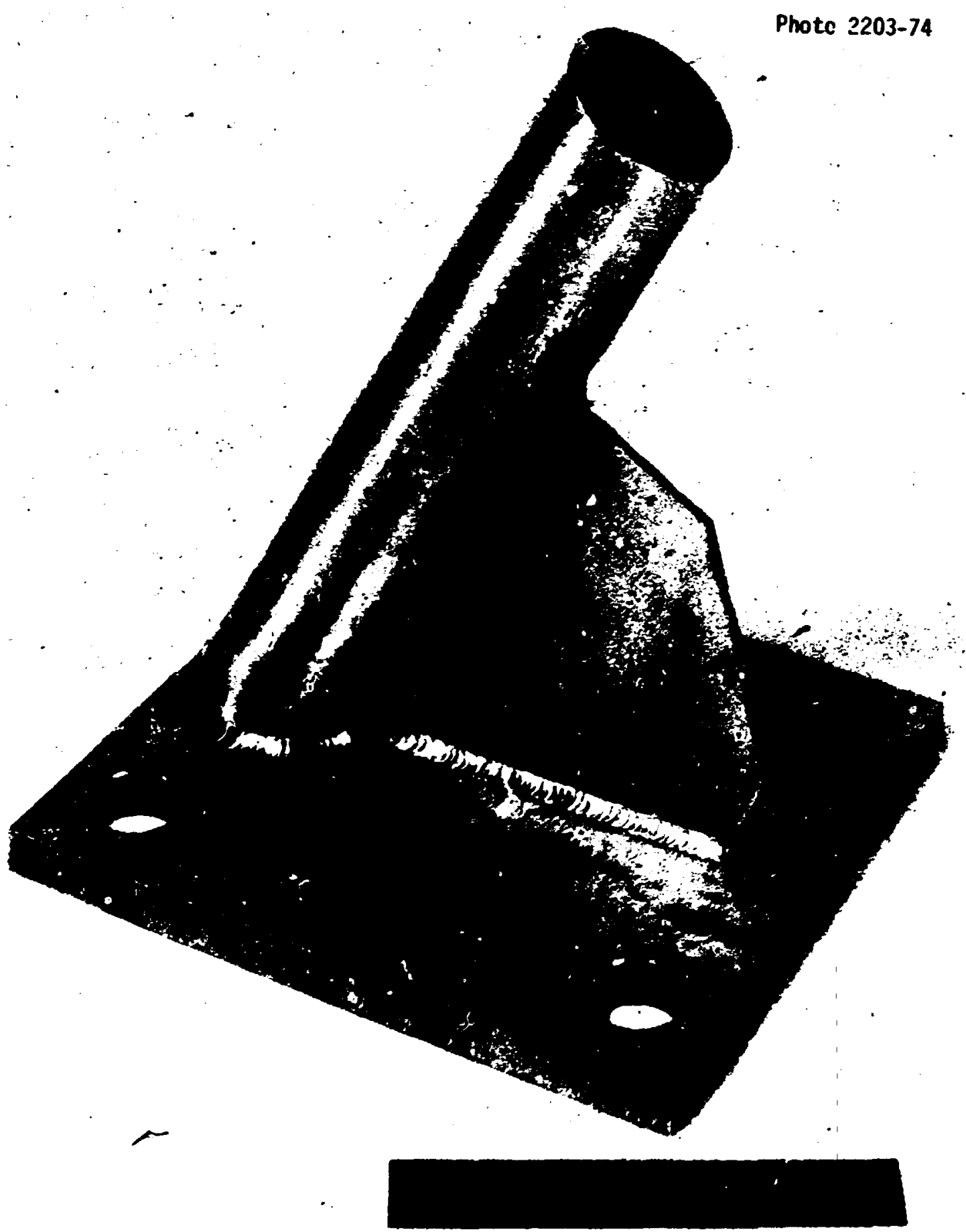

Fig. 1.34. Corner-impact model. 


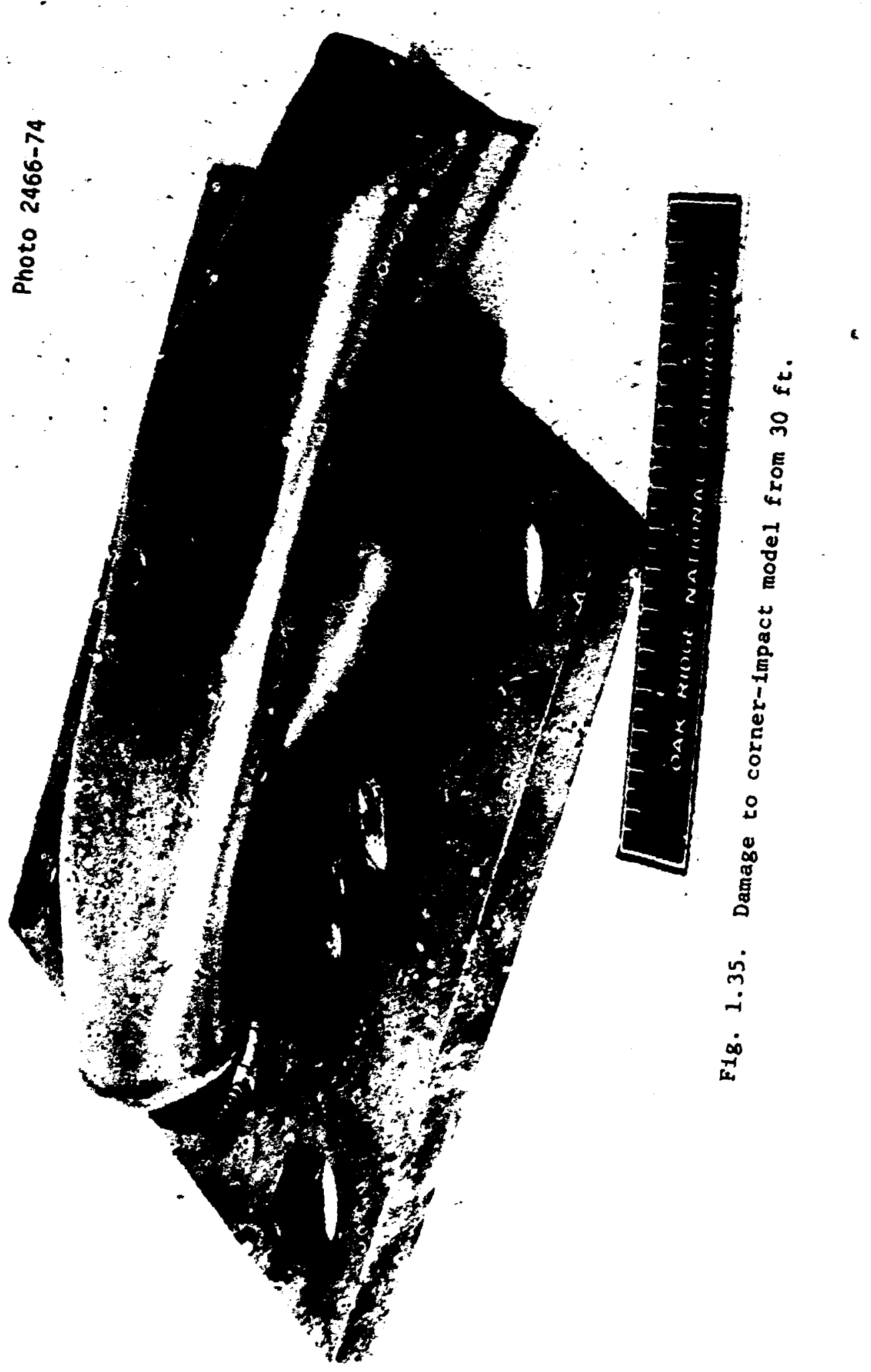




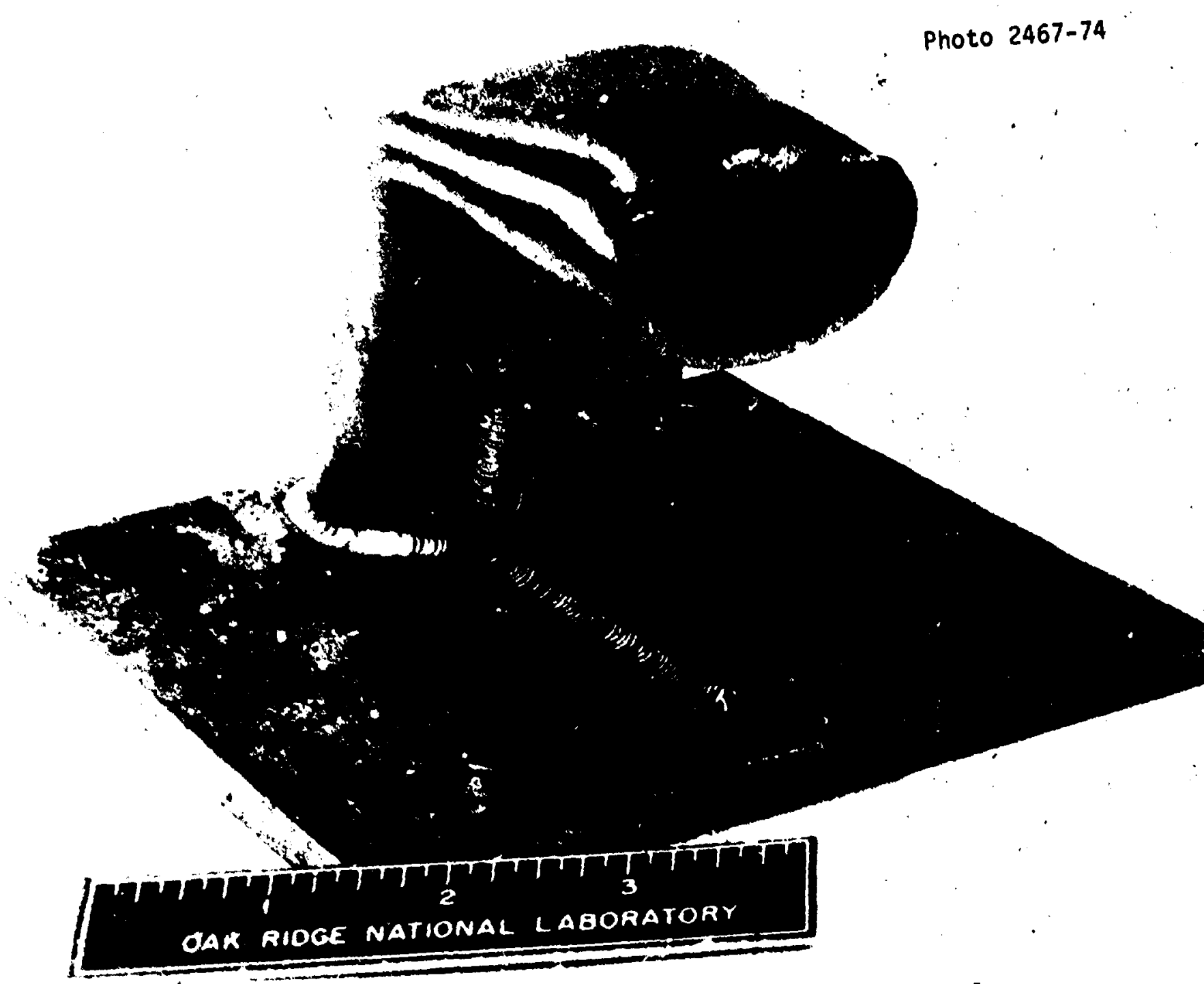

Fig. 1.36. Damage to corner-impact model from $10 \mathrm{fc}$ 
modified to calculate the quantity of the energy absorbed relative to the axial component, $a^{\prime}$, of the cask's acceleration. The equation $a^{\prime}$ $=a(\cos \theta)$, where a is the acceleration of the cask along the line of impact and $\theta$ is the angle the cask axis forns with the vertical, was used to accouplish this.. The energy absorbed in the top-energy absorber was calculated using the progran 1015 CAST. This progran uses plastic deformation theory ${ }^{16}$ to calculate the energy absorbed in a ring-type absorber falling in compression. The derivations of equations and progran listing are show in Appendix $F$. It 18 noted that the absorber is designed 80 that the exjority of the defornation occurs in the uppernost $4 \mathrm{In}$. (F18. 0.1 and Appendix A, F18. A.12). For this calculation it is assuned that al: the.deformation occurs in this portion of the absorber. Figure 1.37 is a machine plot of acceleration vis energy absorbed in the cop absorber as calculated using 1015 CASR; and F18. 1.38 is a similar plot for the energy absorbed in the cask body calculated using CEIR. By trial and error, it was found that when the cask's acceleration reached 1398 's (F1g8. 1.37 and 1.38), a quantity of energy equal to the cask's potential energy had been absorbed and the cask had come to rest. From P1g. 1.39, a wachine plot of the deformation of the shielding vs acceleration as computed using $\operatorname{CBIR}^{20}$, it can be seen that the shielding deformation will reach $1.26 \mathrm{in}$. From $\mathrm{FIg} .1 .40$, a machine plot of the deformation top absorber vs acceleration, it can be seen that the absorber w111 deform $2.38 \mathrm{in}$.

The axial acceleration is

$$
\begin{aligned}
a^{\prime} & =a \cos \theta=139 \cos \left[\tan ^{-1}(D / L)\right] \\
& =139 \cos \left[\tan ^{-1}(37.5 / 72)\right]=123 \mathrm{~B} .
\end{aligned}
$$

The inertia force $F$ applied to the plug bolting is

$$
\begin{aligned}
F & =m_{a}=W_{P}=2100(123) \\
& =2.58 \times 10^{5} 1 b .
\end{aligned}
$$




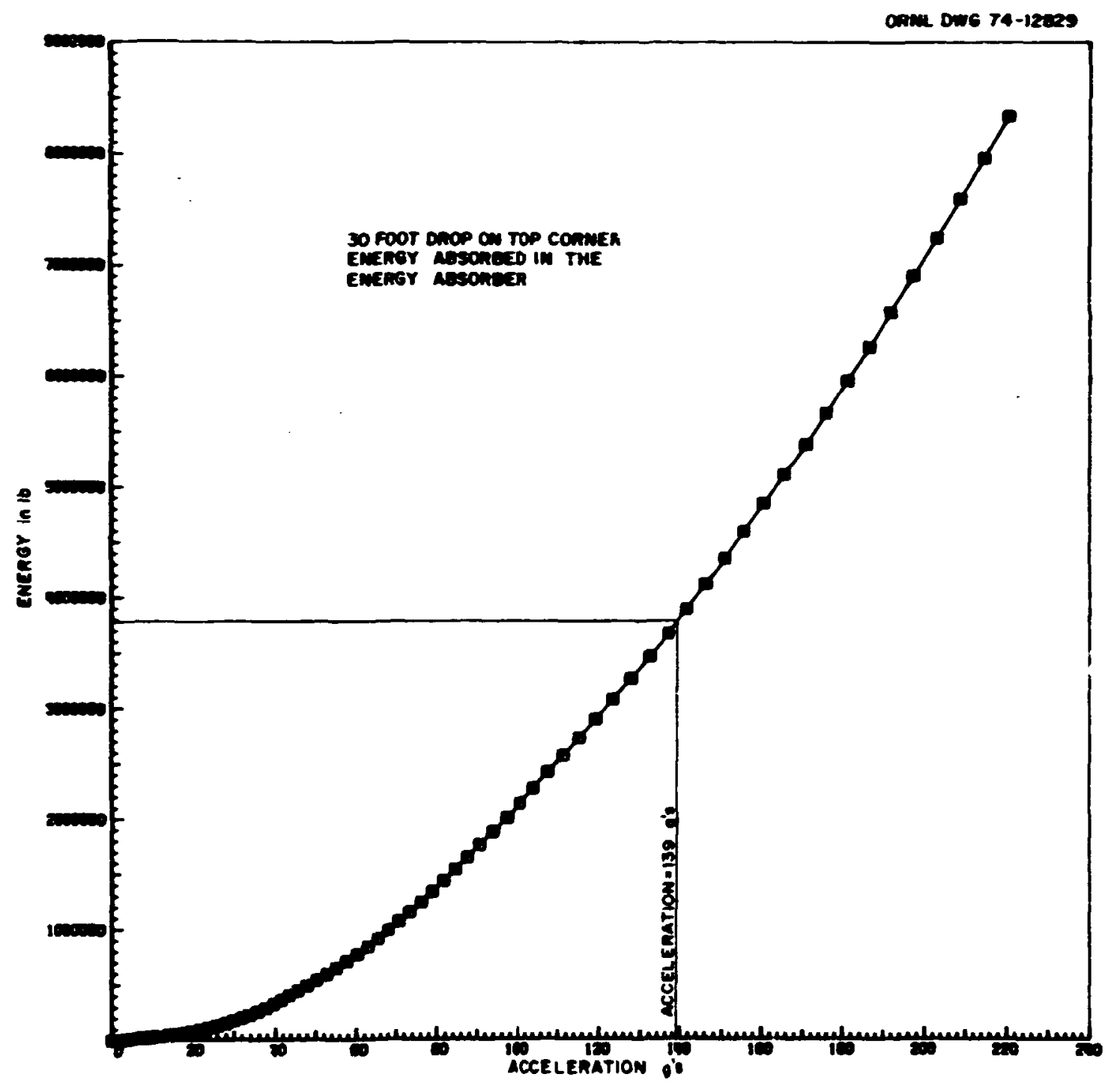

F18. 1.37. Corner 1mpact - energy absorber. 
78

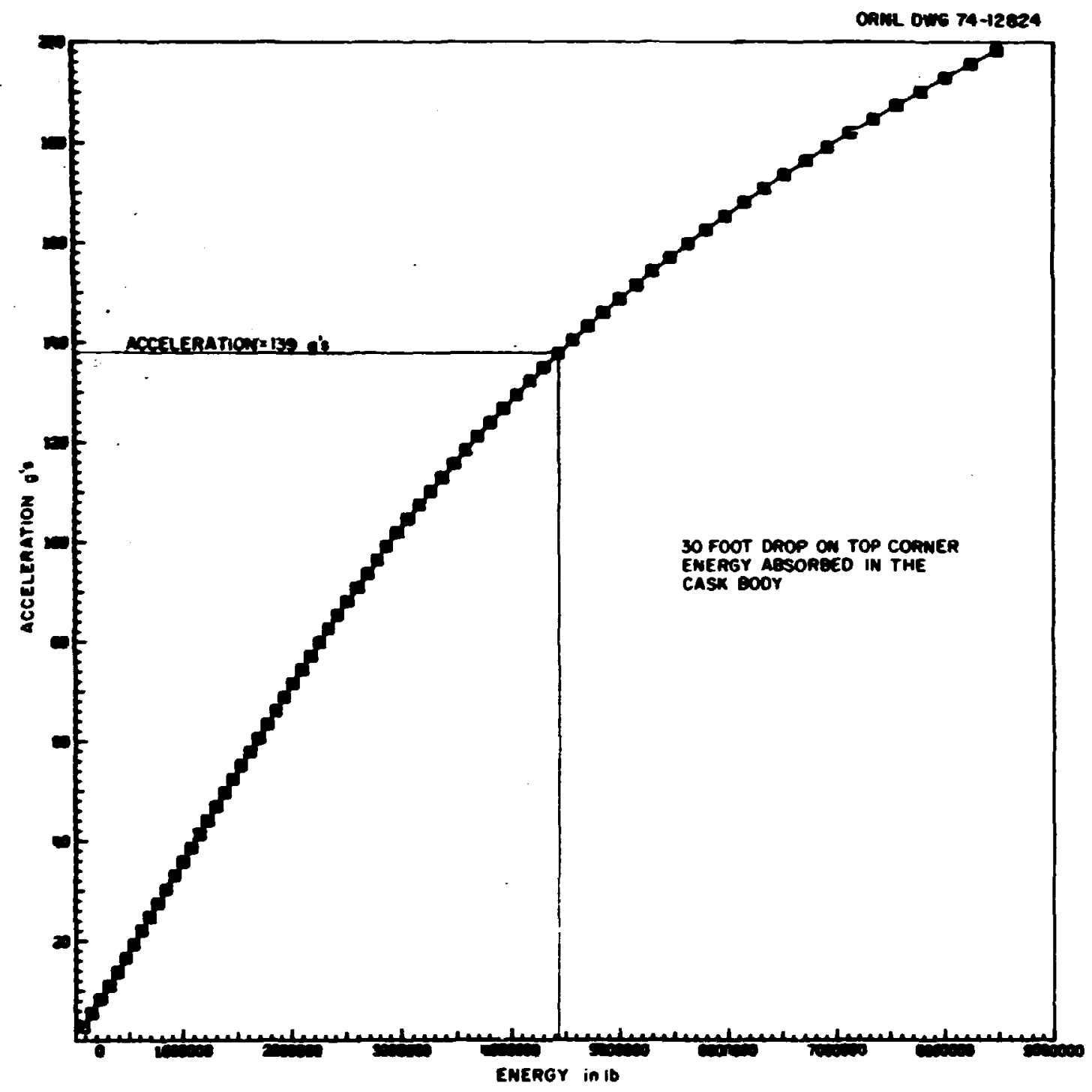

Fig. 1.38. Corner Impact - cask body. 


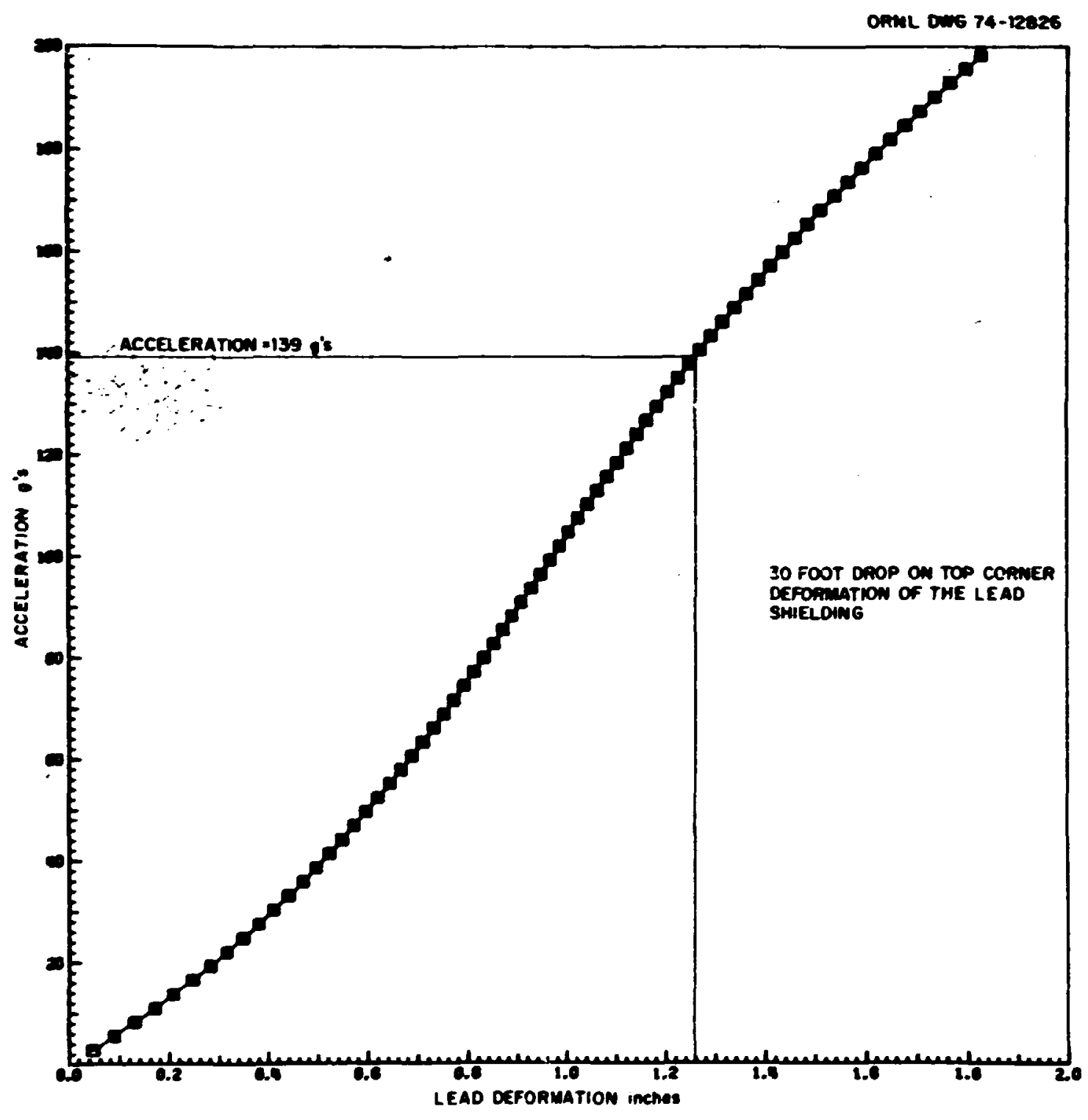

Fig. 1.39. Corner impact - shielding deformation. 


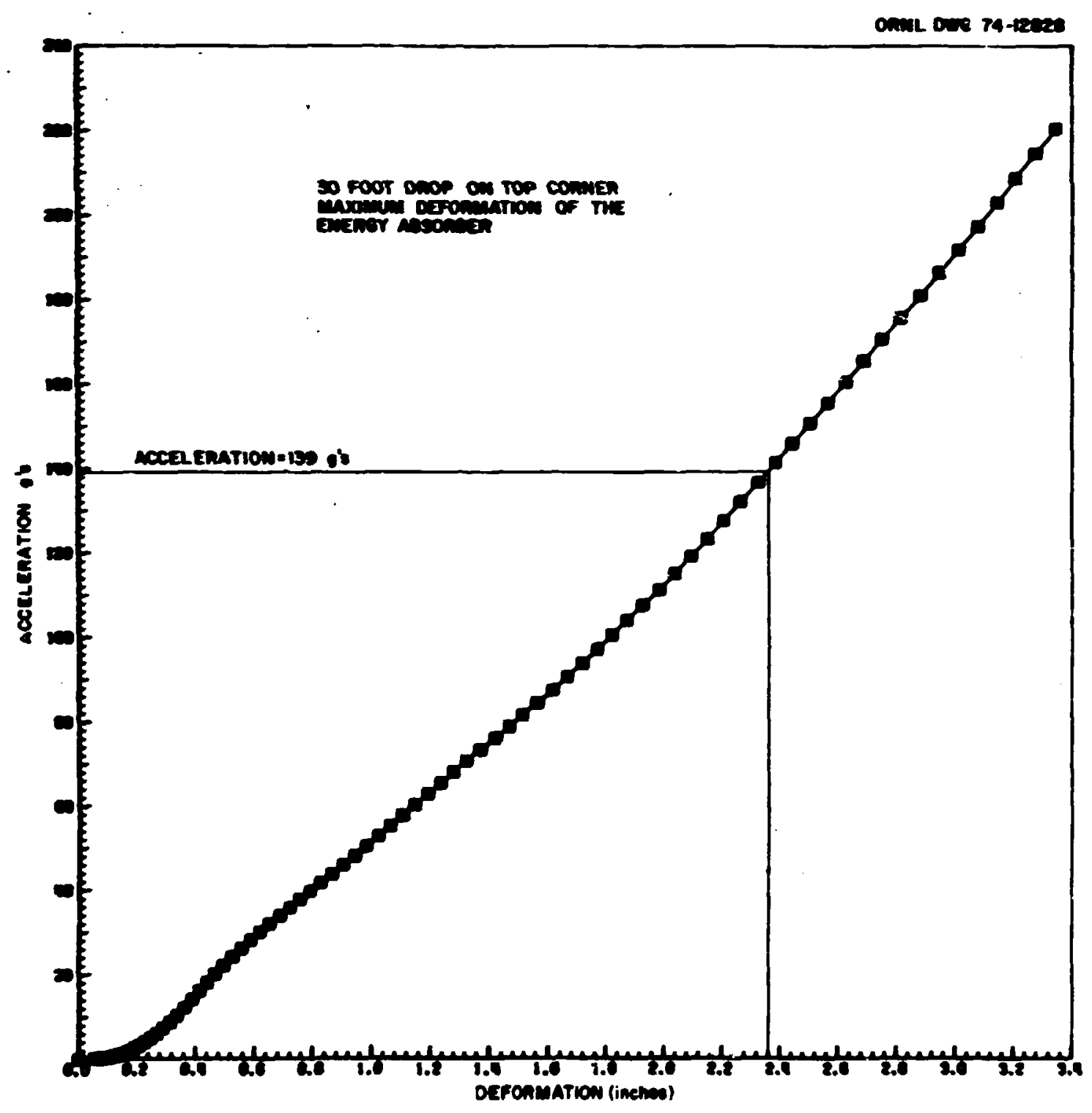

F1g. 1.40. Corner Impact - absorber deformation. 
where

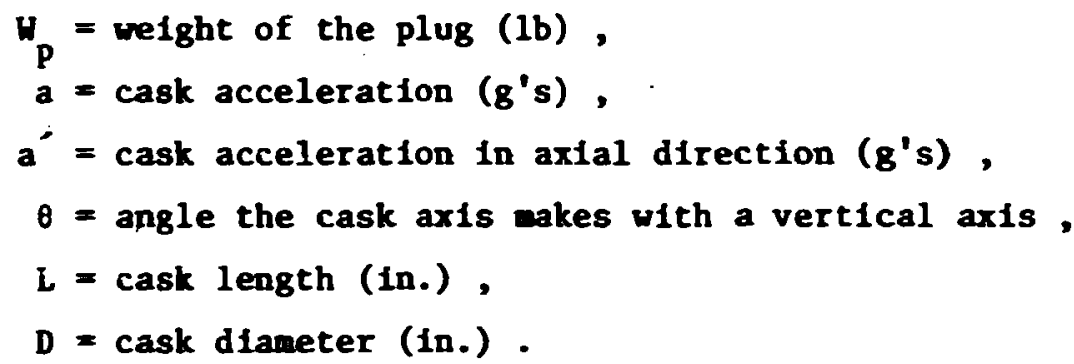

The censile stress $\sigma$ in the closure bolting is

$$
\sigma=F / A N=2.58 \times 10^{5} / 1.4(14)=13,200 \mathrm{ps} 1
$$

Since this is below yield stress, the bolts will not fall in tension and the plug will be retained. The transverse load will be small when compared with the force in the side drop.

\subsubsection{Puncture}

The second in the sequence of hypothetical accident conditions to which the package must be subjected is a free drop through a distance of $40 \mathrm{in.} \mathrm{to} \mathrm{strike} \mathrm{in} \mathrm{a} \mathrm{position} \mathrm{in} \mathrm{which} \mathrm{maximum} \mathrm{damage} 18$ expected, the top end of a vertical cylindrical mild-steel bar mounted on an essentially unyieldirig horizontal surface. The mild-steel bar shall have a diameter of $6 \mathrm{in}$. with the top horizontal and 1 ts edge rounded to a radius of not more than $1 / 4 \mathrm{In} .$, and the bar shall be of such length that it w11 cause maximum damage to the cask but shall not be less than 8 in. long. The long axis of this bar shall be normal to the surface of the cask upon Impact.

The sides (cylindrical surfaces) and bottom of the cask are partially protected (from the 6-in. bar) by the 4-in. schedule 80 pipe heat-tranyfer fins. The 1/2-in. shell and bottom head are, however, adequate to resist puncture without this protection. Data by Nelms 23 (F1g, 23, Nelms' report) Indicate that one 1/2-in. cylindrical facket of a material having an ultimate tenalle atrength of 75,000 pal would not puncture under a cask weight of 23,000 1b. Similar data by Spaller ${ }^{24}$ for flat plates indicate 
that a 1/2-in. botton plate of type 347 stainless steel would not puncture for the specified test condition and the HFIR cask geometry.

If the cask impacted on the top, protection would be afforded by the 1-in.-thick plate in the top-energy absorber. The acceleration would be less than in those examples previously considered.

\subsection{Containment Vessel Design Pressure}

The containient vessel is shown in simplified form in Fig. 1.41. The allowable or design pressure for the vessel is established by using the equations, design stress values, and philosophies of Sect. VIII of the ASME Code 26. The contribution of local shfelding and, in the case of the top head, the internal heat transfer surfaces (connectors) will be neglected in the interest of computational simplicity. It can be determined by inspection that the plug or top head will be the component which limits the allowable pressure. Equation (1) of paragraph UC-34 of the Code considers a case in which $S$ is equal to 16,400 psi (Table UHA 23 of Code), the temperature does not exceed $300^{\circ} \mathrm{F}$, and the plate is of type 347 stainless steel. From Table 2.2, the normal operating temperature of the vessel is below this value for the condition of $130^{\circ} \mathrm{F}$ in bright sunlight; therefore,

$$
P=S t^{2} / d^{2} C=16,400(0.5)^{2} /(20)^{2}(0.3)=34.2 \mathrm{psi}
$$

At this pressure the load on the plug is

$$
F=\pi d^{2} / 4(P)=\pi(20)^{2} / 4(34.2)=10,7401 b .
$$

When distributed to the 14 studs securing the core, this load is small and well within the load tolerance.

\subsection{Thermal and Thermal Expansion Stresses}

The HFIR cask is subjected to internal and external sources of heat. The thermal stresses and stresses wh. ch result from differential expansion of $f$ dissimilar materials are evaluated below. 


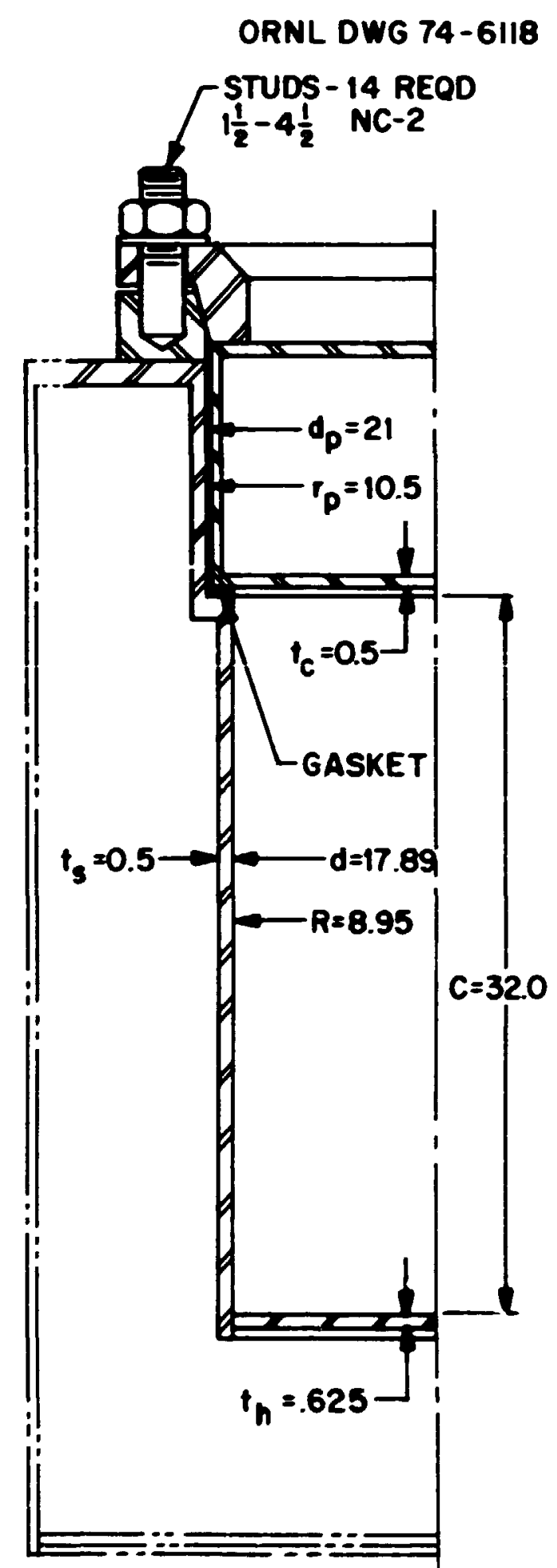

ALL DIMENSIONS GIVEN IN INCHES

Fig. 1.41. Containment vesse1. 


\subsubsection{Nornal conditions of transport}

The tenperature gradients (Sect. 2) which result from the internal and normal solar heat loads are not sufficient to cause significant thermal or expansion stresses.

\subsubsection{Accident conditions}

As above, the thermal gradients are not sufficient to cause significant thermal stresses. Differential expansion of the solid and melted lead will result in significant expansion stresses. Because the expansion of lead is greater than that of stainless steel, the heated lead will strain the she11. In calculating this strain, the volume of melted lead shown in Fig. 1.42(a) was wodeled as shown In Fig. 1.42(b). Using Fig. 2.3 as a $k e y$, the peak temperatures at various points in the cask were read from Figs. 2.5 and 2.6. From this information, the following average temperatures were computed:

$\begin{array}{ll}\text { Air in the plug void } & 585^{\circ} \mathrm{F} \\ \text { Melted lead } & 621^{\circ} \mathrm{F} \\ \text { Unmelted lead in plug } & 585^{\circ} \mathrm{F} \\ \text { Unmelted lead in main cavity } & 565^{\circ} \mathrm{F} \\ \text { Inside of steel shell of plug } & 750^{\circ} \mathrm{F} \\ \text { Main steel shell } & 800^{\circ} \mathrm{F}\end{array}$

The fabrication conditions were taken to be $70^{\circ} \mathrm{F}$ and $14.7 \mathrm{psia}$. The void volume that exists is approximately 5/16 in. wide and is shown on the engineering drawings in Appendix A.

In the plug, the cavity volume inside the steel jacket before the fire 18

$$
\mathrm{V}_{\text {SST }}=2831.3 \mathrm{in.} .^{3}
$$

and the volume of the lead before the fire is

$$
v_{\mathrm{Pb}}=2734.2 \mathrm{in.}^{3}
$$


ORNL DWG 74-9652

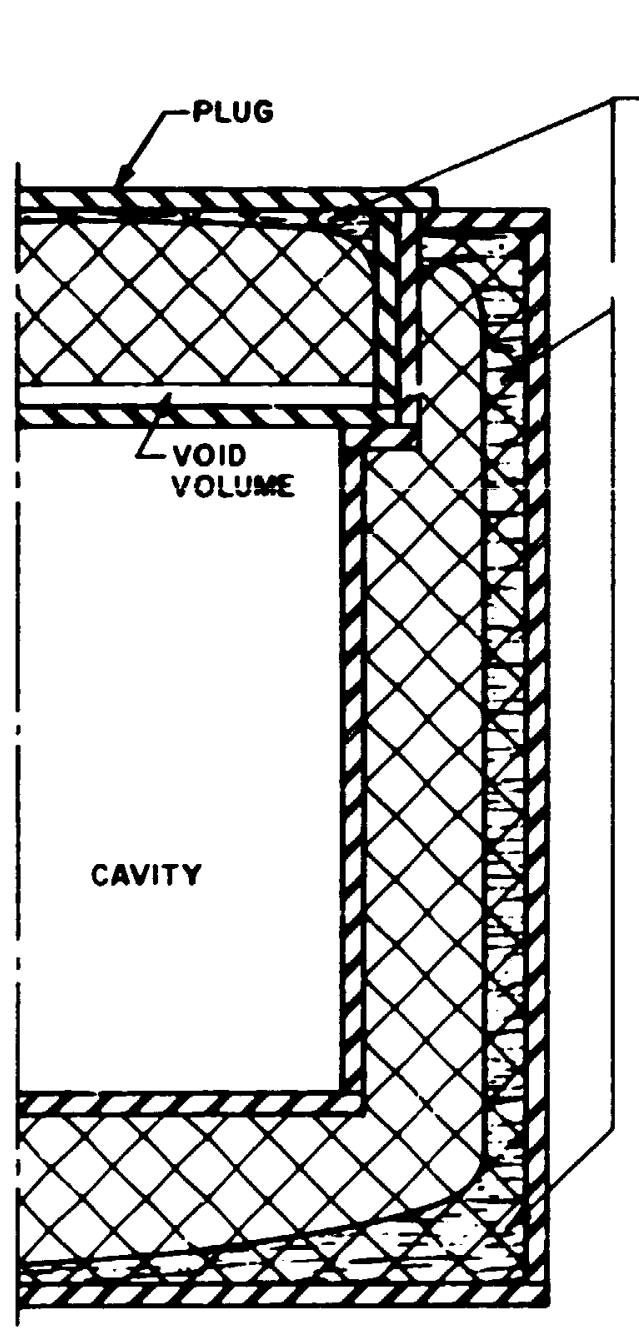

(a)

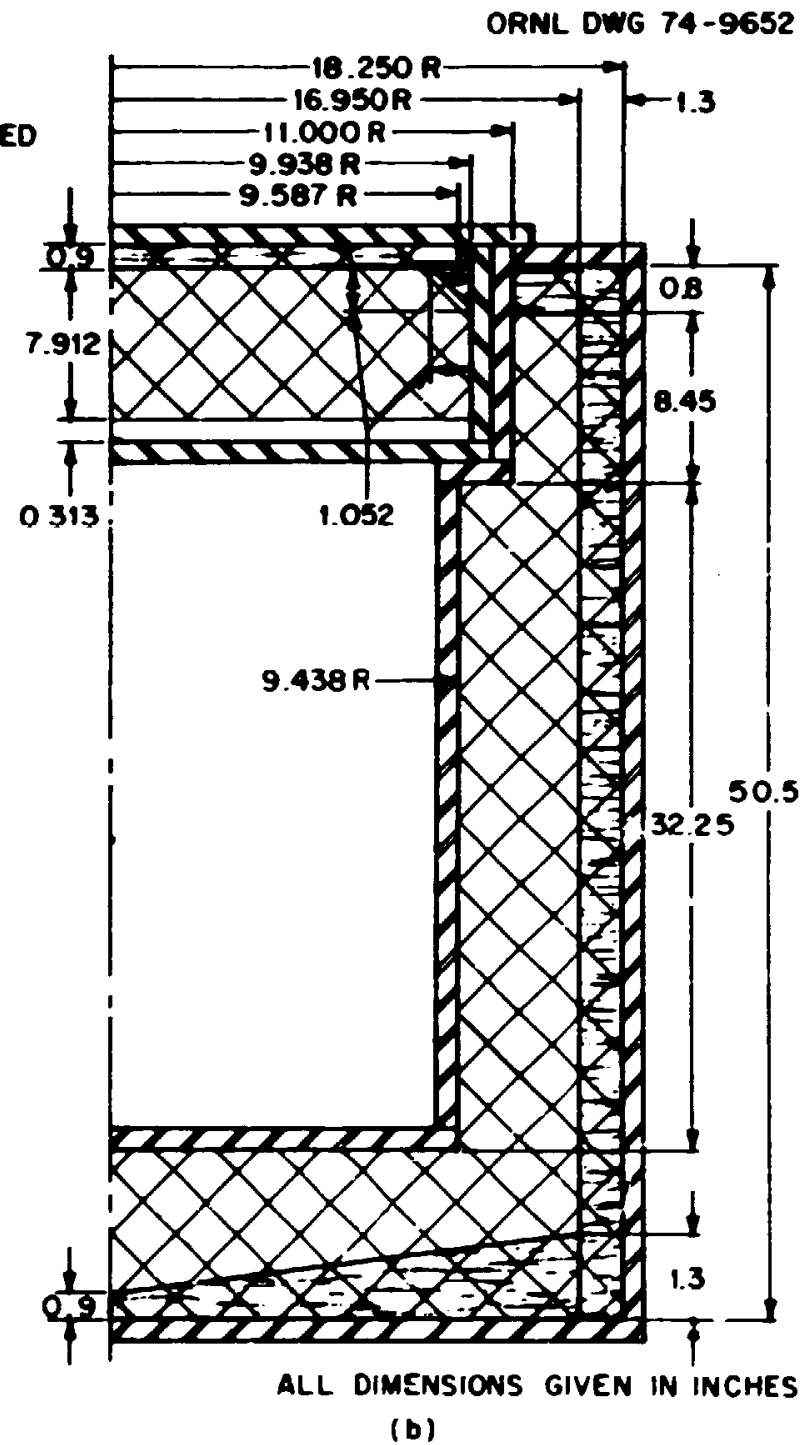

Fig. 1.42. Diagram of lead melt. 

where

$$
\begin{aligned}
& \mathrm{P}=\text { pressure, } \\
& \mathbf{V}=\text { volume, } \\
& \mathrm{T}=\text { temperature (absolute). }
\end{aligned}
$$

For the air in the void,

$$
\begin{aligned}
& \mathrm{v}_{1}=\mathrm{v}_{\mathrm{SST}}-\mathrm{v}_{\mathrm{Pb}}, \\
& \mathrm{v}_{2}=\mathrm{v}_{\mathrm{SST}}^{\prime}-\mathrm{v}_{\mathrm{Pb}}, \\
& \mathrm{P}_{1}=14.7 \mathrm{ps} 1 \mathrm{a}, \\
& \mathrm{T}_{1}=70^{\circ} \mathrm{F}=530^{\circ} \mathrm{R}, \\
& \mathrm{T}_{2}=585^{\circ} \mathrm{F}=1,045^{\circ} \mathrm{R} .
\end{aligned}
$$

Hence,

$$
\begin{aligned}
P_{2}= & \left(T_{2} / T_{1}\right)\left(V_{1} / V_{2}\right)\left(P_{1}\right)=(1,045 / 530)(2831.3-2734.2) /(2887.1- \\
& 2813.9)(14.7) \\
= & 38.5 \mathrm{psi} .
\end{aligned}
$$

The hoop stress in the plug is

$$
\sigma=p r_{1} / t
$$

where

$$
\begin{aligned}
& r_{1}=\text { the inner radius of the vold, } \\
& t \text { - the thickness of the vold wall } \\
& \sigma=38.5(9.938) / 0.5=764.0 \mathrm{pel} \text {. }
\end{aligned}
$$

Th1s strese is far lese than the allowable. 
In the main body of the cask, the volune ji the lead-filled cavity betiore heating is

$$
\begin{aligned}
\nabla_{\text {SST }} & =\left[\left(18.2 .5^{2}\right) 50.5-\left(11^{2}\right) 9.25-9.438^{2}(32.25)\right] \pi \\
& =40,300 \mathrm{in.}^{3} .
\end{aligned}
$$

- After expansiot, the volune of the cavity forwed by the steel 18

$$
\begin{aligned}
V_{S S T}^{\prime} & =\nabla(1+a \Delta T)^{3} \\
& =40,300\left[1+9.6 \times 10^{-6}(800-70)\right]^{3} \\
& =41,153 \mathrm{in.}^{3} .
\end{aligned}
$$

The volume of the expanded lead is

$$
\begin{aligned}
V_{P b}^{\prime} & =V_{m}(1+B)+V_{u}(1+a \Delta T)^{3} \\
& =8,73 i(1+0.062)+31,329\left[1+16 \times 10^{-6}(565-70)\right]^{3} \\
& =41,352 \mathrm{in.}^{3},
\end{aligned}
$$

where $v_{g}$ and $v_{u}$ are calculated from dimensions given In Fig. 1.42 as follows: -

$$
\begin{aligned}
v_{m}= & \pi\left[\left(18.25^{2}-16.95^{2}\right)(50.5)+\left(16.95^{2}-11^{2}\right)(0.8)+\left(16.95^{2}\right) 1.3\right] \\
& -[0.5(1.3-0.9)(16.95)][(2 \pi)(16.95 / 3)] \\
& =8730.8 \mathrm{in.}^{3} . \\
v_{u} & =v_{\text {sST }}-v_{m}=40,300-8,731=31,569 \mathrm{in.}^{3} .
\end{aligned}
$$

Because of the restraining effect of the external pipes, it is resoonable to assume that the resulting longltudinal strain in the outer sheli w11 be negligible when compared with the resulting radial otrain. Further, 
one may conservatively assume that the inner shell and unmelted lead form a radially unyielding inner wall. Thus, radial strain of the outer shell must compensate for differential volumetric growth between the lead and its container as the temperature rises. First, it is assumed that the expanded lead volume is equal to the expanded and stretched volume contained by the steel shell.

$$
V^{\prime}{ }_{\mathrm{Pb}}=\mathrm{V}^{\prime \prime} \mathrm{SST} \text {. }
$$

Since vclume is directly proportional to the square of the radius,

$$
\frac{R^{\prime \prime 2}}{R^{\prime 2}}=\frac{V^{\prime \prime}}{V^{\prime} S S T},
$$

where

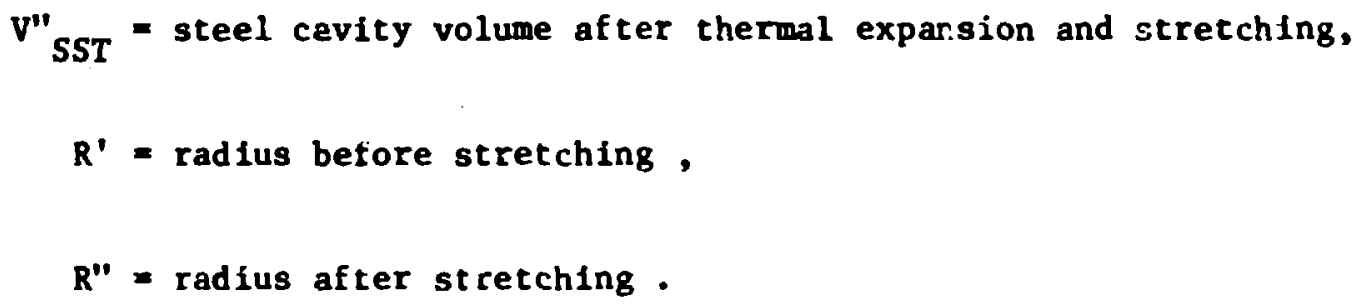

The radius before and after is related by the amount of strain which the shell undergoes,

$$
\mathbf{R}^{\prime \prime}=\mathbf{R}^{\prime}(1+\varepsilon) \text {. }
$$

Therefore,

$$
\left[R^{\prime}(1+\epsilon)\right]^{2 / R^{\prime 2}}=V^{\prime \prime}{ }_{S T T} / V^{\prime}{ }_{S T T} .
$$

The radius terms cancel, leaving

$$
\begin{aligned}
(1+\varepsilon) & =(41,352 / 41,153)^{1 / 2} \\
\varepsilon & =0.0048 \mathrm{in} . / \mathrm{in} .
\end{aligned}
$$


Strains of this eagnitude do not appraach even the roow-temerature ultinate strains of 347 stainless steel and thus are not serfous.

\section{ThEmen EVALDATIOA}

\section{I Discuseion}

- The package wust be able to withstand direct sunlight at an ambient temperature of $130^{\circ} \mathrm{P}$ in still air vithout reducing the effertiveness of the packaging. The regulations 5 set forth by the DOT also stipulate that the tewprature of any accessible surface of the fully loaded shipping parkage shall not exceed $122^{\circ} \mathrm{F}$ when the package is in the shade in st11l alr at an abient temperature assumed to be $100^{\circ} \mathrm{F}$ for this evaluation. Purtber, if the package is transported in a transport vehicle consigned for the sole use of the shipper, the maximum surface temperat"re shali not exceed $180^{\circ} \mathrm{F}$. This confition applies to the HFIR cask since it is always shipped in a closed, sealed highway trailer.

The third in the sequence of hypothetical accident conditions specified by the regulations to which the cask must be subjected is exposute for $30 \mathrm{~min}$ to a source of radiant heat having a temperature of $14.75^{\circ} \mathrm{F}$ and an emissivity coefficient of 0.9 or equivalent. For calculational pu:peses, it shall be assumed that the package has an absorption coefficient of 0.8 . The package shall not be cooled artifically until after the 30-min test period has expired and the temperature at the center of the package has begur to fall.

A computer program, HEATING-3,17 applicable to the IBM 360 computer, was modified to evaluate phase change of materials and was used to determine the temperature distribution, quantity, and location of material which had undergone a change of phase when exposed to a source of heat.

The cask will be used to transport HFIR and the ORR, BSR, PRNCR, and other miscellaneous fuel elements. Thermal calculations were made for the HFIR loading, and for a maximum loading of the ORF type elements. The other elements have significantly lower heat generation rates than these; thus, calculations need not be made. The normal temperature distributions for these loudtage were imilar; hence, an analysis of the fire condition was made only for the HPIR loading. 
The ORIGEN code ${ }^{25}$ was used to compute the decay heat power of the HFIR elements. The Inner element generated $1.18 \mathrm{~kW}$ and the outer element $2.08 \mathrm{kH}$ fcr a tecal of $3.26 \mathrm{~kW}$. The total had previously been calculated by Arr.old ${ }^{2}$ to be $3.31 \mathrm{kH}$. The former values were used in the calculations disci:ssed in preceding pages.

Hamrick ${ }^{26}$ calculated the thermal energy released from ORR (BSR) elements to be $210 \mathrm{~W}$ per element based on an assumed, but conservative, operating cycle (Sect. 0.2 .2 and Appendix D). Total heat load for 17 elements would be $3570 \mathrm{~W}$. The heat load from the geometrically simflar PRNC reactor elenents would be significantly lower than this (Appendix D).

\subsection{Thermal Properties of Materials}

Thermal properties of materials used to compute the temperature distribution and material phase change are listed in Table 2.1 for the HFIR core loading and Table 2.2 for the ORR loading. Emissivity for the cask surf vee was assumed to be 0.6 .

In an enclosed gas space, heat transfer due to natural convection may be significanc. This depends primarily on the $\Delta T$ across the space, the sisface-to-surface spacing of the gas space, and the fluid properties. These parameters are convenfently represented in a dimensionless group called the Rayleigh number ( $R a)$.

$$
R \mathbf{a}=\left(\rho^{2} g B C_{p} / \mu k\right) \Delta T^{3}
$$

The term in parentheses is a grouping of properties of the gas in the gas space, $\Delta T$ is the temperature difference between opposing surfaces of the gas space, and $L$ is the distance between these opposing surfaces.

For values of $\mathrm{Ra}<1000$, internal convection has been experimentally shown to be insignificant, and the heat transfer mechanisms across the gas space are conduction and radiation. For value, of Ra $>1000$, the effect of convection can be simulated using an effective conductivity, ke, for the gas which is larger than the normal molecular conductivity of the 8 as. 
Table 2.1. Material propert1es for HFIR loading

\begin{tabular}{|c|c|c|c|c|c|}
\hline Mater1al & $\begin{array}{c}\text { Temperature } \\
(\cdot \mathrm{P})\end{array}$ & $\begin{array}{c}\text { Theranl } \\
\text { conductivity } \\
\left(\mathrm{Btu} / \mathrm{hr} \cdot \mathrm{ft} \cdot \bullet^{\circ} \mathrm{F}\right)\end{array}$ & $\begin{array}{l}\text { Dewidty } \\
\left(1 \mathrm{~b} / \mathrm{In} .{ }^{3}\right)\end{array}$ & $\begin{array}{c}\text { Heat } \\
\text { capactty } \\
(\Delta t u / 1 b \cdot \bullet)\end{array}$ & $\begin{array}{c}\text { Latane } \\
\text { heac } \\
\text { (Btu/1b) }\end{array}$ \\
\hline Lead ${ }^{a}$ & $\begin{array}{r}0 \\
620 \\
622 \\
1100 \\
1600\end{array}$ & $\begin{array}{r}20.52 \\
17.28 \\
8.50 \\
9.22 \\
16.10\end{array}$ & $\begin{array}{l}0.4113 \\
0.3974 \\
0.3860 \\
0.3766 \\
0.3622\end{array}$ & 0.035 & $\$ 1.3$ \\
\hline $347 \operatorname{sst}^{b}$ & $\begin{array}{r}0 \\
800 \\
1800\end{array}$ & $\begin{array}{r}8.14 \\
11.45 \\
15.72\end{array}$ & $\begin{array}{l}0.286 \\
0.272\end{array}$ & $\begin{array}{l}0.100 \\
0.175\end{array}$ & \\
\hline Aiminume & $\begin{array}{r}a \\
1220\end{array}$ & $\begin{array}{l}110.1 .6 \\
159.84\end{array}$ & 0.0978 & 0.214 & \\
\hline A1r-Aluminum & $\begin{array}{r}0 \\
1220\end{array}$ & $\begin{array}{l}55.44 \\
79.9 ?\end{array}$ & 0.0375 & 0.210 & \\
\hline Puele ${ }^{e}$ & $\begin{array}{r}0 \\
1220\end{array}$ & $\begin{array}{l}41.76 \\
59.76\end{array}$ & 0.0617 & 0.210 & \\
\hline$A d r^{f}$ & $\begin{array}{r}0 \\
250 \\
500 \\
1000 \\
1500\end{array}$ & $\begin{array}{l}0.01312 \\
0.01923 \\
C .02458 \\
0.03370 \\
0.04137\end{array}$ & $\begin{array}{l}0.0000500 \\
0.0000117\end{array}$ & $\begin{array}{l}0.240 \\
0.242 \\
0.248 \\
0.263 \\
0.270\end{array}$ & \\
\hline$A 1 \mathrm{r}-2^{f}$ & $\begin{array}{r}0 \\
1500\end{array}$ & $\begin{array}{l}0.063 \\
0.1656\end{array}$ & $\begin{array}{l}0.0000500 \\
0.0000117\end{array}$ & $\begin{array}{l}0.240 \\
0.270\end{array}$ & \\
\hline
\end{tabular}

${ }^{a}$ For comparable values of theral conductivity of laad see A Compization of Thesmal Proparty Data for Computer Heat-Concuation Calculationo, UCRL-50589 (3969). The apac1Fic heat and the thernal conduct1vIty of lead were obtalned from S. S. Kuteteladze et al. , Liquid Metai Heat Tromefor Media, Chapan 4 Hall, Ltd., London, 1959. The density of lead was obtained from Analyais of HFIR Immadiated Auol slement Shlpping Cask, ORAL-TH-959 (January 1965). The latent heat of lead was obtalned fron W. M. Roheanhow and J. P. Hartnett, Handbock of Heat Transfer, McGraw-H111, New York, 1973.

For comparable propertiex of 347 stalnleas steel see V. Krelth, Prinoiples of Haat Tranofor,

Internat Ional Textbook. Scranton, Pa., 1958.

fFor comparable properties of Aluminua see J. P. Holman, Heat Tronofer, McGraw-H11l, New York, 1972.

The propertieg of alr-aluminum are for a homogenized mixture of aluwinum and alr.

The fuel is a homogenized mixture of uraniun oxide and aluminum.

For comparable properties of alr see F. Krelth, Prinoiples of Reat Tronsfor. Alr-2 has been glven

an enhanced thermal conductivity to almulate natural convection. 
Table 2.2. Material properties used in thermal analysis for ORR -oading

\begin{tabular}{|c|c|c|c|c|}
\hline Material & $\begin{array}{c}\text { Temperature } \\
\left({ }^{\circ} \mathrm{F}\right)\end{array}$ & $\begin{array}{c}\text { Thermal } \\
\text { conductivity } \\
\left(\mathrm{Btu} / \mathrm{hr} \cdot \because:{ }^{\circ} \mathrm{F}\right)\end{array}$ & $\begin{array}{l}\text { Densfty } \\
\left(1 \mathrm{~b} / \mathrm{in} .{ }^{3}\right)\end{array}$ & $\begin{array}{c}\text { Heat } \\
\text { capac1ty } \\
\left(\mathrm{Btu} / 1 \mathrm{~b}={ }^{\circ} \mathrm{F}\right)\end{array}$ \\
\hline Lead $^{a, b}$ & $\begin{array}{l}32 \\
80.3 \\
122 \\
170.3 \\
212 \\
260.3 \\
302 \\
392 \\
440.3 \\
482 \\
527 \\
572 \\
599 \\
620 \\
800 \\
980 \\
1160 \\
1340\end{array}$ & $\begin{array}{l}20.52 \\
20.30 \\
20.09 \\
i 9.51 \\
18.79\end{array}$ & 0.410 & $\begin{array}{l}0.0299 \\
0.0304 \\
0.0309 \\
0.0315 \\
0.0323 \\
0.0334 \\
0.0341 \\
0.0348 \\
0.0355\end{array}$ \\
\hline Fuel $1^{c}$ & $\begin{array}{r}32 \\
122 \\
212 \\
302 \\
572 \\
1022\end{array}$ & $\begin{array}{l}120.96 \\
123.12 \\
125.25 \\
127.44\end{array}$ & 0.0516 & $\begin{array}{l}0.086 \\
0.0926 \\
0.1217\end{array}$ \\
\hline Fuel $2^{c}$ & $\begin{array}{r}32 \\
122 \\
212 \\
302 \\
572 \\
1022\end{array}$ & $\begin{array}{l}120.96 \\
123.12 \\
125.28 \\
127.44\end{array}$ & 0.0360 & $\begin{array}{l}0.086 \\
0.0926 \\
0.1217\end{array}$ \\
\hline Fuel $3^{c}$ & $\begin{array}{r}32 \\
122 \\
212 \\
302 \\
572 \\
1022\end{array}$ & $\begin{array}{l}120.96 \\
123.12 \\
125.28 \\
127.44\end{array}$ & 0.03 & $\begin{array}{l}0.086 \\
0.0926 \\
0.1217\end{array}$ \\
\hline sST $304^{d}$ & $\begin{array}{c}32 \\
80.3 \\
170.3 \\
260.3 \\
350.3 \\
440.3 \\
620.3\end{array}$ & $\begin{array}{c}8.49 \\
8.78 \\
9.36 \\
9.82 \\
10.2 \\
10.6 \\
11.4\end{array}$ & 0.286 & 0.120 \\
\hline
\end{tabular}


Table 2.2. (coatinued)

\begin{tabular}{|c|c|c|c|c|}
\hline Material & $\begin{array}{c}\text { Temperature } \\
\left({ }^{\circ} \mathrm{P}\right)\end{array}$ & $\begin{array}{c}\text { Thersal } \\
\text { conductivity } \\
(\text { Btu/hrofte-g) }\end{array}$ & $\begin{array}{l}\text { Density } \\
\left(1 \mathrm{~b} / \mathrm{ln} .{ }^{3}\right)\end{array}$ & $\begin{array}{c}\text { Beat } \\
\text { capactty } \\
\left(\mathrm{Btu} / 1 \mathrm{~b} \cdot{ }^{\circ} \mathrm{F}\right)\end{array}$ \\
\hline sst $304^{d}$ & $\begin{array}{l}752.0 \\
800.3 \\
980.3 \\
1160.0 \\
1340 \\
1520 \\
1700 \\
1880 \\
2060 \\
2240 \\
2420 \\
2537\end{array}$ & $\begin{array}{l}12.2 \\
13.0 \\
13.8 \\
14.6 \\
15.4 \\
16.2 \\
17.0 \\
17.9 \\
18.7 \\
19.5 \\
20.0\end{array}$ & & 0.135 \\
\hline $\operatorname{A1r}{ }^{e}$ & $\begin{array}{r}32 \\
100 \\
200 \\
300 \\
4,00 \\
500 \\
600 \\
700 \\
800 \\
900 \\
1000 \\
1500\end{array}$ & $\begin{array}{l}0.0140 \\
0.0154 \\
0.0174 \\
0.0193 \\
0.0212 \\
0.0231 \\
0.0250 \\
0.0268 \\
0.0286 \\
0.0303 \\
0.0309 \\
0.0400\end{array}$ & $\begin{array}{l}4.69 \times 10^{-5} \\
4.11 \times 10^{-5} \\
3.47 \times 10^{-5} \\
3.0 \times 10^{-5} \\
2.66 \times 10^{-5} \\
2.38 \times 10^{-5} \\
2.16 \times 10^{-5} \\
1.97 \times 10^{-5} \\
1.82 \times 10^{-5} \\
1.68 \times 10^{-5} \\
1.57 \times 10^{-5} \\
1.17 \times 10^{-5}\end{array}$ & $\begin{array}{l}0.240 \\
0.240 \\
0.241 \\
0.243 \\
0.245 \\
0.247 \\
0250 \\
0.253 \\
0.256 \\
0.259 \\
0.262 \\
0.276\end{array}$ \\
\hline $\operatorname{Air} 2.0^{e}$ & $\begin{array}{r}32 \\
100 \\
200 \\
300 \\
400 \\
500 \\
600 \\
700 \\
800 \\
900 \\
1000 \\
1500\end{array}$ & $\begin{array}{l}0.02794 \\
0.03082 \\
0.03485 \\
0.03859 \\
0.04234 \\
0.04622 \\
0.04997 \\
0.05357 \\
0.05717 \\
0.06062 \\
0.06379 \\
0.08006\end{array}$ & $\begin{array}{l}4.69 \times 10^{-5} \\
4.11 \times 10^{-5} \\
3.47 \times 10^{-5} \\
3.01 \times 10^{-5} \\
2.66 \times 10^{-5} \\
2.38 \times 10^{-5} \\
2.16 \times 10^{-5} \\
1.97 \times 10^{-5} \\
1.87 \times 10^{-5} \\
1.68 \times 10^{-5} \\
1.57 \times 10^{-5} \\
1.17 \times 10^{-5}\end{array}$ & $\begin{array}{l}0.240 \\
0.240 \\
0.241 \\
0.243 \\
0.245 \\
0.247 \\
0.250 \\
0.253 \\
0.256 \\
0.259 \\
0.262 \\
0.276\end{array}$ \\
\hline $\operatorname{Alr} 5.0^{e}$ & $\begin{array}{r}32 \\
100 \\
200 \\
300\end{array}$ & $\begin{array}{l}0.06984 \\
0.07704 \\
0.08712 \\
0.09648\end{array}$ & $\begin{array}{l}4.69 \times 10^{-5} \\
4.11 \times 10^{-5} \\
3.47 \times 10^{-5} \\
3.01 \times 10^{-5}\end{array}$ & $\begin{array}{l}0.240 \\
0.240 \\
0.241 \\
0.243\end{array}$ \\
\hline
\end{tabular}


Table 2.2. (continued)

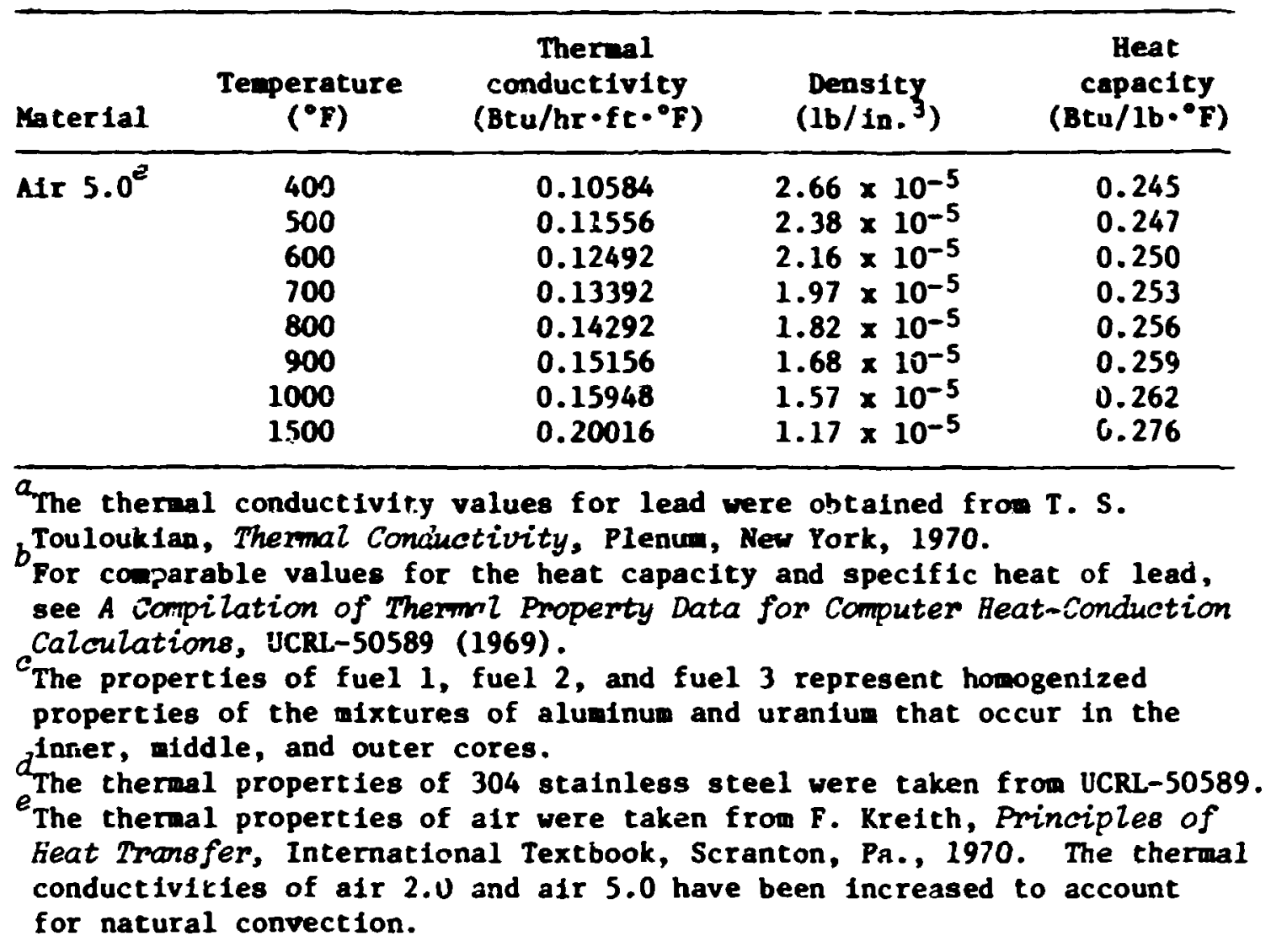


There are many expressions for ke sepending mainly on the actual geowetry. However, a rather simple expression derived from Rraussold's work 27 w1l produce sufficient accuracy for most cask calculations. The expression is

$$
k e / k=A(R a)^{b}
$$

The coefficients $A$ and $b$ depend on the range of the Rayleigh number as follows:

$\begin{array}{ccc}\underline{\mathrm{Ra}} & \underline{\mathrm{A}} & \underline{\mathrm{b}} \\ 10^{3}-10^{4} & 0.251 & 0.2 \\ 10^{4}-10^{6} & 0.100 & 0.3 \\ 10^{6}-10^{8} & 0.398 & 0.2\end{array}$

This type of convection moveling was used in the analysis of the cask carrying ORR elements. The materials, AIr-2.0 and Alr-5.0, are used to model the effects of natural convection by increasing the effective conductivity of the air.

\subsection{Thermal Evaluation for Normal Conditions of Transport}

The evaluations for the normal conditions of transport are outlined below.

\subsubsection{Thermal model}

The computational model representing the HPIR cask and Its intended contents is illustrated in Figs. 2.1 and 2.2. Figure 2.1 is a twodimensional model of the cask loaded with the HFIR core, and Fig. 2.2 represents it loaded with 17 ORR-type elements. In both cases, the fuel Is modeled as a homogeneous material (fuel 1 , fuel 2 , and fuel 3 ) with conductivity, density, and heat generation adfusted. The three fuels used In the ORR loading, fuel 1 , fuel 2 , and fuel 3 , represent homogenized materials in the inner core, middle core, and outer core, respectively. 


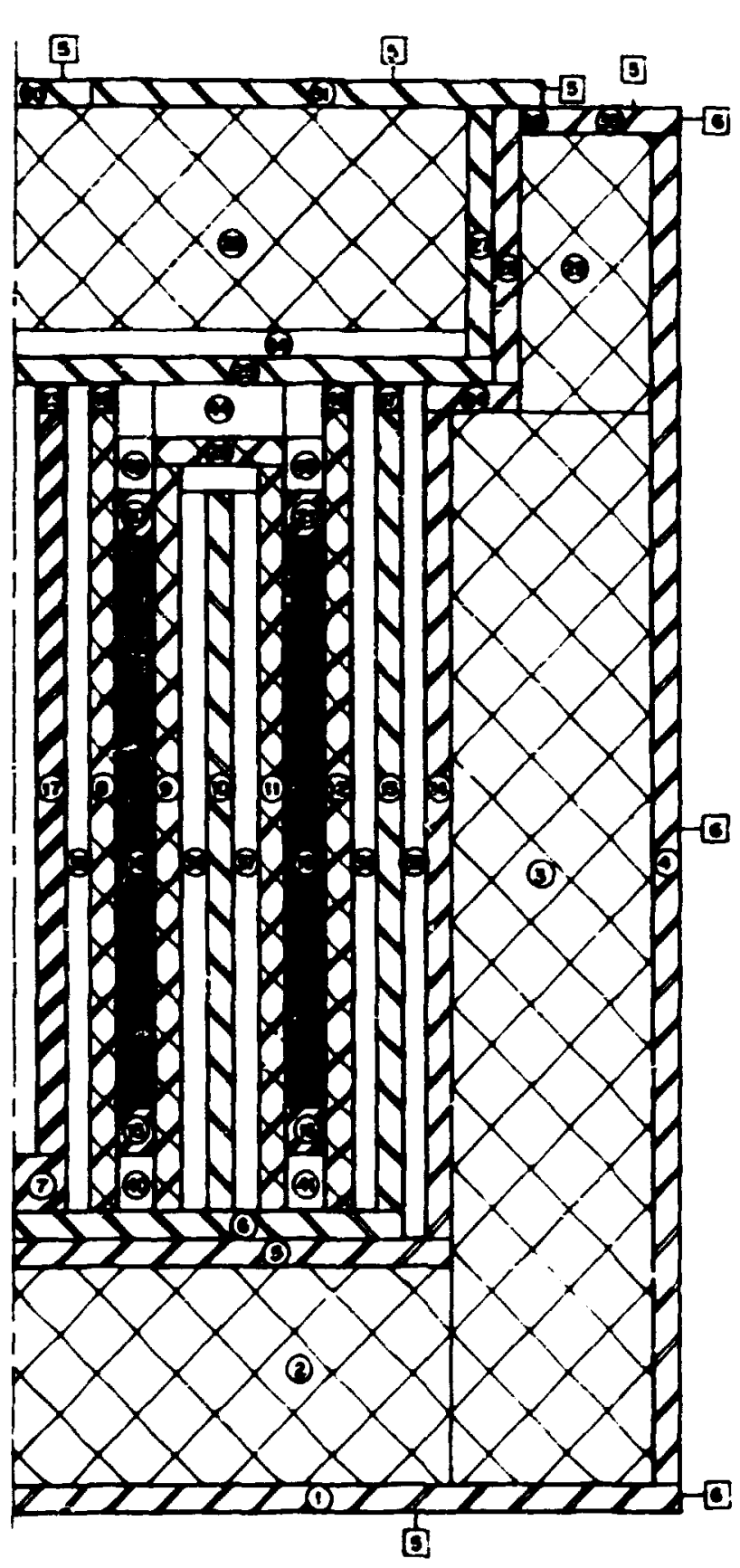

OnIL DEG r4-6494

(2) $e^{E-51.000}$ $8-3000$ $\theta_{0}-30000$ $\theta-33.000$ S- 31.000 8 - -10 (3)-4.3rs Q- 47.750 $\theta_{2}-46.075$ Q Q -4.375 (2) 39.375 Q 2 39.375 Q 33.375 (10) - 3isrs Q- 2o.srs ()- 27.3rs (1) 25.375 (1) 23.3rs (3) - 21.375 (1)- n.3rs (2) $17-17000$ O 15.900 (i)- 12.000 (3) $-\infty .000$ (1) 1000 () -1500 (3) -1000 (2)

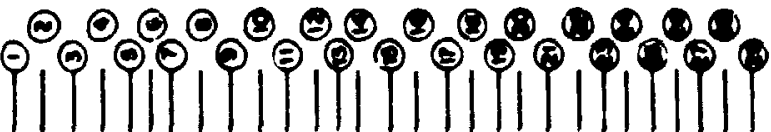
$\frac{4 \text { ters? }}{201}$ 08 a $\square$ man

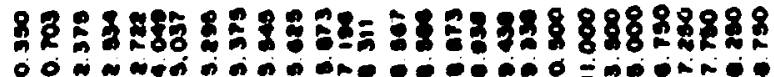

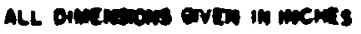

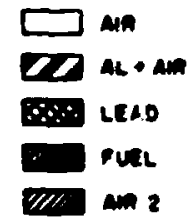

I1g. 2.1. Heat transfer model cask loaded wth HFIR core. 


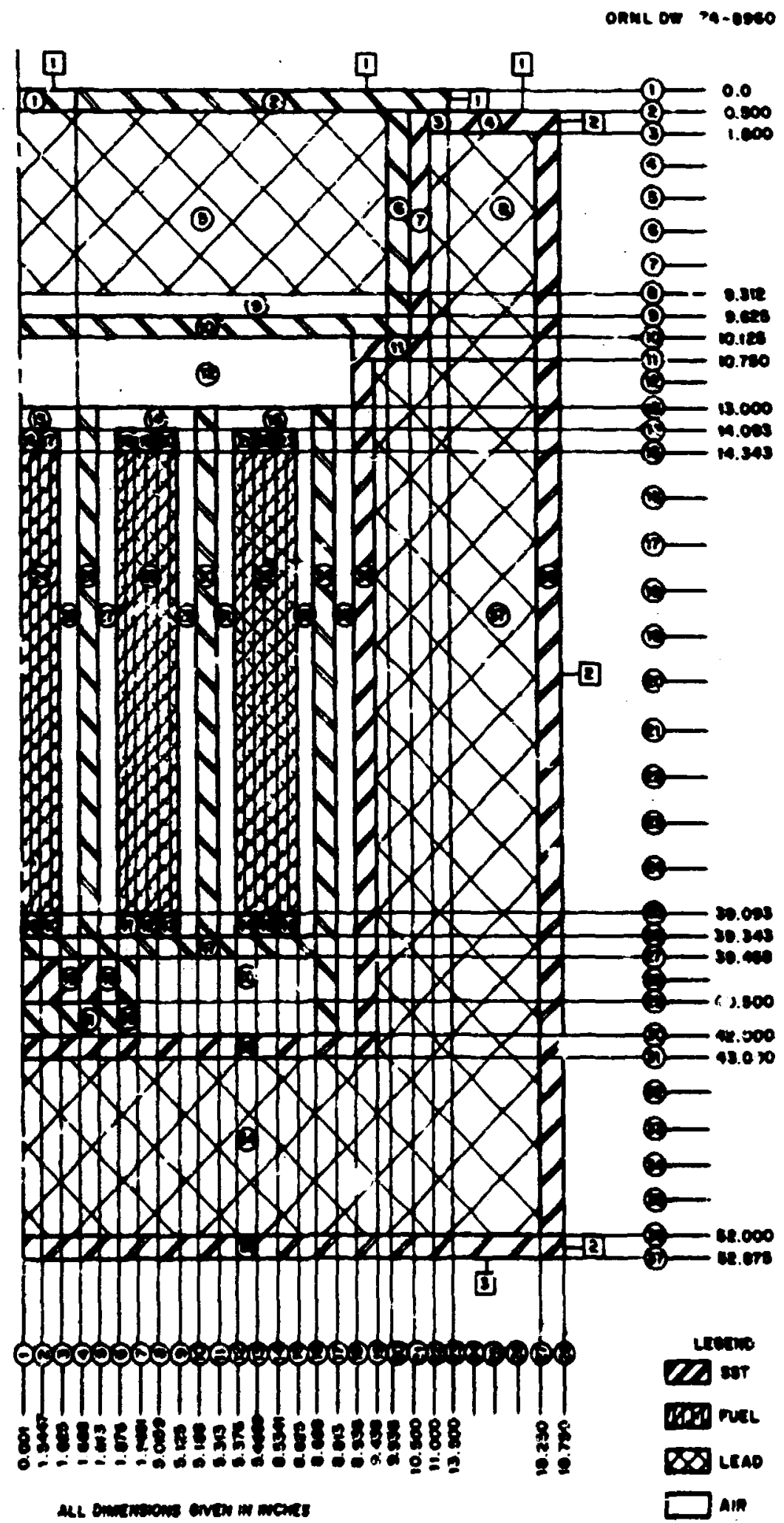

F18. 2.2. Heat transfer model cask loaded with 17 ORR elements. 
The efficiency of the fins has been previously calculated, ${ }^{2}$ and the coefficient for the outer surface was raised to compensate for the exclusion of the fins from the model.

In calculating the steady-state temperature for the $130^{\circ} \mathrm{F}$ environment In direct sunlight, it was assumed that a solar heat flux of 144 $B t u / h r \cdot f t^{2}$ was incident upon the cask. The fraction of the inctdent solar flux that is absorbed by the cask is equal to the absorptivity of the cask, assumed conservatively to be 1.0. The ends are not insulated.

\subsubsection{Maximun temperatures}

Maxinum temperatures are presented in Tables 2.3 and 2.4 for the environents of $130^{\circ} \mathrm{F}$ in direct sunlight and $100^{\circ} \mathrm{F}$ in the shade. For the $100^{\circ} \mathrm{F}$-in-the-shade environment, the maximum accessible surface temperature was $151^{\circ} \mathrm{F}$ when $10 a d e d$ with the HFIR cos and $178^{\circ} \mathrm{F}$ when loaded with 17 ORRtype elements at an elevation of $16-1 / 2$ in. nn the cylindrical portion of the cask. Since this is less than $180^{\circ} \mathrm{F}$, the container complies wtth the lattez environmental requirement. Calculated temperatures are well within the operating ranges for all naterials, and no cask structural materials exhibit a significant 108 of mechanical properties at these temperatures. The prinaly seal (silicone rubber gasket) is satisfactory for the alculated temperatures. The fuel temperatures will not cause fallure of cladding.

Actual temperature measurements were made on the cask in 1967.32 The cask was loaded with an HFIR elemant having a total decay heat output of $3.2 \mathrm{~kW}$. After $19 \mathrm{hr}$, the maximum inner temperature reached $198^{\circ} \mathrm{F}$, while the maximum accessible ourface temperature reached $124^{\circ} \mathrm{F}$. This reflects the cunservation used in the calculations.

\subsubsection{Minimum temperaturize}

Reduced or zero heat loads would lower temperatures throughout the container. This situation would not affect the safe operation of the container nor the margin of safety (see Sect. 1.4 .2 for discusston of the low temperature effects). 
Table 2.3. Cask temperatures with BFIR core

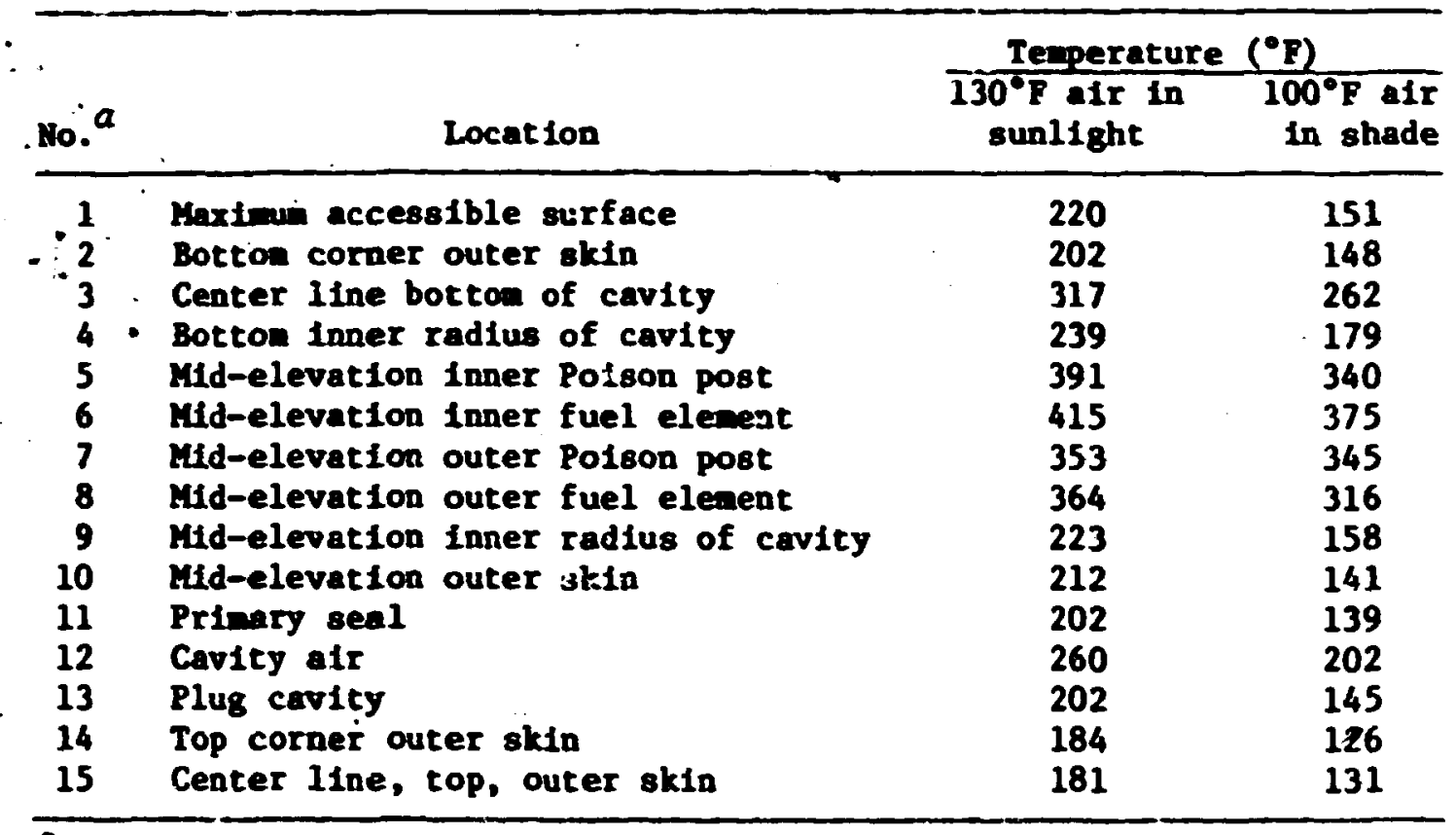

$a_{\text {See }, F 18.2 .3}$ for 'ocations.

Table 2.4. Cask temperatures with 17 ORR elements

\begin{tabular}{|c|c|c|c|}
\hline Ho. ${ }^{a}$ & Location & $\begin{array}{l}\text { Temperatur } \\
130^{\circ} \frac{\mathrm{F} \text { air In }}{\text { sunlight }}\end{array}$ & $\begin{array}{l}\left({ }^{\circ} \mathrm{F}\right) \\
100^{\circ} \mathrm{F} \text { alr } \\
\text { in shade }\end{array}$ \\
\hline $\begin{array}{r}1 \\
2 \\
3 \\
4 \\
5 \\
6 \\
7 \\
8 \\
9 \\
10 \\
11 \\
12 \\
13\end{array}$ & $\begin{array}{l}\text { Maximm accessible surface. } \\
\text { Mid-elevation center elewent } \\
\text { Mid-elevation 2d-row eletrent } \\
\text { Mid-elevation 3d-row element } \\
\text { Mid-elevation Inner cavity wall } \\
\text { Mid-elevation outer shell (eurface) } \\
\text { Cask gastet } \\
\text { Top cask surface } \\
\text { Mean plug lead } \\
\text { Body lead at mid-elevation } \\
\text { Mean air in plug cavity } \\
\text { Mean air in shield cavity } \\
\text { Mean air in cask cavity }\end{array}$ & $\begin{array}{l}221 \\
730 \\
715 \\
617 \\
240 \\
220 \\
228 \\
222 \\
223 \\
228 \\
225 \\
228 \\
300\end{array}$ & $\begin{array}{l}178 \\
703 \\
690 \\
590 \\
184 \\
165 \\
170 \\
158 \\
160 \\
175 \\
193 \\
175 \\
263\end{array}$ \\
\hline
\end{tabular}

$a_{\text {See FIg. } 2.4 \text { for locations. }}$ 
ORNL CWG 74-96\%9

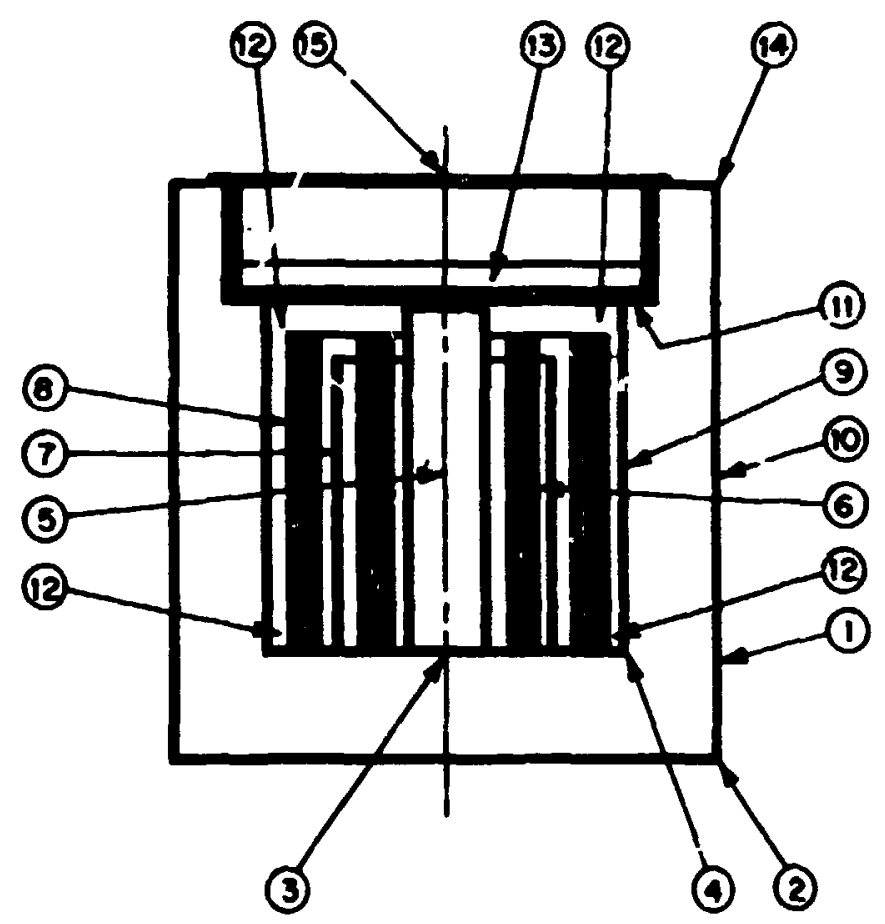

F1g. 2.3. Temperature location diagram (HFIR core).

ORNL OWE 75-12974

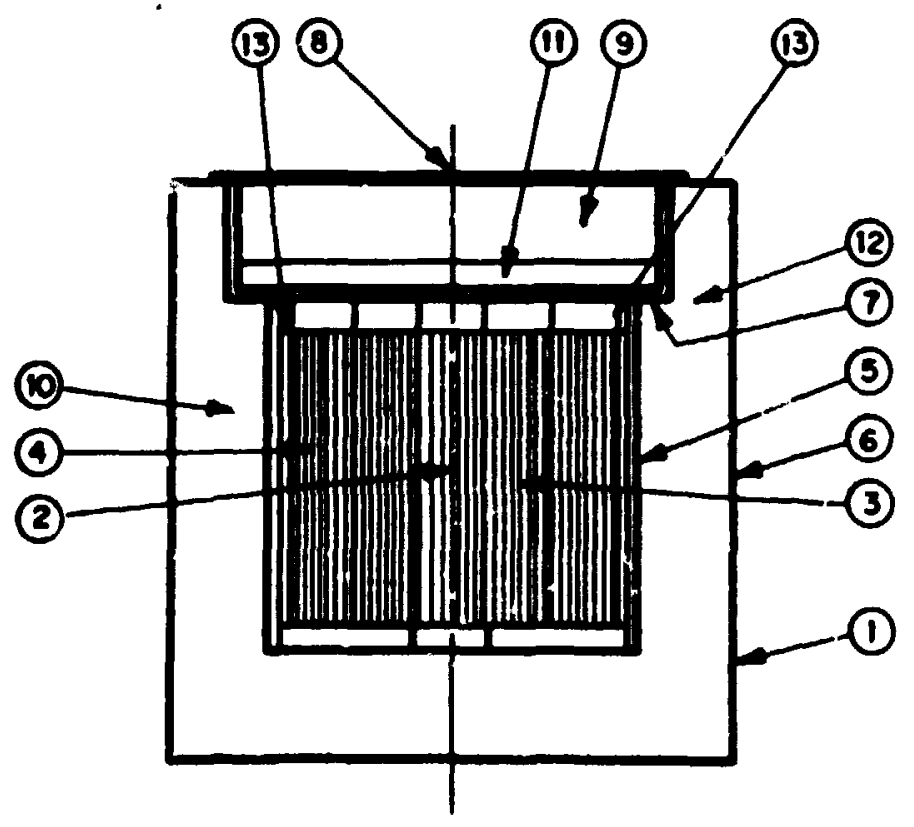

F1g. 2.4. Temperature location diagram (ORR loading). 


\subsubsection{Yaximun internal pressure}

There would be $c$. rise in pressure in the cask cavity and shielding cavities due to the increase in temperature. The resulting pressures are calculated from the therwodynatc law assuning constant voluse, a sealing temperature $T_{1}$ of $70^{\circ} \mathrm{F}\left(530^{\circ} \mathrm{R}\right)$, an atwospher ic sealing pressure $P_{1}$ of 14.7 pela, and the relationship

$$
P_{2}=P_{1} T_{2} / T_{2} \text { : }
$$

The pressure in the cavity would be

$$
P_{2}=14.7(760) / 530=21.1 \mathrm{psia}=6.4 \mathrm{ps} 18 .
$$

The pressure in the lead cavity would be

$$
P_{2}=14.7(688) / 530=19.1 \mathrm{psia}=4.4 \mathrm{ps} 18 .
$$

The pressure in the plug cavity would be

$$
P_{2}=14.7(685) / 530=19.0 \mathrm{psia}=4.3 \mathrm{ps} 1 \mathrm{~g} .
$$

\subsection{Hypothetical Thermal Accident Evaluation}

The danage from the free-drop and puncture portions of the hypothetical accident would not adversely affect the performance of the container in the bypothetical thermal accident; hence, the undameged configuration was sesumeti.

\subsubsection{Thereal nodei}

The analyilcal nodel described in Sect 2.3 .1 was ved for the accident evaluatlon. 


\subsubsection{Thermal accident analysis}

The HEATING-3 17 computer program was used to determine the temperature dis:ribution and the quantity and location of the lead that would alt as a result of the prescribed 30-imin thermal exposure. The material constants from Table 2.1 were used as input. The steady-state temperature distribution couputer for normal conditions of transport for the HFIR core loading (Sects. 2.4.2 and 2.4.3) was used for initial temperatures.

\subsubsection{Analysis resulte}

Temperatures with respect to time for the locations of concern for the spectfled exposure and subsequent ccol-douns are presented in Figs. 2.3, 2.5, and 2.6. The quantity and locations of the lead that would melt are shown in $F ! 8 \cdot 1.42$.

\subsubsection{Internai pressures.}

The pressure in the cask cavity may be calculated from the perfect gas laws. W th reference to $\mathrm{Fig}, 2.3$ and 2.5. the maximum temperature of the cask cavity air is reachad at time equal to $60 \mathrm{~min}$ or $30 \mathrm{~min}$ after the fire is extinguished (see curve 12, Fig. 2.5). The temperature reaches $460^{\circ} \mathrm{F}\left(920^{\circ} \mathrm{R}\right)$. Assume constant volume and that the cavity was sealed at a temperature I of $70^{\circ}\left(530^{\circ} \mathrm{R}\right)$ and at an atmospheric pressure of 14.7 psia. The maximum cavity pressure $P_{2}$ is

$$
P_{2}=P_{1} T_{2} / T_{1}=14.7(920) / 530-25.5 \mathrm{ps} 1 \mathrm{a}-10.8 \mathrm{ps} 1 \mathrm{~g},
$$

which 18 less than the design pressure adjusted for temperature per the Code. 25

\section{CONTAIMMENT}

\subsection{Contsinment Boundaries}

Primary containmen: 18 forwed by the cask cavity, plug, and seal as indicated in Fig. 1.41. An additional line of containment is formad by 


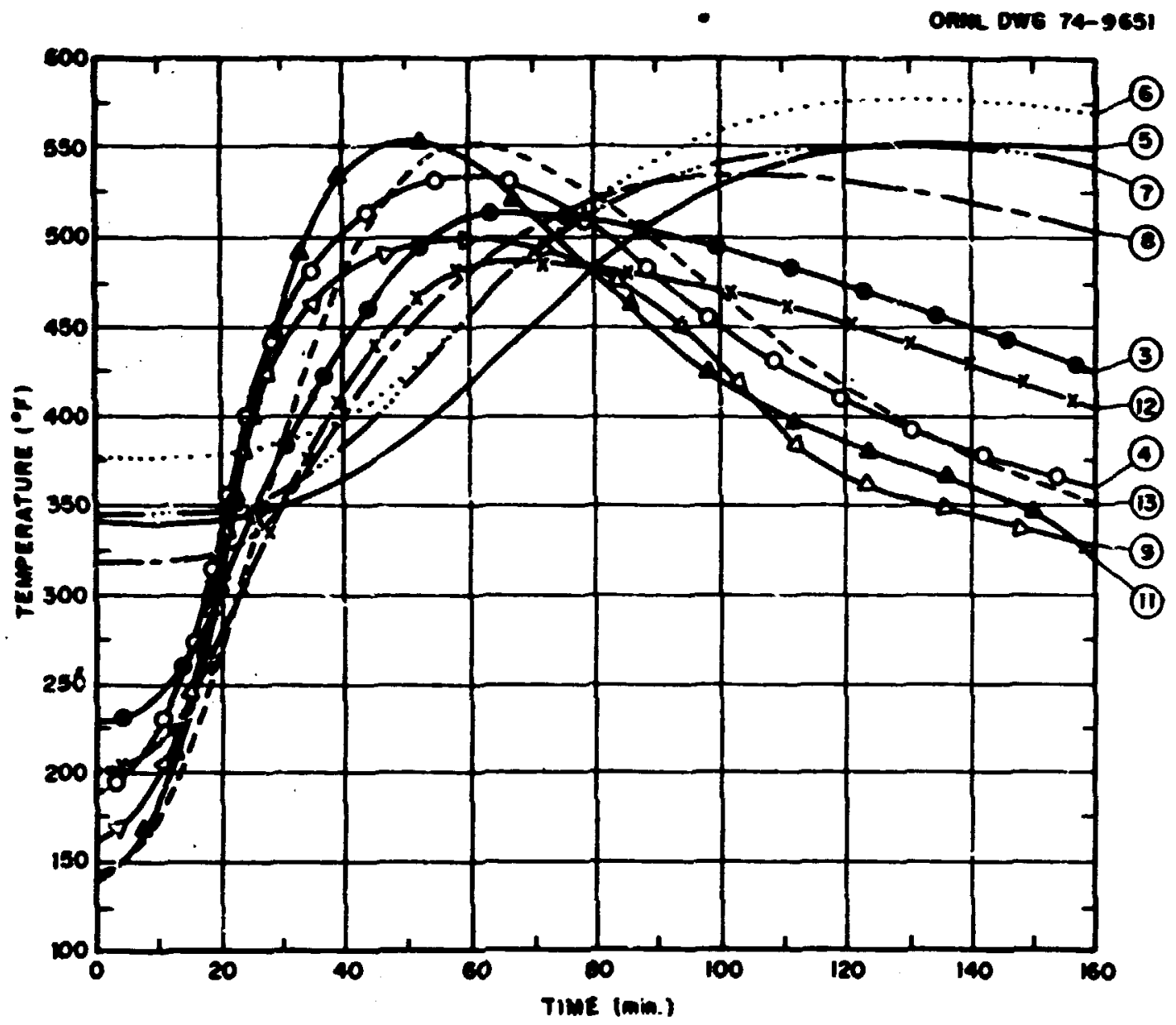

Fig. 2.5. Temperature of cask loaded with HFIR during fire simulation. 
ORNL OWG 74-9650

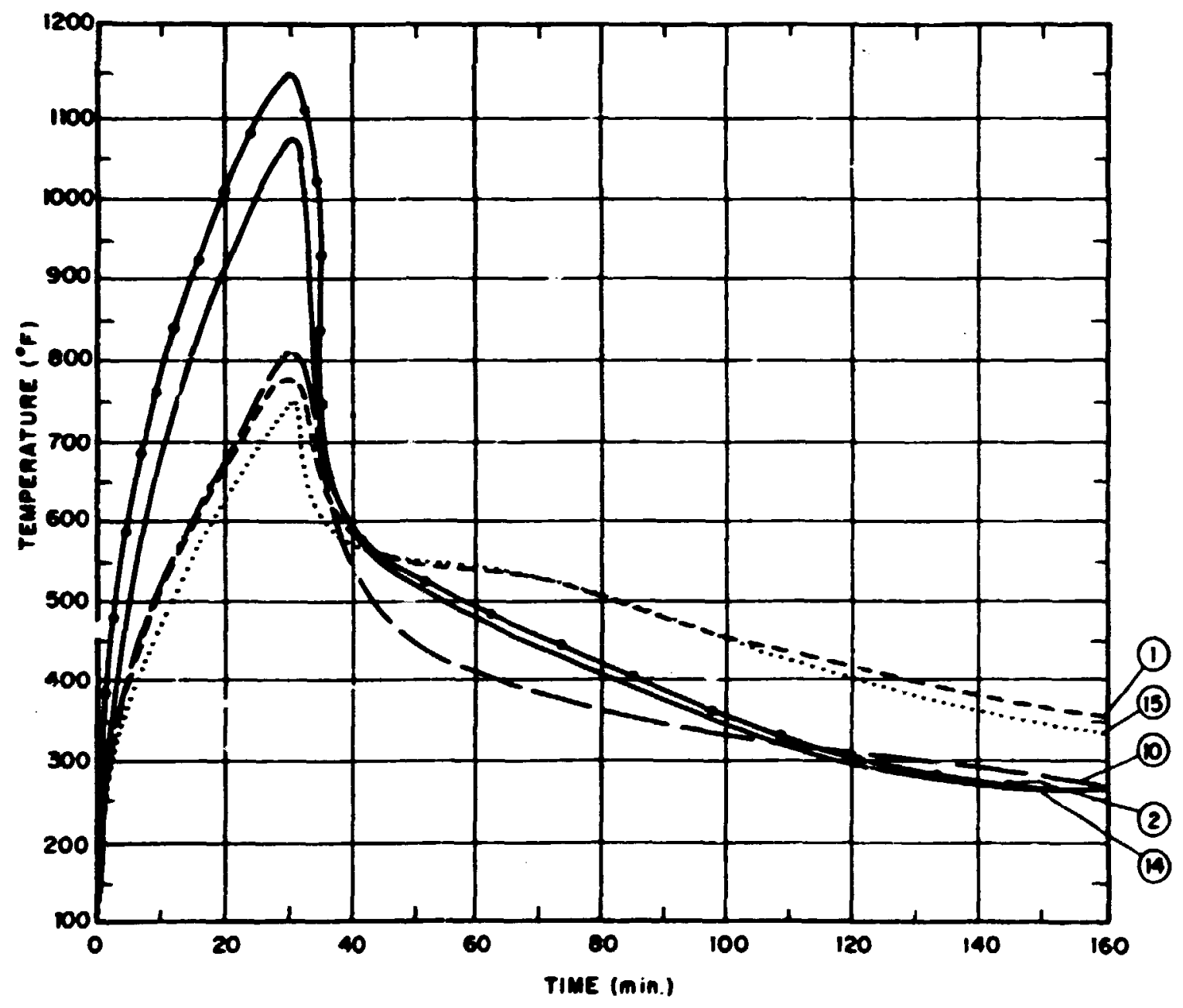

F18. 2.6. Temperature of cask loaded with HFIR core. 
the fuel elements' cladding. Primary containment is routinely pressure tested (Appendir G) after the cask is loaded.

\subsection{Requifrenents for Nornal Transport}

The contaiment vessel is designed to maintain contaiment during notnal conditions of transport. The evaluetions of Sects. 1.4, 1.6, and 2 demonstrate the adequacy of the design. The cask has been in use since 1966 without 1088 of contalnment. The routine pressure tests periodically dewonstrate adequacy of the containent vessel.

\subsection{Containment Requirements. During the Hypothetical Accident}

The cask will maintain contaiment during and after the specified hypothetical accident. The evaluations of Sect. 1.7 demonstrate that there will be no stresses in the containment vessel exceeding the static yield 8tres8. The thermal evaluation in Sect. 2 demonstrates that the temperatures in the vessel are within the operating $11 \mathrm{mits}$ of the materials. The 8111 cone rubber gasket reaches a maximum temperature of $550^{\circ} \mathrm{F}$. It has been reported 18 (Pig. 3.1) that the useful service life of a silicone rubber gasket at $550^{\circ} \mathrm{F} 18$ about $5 \mathrm{hr}$. With reference to F1g. 2.5 , it can be - seen that time above $500^{\circ} \mathrm{F}$ is only about $40 \mathrm{~min}$. The useful service life of a silicone rubber gasket at $500^{\circ} \mathrm{F}$ is approximately $11 \mathrm{hr}$ (F1g. 3.1). Sinilarly, the time above $400^{\circ} \mathrm{F}$ is $1 \mathrm{hr} 25 \mathrm{~min}$; the useful service life at $400^{\circ} \mathrm{F}$ is in excess of $1000 \mathrm{hr}$. It is concluded, therefore, that the seal w11 not fall as a result of the thermal exposure; thus, if the cask is innersed, the in-leakage of water would not occur.

\section{SHIELDING}

Blological shielding from gammo radiation is effected by a minimum thlckness of $8.75 \mathrm{in}$. of lead and 1 in. of stainless steel cladding.

\subsection{Normal Conditions}

A detalled shielding analysis was prepared and presented in the or1ginsl cask design report. ${ }^{2}$ Th1s analysis was based on an operating 
ONWL DNe No. 11-13030

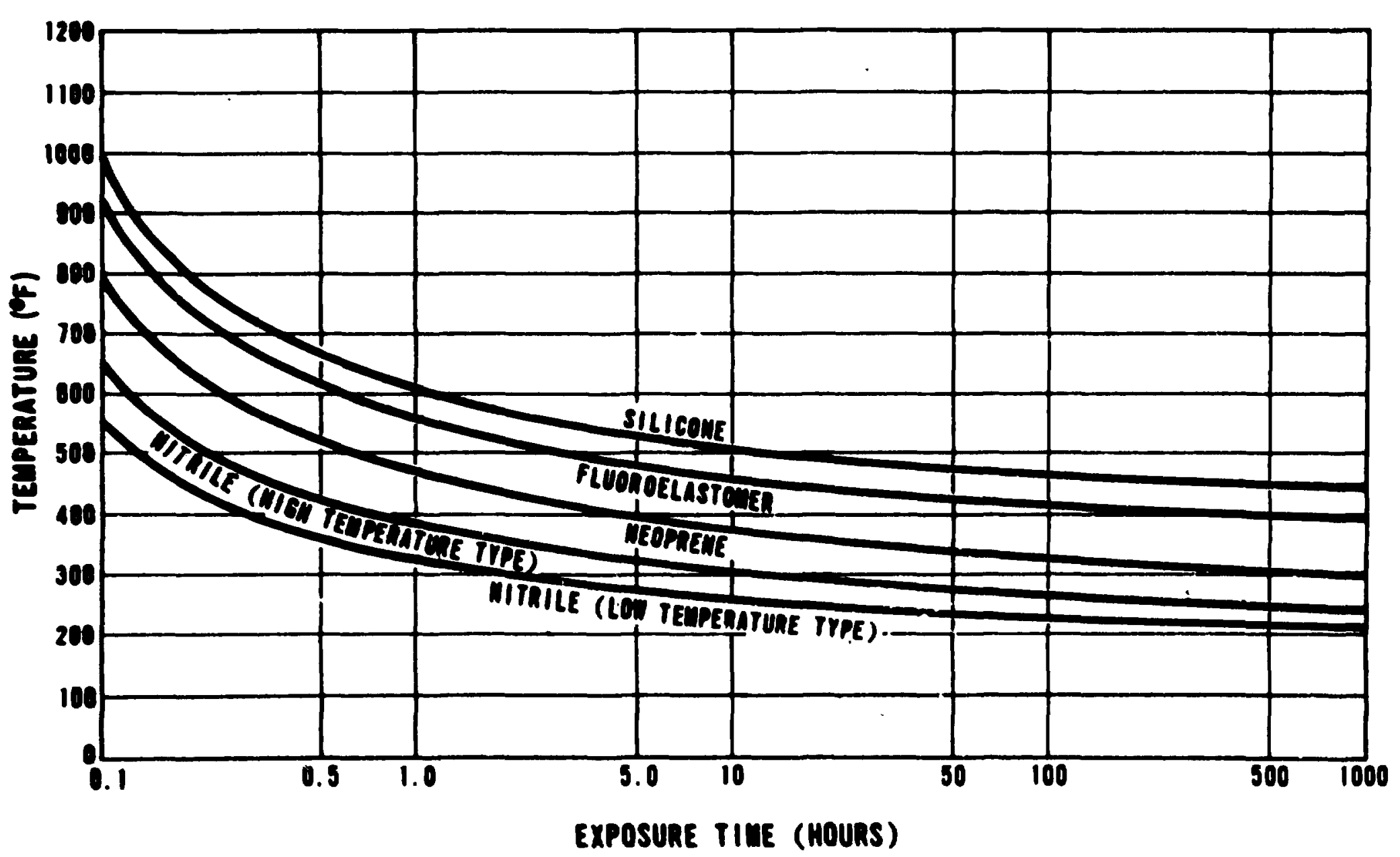

F1g. 3.1. Gasket service temperatures (ref. 19). 
cycle of 15-day irradiation of the fuei at $100 \mathrm{Mi}(t)$ follored by 270-day cooling. Conservation In the analysis was sufficient to allow shipment of elements from current operating cycle of 23-day irradiation at $100 \mathrm{MW}(t)$ followed by a 240-day cooling period. A routine portion of preshipment Inspection (Appendix G) is deternining the dose rate at the surface of the cask and 3 ft from the surface as required by the regulations. 4 This scan is perforwed by the ORWL Health Physics Division prior to the cask's leaving the confines of ORML. A written report of this inspection is prepared for every shipwent. A copy of a typical report is presented in Appendix G. This report-demonstrates that the HPIR cask, when loaded with the spent HFIR element that hus experienced the current operating cycle, complies with the requirements of the regulations with regard to dose rate under zormal conditions. The dose rate at the cask surface was measured at $20 \mathrm{millirems} / \mathrm{hr}$, as conpared with the allowable rate ${ }^{5}$ of $200 \mathrm{millirems}$ hr. At a distance of $3 \mathrm{ft}$ from the cask surface, the measured rate was $2.3 \mathrm{mllll}$ rems/hr as compared with an allowable rate 5 of $10 \mathrm{mill}$ rems/hr. It is therefore evident that the cask complies with the regulations from the standpoint of shielding for normal conditions.

\subsection{Accidenc Conditions}

The redistribution of shielding resulting from the $30-\mathrm{ft}$ and $40-1 \mathrm{n}$. free-falls is small (Sect 1.7). If subje, ced to the 30-min thermal exposure as specified, \& portion of the shielding would meit (Fig. 1.42). It 18 not anticlpated that the shell would rupture and that shielding would be lost. Some redistribution of the shlelding could result when the lead solidified. This redistribution covld result in a reduction of shlelding, particularly in the plug where a vold volume was provided in the lower part of the plug. A prediction of the amount and location of the shlelding redistribution cannot be made with confidence; thus, a calculation was made assuming 1088 of the melted shlelding. J. R. Knight of the Computer Sclences Division of Unton Carb1de Corporation-Nuclear Division (UCC-ND) performed the calculation. A copy of his report is presented in Appendix H. In summary, this evaluation found that the dose rate at the surfaces and at $3 \mathrm{ft}$ would increase by a factor of 22 above 
the nonaccident dose rates. Based on the allowable limits for shipments of 200 millirens at the surface and $10 \mathrm{mllitems} / \mathrm{hr}$ at $3 \mathrm{ft}$, che accifent condition rate would be 220 millirems/hr at $3 \mathrm{ft}$ - much lower than the $1000 \mathrm{millirens} / \mathrm{hr}$ allowable by the regulations.

\section{CRITICALITY}

The ORNL criticality comittee has evaluated the container and its contents as described in Sect. 0.2 and the as-bullt drawings in Afpendix $A$. These evaluations, presented in Appendix I, demonstrate compliance with the regulations. Critical experiments reported by Johnson ${ }^{28}$ and by Rafferty and Thomas 29 for the HFIR elements and by Johnson and Reedy 30 for the ORR-type elements form the bases for combltee approval. The PRNC elements are of similar geometry to ORR elements and contain less ${ }^{235} \mathrm{U}$ at lower enrichments; hence, their shipment complies with the regulations by comparison with the ORR elements. Accelerations of the magnitude computed for the accident conditions will not alter the element geovetry. Therefore, the contents will remain subcritical after the accident.

\section{QUALITY ASSURANCE}

The majority of the fabrication work on the cask was performed prior to the requirements for a formal quality assurance program. The fabrication was performed at ORNL and Y-12 shops in accordance with normal shop procedures. Material was specified on the original drawings (Appendix A) to conform to American Society for Testing Material (ASTM) specifications. Material was withdrawn from UCC-ND stores stock or purchased in accordance with the applicable ASTM specifications. Stores stock was purchased in accordance with the appropriate specifications. Material certifications were procured for all material purchased from vendors specifically for the cask. However, these documents were not retained. Helding was specifled to conform to formal ORNL welding and inspection proceduraa (Appendix A). The cask was inspected for total fabrication by $0^{-}$ inspection personnel to ensure compliance with the welding requirem... Dimensional inspections were also made at appropriate intervals during fabrication and on the completed cask. The acceptance tests specified 
by the drawings were performed. The fabrication records for the cask are on permarent file at Oak Ridge National Laboratory.

The nodifications to the cask are to be performed in accordance with the drawings, notes, and the ORNL quality assurance procedures applicable to quality level III fabrication. The welds will be wade in accordance with the specified WPS specifications and inspected as specified on the drawings. The waterial used in wodifications will be withdrawn from ORNL stores stock, which was purchased in accordance with the drawing specifications. Dimensional Inspections of the modifled cask are to be performed. Quality assurance program plans for the modifications are in Appendix J.

\subsection{Operating Procedures and Routine Inspection}

The ORNL. Operations Division has established operating and routine Inspection procedures and standard checklists to ensure that all shipments are safe and comply with Federal regulations $3,4,5$ and with all ORNL procedures and regulations. Coples of the procedures and checklists are presented In Appendix G.

\subsection{Periodic Maintenance and Inspection}

Inspections are performed prior to each shtpment as outlined above. Maintenance is required when inspections indicate damage. There are no cime-degradable materials (except the gaskets) used in the construction of the containers. The gaskets are replaced routinely (Appendix G). 


\section{REFERENCES}

1. Atomic Energy Comission Proposed Regulation, "Protection Against Radiation in the Shipient of Irradiated Fuel Elements," 10 CFR 72, Federal Register, Document 61, 9151, Sept. 22, 1961.

2. J. H. Evans et al., Analysis of HFIR Irradiated Fuel Element Shipping Cask, ORNL/TM-959 (January 1965).

3. Code of Federal Regulati,ns, Title 10, Part 71, "Transport of Licensed Materials."

4. United States Atomic Energy Commission AEC Manual, Volume 0000, General Administration, Part 0500, Health and Safety, Chapter 0529, "Safety Standards for the Packaging of Radioactive or Fissile Materials," Aug. 22, 1966.

5. Code of Federal Regulations, Title 49, Part 173, "Transportation."

6. G. M. Adamson, Jr., and R. H. Knight, Specifications for High Flux Isotope Reactor Fuel Element, HFIR FE-2 Metals and Ceramics Division, ORNL (October 1966).

7. Mechanical and Physical Properties of Austenitic Chromiun Nickel Stainless Steel at Ambient Temperature, International Nickel Company, 1963.

8. "Machine Design," The Ferrous Metals Book, Penton, Cleveland, Oh1o, 1961.

9. J. H. Evans, "Experimental Study of the Stress-Strain Properties of Lead Under Specified Impact Conditions," Structural Analysis of Shipping Casks, vol. 8, ORNL/ TM-1312 (August 1970).

10. L. B. Shappert et al., Cask Designer's Guide, ORNL-NSIC-68 (February 197C).

11. Donald S. Clark, "The Influence of Impact Velocity on the Tensile Characteristics of Some Air Craft Metals and Alloys," NACA TN-868, Washington, D.C., October 1942.

12. J. H. Evans, "Experimental Siudy of the Stress-Strain Properties of Cask Materials Under Specified Impact Conditions," Proceedings of the Fourth International Symposizm on Packaging and Transportation of Radioactive Materials, CONF-470901-P1 (September 1974).

13. E. Orbert and F. 0. Jones, Machinery's Handbook, 17th ed., Industrial Press, New York, 1964 . 
14. R. T. Berger, "Eccentrically Lorded Jolnts, Streamilned Solutions for Finding Haximum Bolt Loeds," Machine Design, Penton, Cleveland, Ohio. August 1967.

15. J. H. Faupel, Bngineering Design, A Synthesis of Strese Analysis and Nateriale Bngineering, !' ley, New York, 1904.

16. S. Timoshenko, Strength of Vaterials, Part II, Advonced Theory and Problems, 3d ed., Van Nostrand, irinceton, New Jersey, 1956.

17. W. D. Turner and H. Siman-Tov, BFATING-3, an IBN 360 Heat Conduction Progran, ORN/TH-3208 (February 1971).

18. Parker Seal Comany, Seal Compound Manual, Catalog C5702, Cleveland, Ohio, Apr11 1967.

19. P. C. Davis, "Energy Absorption Capabilities of Plastically Deformed Struts Under Specifled Iupact Condftions," Structural Analysis of

- Shipping Cask8, vol. 9, ORNL/MH-1312 (Pebruary 1971).

20. J. H. Evans, "A Fortran Progran for Estination of the Response of Gylindrical Lead-Shle? of Shipping Casks, vol. 13, ORNL/TM-1312 (June 1974).

21. J. H. Evans, "An Experimental and Antylytical Evaluation of the Tubes In Pipe Energy Absorbers," Structural Analysis of Shipping Casks, vol. 10, ORNL/TH-1312.

22. J. H. Evans, "Ispact Testing of Chemical Lead, Cask Models and an Energy Absorbing Device," Proceedings of the Thind Intermational Symposim on Packaging and Transportation of Radimetrive Naterials, vol 2., CONF-710801, Richland, Wash1ngton, August 1971.

23. H. A. Nelms, "Effects of Jacket Physical Properties and Curvature on Puncture Resiocance," Sthuctural Aralysis of Shipping Casks, vol. 3, ORN/TH-1312 (June 1968).

24. A. R. Spaller, "Resistance to Puncture," Structural Analysis of Shipping Casks, vol. 2, ORNL/Mi-1312 (September 1966).

25. ANSE boiler and Pressure Code, Sict. VIII, New York, 1974.

26. T. P. Hdanrick, unpublished report (see Appendix D).

27. R. R. G. Eckert and R. M. Drake, Jr., Analysis of Heat and Hase Transfer, McGraw-H111, New York, 1972.

28. 8. B. Johnson, Critical Lattiose of Bigh Plux Isotope Reaotor Suel LZemento, ORNL/Th-1808 (March 1967). 
29. S. J. Rafferty and J. T. Thonas, Experimental netermination of Safe Hanciling Procedures for High Flux Isotope Reactor Fuel Elements Outside the Reactor, ORNL/IN-1488 (July 1966).

30. E. B. Johnson and R. R. Reedy, Critical Experirents With Spent Fuel Elements, ORNL/Tt-1207 (July 1965).

31. W. Griffel, Rigid Erame Formulae, Pruduct Engineering, Apr. 13, 1964.

32. R. V. McCord and B. L. Corbett, Bigh Flux Iootope Reactor Quarterly Report, January, February and inarch of 1967, ORM/TM-1895 (June 1967). 
Appendix A

AS-BUILI DRAWINGS 


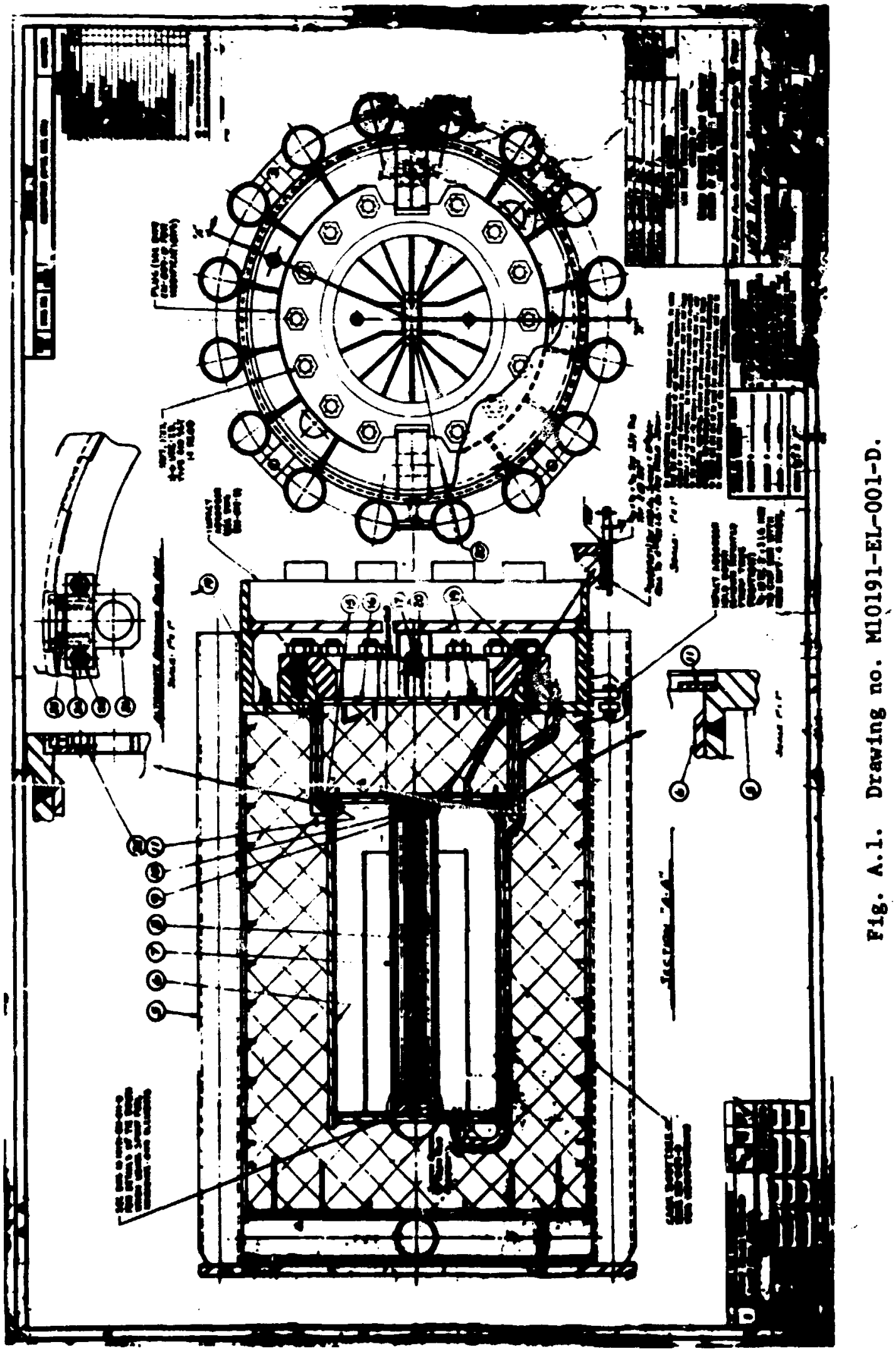




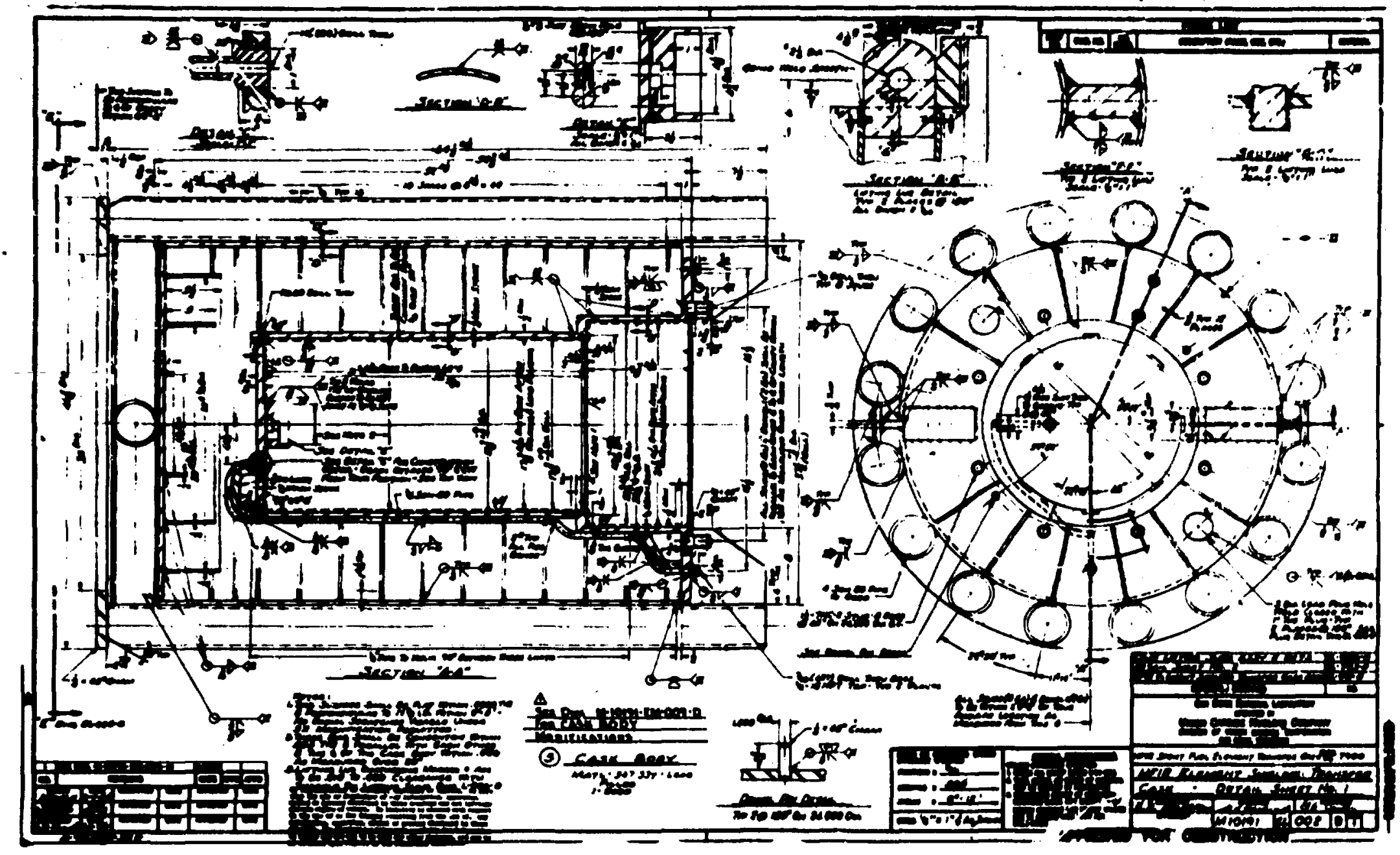

F18. A.2. Drawing no. M10191-EL-002-D. 


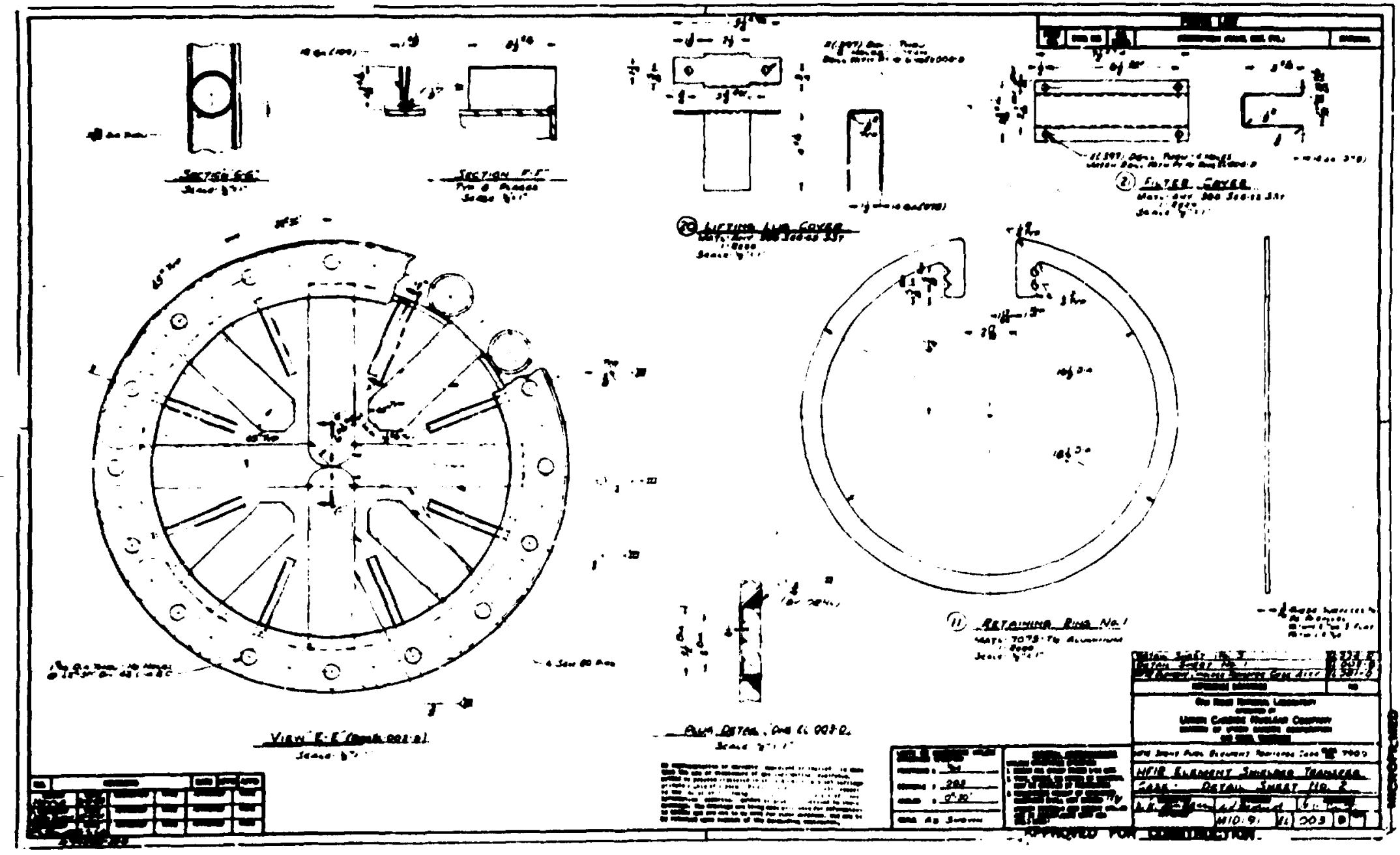

Fig. A.3. Drawing no. M10191-EL-003-D. 


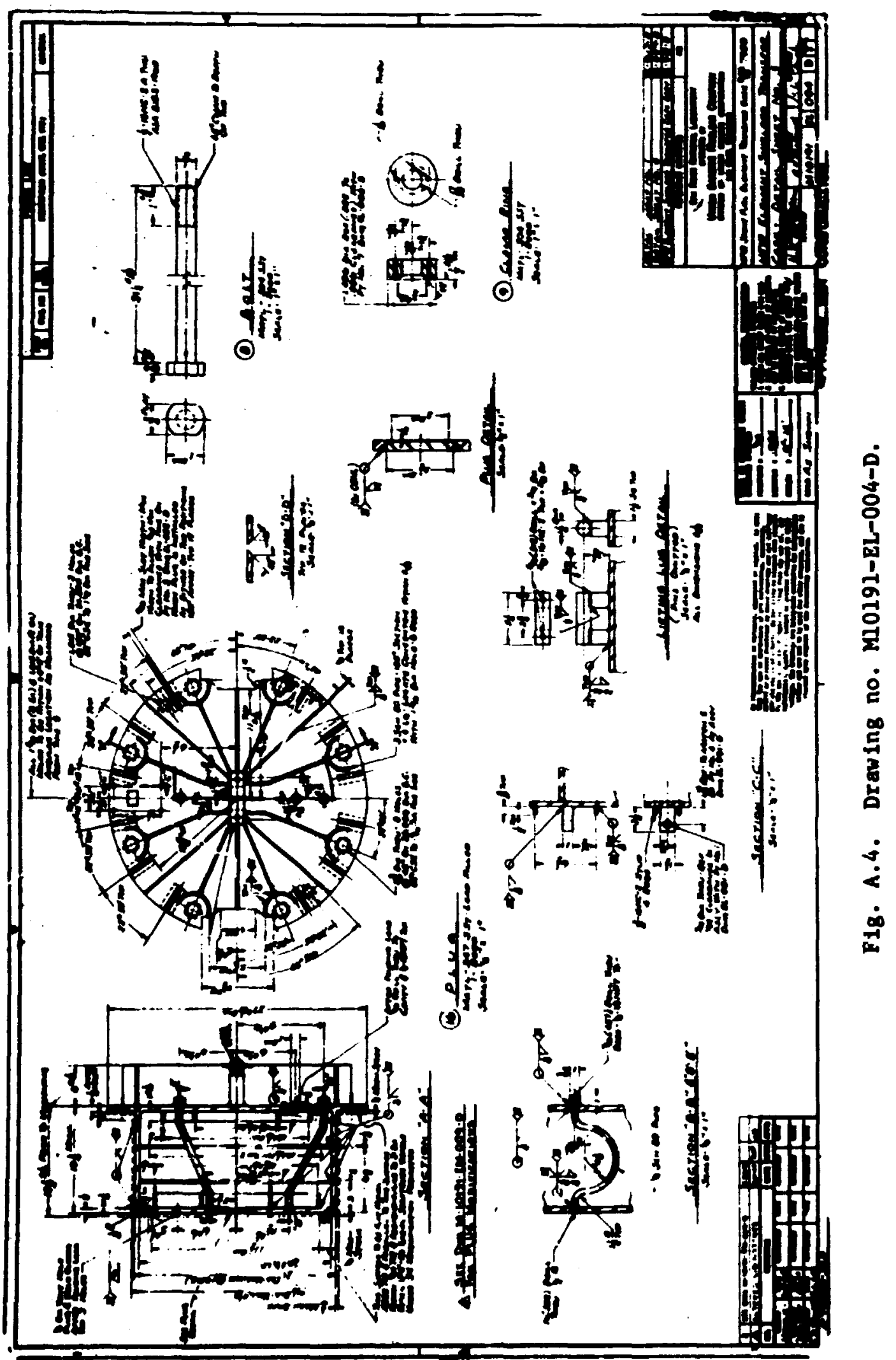


$\cdot a-500-7 a-16$ toth ou 8uFmeda $s \cdot 4 \cdot 3 \mathrm{Td}$

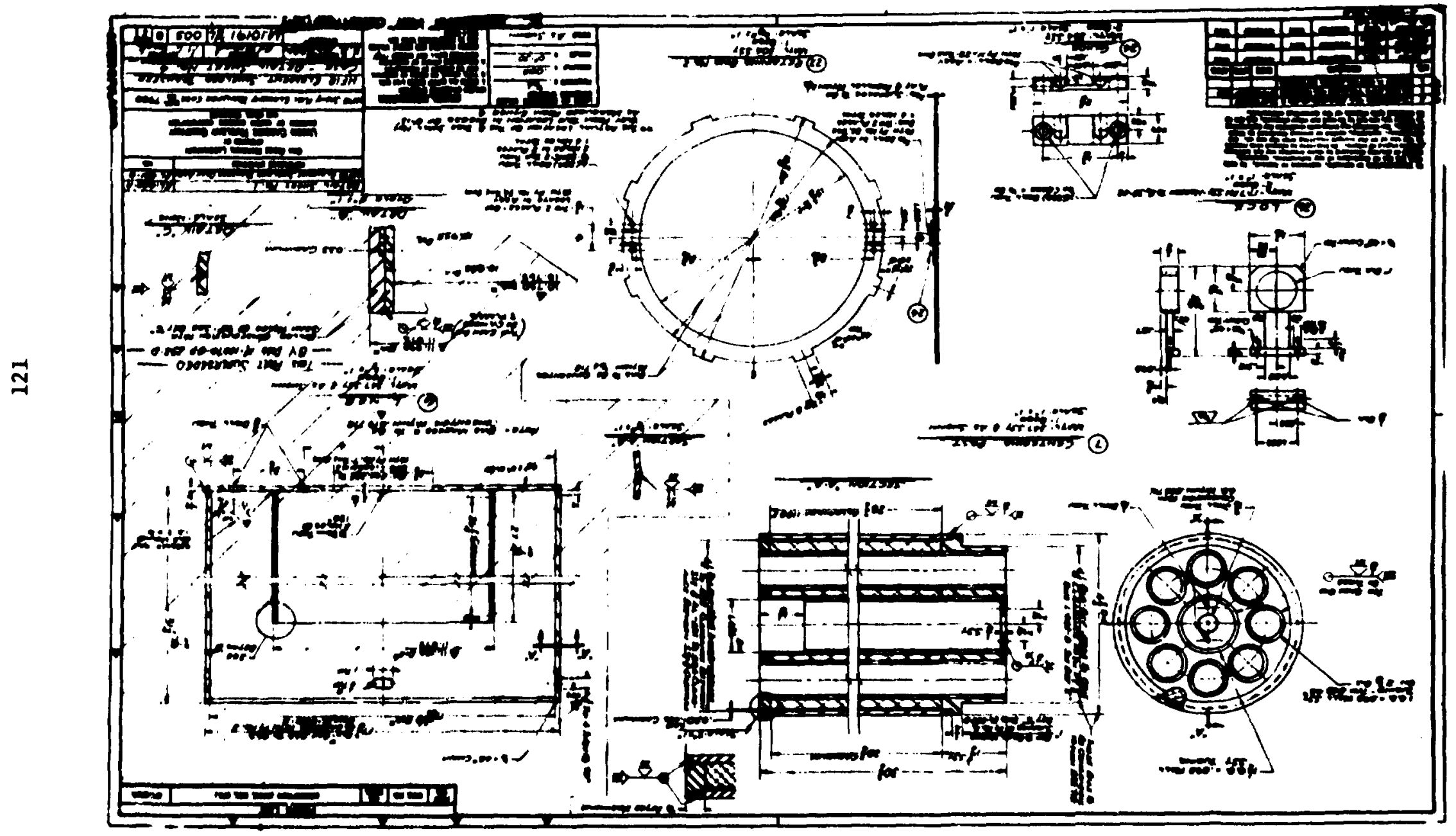




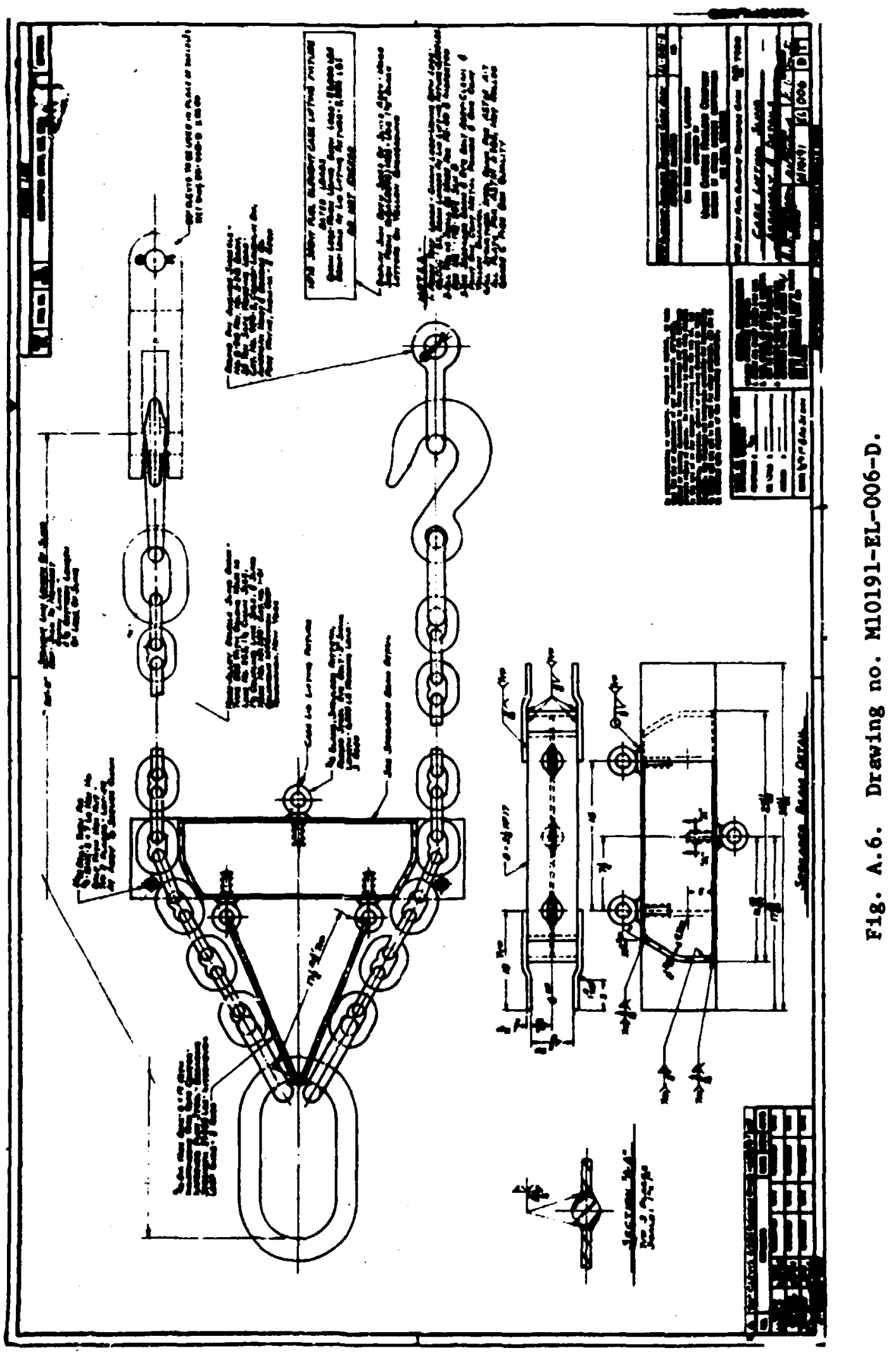




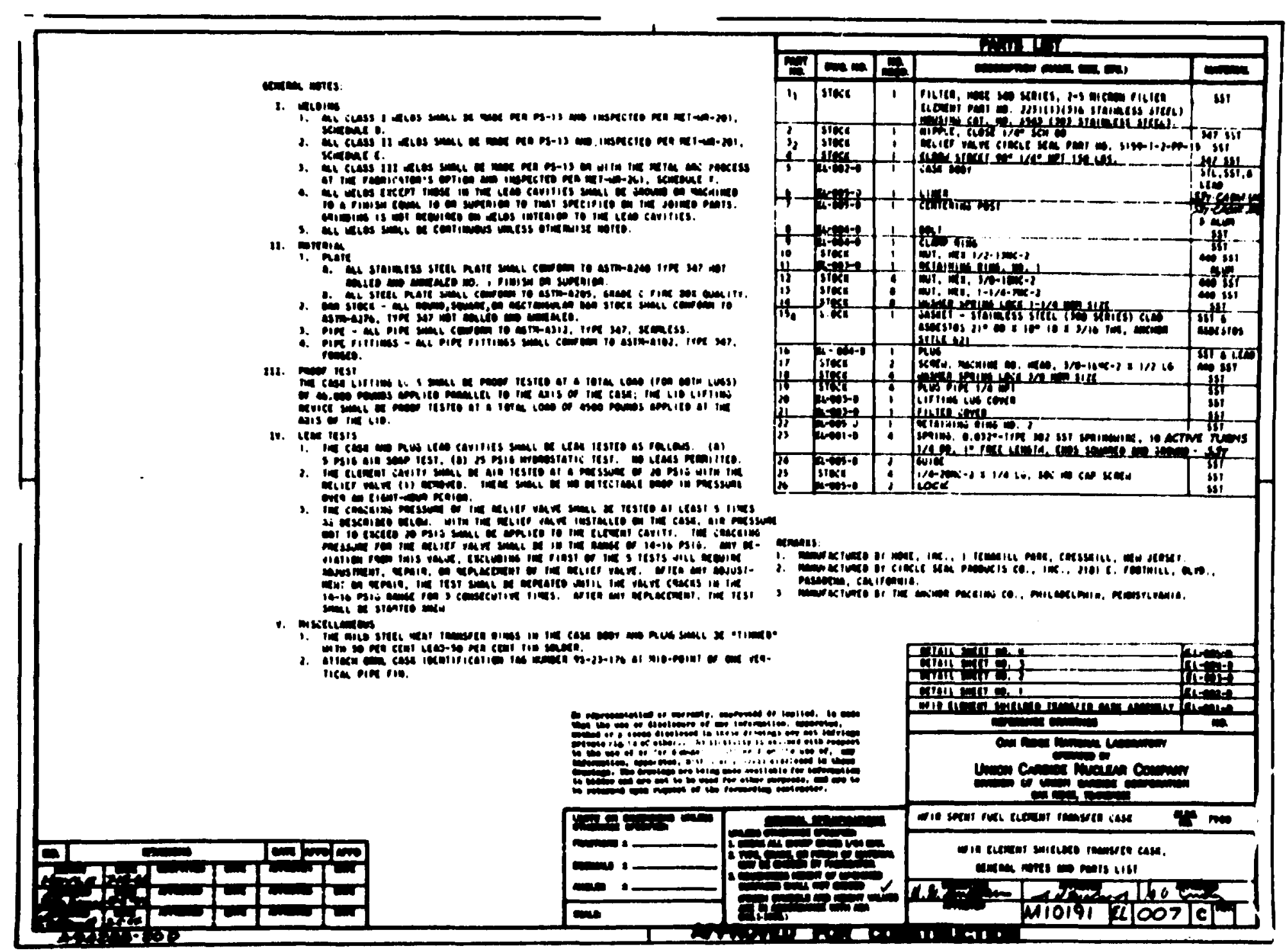

F18. A.7. Drawing no. M10191-EL-007-C. 


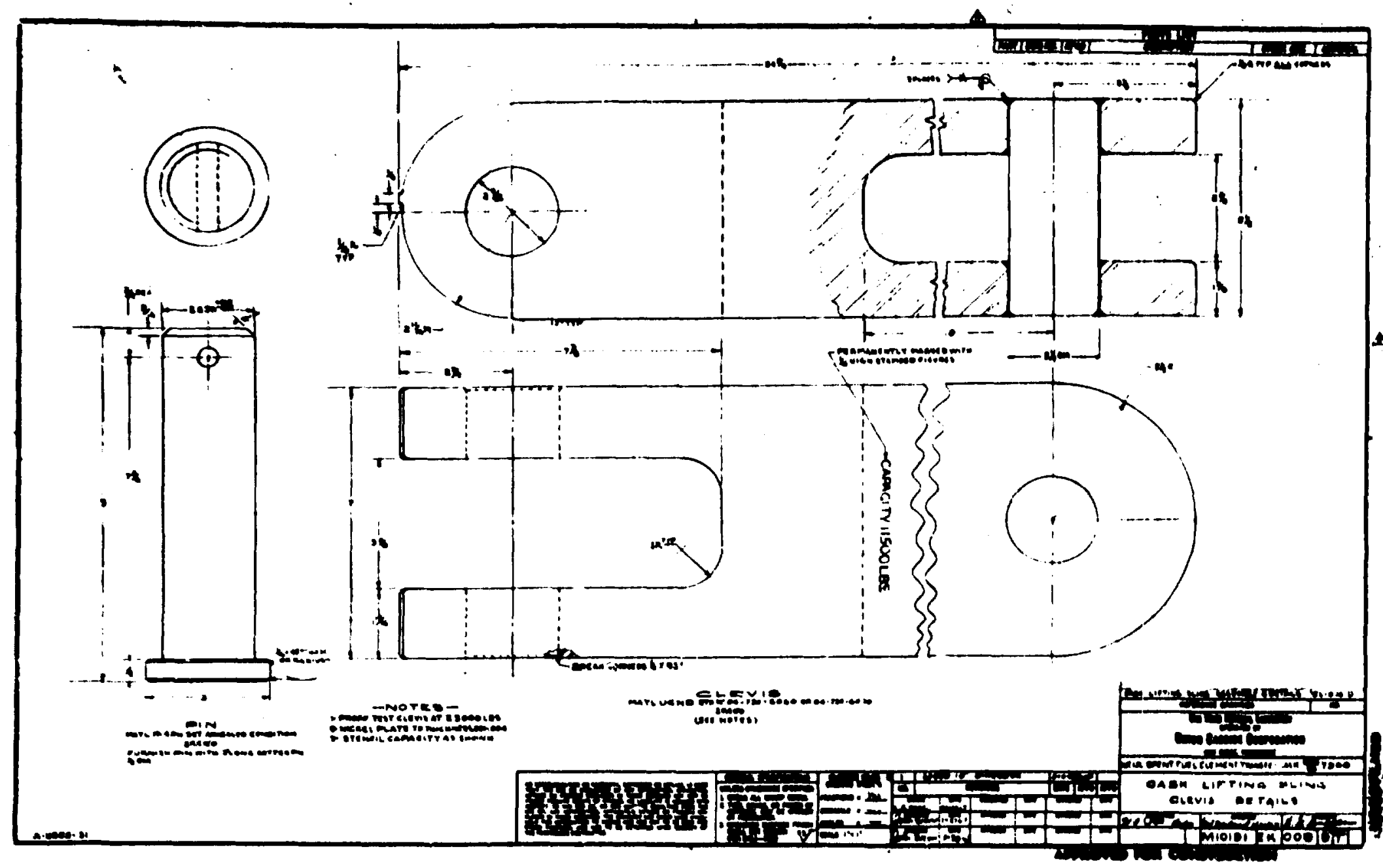

F18. A.8. Drawing no. M10191-EK-008-D. 


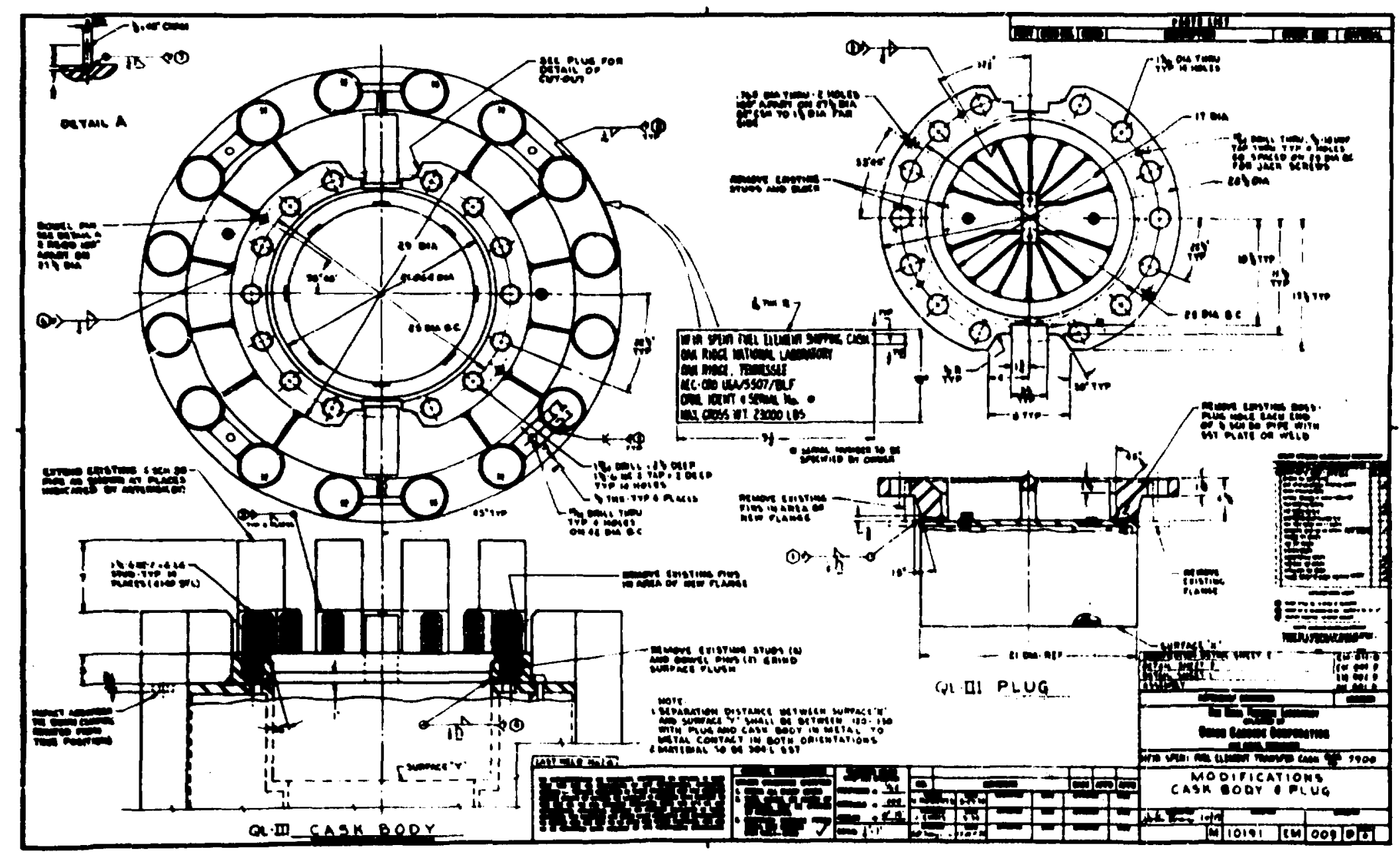

F18. A.9. Draw1ny no. M10191-EM-009-D. 


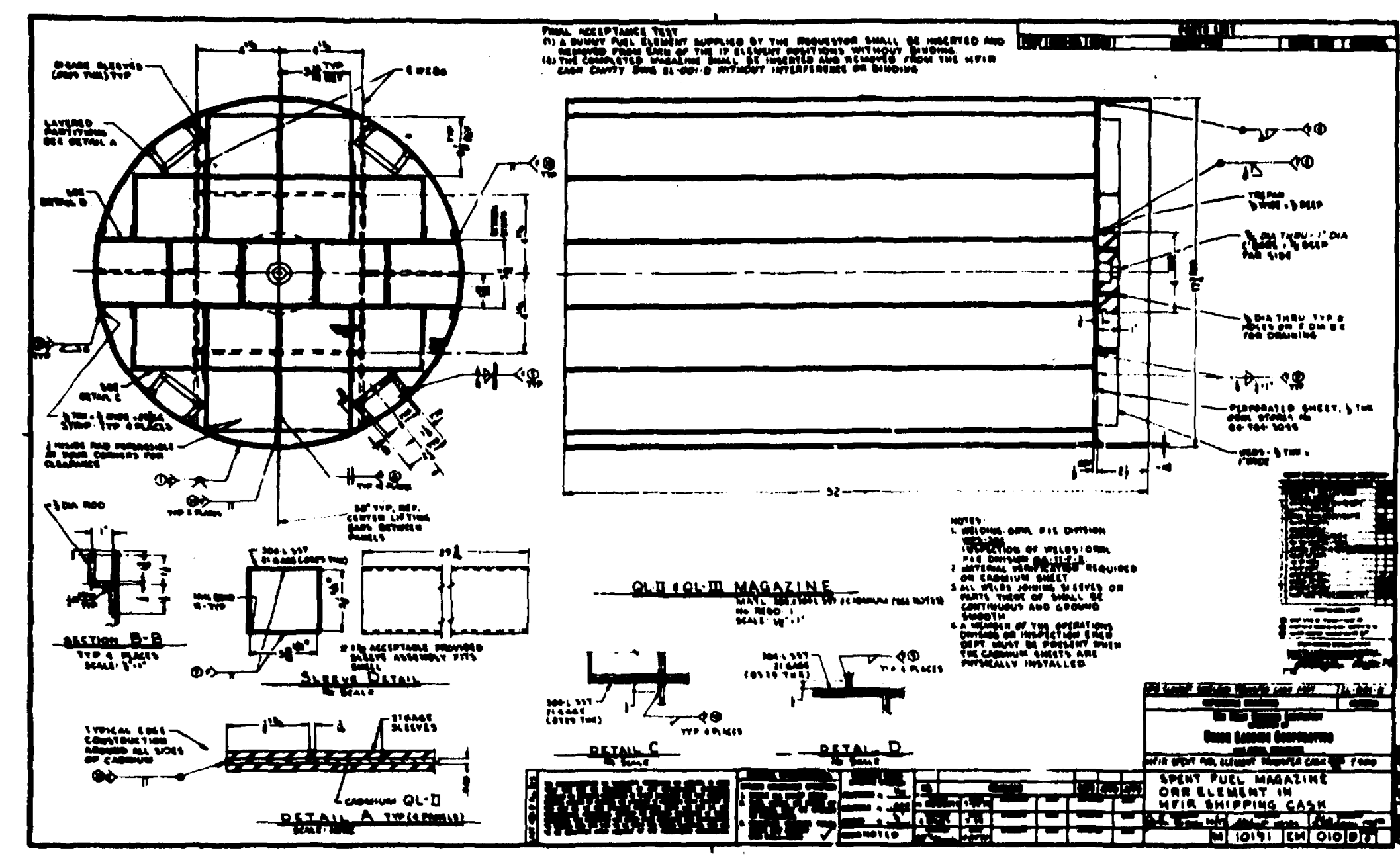

F18. A.10. Drawing no. M10191-BM-010-D. 


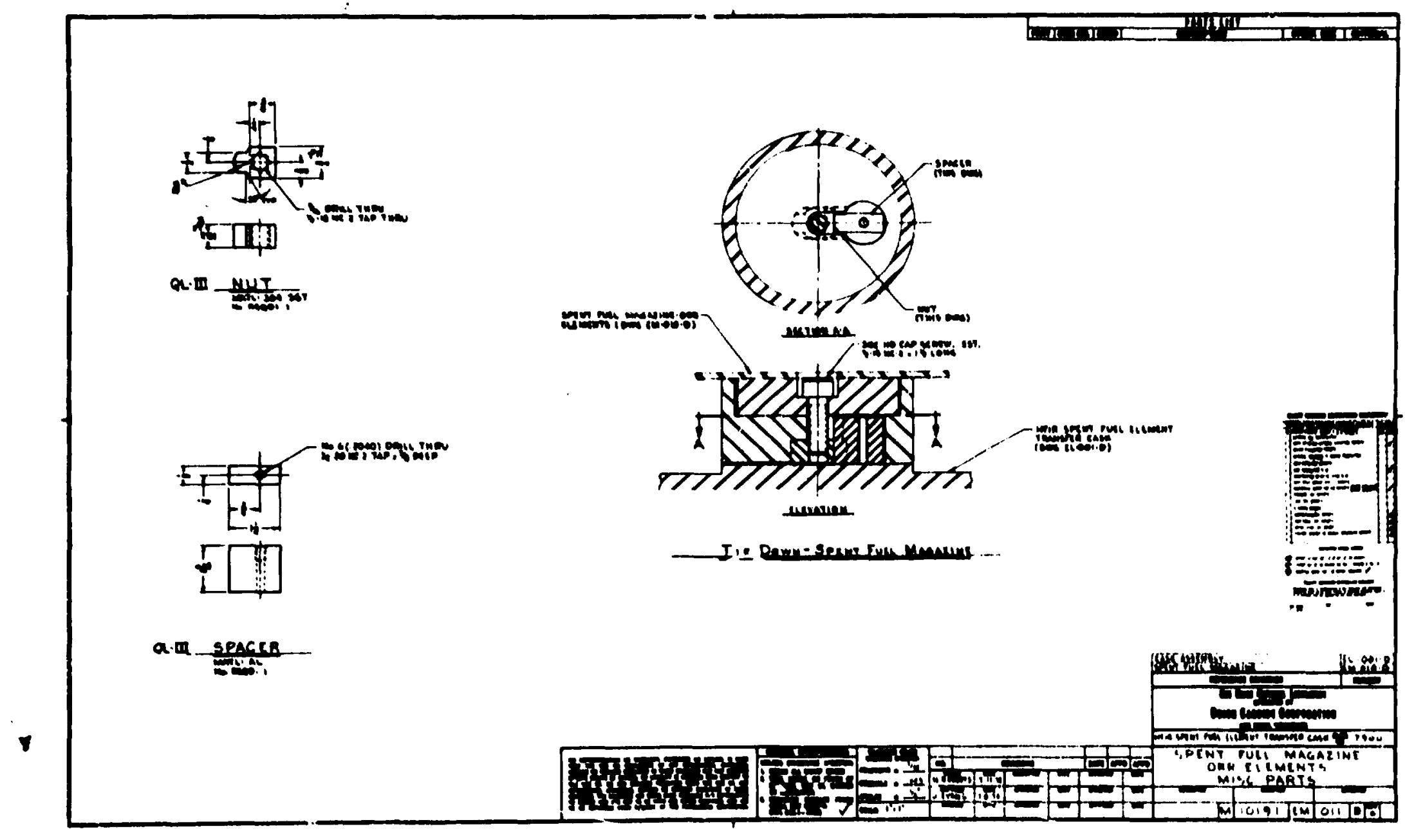

F1g. A.11. Drawing no. M0191-EM-011-D. 


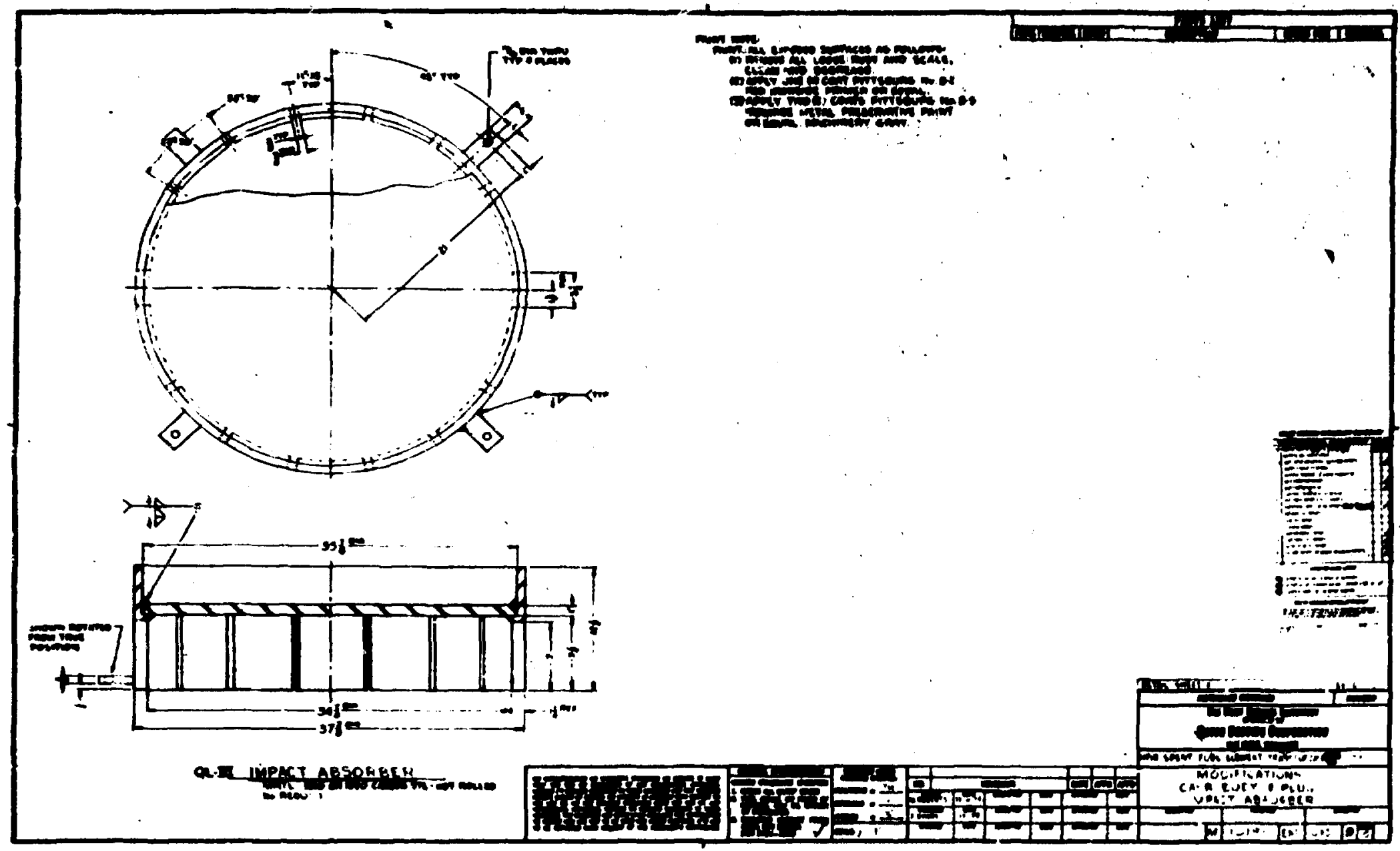

P18. A.12. Drawing no. M10191-ER-012-D. 
- AppenJix B

APPROVAL DOCUMENTS

1. ORNL Transportation Comittee Approval

2. Oak Ridge Operations Office (ORO) Approval 


\section{INTRA-LABORATORY CORRESPONDENCE \\ OAK RDGE MATIONAL LABORATORY}

June 3, 1975

IC $75-1$

To: J. B. Buans, R. V. Hcord

Fron: Transportation Conittes

Subject: Approval of SARP for the OAn BFIR Spent Ruel Elewent Shipping Cast.

The ORUL Transportation Comittee has reviewed your subatssion of the subject SARP to fulfill the requirements (internal review) of paragraph B of ABC Inediate Action Dlrective 5201-3. Particular attention wa given the five areas of structural integrity, the rmal resistance, radiation shieldins, nuclear criticality safety, and quality aesurance.

The regidis of the evaluation show that the cask meets the requiremente of ABCI 057.9 and the SARP is approved for submission to the BRDA for zaqueat of a Certificate of Compliance for approval of the cask for use for offalte shipments of fissile and radioactive materials.

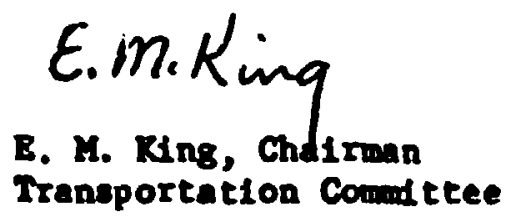

BAL:bb

ce: Transportation Coonttee 


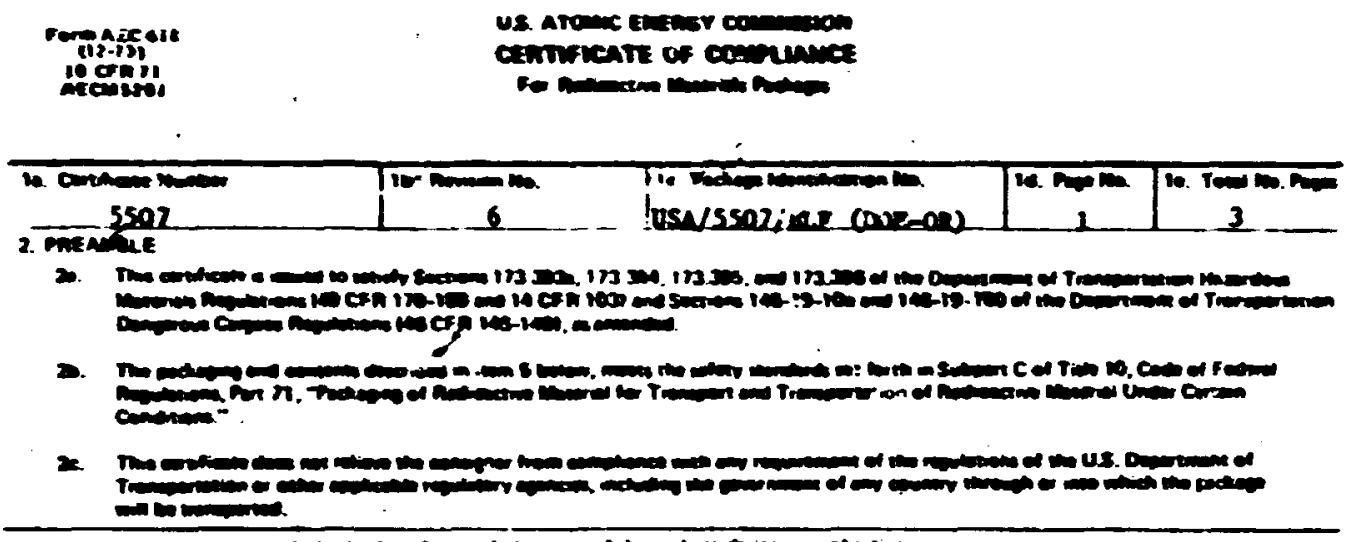

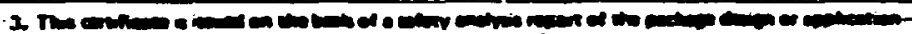

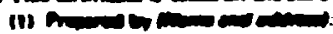

Oak Ride matioan Labotatory

Pont Office bin $X$

Oak ridge, II 37830

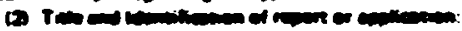

-. Safety analyeis Roport for Pecl Novenber 1977

agios (SNR) - tifth Spent Fuel Element

Shipplas Cank

Leport Ho.: ORH/ENG/TH-12

4 consingos

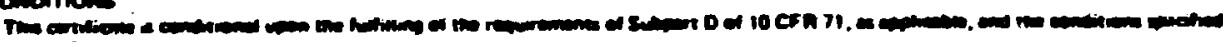

$\rightarrow \sin 8$ entm.

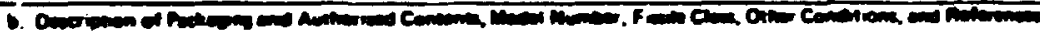

(a) Peckereng:

(1) Model: Uris* Speat Tuel Element Shippins Cask

(2) Descripeion:

Packagin for irradiated fwel elments. The inner cerlty is 17 7/8 in.

dicmetcr $x 32 \mathrm{in}$. deep. The internal configuration is deterniaed by the

spe of tuel elemes beins shipped as follows:

(1) For urtr ful elemats - a renovable post consisting of aluainu wrapper with cadatio is centered in the cavity. The fuel asecably (1 Inner element and I outer element) is positioned in the cavity by concentric fuel besket fabricated of etalnlese steel cled contulu.

(11) Por ORR (Oak RIdge Research Recetor) type fuel elements which also includes DSR (Bulk : leldins Reactor) fuel elemes, for PRR (Puerto Rico Reecarch Reack..) funl eleanais, and for CP-5 (Chicaso PIle Wo. 3) funl assembles - the fuel eleants are posicioned in the corlty by a aagazine fabricated of stainless steel clad cadalum. The center pose is remed.

Hin plux Ieotope Reactor

\begin{tabular}{|c|c|}
\hline 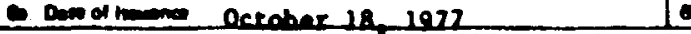 & 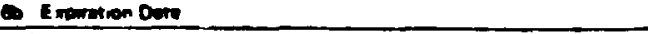 \\
\hline FOA IME US ATOMIC EM & Mengr comission \\
\hline 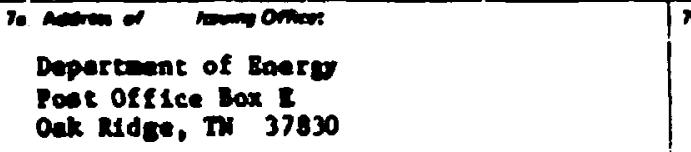 & 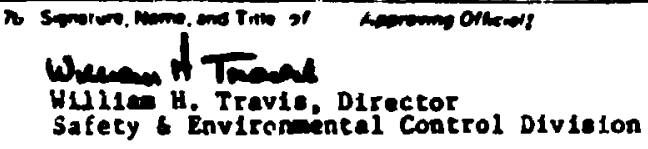 \\
\hline
\end{tabular}


Page 2 - Certificace of Complience, Ho. USA/5507/ULF (DOE-OR), Revision 6

3. (2) A. (Lont Laved)

b. Heorandun fron R. A. Hoser to Hillla H. Travis, December 30, 1975.

c. ilenorandun fron R. K. ibs. $r$ co Hill1a H. Trav1s, October 27, 1976.

5. (Continued)

(1i1) For PRx (Puerto Rico Muclear Center) TRIGA/Flip type fuel astemblies - the fuel asemblied are positioned it che cavity by atcel, elumiau and elastoner basket. The center post is reared.

Shtelding coosists of a noeinal $83 / 4 \mathrm{in}$. thickness af lead betveen 1/2 ta. thick stainless steel inner and outer liner:. Overall dimensions are $46,3,8 \mathrm{ln}$. dianeter $\times 72$ 1/2 in. high. Access to the cavity is through a top plus having $14-11 / 2$ in. alloy steel studs. The gross weight is $23,000 \mathrm{ib}$.

(3) Drewints:

The calk and codificat lons are deacribed in Oak Ridge Nacional Leboretory Drmings: it 10191-EL-001-D through $-006-D,-007-C$, and $-008-D$ chrough 012-D.

The PRUG TRIG:/FLIP fuel basket is tescribed in Argonue National Laboracory Drwing Ho.: $W-0170-0090-0 \mathrm{~s}-00$.

(b) Contente:

(1) Type and Form of Material

Solid, large quantity of radloactive materials, fissile encased in metal cladding as irradiaterl fuel eleoents.

(2) Maxioum quantity of fissile material per package

(1) One HFIR irradiaced fuel assombly containing up to 9,500 \& of $235 \mathrm{~S}$ as uraniun oxice at a $23 \mathrm{~S}$ entichment up to 937 .

(ii) Seventeen ORR-type Irradiatsd fuel elements each containing up to 265 of $23 \mathrm{~S}_{\mathrm{V}}$ as uranium-aluminum alloy at a $235 \mathrm{t}$ enrichoent ap to 932 for a maximue $235_{U}$ content of 4.505 s. 
Pase 3 - Certiflcate of COaplitance, Mo. USA/5507/XF (DOE-UR), Revision 6

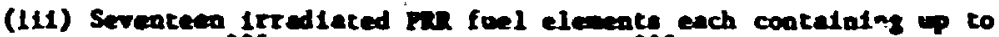
292 of 235 t e urentu oxtde a $23 S_{0}$ enrichent up to 202 for a water $235_{0}$ conceat of 3,264 8 .

(11i1) Seventeen Irrediated All-CP-5 fuel wseblice each containing ep to 170 ere of $235_{0}$ a urealu-nluipue alloy at a $235_{0}$.

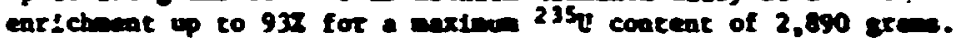

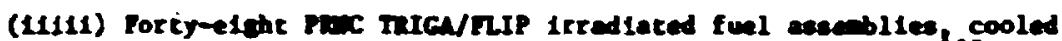

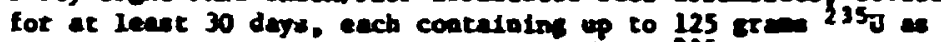
- urantur-zircmile hydride aixture, with a $23 s_{0}$ earichneat of 708, ror a axisin $233_{0}$ content of 6,000 areses.

The hent laed is $\leq 3.75 \mathrm{kw}$.

(c) Pleodie cines.

III

$\bullet$ 


\section{Appendix C \\ ELEMERT DRAWINGS: \\ HFIR-ELEMENT DRAHINGS, ORR ELEMENTS}




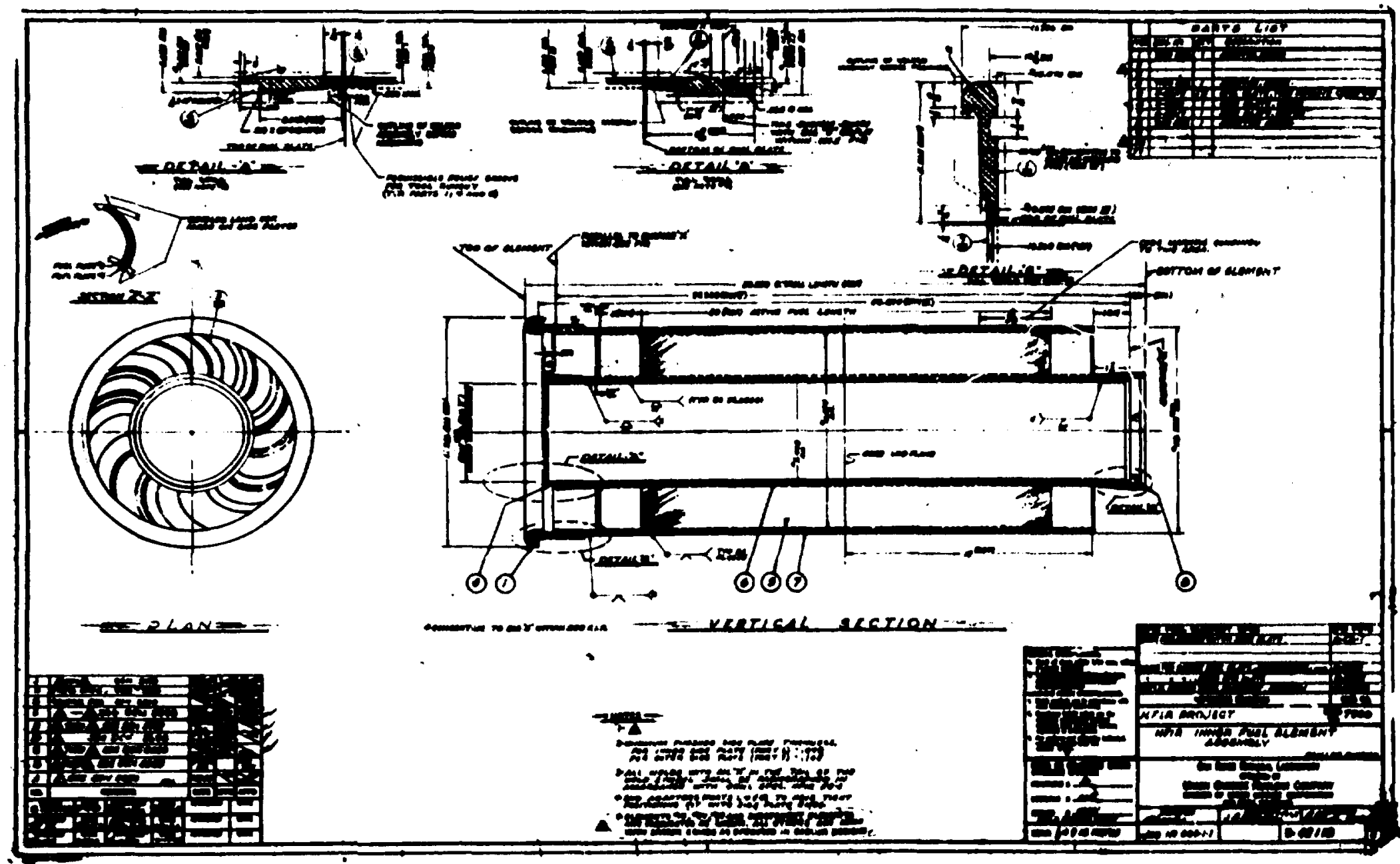

F1g. C. 1. Drawting no. D-42118. 


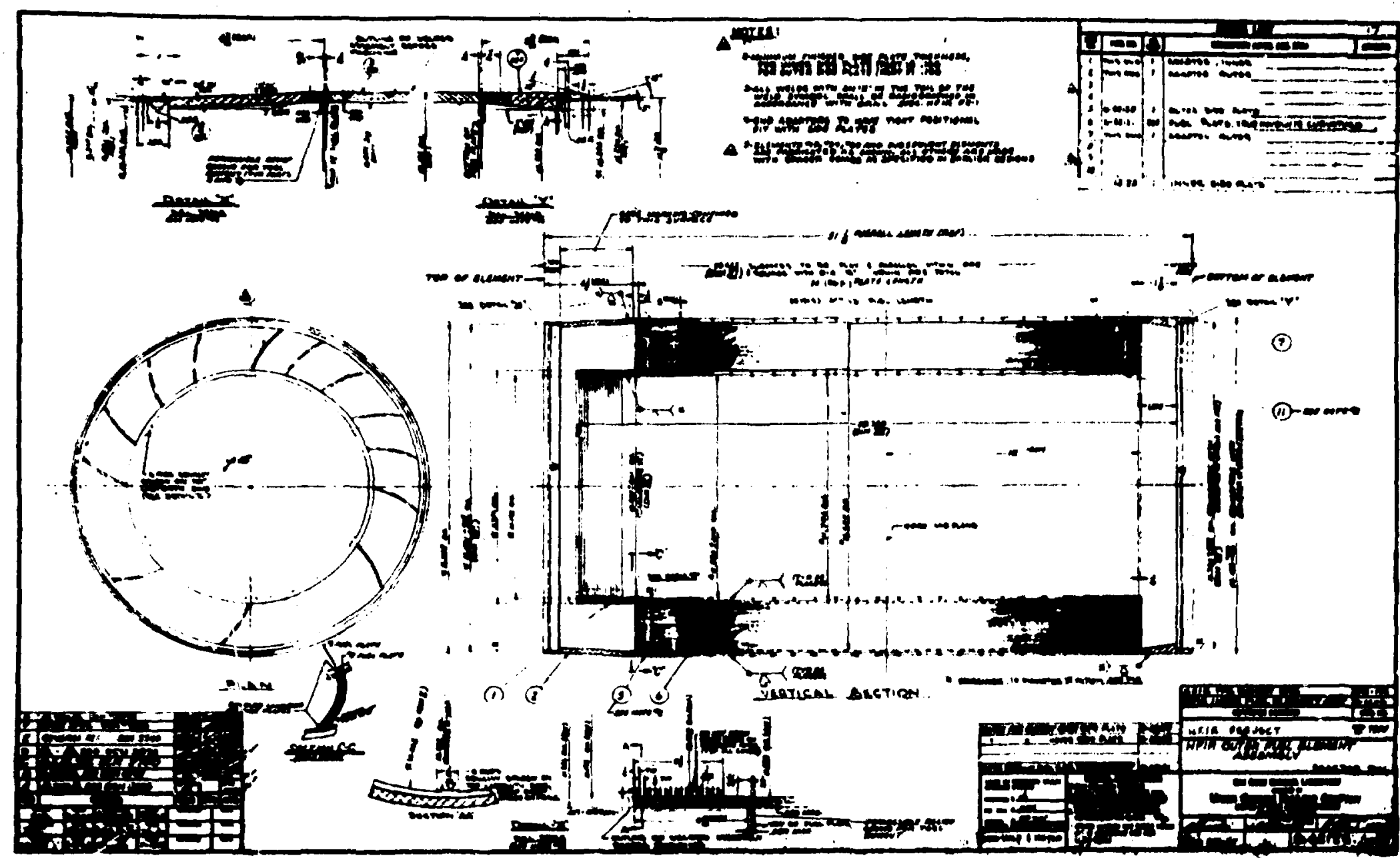

F1g. C.2. Drawing no. D-42126. 


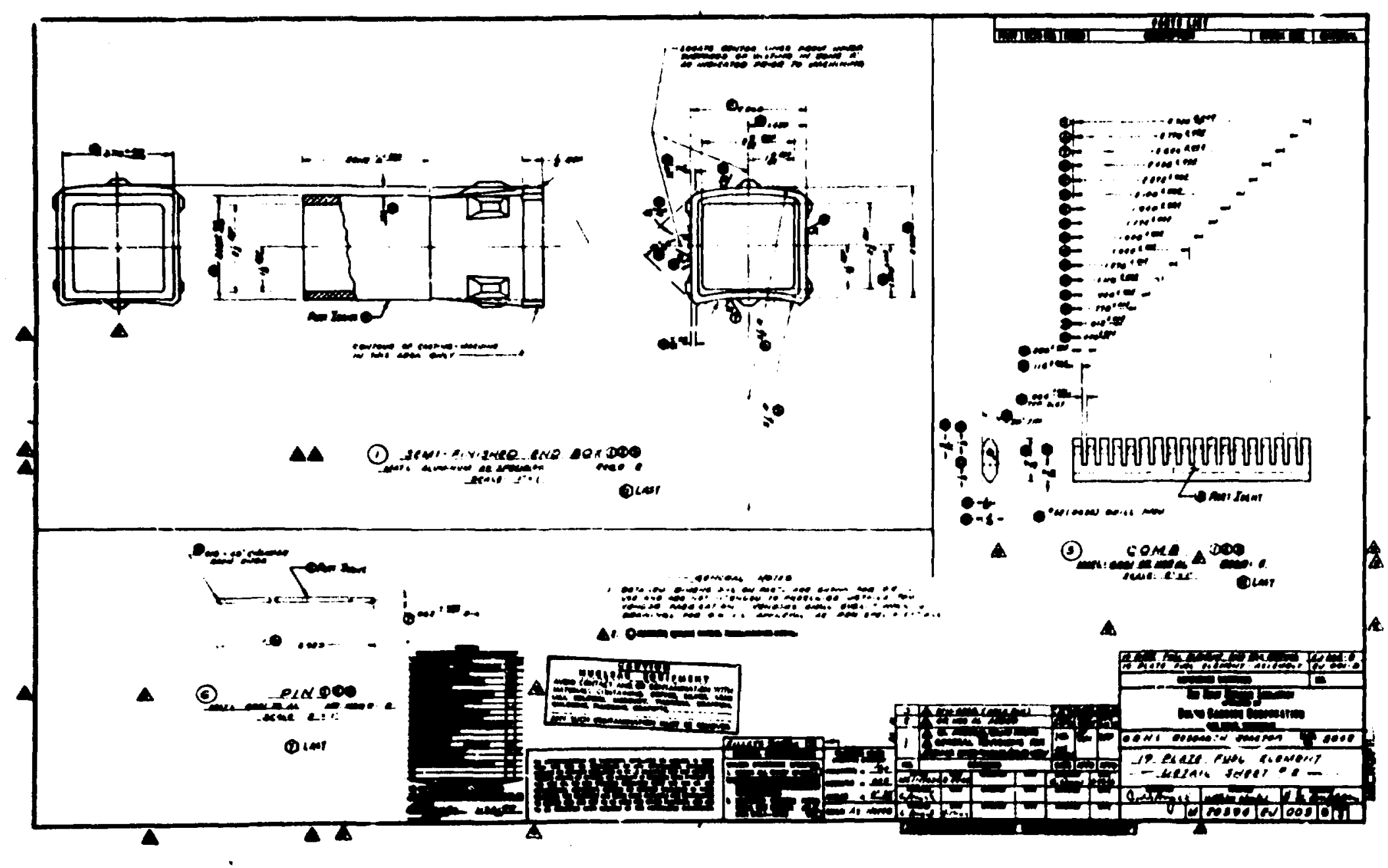

F1g. C.3. Drawing no. M-20394-EJ-003-D. 


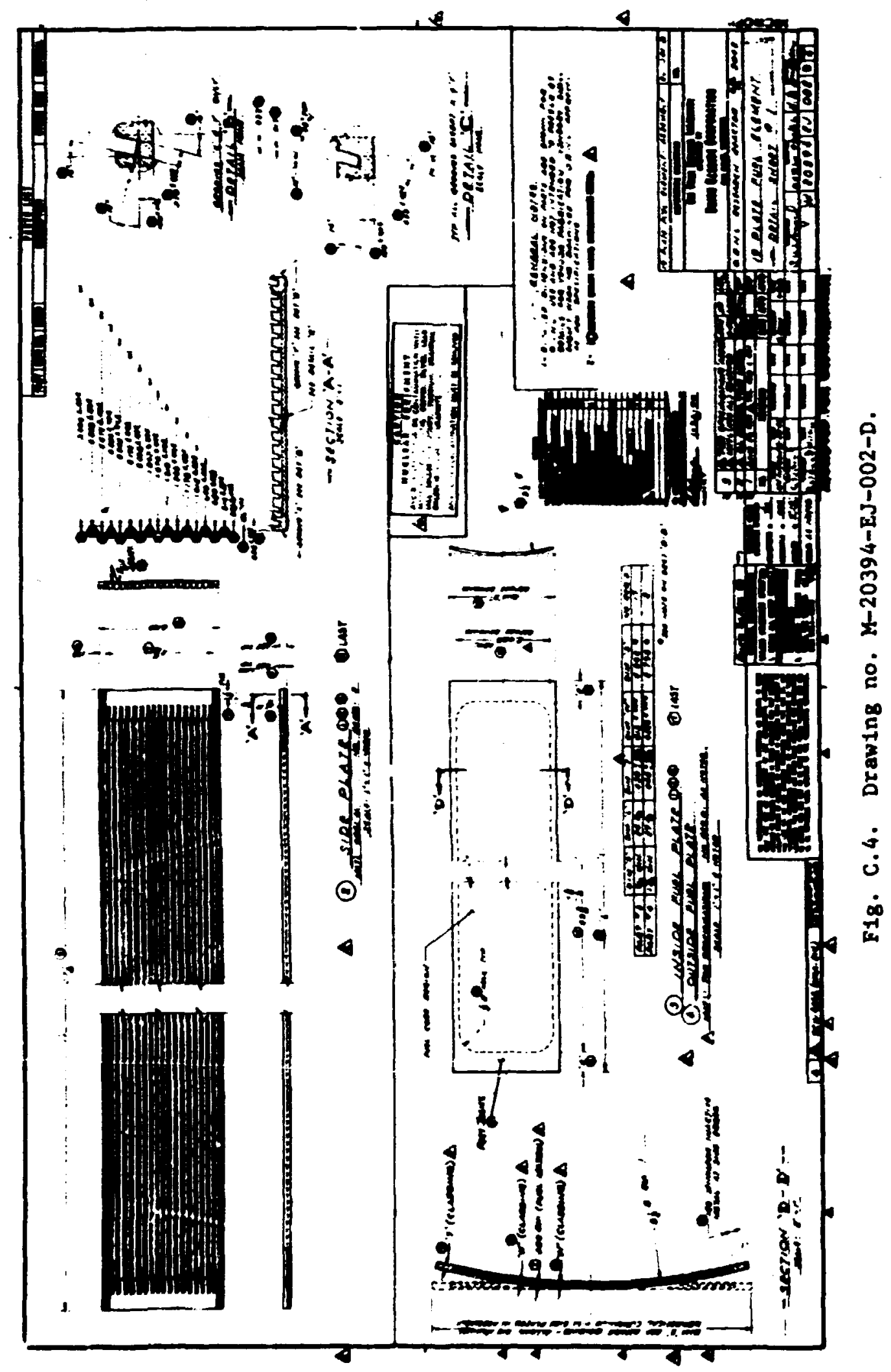




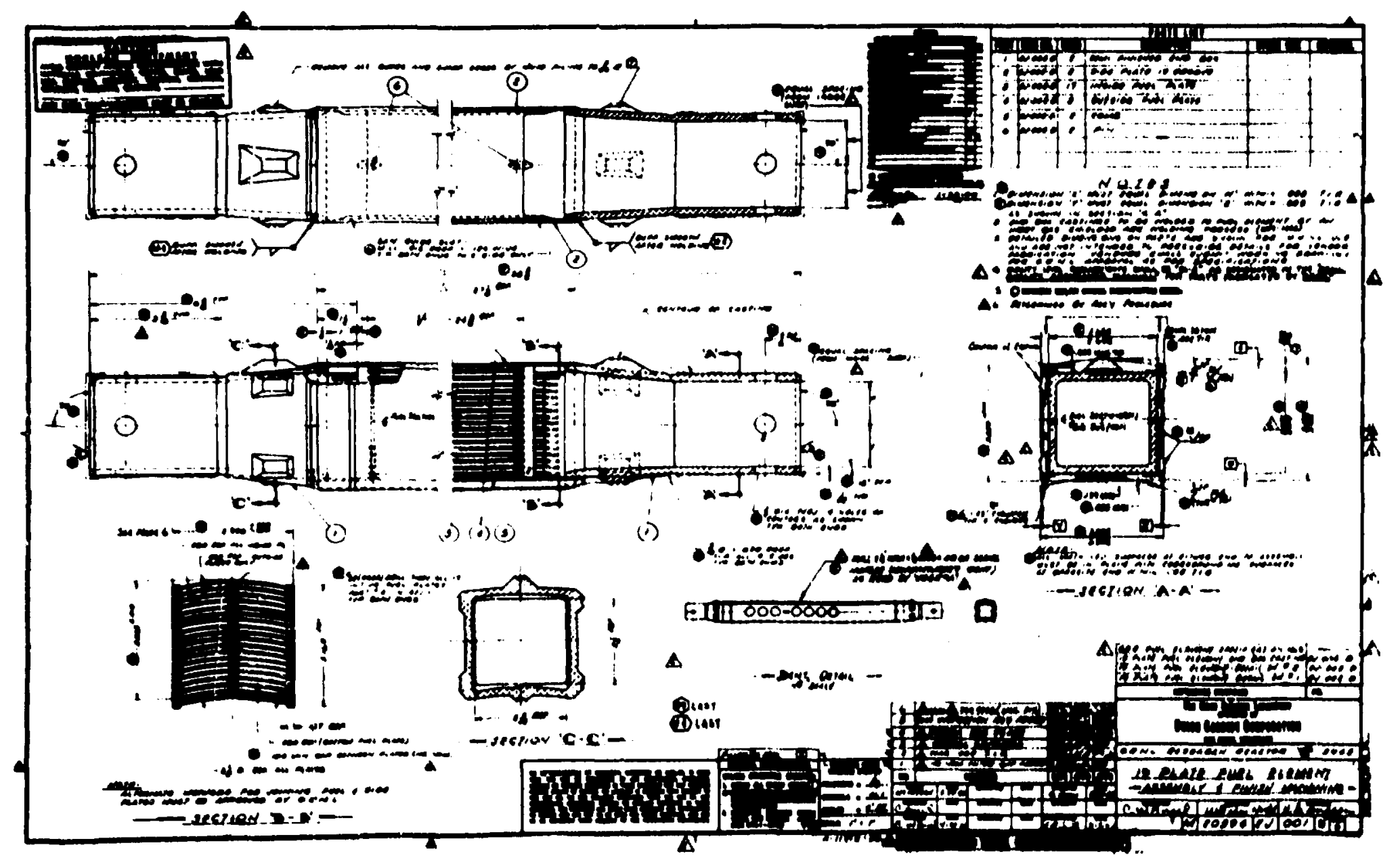

F18. C.5. Drawing no. M-2039.4-EJ-001-D. 


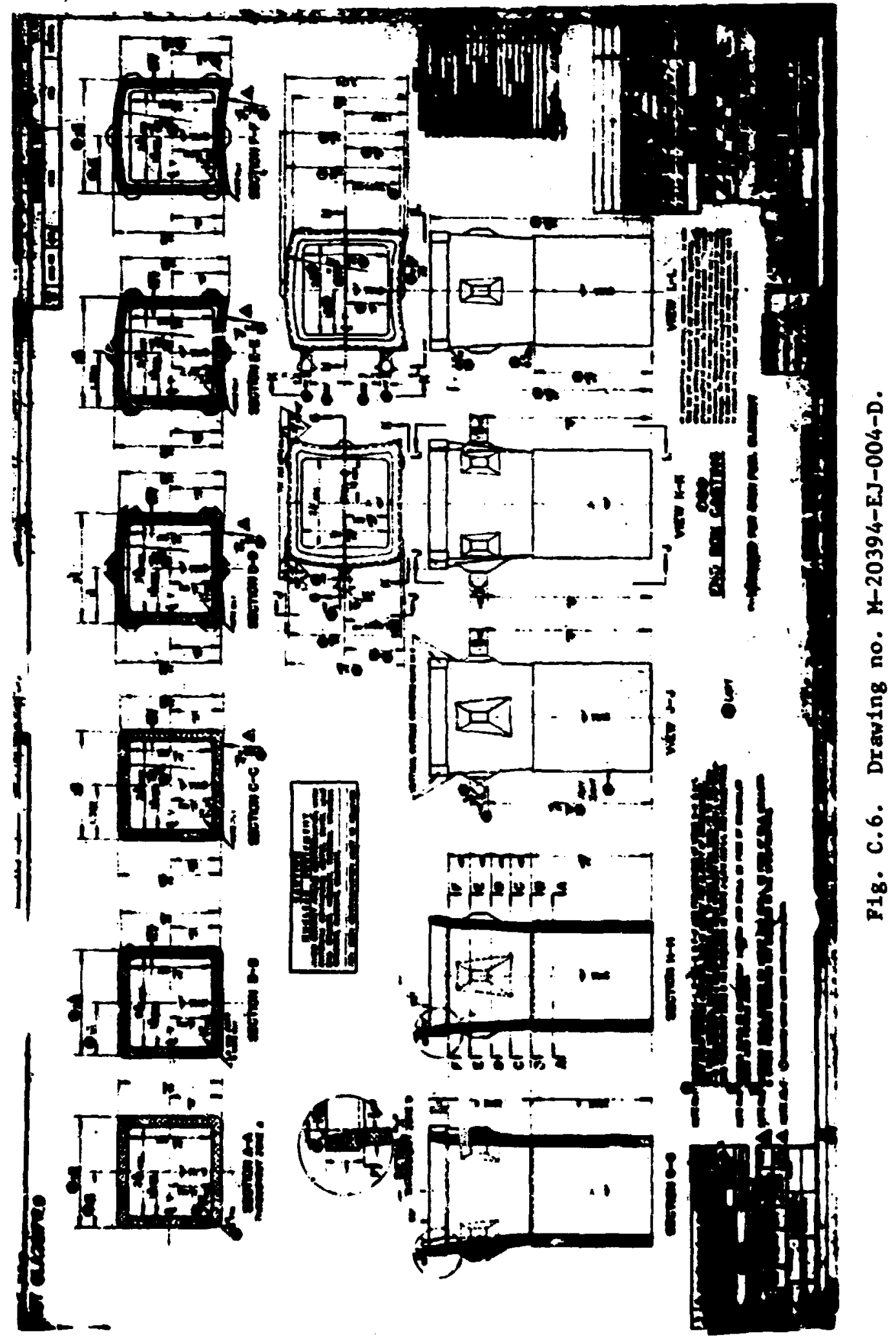


Appendix D

DECAY HEAT CALCULATIONS FOR ORR ELEAENT 


\section{INTRA-LABORATORY CORRESPONDENCE \\ OAK RIDGE NATIONAL LABORATORY}

March 11, 1974

I0: F. T. BLiford

FROY: T. P. Hawrick

SUBJECT: Deteralnation of EGergJ Release frod a Shigle ORR Fuel Element as a Function of Decay Time

In order to determine the energy released from a stagle ORR fuel element during its decay period prior to shipzent for reprocessing, some assumpthons wist be wade regarding its history during reactor operation.

Aseumption:

1. The elasent is assumed to remain in the reactor throurhout its life. In reailty, the element is cycled in and out of the reactor in varfous core positions depending on the amount of $235 \mathrm{U}$ remaining.

2. The cicment produces one negawatt of fower during reactor operation. In reailty, tile clement produces more at the beginning of $11 \mathrm{fe}$. However, since the elcment is in a low flux position at beginning of $l i f e$ and a high flux position at and of life, the power produced by the element can be assured to bs constant.

3. The elcment is in the reactor for one hundred (100) days during 1 ts 11fetime. This assumption is based on the fact that approximately one hunired twenty (120) grams of 235U has been conolmed by burnup and conversion ro $236 \mathrm{U}$.

Approach to the Problem

Wuch has been uritten regerding the decay of flssion products. Advantage was taken of four previous investigations.

\section{Nay-Wignex}

Wey and Whener suggested a elmple expreselinn for the decay of fleston products. (1) This expression has been modiefed as follows: (2)

$$
\frac{P}{P_{0}}=6.1 \times 10^{-3}\left[\left(\tau-T_{0}\right)^{-0.2}-T^{-0.2}\right]
$$


where $P$ and $P_{0}$ can be expressed in any conventent, but identical units, elnce the ratlo is dimensionless. In the expression, $t-T_{0}$ is the time In days after shutdown, I.e., the cooling period, and $t$ is the total the in days from stạtup to the end bf the cooling tise.

Inder the assumptions previously IIsted, the expr:ssion can be further codffied to:

$$
2=5.1 \times 10^{3}\left[(\tau-100)^{-0.2}-\tau^{-0.2}\right] \text { vatte }
$$

where $P$ is the energy produced by the fuel elerient when $P_{0} \perp 81.0 \times 10^{6}$ vates. PIgure 1 shows the relationship between energy produced and tine after shutdown using the Way-Higner expression.

\section{Rexkins and King}

Perkins and Kin.'s's eariler work (3) was refroduced in part In the Reactor Handbool (4), and it was this source that was used. An error In the reproduction of the curves for the decay rates after shutdown of the reactor operating at 1 watt for $1,10,100$, and 1000 hours was diecsvered. The curve labeled " $D$ " in the set of curves is listed in the Reactor Handibook as the total disintcgration energs which would lead one to belicve that the units are Hev/ses-watt as shown in the figures. If one refers to the orfinal article by Peskins and king on page 738 under results, they say:

MThe ordinates are labeled $\mathrm{Hev} / \mathrm{sec}$, corresponding to energy release; the curve for total disintegration rate is in units of disintegrartons per second, using the sare numerlcal ecale."

For this reason, new curves were construated using the total disintegration by adding the cotal $B$ and the total $/$ disintegration energes for $1,10,100$, and 1000 houre of reactor operation yrlor to sbutdown. These curves were comblned and extrapoloted to form a n curve for 2400 hours (100 days) of reactor operation prior to shutdown. This curve 18 shom in Plgure 2.

Points were read from this extrapolated curve and calculated in the tane unite as FIgure 1. These resulte are hown in BIgure 3. Since accurecy is lost due to reading ceveral points from several graphs and extrapolating, apthod of dece swoothing was uned to obtatn the resulte in Figure $3 .(5)$ 
ORML DWe 77-19600

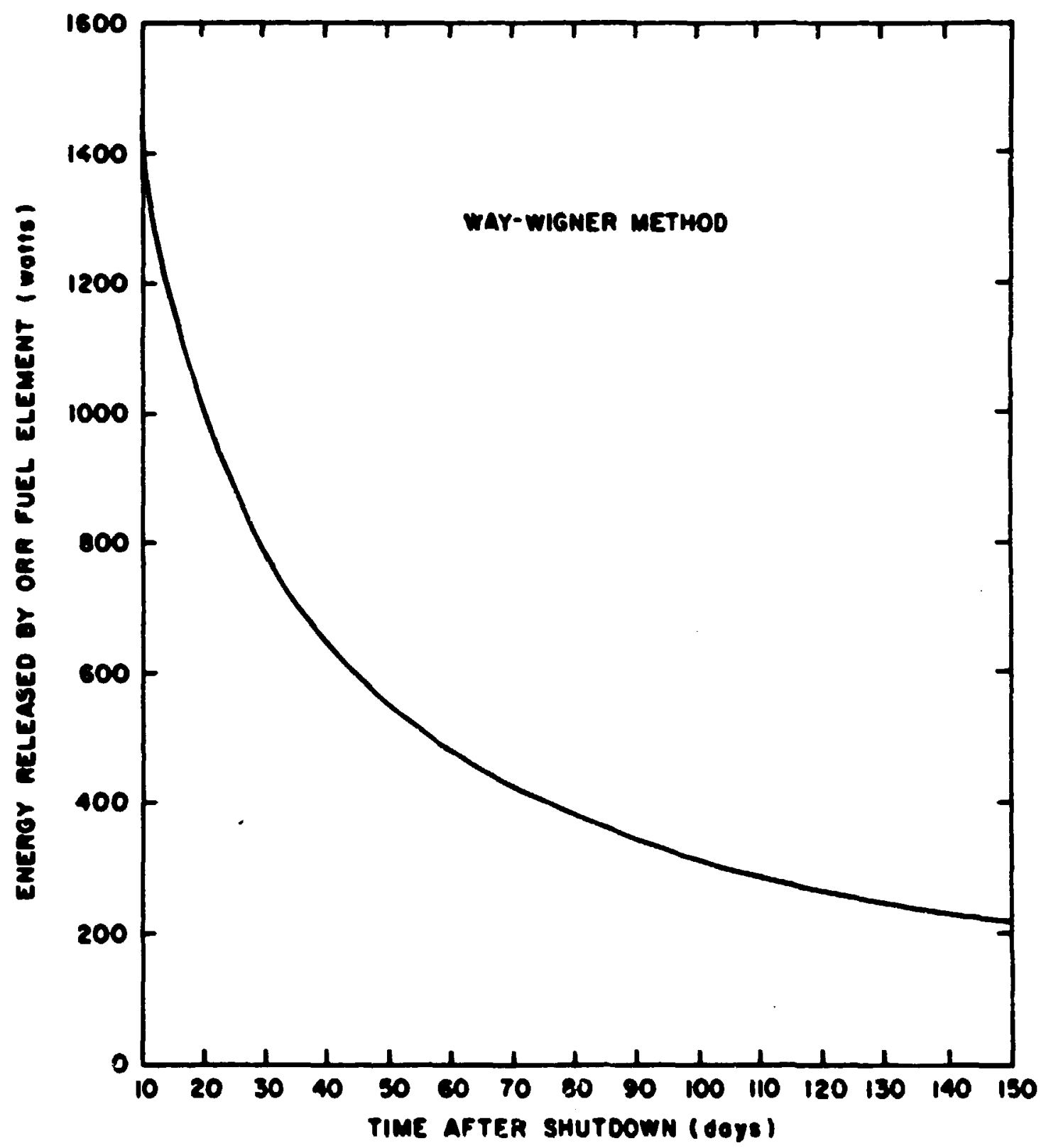

F1g. 1. Energy release by one ORR fuel element as a function of cooling time after reactur shutdown (Hay-W1gner wethod). 


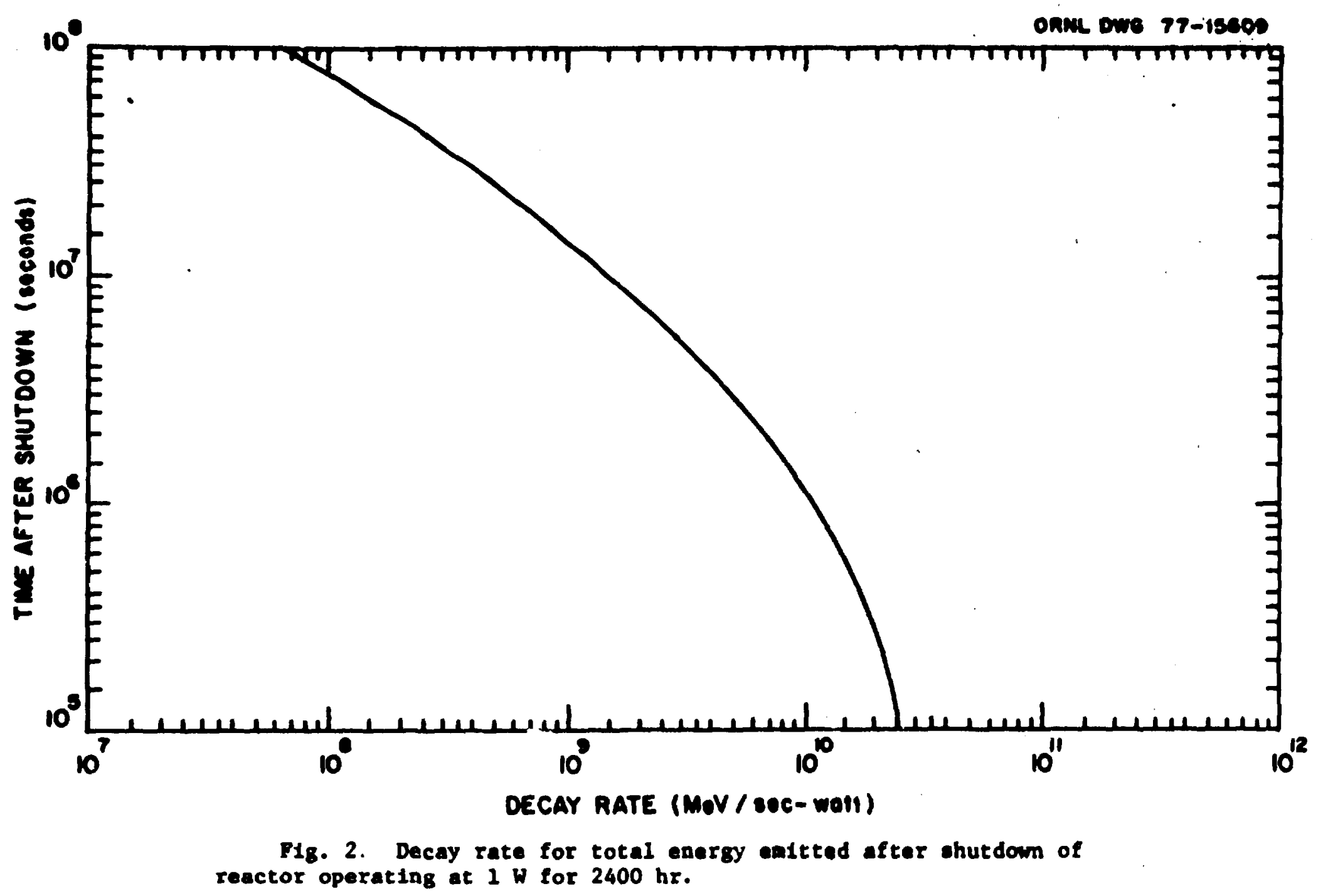


OnwL Dwe 77-15610

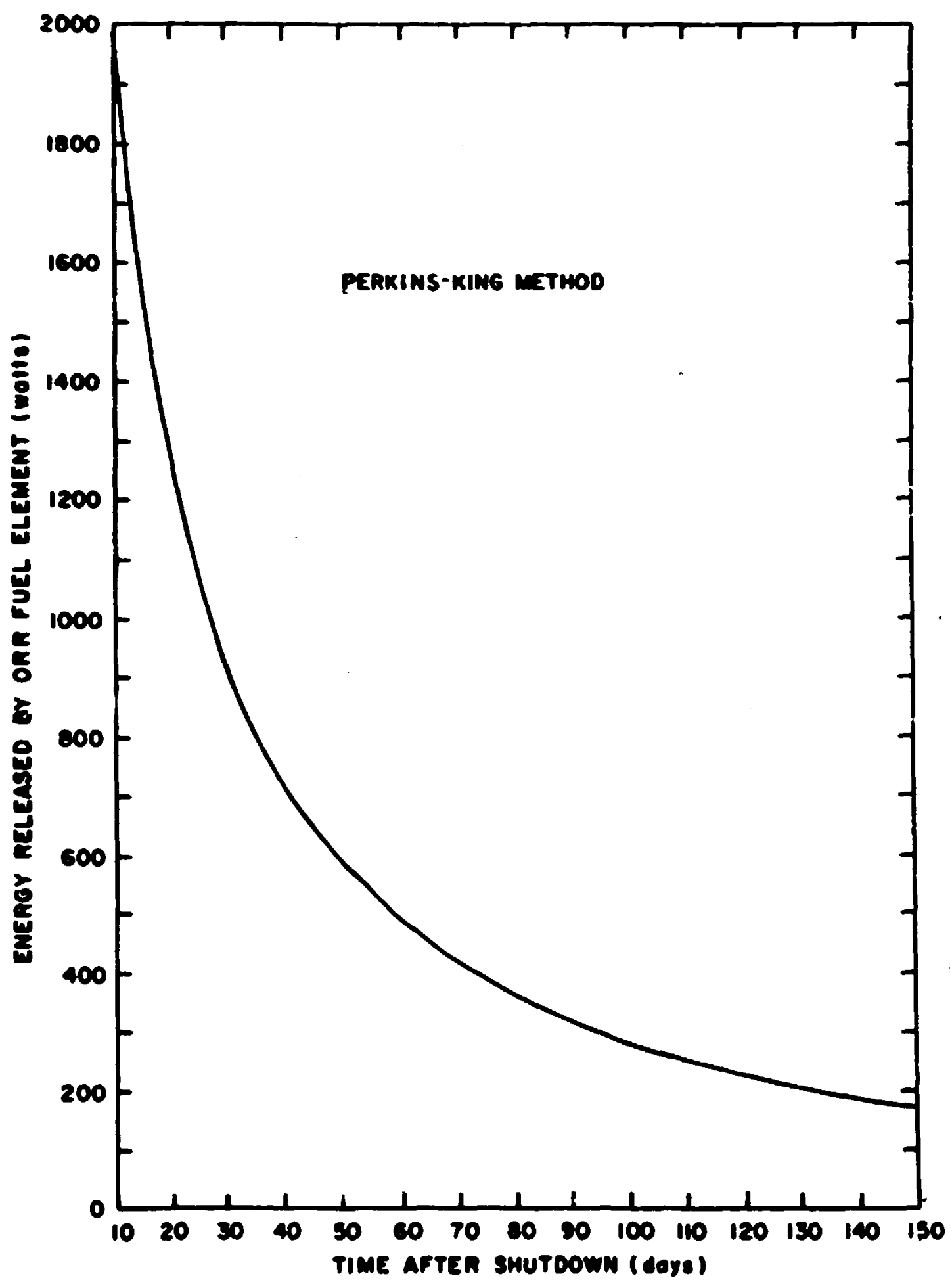

P18. 3. Energy released by one ORR fuel elenent as a function of coollng tine after reactor shutdown (Perkins-Ring wethod). 


\section{Blomeke and Todd}

Bloseke and Todd ${ }^{(6)}$ show the relationship of total fission product power as a function of irradiation time and shutdown tive for various theraal neutron fluses. As in the case of the Perkins and king data mentiontd previously, 1t was necessary to construct a new curve for an irradiation tive of 100 days from the graph preserted on page 357 of the reference. since the average flux to which the elepent is exposed is for all practical purposes near $1 \times 10^{14} \mathrm{n} / \mathrm{cm}^{2} / \mathrm{sec}$, this curve was used without nodiflcation. The san smoothing wethod was used as in the case of the Perkins and King data. The results of the analysis are shown in Pigures 4 and 5 .

\section{Shappert}

* The final nethod used by Shappert (7) consists of a coubination of a coputer code and experisuental data for calculating deca: heat. is In the case of Perkins and King and Blogeke and Todd, it was necessary to extrapolate Shappert's curve to a 100-day reactor operating tise using Figure 5.1 on page 127 of the reference material. These results are shown in Figure 6.

Copparison of Results

Table 1 sho is the comparison of the four rethods studied. Figure 7 is a graphical comparlson of all the methods studicd. The $95 \%$ sonfidence level was calculated using the average of the four methods as the correct result. On this basis, the accuracy of a single deternination for any one of the four methods at the 95\% confidence level would be:

$$
\begin{array}{ll}
\text { Uay-Higner } & -5 \pm i 2 z \\
\text { Pexk1us-KIng } & -6 \pm i 17 \\
\text { Blomeke-Todd } & +10 \pm 5 \pi \\
\text { Shappert } & +2 \pm 5 z
\end{array}
$$

We can be. Ealrly certaln that an ORR fuel elenent after 100 days dacay w1It be generating $319 \pm 52$ watts of energy.

Buplrically, the energ production can be repreaented by a 3 half-life inture

$$
P=705\left(e^{-0.008105 t}+2.027 e^{-0.048462 t}+2.189 e^{-0.198 t}\right) \text { wates }
$$

where $t$ is the the after reector ahutdown in days.

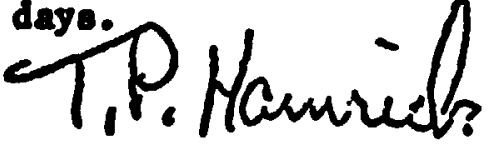

Ithex

$$
\text { I. B. Bamelck }
$$

$\begin{array}{ll}\text { C. D. Cagle } & \text { 8. 8. Hurt } \\ \text { v. R. Casto } & \text { J. H. Swanks } \\ \text { J. A. Cox } & \text { J. H. Evans }\end{array}$




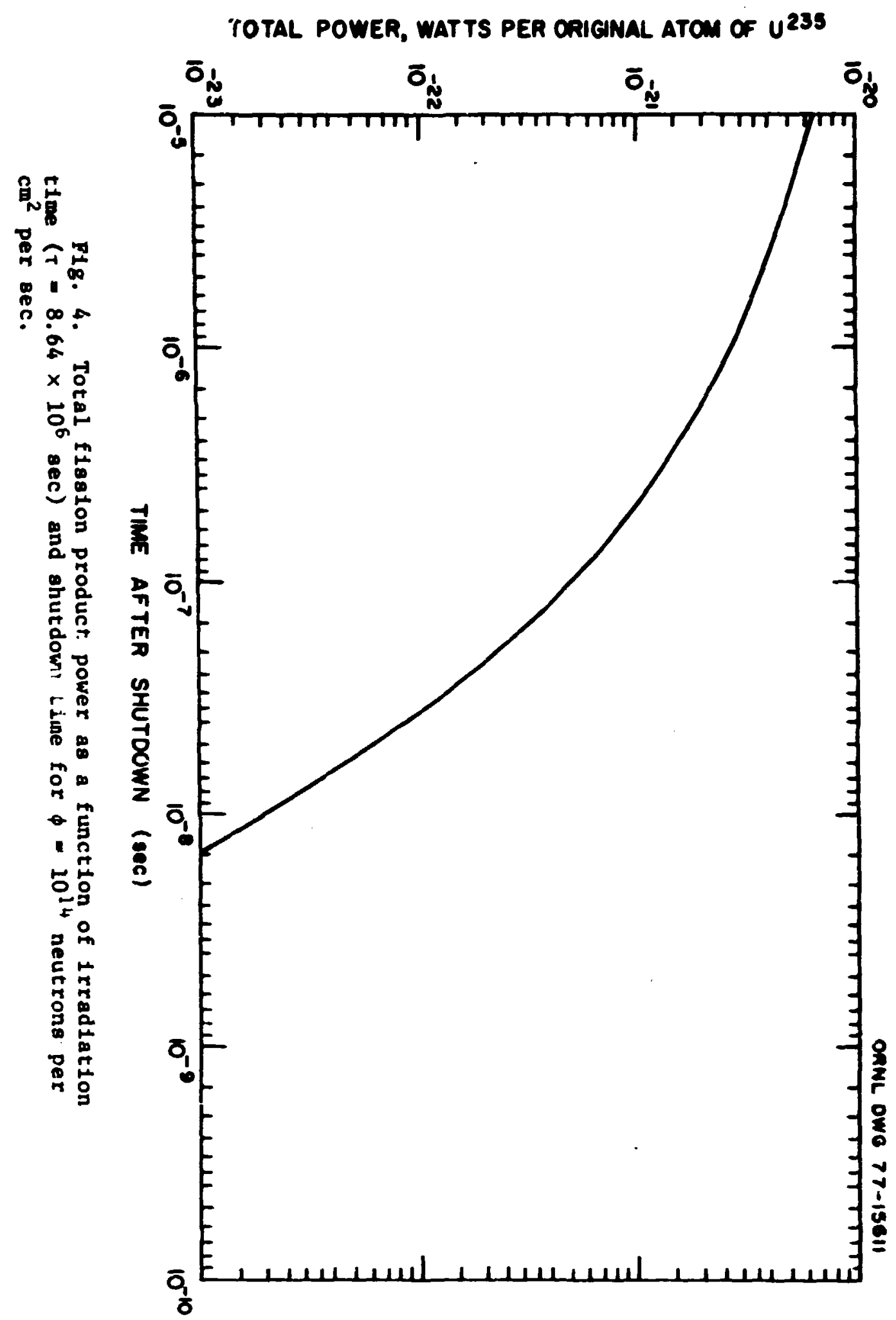


OnNLL Dwa 77-ISBI2

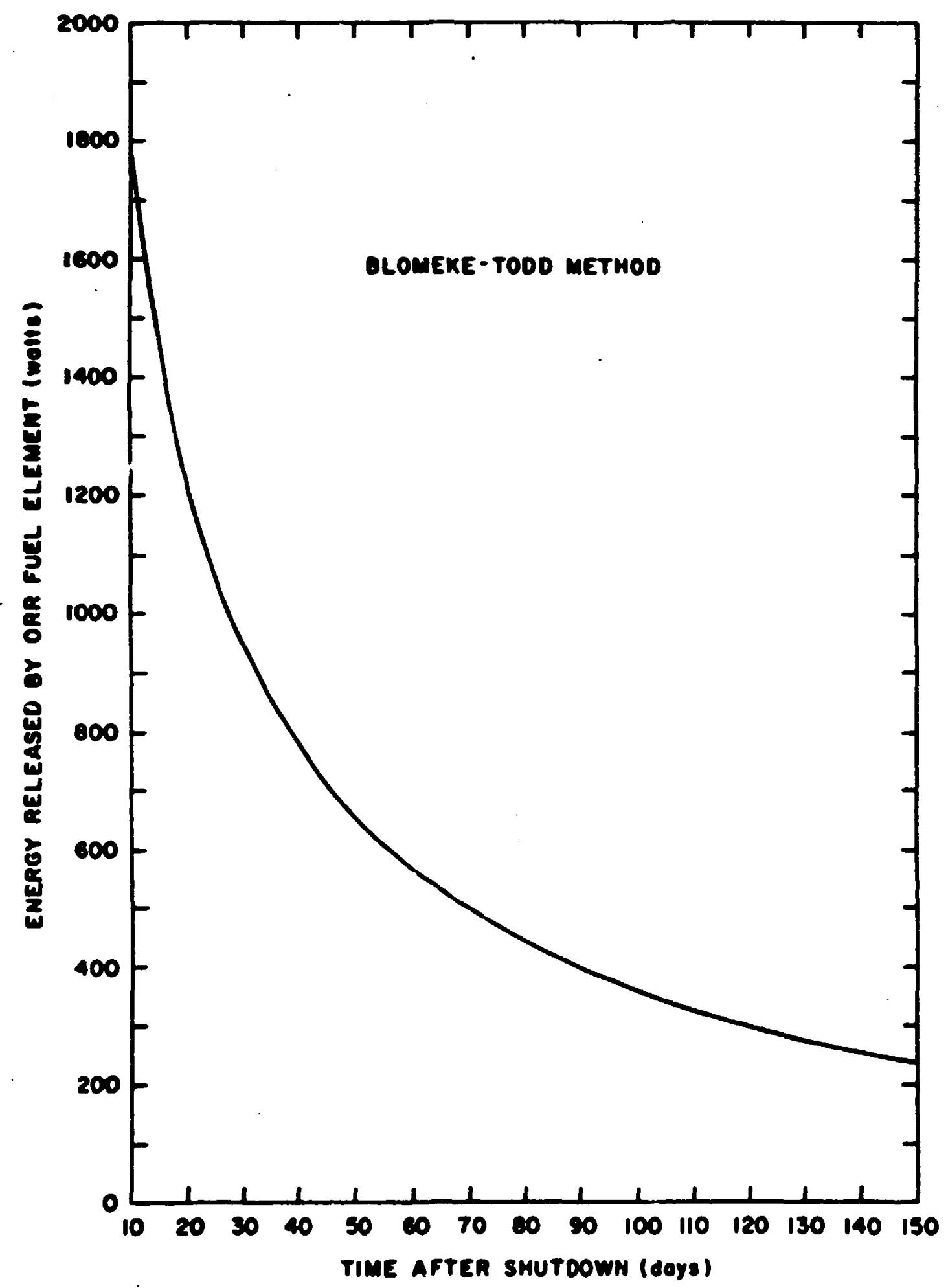

P1g. 5. Rnergy released by one ORR fuel elewent as a function of cooling tine after reactor shutdown (Blomeke-Todd method). 
OANL DW6. 77-15614

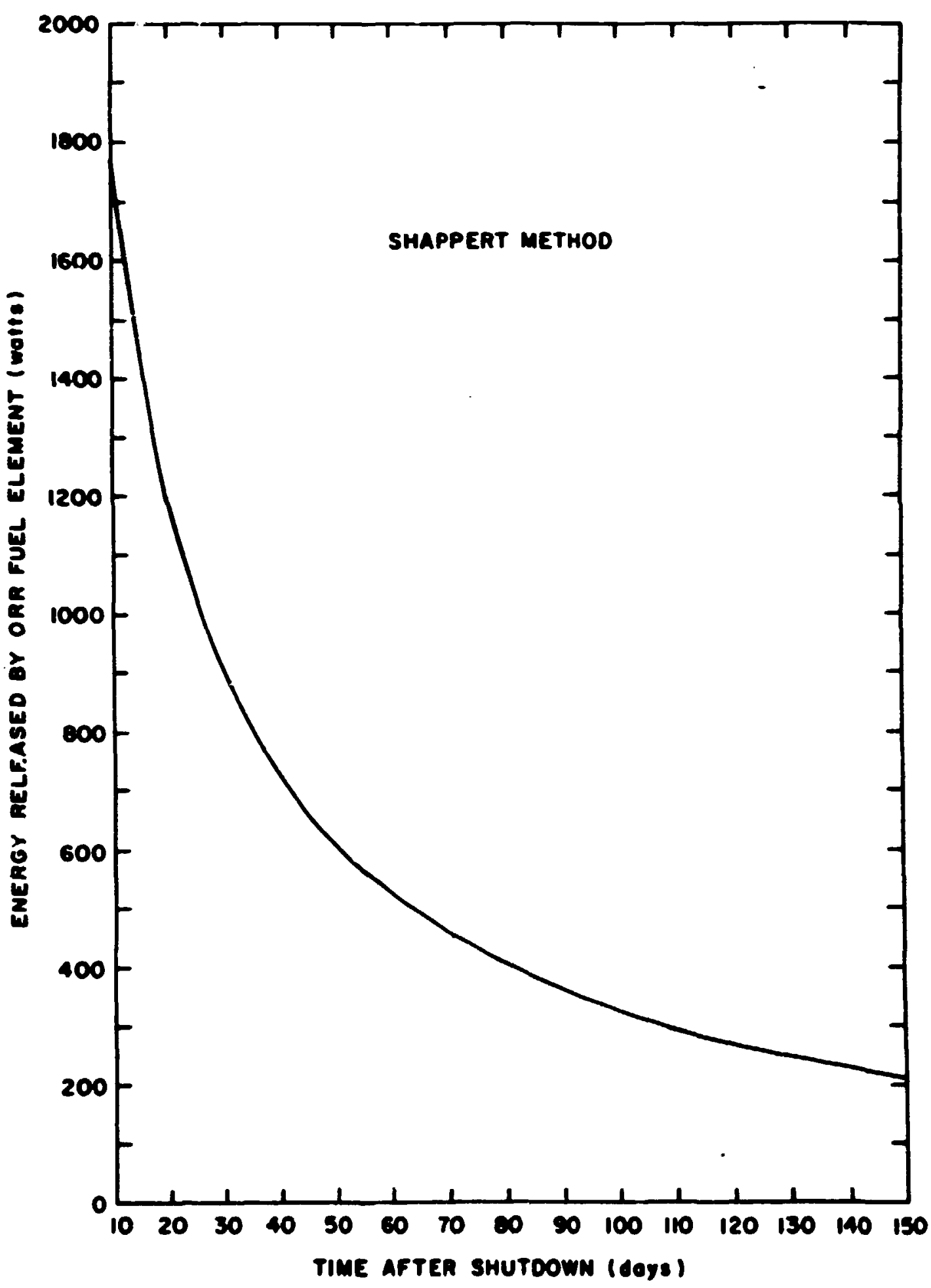

P1g. 6. Energy released by one ORR fuel element as a function of cooling time after reactor shutdown (Shappert method). 
ONML Dwa 77-15S13

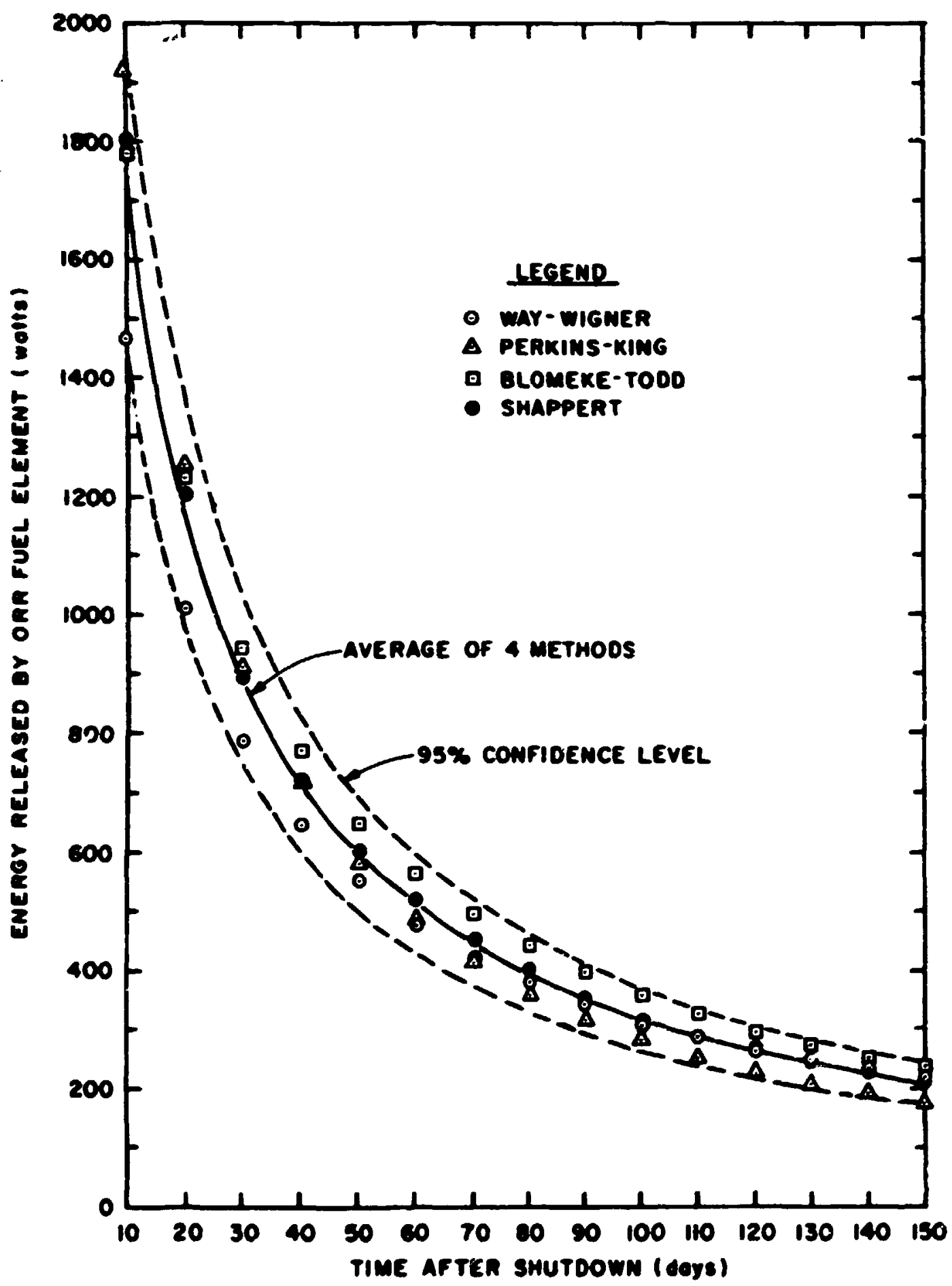

P1g. 7. Comparison of the four nethods used to deterntne the energy released by one ORR fuel element as a function of closing tive after reactor shutdorn following one hundred days of operation. 
TABLE 1

Energy Released by One ORs Fued Elerent as a Function of Cooling Time Aftcr Reactor Shutdom from 100 Daya of Reactor Cperation

\begin{tabular}{|c|c|c|c|c|c|c|}
\hline \multirow[b]{2}{*}{$\begin{array}{l}\text { Oollng Ilue } \\
\text { (DaYs) }\end{array}$} & \multirow[b]{2}{*}{ Way-W1aner } & \multirow[b]{2}{*}{ Perk1.ns $-X 17.8$} & \multicolumn{2}{|c|}{ 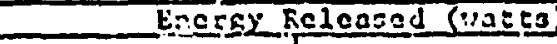 } & \multirow[b]{2}{*}{ Average } & \multirow[b]{2}{*}{$\begin{array}{c}\text { Erose Rer } \\
\text { fros i3 }\end{array}$} \\
\hline & & & Bloweke-Todd & Shappert & & \\
\hline 10 & 2466 & $2: 22$ & 2784 & 1600 & 2743 & 1743 \\
\hline 20 & 1009 & 1250 & 2230 & 1200 & 1172 & 1171 \\
\hline 30 & 785 & 910 & $\$ 43$ & 893 & 093 & 321 \\
\hline 40 & 646 & 715 & 771 & 714 & 712 & $7: 5$ \\
\hline 50 & 550 & 582 & 649 & 601 & 596 & 537 \\
\hline 60 & 479 & 491 & 563 & 518 & 513 & 512 \\
\hline 70 & 424 & 420 & 453 & 453 & 1,48 & $4: 3$ \\
\hline 80 & 380 & 361 & 446 & 402 & 397 & 338 \\
\hline 90 & 344 & 313 & 398 & 354 & 354 & 358 \\
\hline 100 & 314 & 282 & 300 & 321 & 329 & 325 \\
\hline 110 & 289 & 255 & 324 & 289 & 259 & 255 \\
\hline 120 & 267 & 231 & 296 & 269 & 265 & 271 \\
\hline 130 & 248 & 209 & 272 & 246 & 244 & 24,3 \\
\hline 140 & 232 & 192 & 252 & 225 & 225 & 228 \\
\hline 150 & 217 & 276 & 234 & 210 & 203 & 220 \\
\hline
\end{tabular}




\section{REFERERCES}

(1) K. Way and E. P. Higner, Phys. Rev., 73:1318 (1948).

(2) S. Clesstone and A. Sesonske, Nuclear Reactor Engineering, Pp. 98100, D. van Nostrand (1963).

(3) J. F. Perkins and R. H. King, Nuclear Scl. ard Eng., 3:726 (1958).

(4) B. P. Blizard and L. S. Abbot (eds), Rezctor Handbook, Volume 3, Part B, Shielding, Pp. 27-31, Interscience (1962).

(5) A. G. Horthing and J. Geffuer, Trentment of Experimental Data, P. 6, Hiley (1960).

(6) J. O. Blomeke and M. F. Todd, Uranium-235 Flssion Product Production as a Function of Thermal Neutron Flux, Irxadiation Time, and Decay Time. 1. Atoaic Concentrations and Gross Totals, P. 357, ORVL-2127, Part 1, Volume 2 (1957).

(7) 2. B. Shappert, Cask Designers Gulde - A Guide for the Design, Pabrication, and Operation of Shipping Casks for Nuclear Applications, PP. 125-129, ORNL-NSIC-68 (1970). 


\section{Addendun}

At full operation, approximately seven elewents per wonth are declared spent at the ORR. This seans that after a aininen of 150-days decay, there are, on the average, seven elements with 150-days decay, seven elements with 180-days decay, and three elenents with 210-days decay. This gives an overall average decay tive of 170-days decay per elenent. This anounts to an average heat generation rate of $180 \pm 30 \mathrm{~W}$ per elenent. Taking the conservative approach and using the upper linit, there will be no ere than $210 \mathrm{~W}$ genertited per elewent on a shipwent of seventeen spent elements. The attached graph shows the decay period of interest. Rurther, the fuel elements are not left in the reactor for 100 consecutive days but in reality are cycled in and out of the reactor during a sir-conth period - a fact which adds to the conservation of this analyais. 


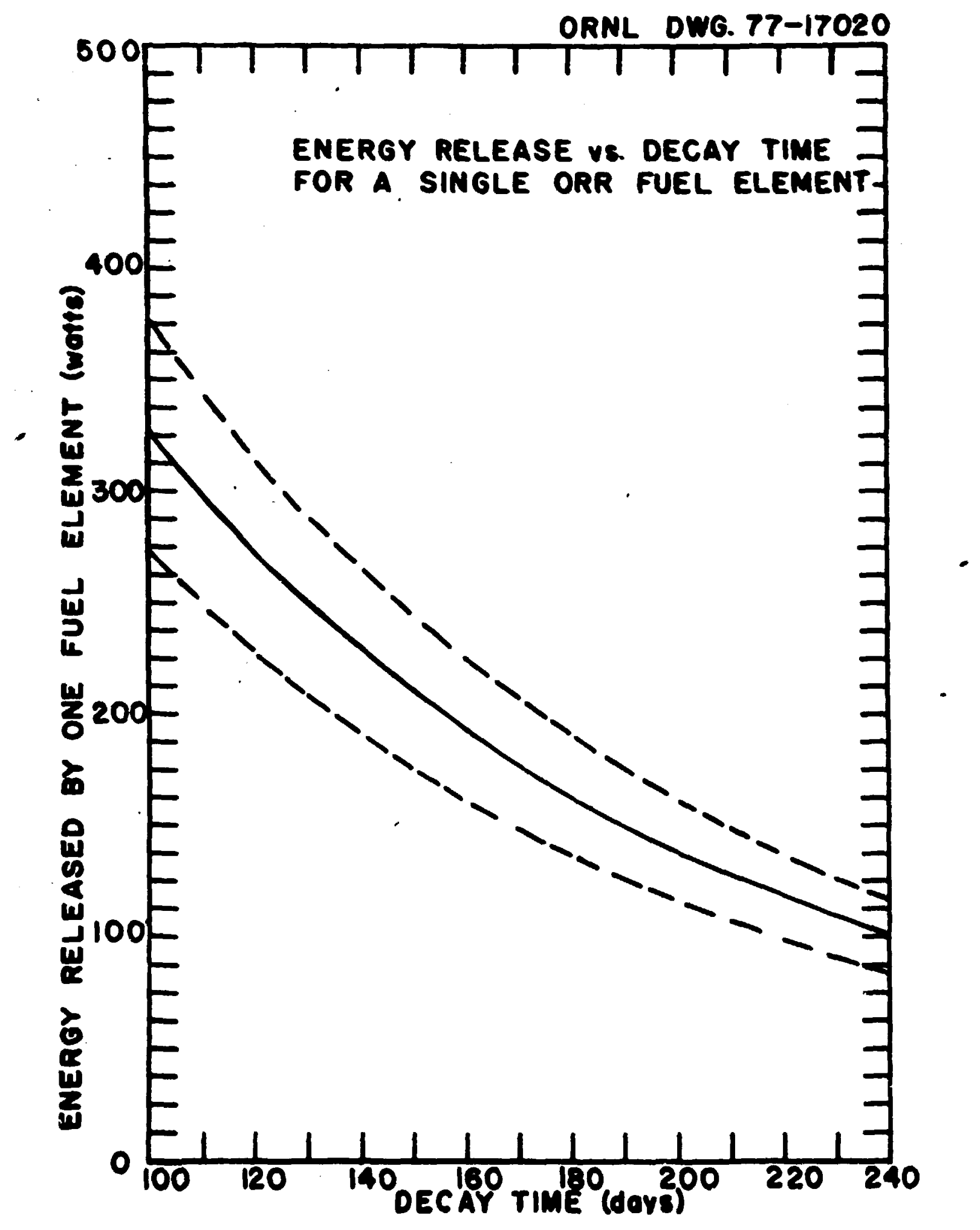

718. 8. Energy release ve decay time for a single ORR fuel element. 


\section{PUERTO RICO NUCLEAR CENTER}

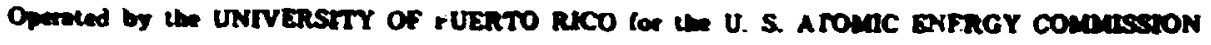

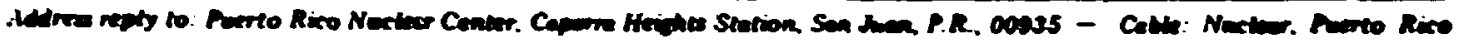

Septen:er 20, 1974

Mr. Josegh A. Lenhard, Directser

Research and Teshatcal Supgort Divisior.

Oak Ridge Operations Jeflis:

U. S. Atonic inero camissiot:

P.O. Bax $\Xi$

ak Kidge, Tennessee $37 \leqslant 30$

Dear Mr. Tenberd:

The followiag information on the irrediated fuel eienents stored in the FuC reactor oool is provided in response to your cacle laquiry of segtenber 9, 19?4.

Inclosured is a 11s: of fuel assemblies ldentifylng the fuel elements and the total energy generated by each in megawatt-days. We can ast state the power generated per element since, durling their sperating histery, each element ins operated in sereral locatisas within the sore in whis the pover generation rates were different. The average power sutput per elemeat was 33.3 kilowatts. This infaration was sitained from the iliel burn-up jata in the tuel element operating history ledger.

As seed fram the list of fuel assemblies, the last grolip of fuel alements came out of the care on March 12, 1972. They have been "saoling" dam slace then far a cotal of $3-1 / 2$ years. All vther elements have longer decay pertods.

Assigning the highest peak t: average, $\% /$, asutr an $f 1$ ux ratio In the arre to sach elsment (in order to be conservative $\rho 2 r$ calculation purpases) xeasured as 1.8 in the one negawatt Mar typa sore (IRHC 57) we o stain a maximun hest jeneration rate of 50 k1lowatts per elewent. Using cecay heat curres for lrradisted elements (infinite reactsr joerating time; U.S. Reactor crotainment Technolog, Vol. I, 5.127) ve ottain that after a miniman of 3-2/2 jear decer the pover generation $1: 0.06 \%$ of the ariginal operating Farer, that 1s, 36 intt3. Mis number is well below the 210 ratts per flement lintt of the FIIR cask.

Sincerely yours,

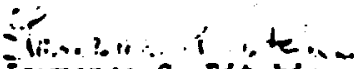
Iamrence 3 . Ritichle

Directsr

$\mathrm{LSR} / \mathrm{n}$ =

sncls. 
IRPADIATED FUEL ASSERLIES

Fuel Asse-bly to.

$D C-1$

PS-3

PS-4

PS-5

PP-5

$P C-6$

$P P-6$

PS-7

PC-7

PP-7

PS-8

PS-9

PC-10

PS-11

PS-12

PC- 12

PS-15

PS-18

PS-21

PS-24

PS-29

PS-30

PS-33

PS-35

PS-39

PS -40

PS-43

PS- 44

PS-47

PS-55

PS-1

PP-1

PS-2

$P C-2$

$P P-2$

PC-3

PP-3

PCA

$P P-4$

$P C-5$

PS-6

PC-8.

PS-10

PP-10

PC-11

Last Dey in Core

MnO

3-12-71

339.730

3-12-71

725.039

3-12-71

241.911

$3-12-71$

541.642

$3-12-71$

343.812

$3-12-71$

415.310

3-12-71

104.659

3-12-71

266.723

3-12-71

703.577

3-12-71

104.659

3-12-71

226.103

3-12-71

581.956

3-12-71

62.895

3-12-71

213.496

3-12-71

722.166

3-12-71

30.326

3-12-71

3-12-71

3-12-71

3-12-71

3-12-71

3-12-71

3-12-71

3-12-71

3-12-71

3-12-71

3-12-71

- 3-12-71

3-12-71

3-12-71

$12-20-66$

425.771

541.322

182.44:

473.839

154.659

104.659

104.659

703.577

703.577

703.577

39.504

39.504

- 778.545

30.602

303.922

8-13-69

118.402

399.926

526.775

594.778

594.645

529.339

603.507

381.902

97.139

551.202

327.819

248.702

231.752

180.819

45

$-1-70$

$4-23-70$

180.819 


$\begin{array}{lc} & \text { Fuel Asseably No. } \\ 46 & \text { PP-11 } \\ 47 & \text { PS-14 } \\ 48 & \text { PS-16 } \\ 49 & \text { PS-17 } \\ 50 & \text { PS-19 } \\ 51 & \text { PS-20 } \\ 52 & \text { PS-22 } \\ 53 & \text { PS-23 } \\ 54 & \text { PS-25 } \\ 55 & \text { PS-26 } \\ 56 & \text { PS-31 } \\ 57 & \text { PS-32 } \\ 58 & \text { PS-34 } \\ 59 & \text { PS-36 } \\ 60 & \text { PS-37 } \\ 61 & \text { PS-38 } \\ 62 & \text { PS-42 } \\ 63 & \text { PS } 45 \\ 64 & \text { PS-49 } \\ 65 & \text { PS-51 } \\ 66 & \text { PS-52 }\end{array}$

Last Day in Core

Mo

12-9-63

66.912

$12-1-69$

12-1-69

12-10-69

3-26-69

3-13-67

3-26-69

12-1-69

8-12-69

12-10-69

4-4-67

9-30-65

11-21-68

3-26-69

3-26-69

3-26-69

8-27-68

3-26-69

$12-1-69$

2-27-67

9-1-70

122.848

396.353

297.760

563.188

304.346

547.290

599.685

97.405

124.419

95.777

95.804

170.523

526.775

526.455

551.766

253.929

624.586

415.424

251.660

676.185

Note: Assemblies designated PC are control assemblies. Assemblies designated PS are standard assenblies. Assemblies designated PP are partiai assemblies. 
$\therefore$

-

$\therefore$

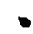

-

-

TEST RESULTS AND MODEL

Appendix $E$

$+$ 
ORNL Impact Test Description 74-2:

HFIR Cask Top Impact

\section{Purpose}

The test outline below will be conducted to establish the response of the BFIR cask (DOT Speciai Pormit 5507) to top impact (with the axis of cask vertical). It is proposed that the cask be modified as shown on the attached sketch (FIg. E.1). The data taken will be used to establish the response of the modified cask in the 30 -ft free-fall accident specified in the regulations. I of particular importance is the ability of the plug studs to withstand the dynamic forces while alntaining the primary seal. Calibration data for the ORKL peak recording acceleroneter will be taken incidental to the tests.

\section{Model Description}

The test model is a 2.35-to-1 scale model of one of the four 4-in. schedule 80 pipes added to the cask pipe fin structure (see Fig. E.1). The model is illustratel in Fig. E.2. Five models and one mounting plate were fabricatej and insperted in accordance with this drawing.

\section{Test Procedure}

The variable-welg, ht drop hammer will be loaded with $436 \mathrm{lb}$. This is the 2.3-to-1 scale equivalent of one-fourth the weight of the loaded HFIR cask. The 3000-K load cell will be secured to the impact surface. The instrumentation secup shown schematically in Fig. E.3 will be used to record the force applied to the model with respect to time. The initial length, outside diameter, and wall thickness w111 be measured and recorded on the attached data sheets. The nodel will be centered on the load cell and impacted with the free-falling weight from $30 \mathrm{ft}$. The final deformed length will be measured and recorded on the data sheets. Callbration da:a for the ORsil recording accelerometer will be taken per test description 73-1 and recorded on the attached supplemental data sheets. 


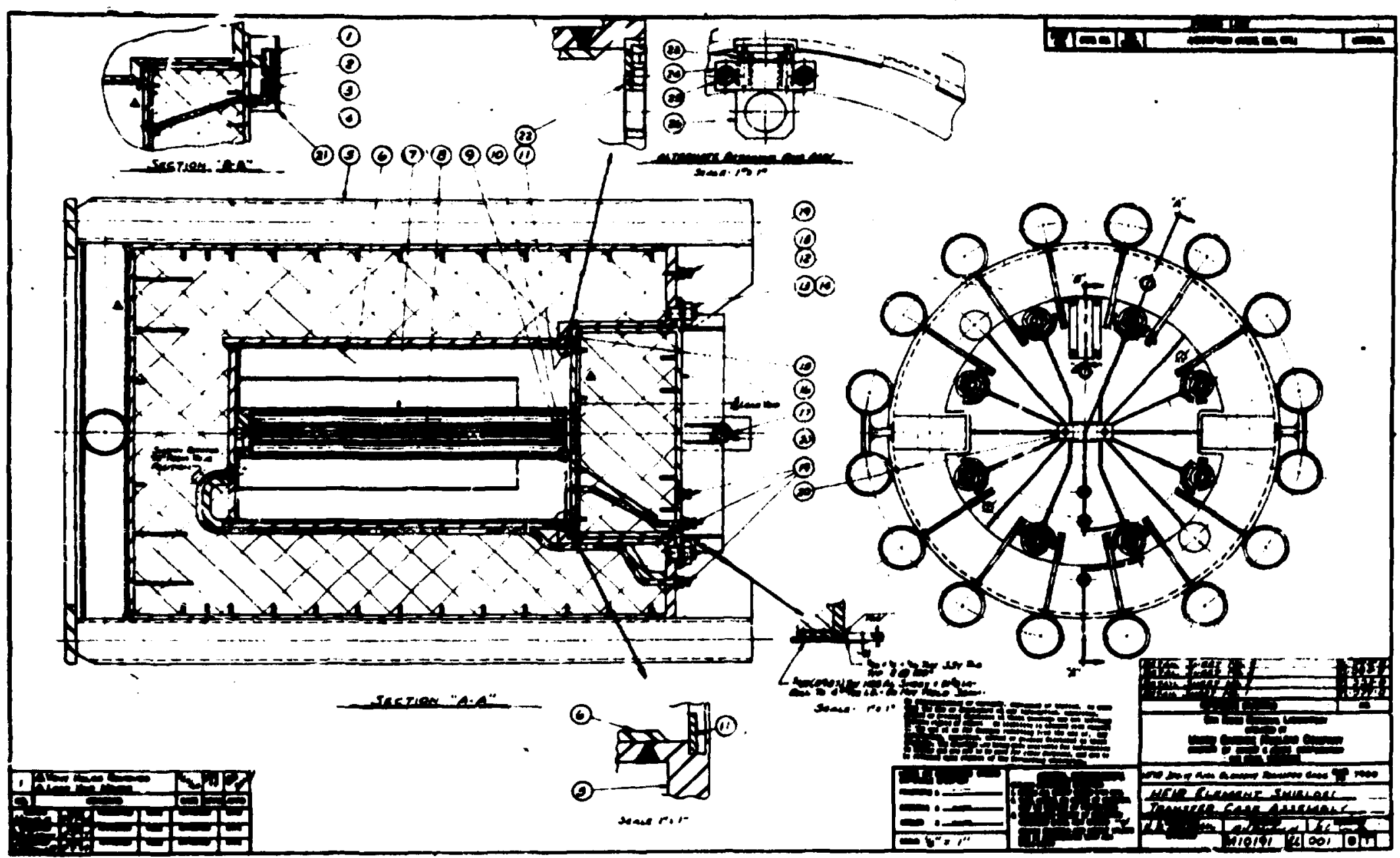

F1g. E.1. HFIR spent-fuel sh1pping cask. 


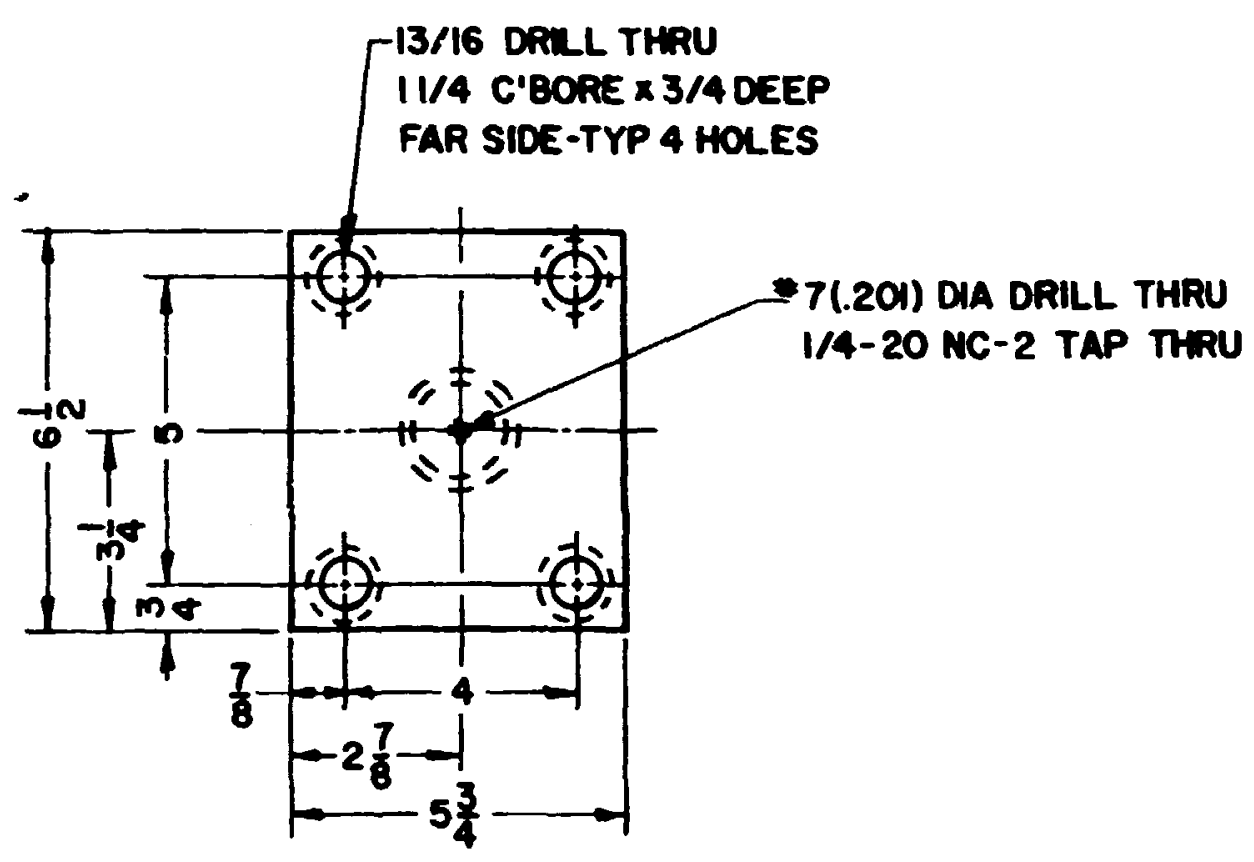

I1/2 SCH 40 PIPE

TYPE 304-L SST ASTM A376-ORNL STORES NO. 07-231-3145

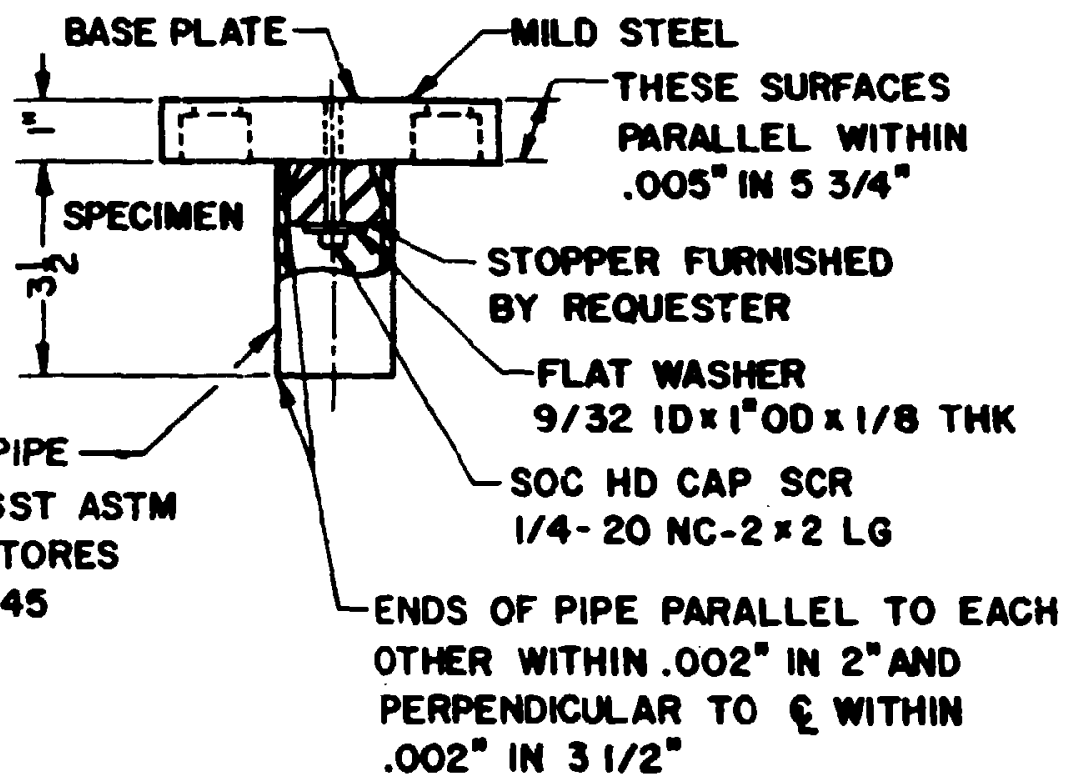

F18. E.2. HIIR impact test model. 


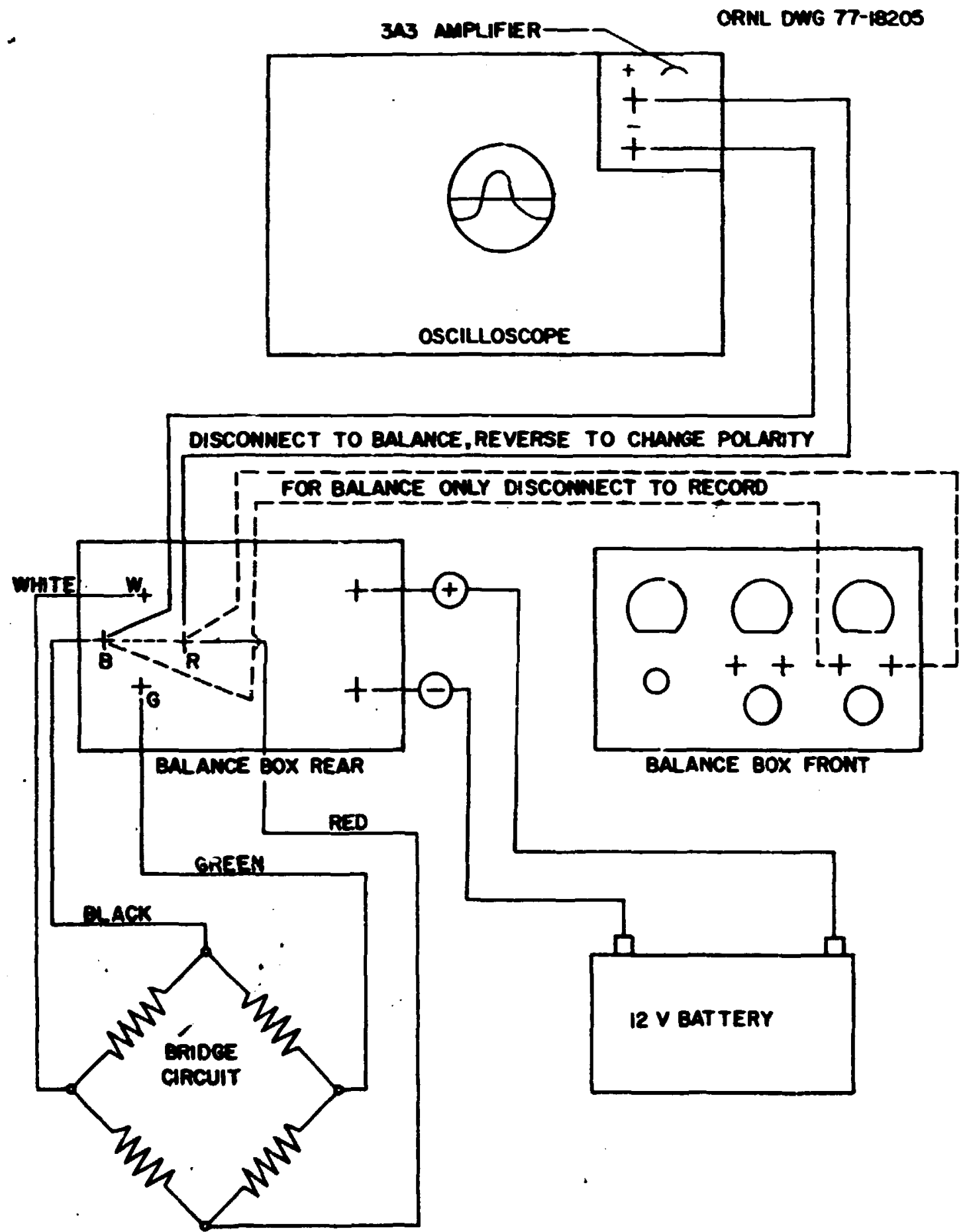

P1g. E.3. Typical load cell hook-up. 

Po Name
Divisien
locaticen
N. C. Bradley
R. E. Harris, 0RO
L. B. Shappert
L. V. Wilson
R. V. Mccord
R. W. Schaich

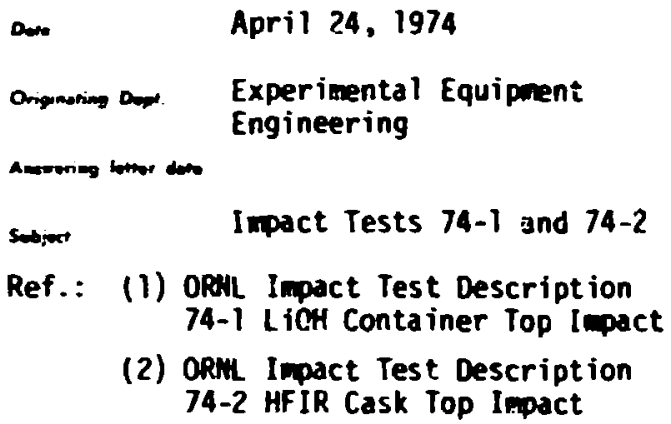

Ref.: (1) ORAL Impact Test Description 74-1 LiCH Conta iner Top Imact

(2) ORit Inpact Test Description 74-2 HFIR Cask Top Impact

On April 18, 1974, N. C. Bradley and I performed the subject impact tests. Five models per 74-1 and three models per 74-2 were tested. The tests mere witnessed by Raymond E. Harris of AEC-ORn. The test results are sumarized below in Tables I and II.

Table 1. Summary of Test 74-1

\begin{tabular}{ccccc}
\hline $\begin{array}{c}\text { Specimen } \\
\text { Humber }\end{array}$ & $\begin{array}{c}\text { Drep } \\
\text { Height } \\
\text { in. }\end{array}$ & $\begin{array}{c}\text { Weight } \\
\text { Oropped } \\
\text { 1b }\end{array}$ & $\begin{array}{c}\text { Final } \\
\text { Defonmation } \\
\text { in. }\end{array}$ & $\begin{array}{c}\text { Maximum } \\
\text { Acceleration } \\
\times \text { g }\end{array}$ \\
\hline $74-1-1$ & 360 & 125 & 2.53 & 190 \\
$74-1-2$ & 360 & 125 & 2.36 & 200 \\
$74-1-3$ & 360 & 125 & 2.26 & 200 \\
$74-7-4$ & 360 & 125 & 2.53 & 200 \\
$74-1-5$ & 360 & 125 & 2.12 & 210 \\
\hline
\end{tabular}

Table II. Summary of Test 74-2

\begin{tabular}{ccccc}
\hline $\begin{array}{c}\text { Specimen } \\
\text { Nuntber }\end{array}$ & $\begin{array}{c}\text { Drop } \\
\text { Height } \\
\text { in. }\end{array}$ & $\begin{array}{c}\text { Weight } \\
\text { Dropped } \\
\text { l6 }\end{array}$ & $\begin{array}{c}\text { Final } \\
\text { Deformation } \\
\text { in. }\end{array}$ & $\begin{array}{c}\text { Maximum } \\
\text { Acceleration } \\
\times 9\end{array}$ \\
\hline $74-2-1$ & 360 & 425 & 2.34 &.$-^{3}$ \\
$74-2-2$ & 360 & 237 & 1.79 & 200 \\
$74-2-3$ & 360 & 342 & 1.77 & 200 \\
\hline
\end{tabular}

Orop height $\pm 1 / 2$ in.

2 Includes wt. of specimen mounting hardware.

${ }^{3}$ Acceleration-time record not usable due to use of excessive weight. 
Test description 74-1 was followed rather closely. (There were no sifnicicant deviation.) Specimens nubered 74-1-1, 74-1-2, and 74-1-4 failed by buckling at about their aid-point. Srecimens 74-1-3 and 74-1-5 failed by the we joining the two angles splitting. It apcears that this was because the wids wre not comlete penetration. A more knowledge able opinion will be sought to verify this.

There were significant deviations from description 74-2. The load cell data system described ws not used. Instead, the system described in 74-? was used since it set set $\Leftrightarrow$, working, and as applicable. After specimen muber 74-2-1 was dropped, it ws obvious that force required for failure ms significantly less than anticipated and tiat the use of four extended pipes for the HFIR ws ipactical. It was also probable that the rubber used to secure the model to mounting plate had contributed significantly to the energy absorption. Drop wight ws adjusted first to simulate eight pipe extension: for the cask and then to simulate six. After this, the test ws suspended and the two untested spacinens saved for possibie testing at a later date. The ista taken will be exalusted to determine if six or elght are practical for the full-size cask. The failure mode for all the ir specians ms lober buckling.

The tested specimens are now being photographed.

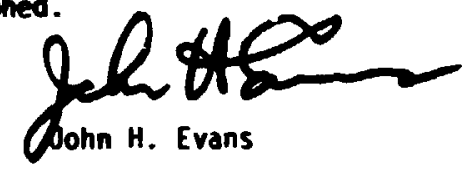

JHE:gl 
Append 1x $F$

COMPUTER DERIVATIONS

1010 CASK

1005 CASK

1015 CASK 


\section{Progres 2005 CASK Derivation of Bquations}

When a cylindrical cask fabricated from a howgeneous anterial impects on Its side, the deformation can be approximated as shown in P18. F.1. The volume $\nabla$ of meterial displaced, shown shaded in Fig. F.1, is expressed as

$$
\begin{aligned}
& V=L R^{2} / 2(2 \theta-\sin 2 \theta) . \\
& V=R^{2} L(\theta-\sin \theta \cos \theta) .
\end{aligned}
$$

For this derivation it is assumed that the cask is fabricated from an Ideal plastic material; that is, a waterial which has atress-strain relationship wich can be represented by a horisontal 1ine. For such a saterial, the product of the specific energy $S$ (the quantity of energy required to displace a unit volume of material) and the volume displaced is equal to the absorbed energy $U$, as below:

$$
U=S V=S R^{2} L(\theta-\sin \theta \cos \theta)
$$

This equation can be solved by trial and error by assuming values of $\theta$ and calculating unt1l

$$
\mathbf{U}=\mathbf{W h} \text {, }
$$

where $W$ is the cas'. weight and $h$ is the drop height.

The deflection $X$ is

$$
X=R(1-\cos \theta) \text {. }
$$

The area $A$ at the surface is

$$
A=2 L R \sin \theta .
$$





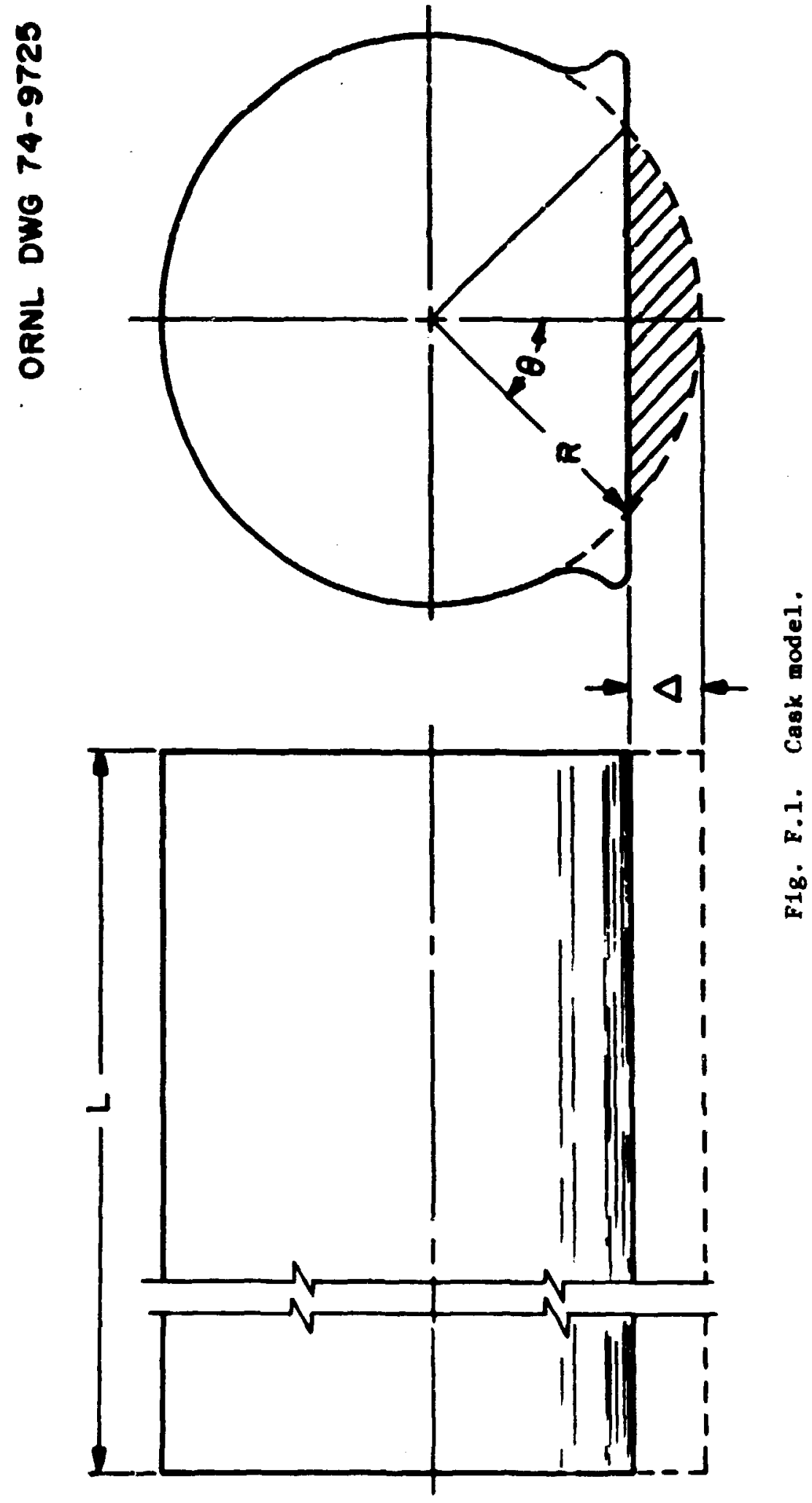


It follows that the force $F$ is

$$
\mathbf{F}=\mathbf{S A},
$$

and the acceleration $a$ is

$$
=\mathrm{F} / \mathrm{M}=\mathrm{Fg} / \mathrm{W}
$$

A computer prozran can be written to solve these equations for increasing values of $\theta$ until the deformation is suffictent for $U$ to equal the cask's potential energy Wh. In this fashion an acceleration deflection and energy history of the impact can be calculated. Also velocity $V$ can be computed from the kinetic energy relationship:

$$
\mathbf{U}=\Delta \mathbf{K E},
$$

and the lapsed time from the relationship is

$$
d t=d v / a \text {. }
$$




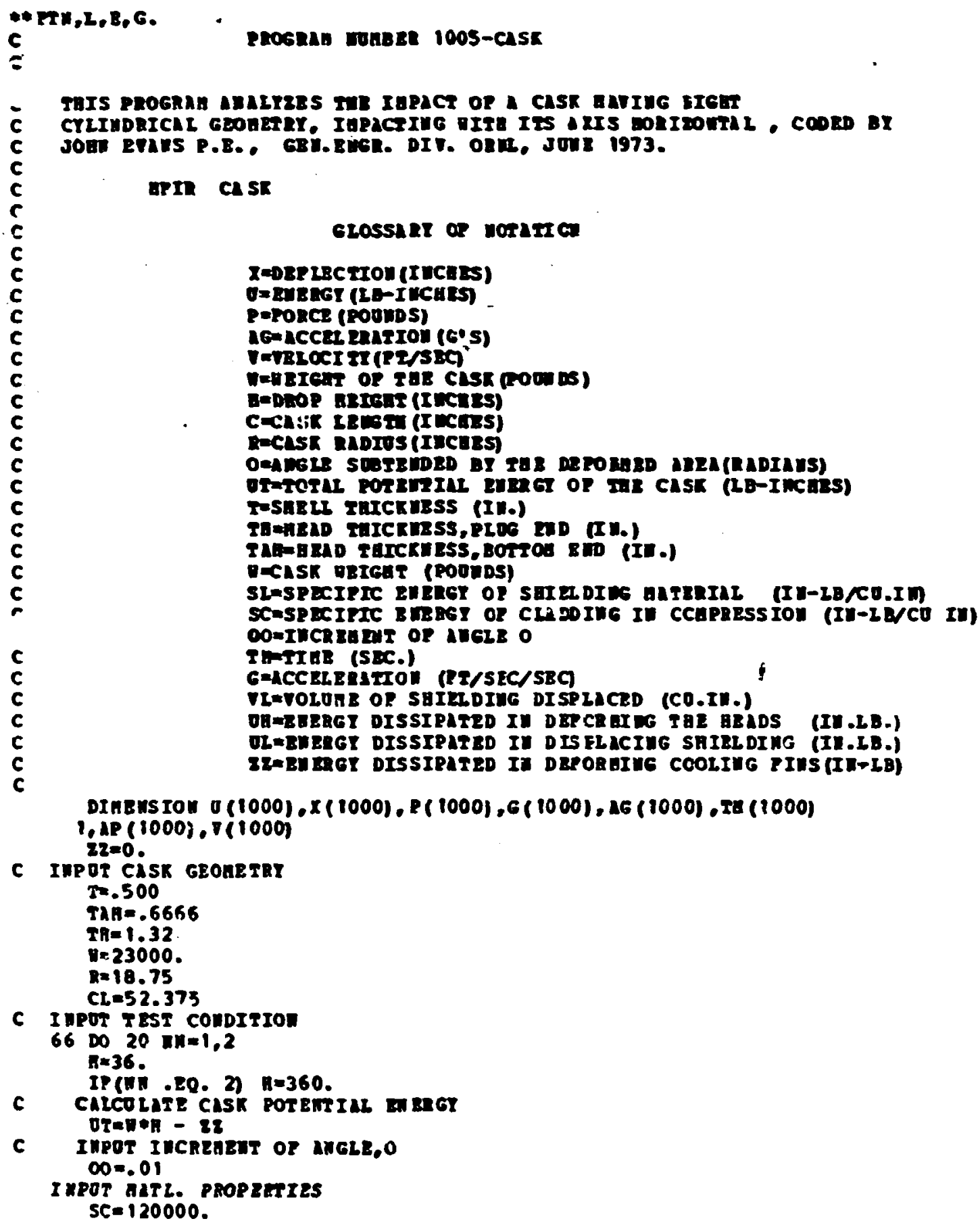


Do $326 \pi C=1,2$

$S L=6000$.

IF (KC.EQ - 2) SL $=14000$

ZERO SOBSCATPTED TARI LOLES

Do $I I=1,1000$

$x(n)=0.0$

$0(I)=0.0$

$I I(I)=0.0$

$G(I)=0.0$

$P(n)=0$.

$\operatorname{LG}(\mathrm{I})=0.0$

$A P(I)=0.0$

$\nabla(I)=0.0$

1 conrinos

C 8BHO nOUSOBSCA IPTED TARIMALES

$O L=0.0$

$0 \mathrm{~B}=0.0$

DT $=0.0$

$\mathrm{TS}=0.0$

$P 0=0.0$

$77=0.0$

$v 0=0.0$

$P P=0.0$

$\mathbf{X} \times=0.0$

$0=0.0$

$\nabla(1)=\operatorname{SQRT}((64.07 / 12)$.

$\operatorname{Vin}(1)$

DO $2 I=1,1000$

IF(I.2Q. i) 00 TO 21

$0=0+\infty$

soesIu (0)

$\operatorname{SoO}=\operatorname{SIn}(2 . \bullet 0) / 2$.

$\cos =\cos (0)$

C CALCOLATE TOLOAB OF SAIBLDING DISPLACBD

c econtron

$V L=(R * B+C L *(0-500))$

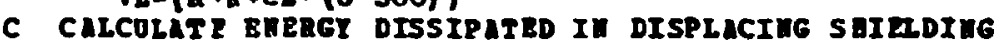

C Equation 2

ULESI*TL

C EQOATIOU 6

$00=0-500$

C EQUATION 12

$\nabla A=(T H+T A R) \bullet R \bullet R \bullet 00$

C Eoontron 13

OH=SC+VH

$A B L=2 \cdot \oplus R * 50 * C L$

10

PORL=ARL HSL

$A B A=2 . \otimes B=S O *(T A+T A B)$

PORA = ARR $\oplus S C$

O (I) $=$ OH $\bullet$ OL

C Conpote defonanton

$x(I)=R *(1 .-C O)$

C COHPOT IPPLIED FORCE

20

39

37

102

$P(T)=$ PORL - PORH

conpute nCCELEAATION

$G(I)=(P(I) * 32.1 / 0$

$\Lambda G(I)=P(I) / 0$ 


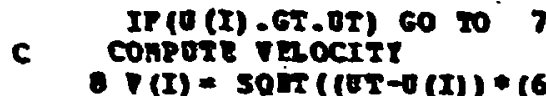

- $\nabla(I) * 30 x(16 \mathrm{~s}-0(\mathrm{I})) *(64.8(4 * 12))$.

conritur

COMPUT2 LAPSED TIRE

vr=0.

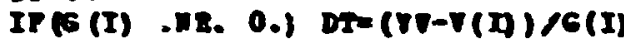

TSETS+DT

117

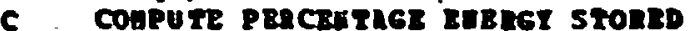

PoD $15 / 02$

21 corrinos

$\Sigma I X=X(I)$

OU⿴囗十 $(I)$

$\operatorname{TV}=7(x)$

$P P=P(I)$

IP(OI).Q2.UI) 0020

151

152

2 conrins.

conrino:

160

161

$J=I-1$

c oureor-18IRE LOOP

DIITE (51. 1009)

MITE (5), 1009)

DRTYE (51, 1002)

DETTE(E) 100a)

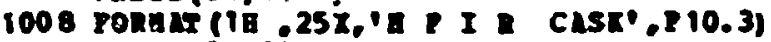

DRTE $(51,1002)$

DRITE $(51,1009)$

DRIPE (51,: 090$)$

DITE $(51,1002)$

Datr E (51,1004)

DEITE $(51,1002)$

DITE $2(51,1005)$

DITE (51.1006)

DRITE (51, 1002)

162

1002 PORnAT (1BO)

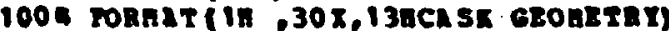

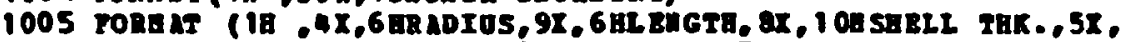

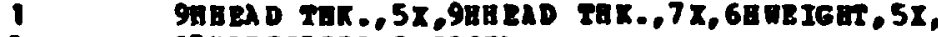

2

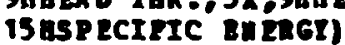

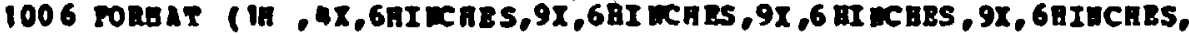

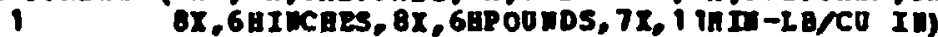

MEITE (51, 1007) R,CL,T, TH,TAB, H.SL

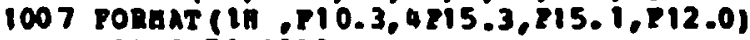

DRTE (51,1002)

URITE (51, 1009)

URT $\mathrm{B}(5), 1009)$

$\operatorname{DETT2}(51,1002)$

URITE (5), 1000)

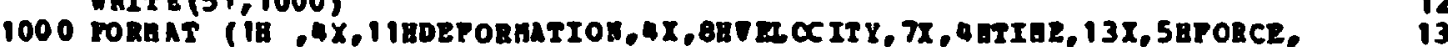
10X,6月ENERG, 5X, 12 UACCELEEAT IOU)

DRITE (5), 100 i)

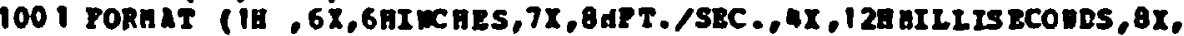

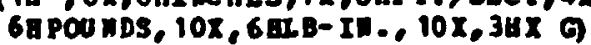

111188

IR ITE (51, 1002$)$

112188

11. 199

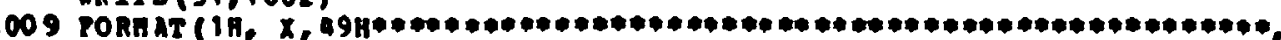

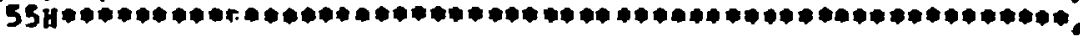



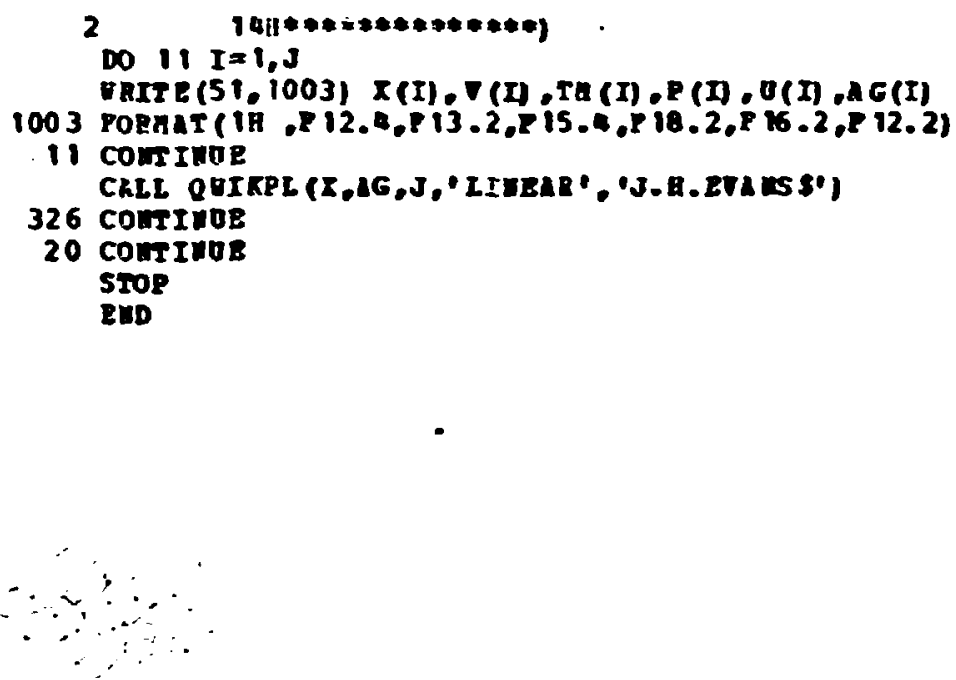


\section{Progran 1015 CASR}

Derivation of Equations for Solution of an Impact with the Cask Bquipped with a Toroldal Energy Absorber

When a cask with a toroldal energy absorber which fails in comression (F18. F.2) impacts an unyielding surface, the deformed surface of the absorber will te as shown in Fig. F.2. For any differential area dA, the applied force $d F$ is

$$
d P=\sigma d A=C R d R d \theta=
$$

where

$$
\sigma=\text { stress at dA. }
$$

There exists an expression such that

$$
a=f(\varepsilon)=f\left(X_{a} / L_{a}\right),
$$

where

$$
\begin{aligned}
\varepsilon & =\text { strain, } \\
X_{a} & =\text { deflection at dA. }
\end{aligned}
$$

It can be written

$$
x=y \operatorname{Tan} \alpha=\operatorname{Tan} \alpha\left(R \cos \theta-R_{0} \cos \phi\right) .
$$

Since

$$
\sigma=f\left[\operatorname{Tan} \alpha\left(R \cos \theta-R_{0} \cos \phi\right) / L_{a}\right],
$$

and

$$
d F=f\left[\operatorname{Tan} a\left(R \cos \theta-R_{0} \cos \phi\right) / L_{a}\right] R d R d^{\theta} .
$$


ORNL DWG 74-11902

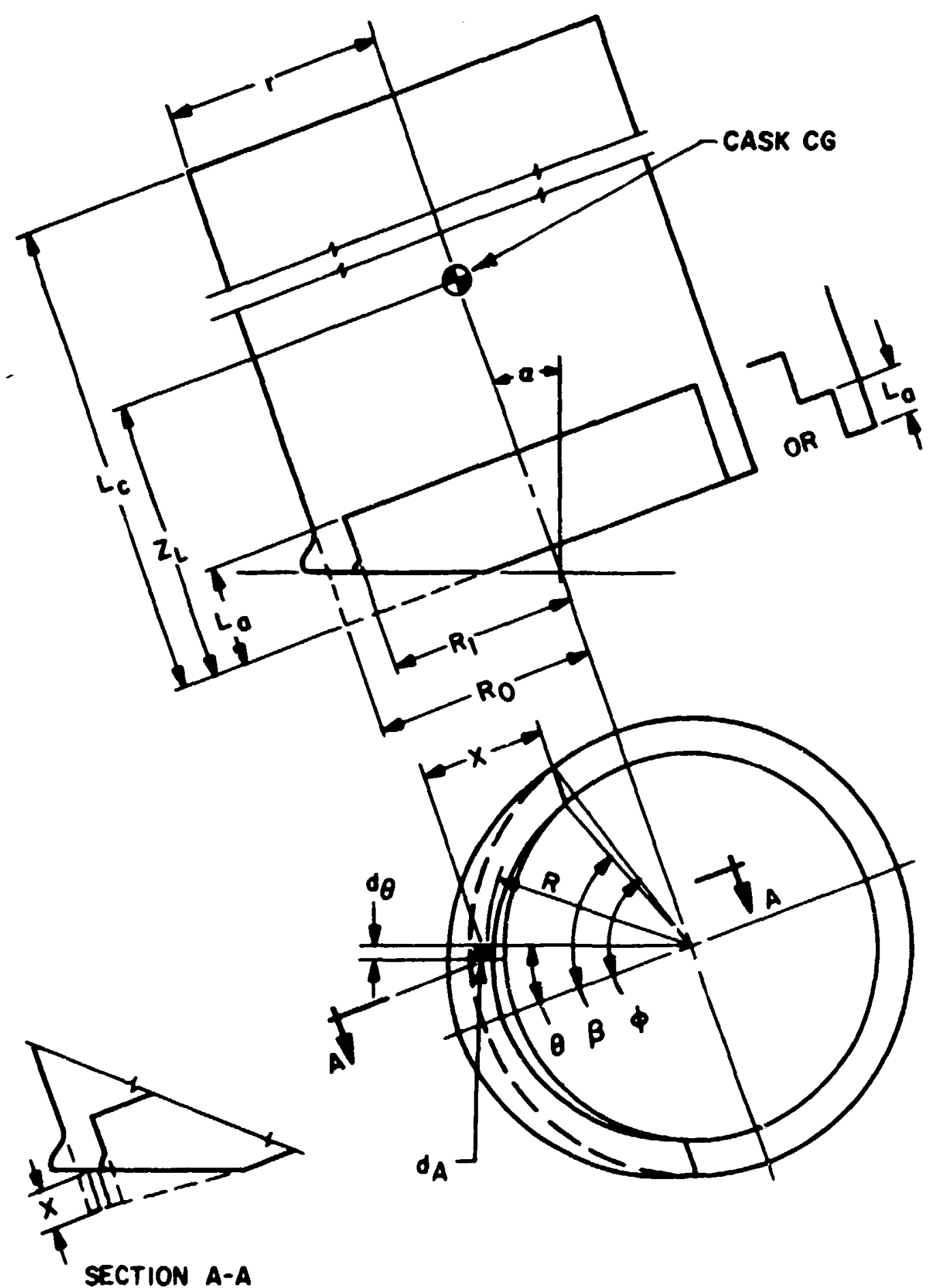

Fig. F.2. Cask m.odel. 
The cotal force $\mathbf{F}$ is

$$
F=\sum_{R=R_{1}}^{R=R_{u}} \sum_{\theta=0}^{\theta=\phi} f\left[\tan a\left(R \cos \theta-R_{0} \cos \phi\right) / L_{a}\right] R d R d^{\theta} .
$$

The differential energy do is

$$
d U=d F X_{a}
$$

Total energy $U$ is

$$
\begin{aligned}
U & =\sum_{R=R_{1}}^{R=R_{0}} \sum_{\theta=0}^{\theta=\phi} \tan a\left(R \cos \theta-R_{0} \cos \phi\right) f \\
& x\left\{\tan a\left[R \cos \theta-R_{0} \cos \phi / L_{a}\right] R d R d \theta\right\} .
\end{aligned}
$$

If these suwwations are effected for increasing values of $\phi$ unt 11 a value of $\phi$ is found such that the energy $U$ equals the cask's potential energy, a force and energy vs deformation history of the Impact can be estimated. Other impact parameters such as acceleration, velocity, etc., are estimated using the basic principles of applied mechanics. The following FORTRAN program effects these sumations and other calculations. 


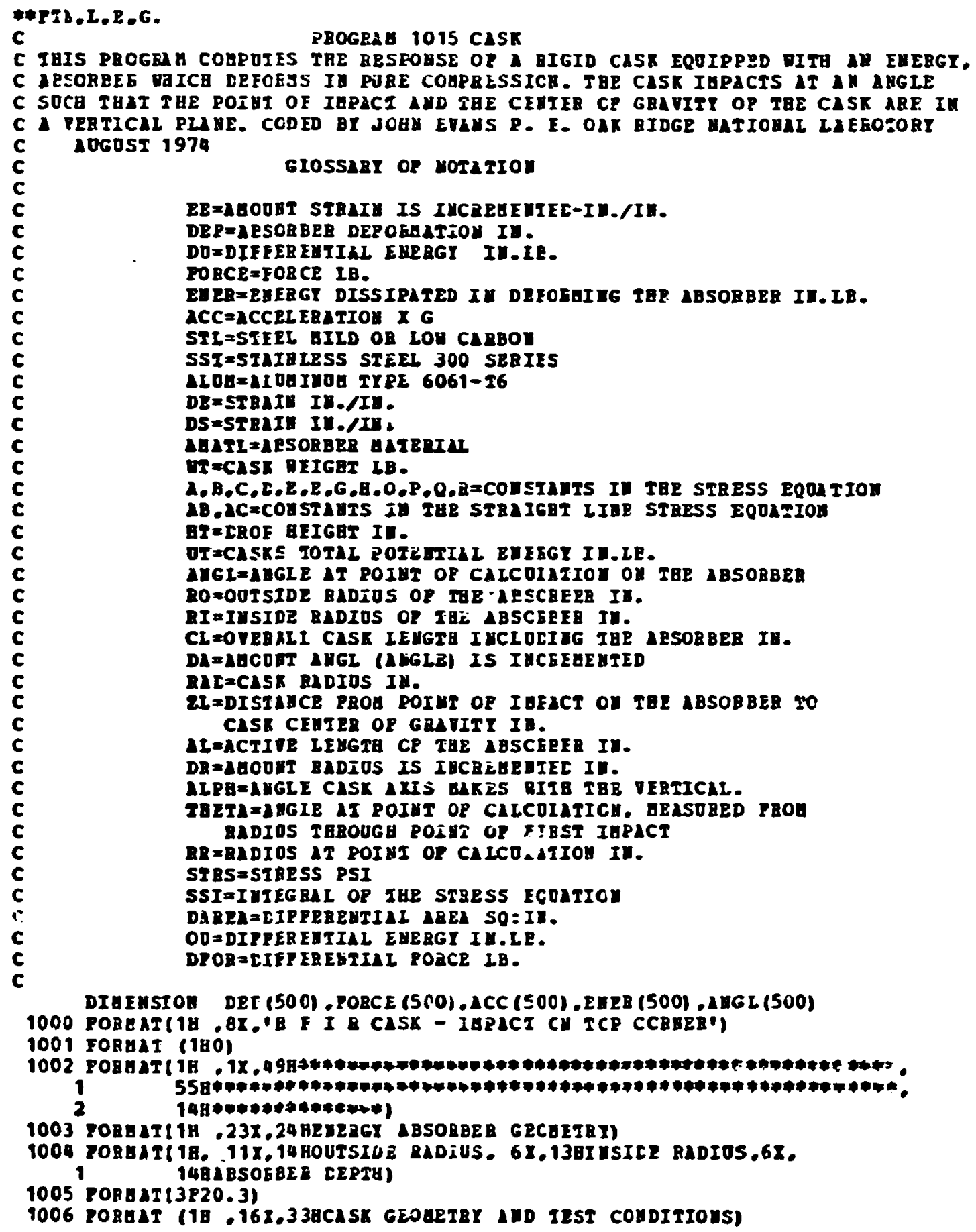




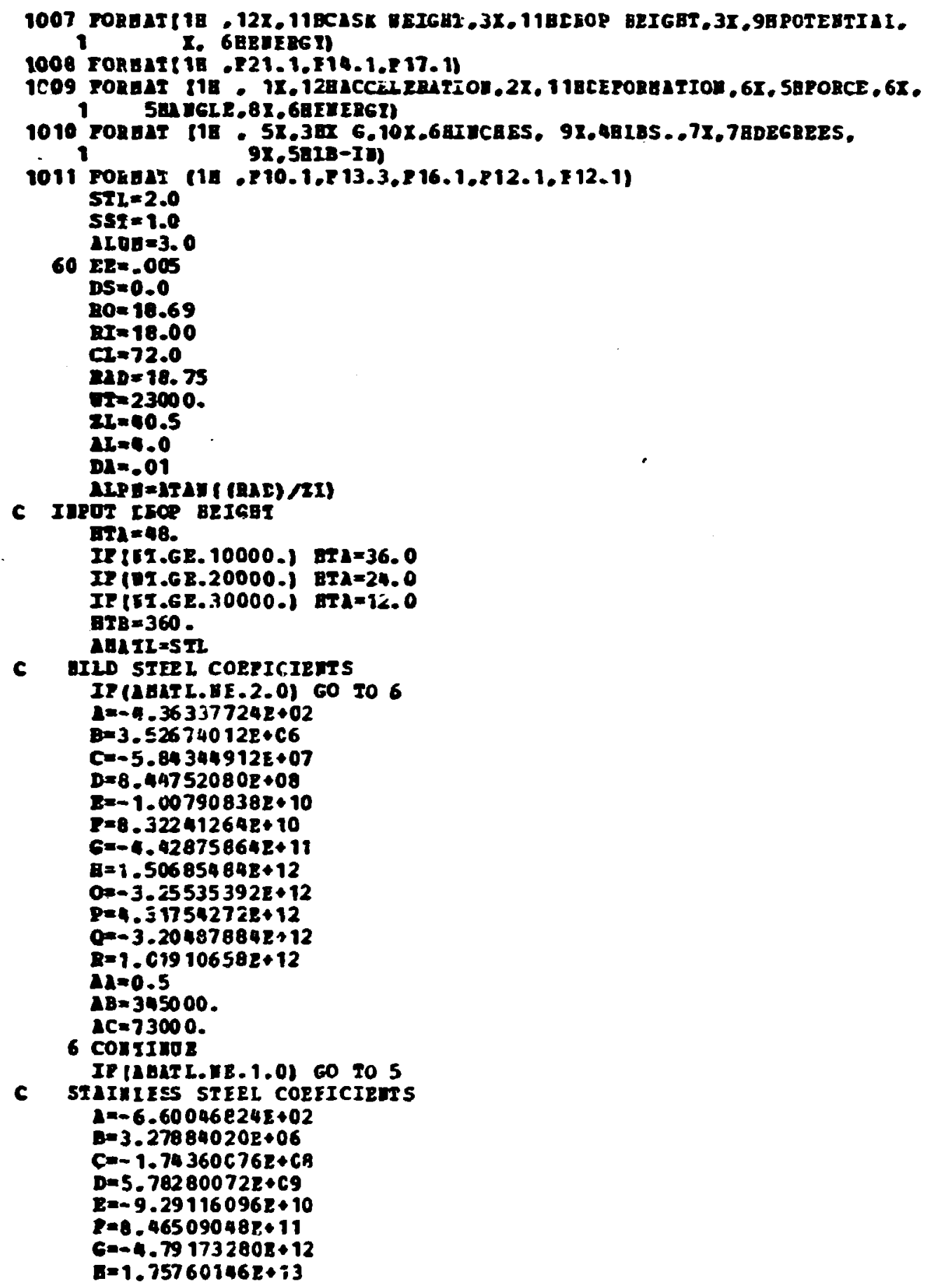




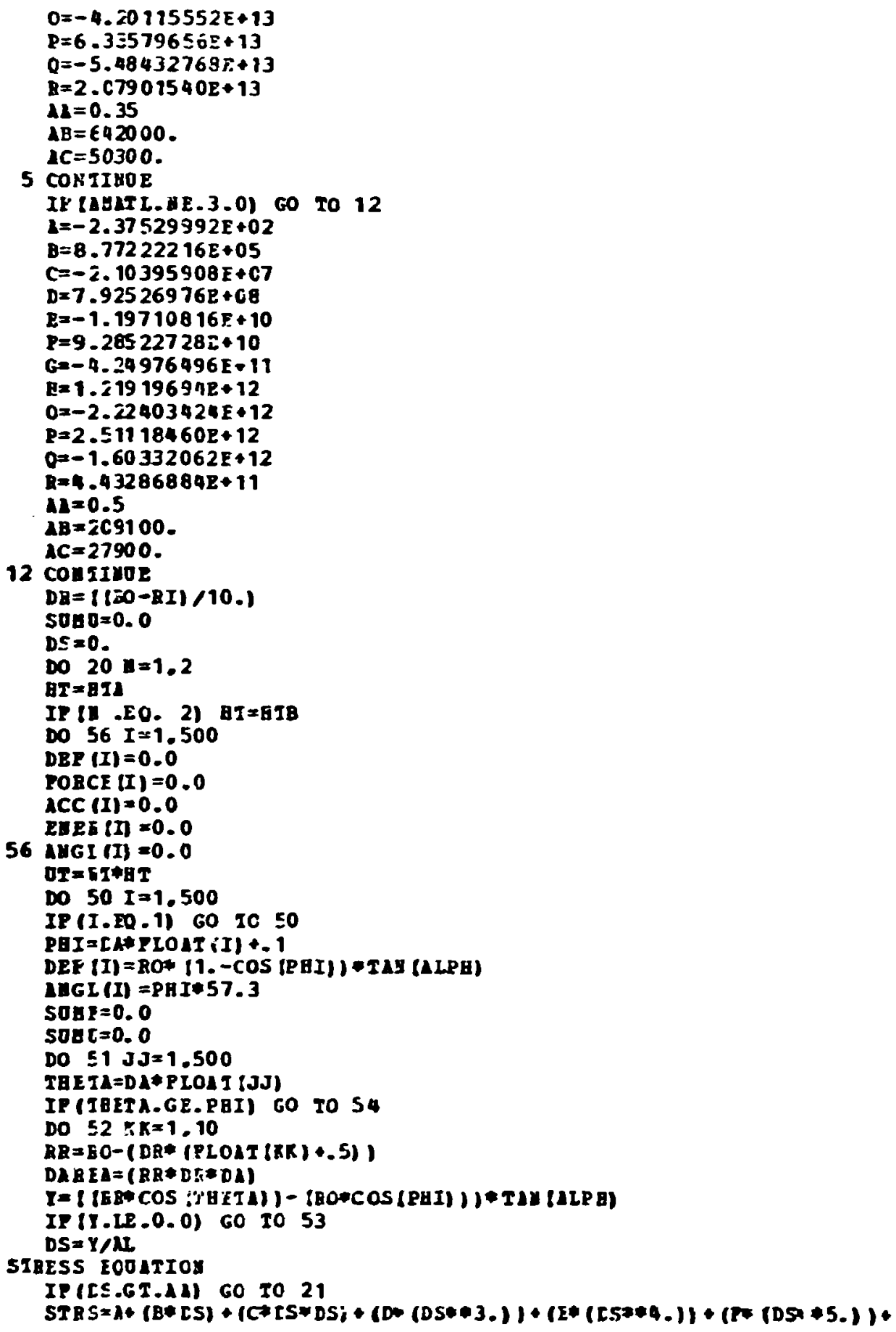




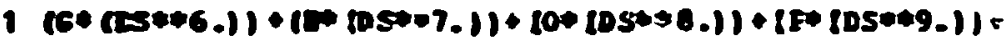

$2(00.5610 .1)+(2 *(0)=11$.

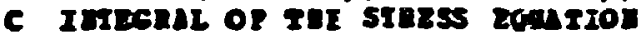

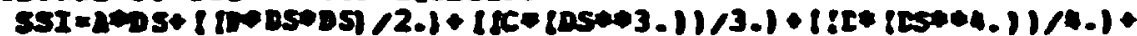

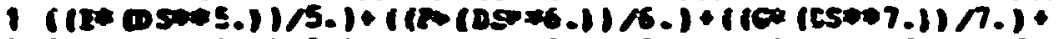

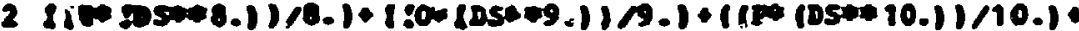

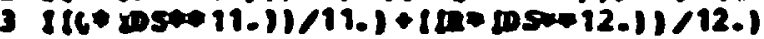

21 congres

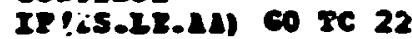

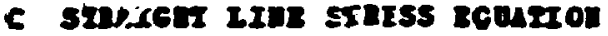

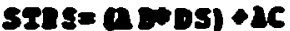

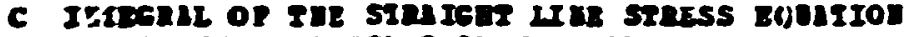

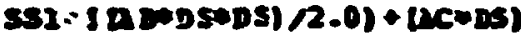

22 Conrruz

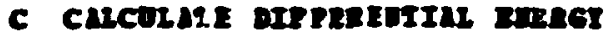

Desstonethe

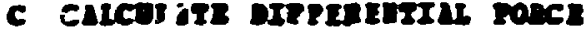
B.OS=gersenes

c sem rover

sonesuretros

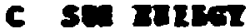

sonosinete

53 controv

52 conzine

51 congres

S4 conriver

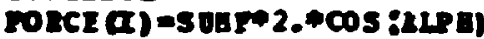

ReC (I) $=$ FonCE (I) $\mathrm{Nz}$

LIE II =SOAO: 2 .

IT (AEL (I) . GE. II) CO 2055

IR (EIII (I).GE.0I) 60 20 55

50 Cointros

ss confItus

$j=1$

GII2 86.1002$)$

DEII $(6.1002)$

EIII 86.1001$)$

DIII2 $(6.1000)$

UIII $(6.1001)$

DI25 86.1002$)$

$01282(6.1002)$

DEIRE $(6,1001)$

DII28 $(6.1003)$

DRIIE $(6,1007)$

EIIE $(6.1004)$

WIIT 8.1001$)$

WI8I (5. 1005) 10.nI $\triangle I$

UIIER (6.1011)

D2I21 86.1002$)$

GRIIE $(6.1001)$

리 $(6.1006)$

DEI2 $(6.1001)$

प2IT $(6.1007)$

WIIE $(6.1001)$

NIIE 86.1008192 .02 .02

DeI52 (6.1091)

पะII2 $(6.1002)$ 


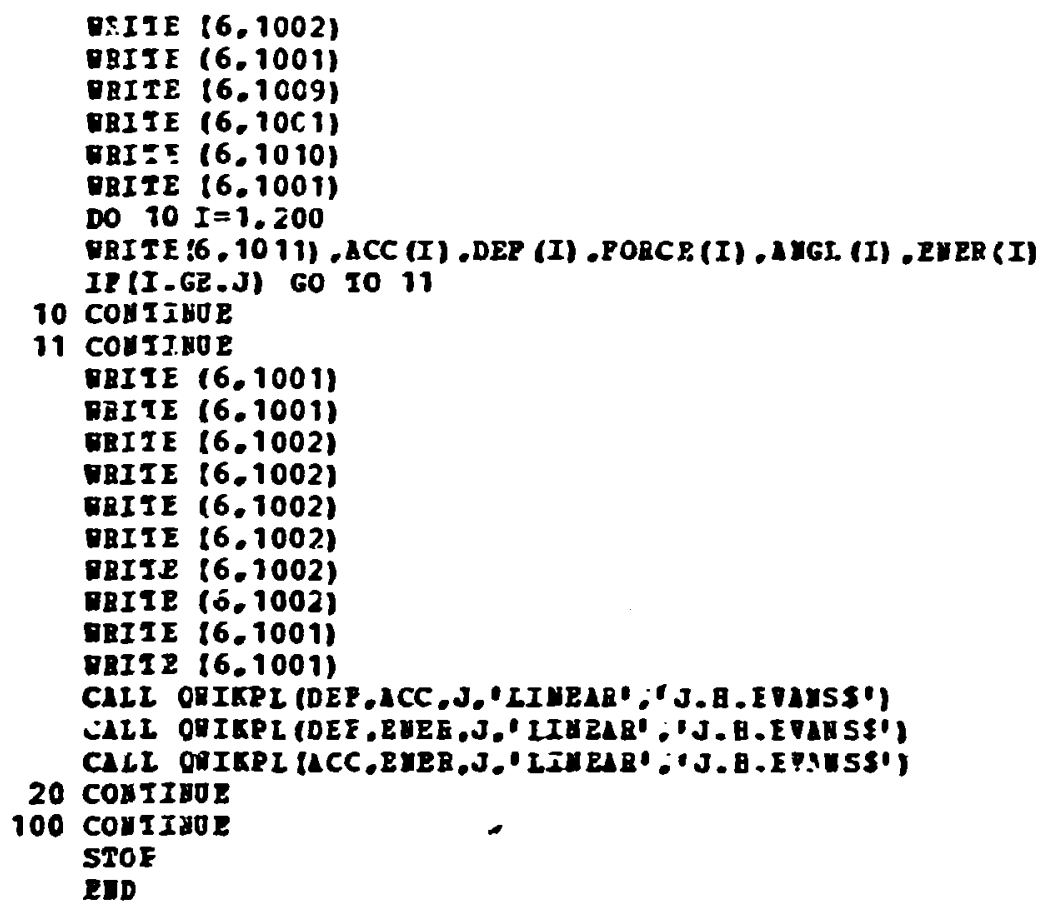




\section{Progran 1010 CASR \\ Derivation of Equations}

The ptrogran 1010 CASR is used to compute the response of a cask equipped with an energy absorber for which the force deflection relationship is known and an expression exists such that

$$
P=f(x),
$$

where

$$
\begin{aligned}
& P=\text { force }, \\
& X=\text { deflections } .
\end{aligned}
$$

The program works by computing values of force for assigned values of deflection incremented in equal increments of $\Delta x$, calculating the corresponding energy from the suming expression,

$$
U=\tilde{Z}\left(F_{n-1}-F_{n}\right)_{2} \Delta X,
$$

and composing the energy absorbed with the casks potential energy until the energy dissipated equals the potential energy as the absorbers' maxium deflection is reached. 


\section{Glossary of Notation}

$$
\begin{aligned}
& \text { OD - outside diameter of pipe } \\
& \text { THR - wall thickness } \\
& \text { W - weight } \\
& \text { SD - outside diameter of model } \\
& \text { DEFM - model deformation } \\
& \text { SF - scale factor } \\
& \text { DX - incremental deformaticn } \\
& \text { ANP - number of pipes } \\
& \text { DRH - drop height } \\
& \text { P - force applied to pipes } \\
& \text { Y - deformation of pipes } \\
& \text { E - energy dissipated }
\end{aligned}
$$

$A, B, C, D, F, G, H, A A, B B, C C, D D$ - polynomial constants 


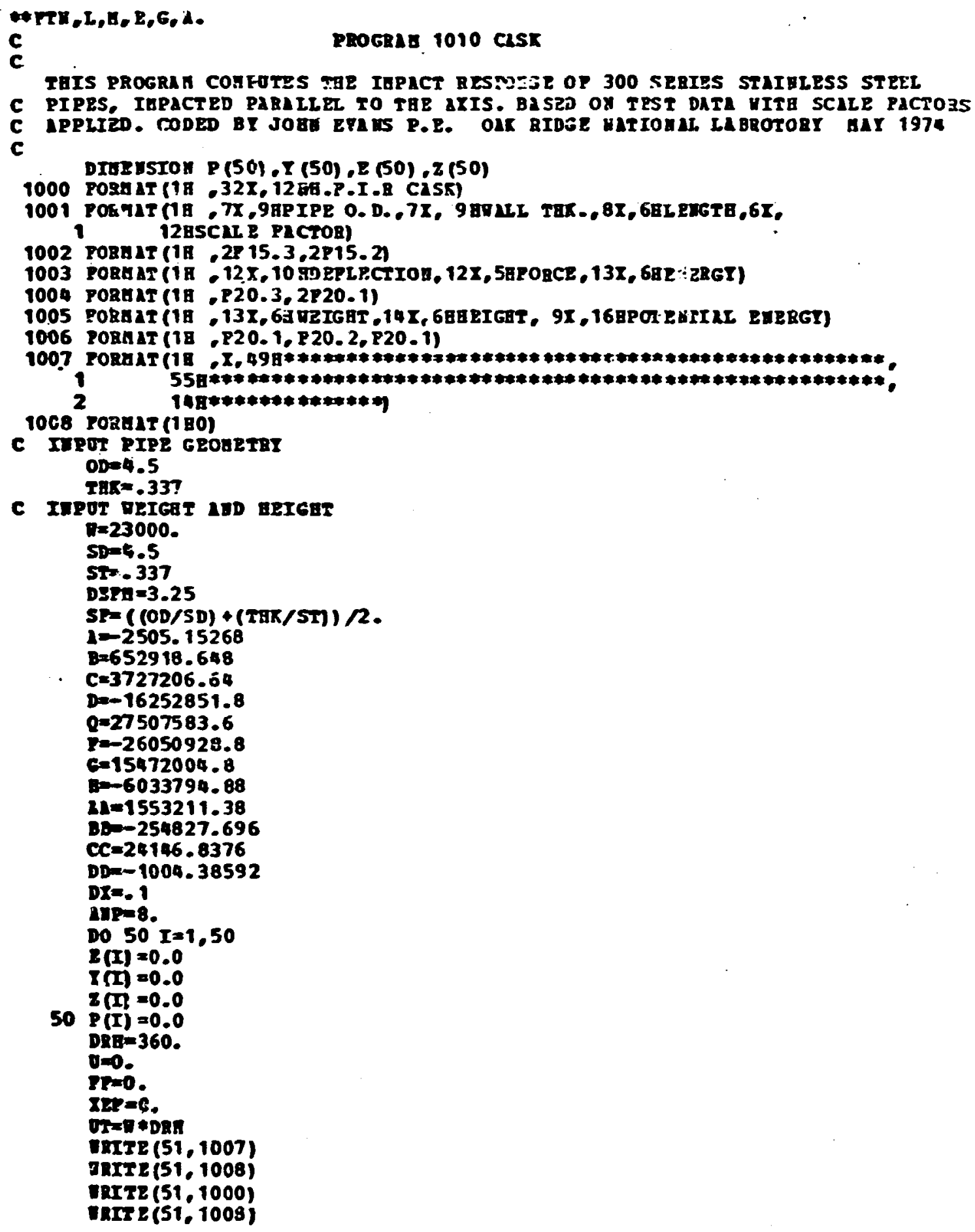




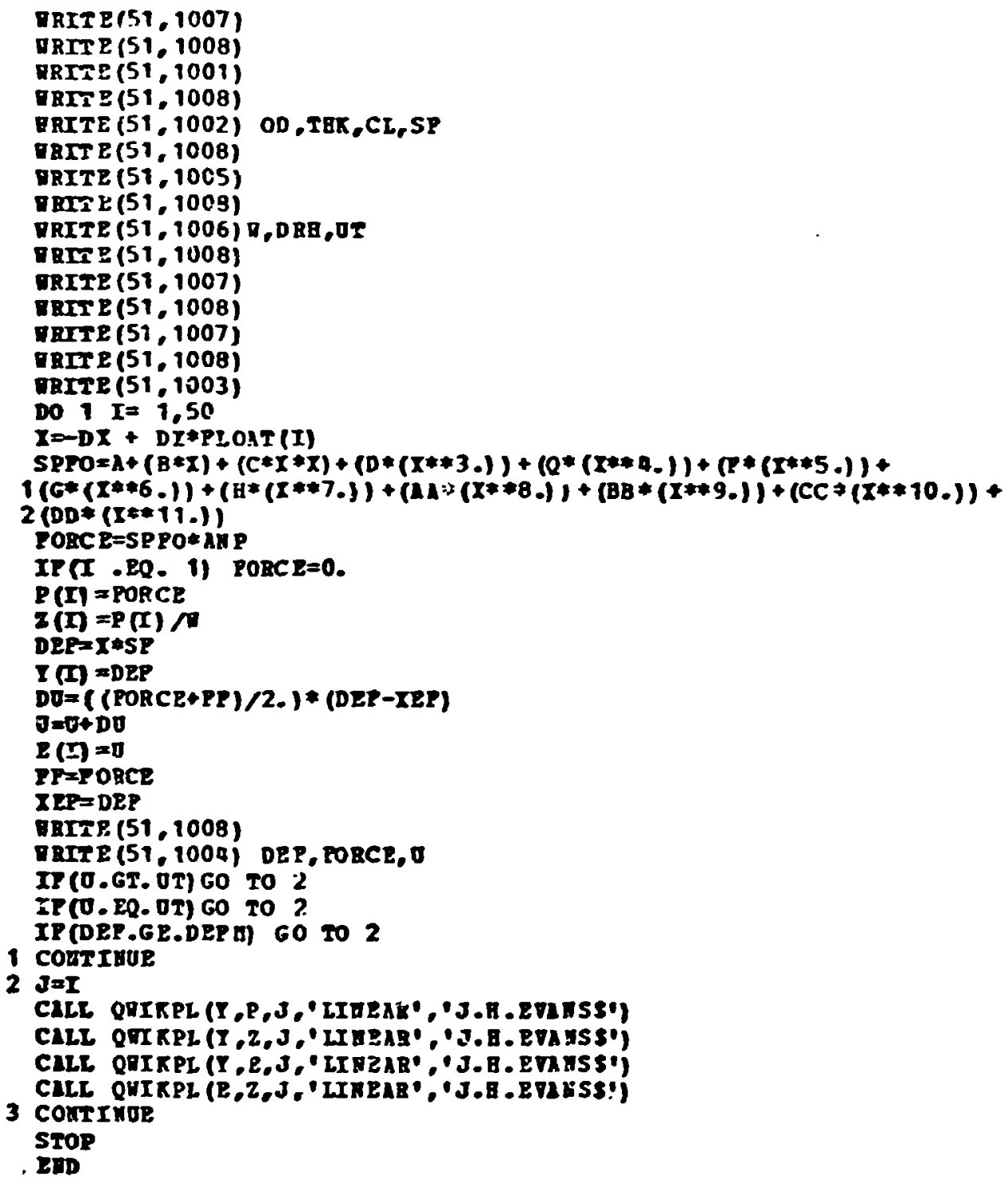

$2 \mathrm{I}=\mathrm{T}$

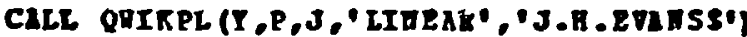

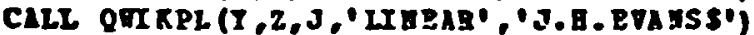

CLLL QRTKPL (Y,R,J, LIRZAR', J.B.EVASS")

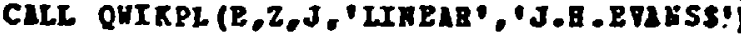

3 ConTrinde

STOP

, EDD 
Appendix $G$

OPERATING PROCEDURES AND INSPECTION CHECKLISTS 


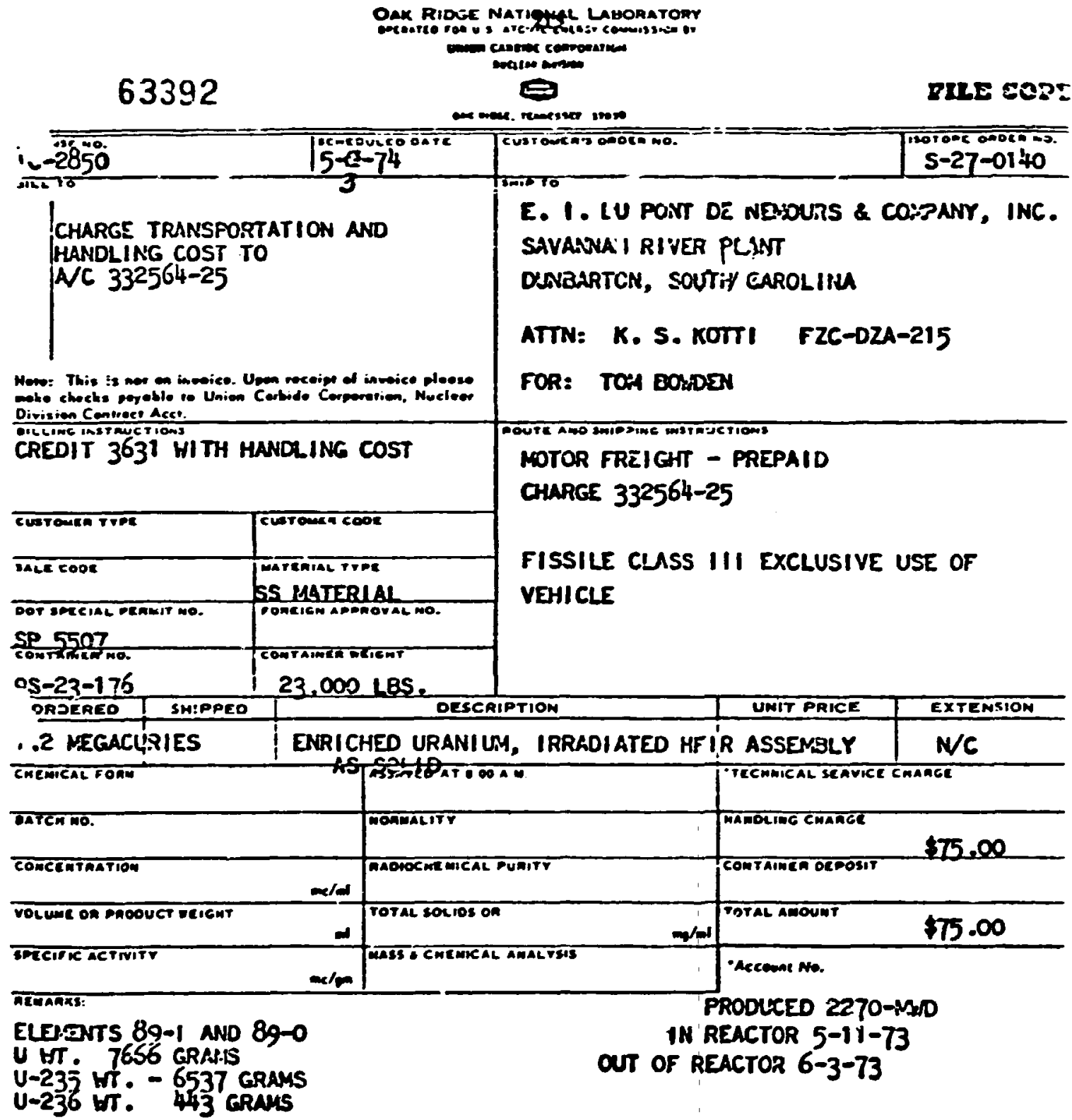

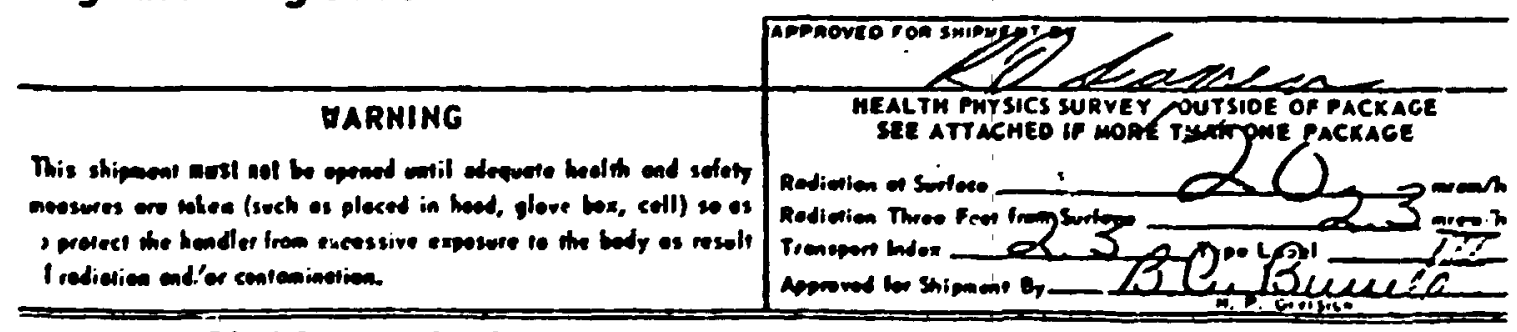

CAUTION: MEW DRUG LIMITEO BY FEOERAL LAW TO INVESTIGATIOMAL USES THIS MATERIAL MAS MOT BEEN STERILIZEO OR TESTED FOR PYRCGEMIC MATERIAL

2 


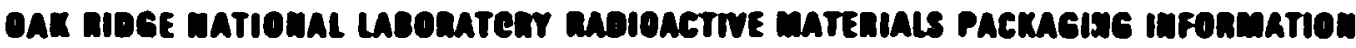

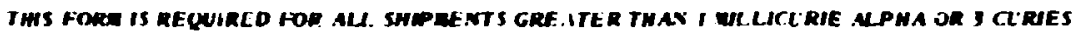

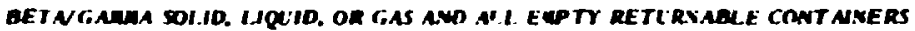

\begin{tabular}{|c|c|}
\hline 1. Ortean (Burteine) & 2. Draticution \\
\hline 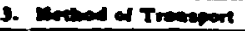 & a verest \\
\hline 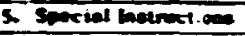 & \\
\hline & e Complind by \\
\hline & \\
\hline 1. All Dojer activitios & \\
\hline
\end{tabular}
2. Smeif (o: $\square$ romel Fare
(b) $\square$ sackel Fon
spectial Fore No.

(c) Fiste

(D) Noarfiente

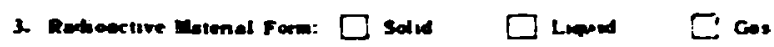

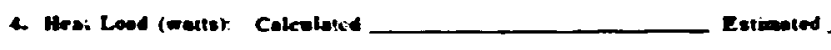

B)

\begin{tabular}{|c|c|c|}
\hline & G contamea & \\
\hline 1. Certificene st Complience Na Usa- & & \\
\hline 2. Dor Sotchification No. & 3. Naclear Safet Beriew No. & \\
\hline 4. Conterper determinod peoper for contents by & & Dote \\
\hline
\end{tabular}

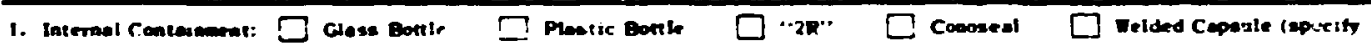
cepsole motenat:

C. Other (explam)

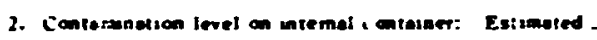

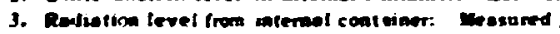

4. Caskets of ceals (ralves) propent, anstelled

5. Leak teut wh salemel contever

$-$

Colcolated Cuk

B)

Extemal contaner

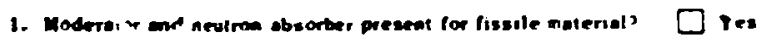

2. Extemal container exemination

3. Cosben arits properly instolled

4. Leat rest

5. Bolie ronqued in Q res

6. Tie dow io shid chected ________ $\square$ Yea

7. Taraper soul installed

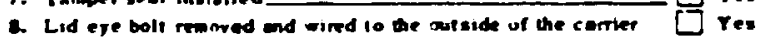

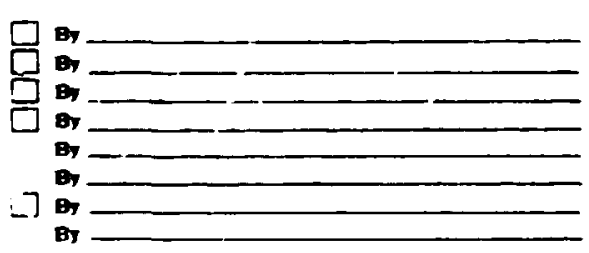

MagAnow suRver

1. Surfece contemination level: Aipha____ il

2. Exiemal rediation level dom

3. Domestic tinioments

- Poreign thipomente

mrem Me a 3 it fron surfece

3. Health Physucs Sorveyor

minem Mr 1 meter fore center

Date

\section{Twach ne-Dons MO SWOANG}

1. Tiedown and shorine in accordence with sARP and Desioned Leyoul cheeked by

(Inspeciom [nginesing

Shiomeni Aporoved By


LOADING AND SHJPPING PROCEDURE FOR DEPLETED HFIR ELEMENTS

1. As soon as the shipping cask is received, flush the inside thoroughly to the ILW system. The inside volume is approximately $40 \mathrm{gal}$; therefore, a flush of approximately $80 \mathrm{gal}$. is required. This is accomplished by connecting the demineralized water supply to nozzle no. 2 and the ILW drain line to nozzle no. 1 (Fig. E.I).

2. The outside of the cask shall be decontaminated to less than 1000-dpm transferable $\beta-\gamma$ and $30-d p m$ transferable alpha.

3. Arrange the depleted elements in the pool to facilitate their loading.

4. Attach the lifting sling assembly (Appendix A, Fig. A.6) to the 50-tcn overhead crane.

5. Attach the cask-1ifting sling assembly to the transfer cask, and attach the 1id-1ifting device. Remcve the fourteen 1-1/2-in. 1id holddown nuts.

6. Remove the 11d and determine that the center Yoison post and liner are in the cask and secured in place.

7. Visually inspect the cask gasket; replace if damaged.

8. Lift the assembly $1 \mathrm{in}$. off the floor and check the rigging to ensure that a proper and adequate hookup has been made.

9. Attach the aluminum disc to the button of the cask.

10. Move the tranafer cask to the spent fuel shipping container pad in the west clean pool. CAUTInN: When making this move, do not permit the cask to pass rver the vessel or any stored elements. 
11. Raise the 1id to clear and move it aside.

12. Remove the outer element holddown ring with the tool provided.

13. Load the outer element into the cask.

14. Load the inner element and insert the outer element holddown ring. Make sure the cask plug gasket is in place.

15. Replace the transfer cask lid.

16. While continuously monitoring the radiation intensity, slowly raise the transfer cask. Stop raising the cask when tt is high enough to permit replacement of the 1 id holddown nuts.

17. While monitoring the radiation intensity, raise the cask all the way out of the water and rinse it thoroughly with demineralized water.

18. When the cask has dripped dry, transfer it to the decontamination pad while monitoring the radiation intensity.

19. Replace the holddown nuts and torque to $100 \mathrm{ft} \cdot 1 \mathrm{~b}$ using a crossing pattern in steps of $50 \mathrm{ft} \cdot 1 \mathrm{~b}$.

20. Perform pressure tests as follows:

a. Pressurize the cask lead cavity to 10 psig using nozzle no. 4 (Fig. E.1). Close valve; disconnect air supply. There shall be no detectable loss of pressure after a perfod of $15 \mathrm{~min}$ as measured on pipe plug in nozzle no. 4.

b. Pressure-check the cask plug cavity as in a; use nozzle no. 3 . Replace pipe plug in nozzle no. 3 .

c. Pressurize the element cavity to 20 psig using nozzles no. 1 or no. 2 (Fig. D.1). llose valve; disconnect atr supply. There shall be no detectable loss of pressure after a period of $15 \mathrm{~min}$. 
21. While continuing to monitor the radiation intensity, remove the water frow the element cavity to the ILW. This is accouplished by applying 5-psi air pressure at nozzle no. 2 and connecting the ILW drain line to nozzle no. 1. Continue water removal for at least 30 mins. ERDA regulations require that the dose rate at the surface should not exceed 200 millirems/hr nor 10 millirems/hr at a distance of $1 \mathrm{~m}$.

22. Decontaminate the outside of the cask to less than $1,000-\mathrm{dpm} 3-\gamma$ and 30-dpm alpha transferable contamination.

23. Have the Health Physics Division representative check and tag the cask. 
PROCEDLRE FOR LOADING THE FUEL CASK AT THE ORR

A. Remove the cask from the delivery truck.

1. Place blotting paper or the floor area west of the $2 d-1$ evel c-zone (an area sifghtly larger than the base of the cask is adequate).

2. Using the A-frame assembly and the 20-tcn overhead crane, remove the cask from the delivery truck and place it on the bloting paper. Ensure that the lifting device is properly attached to the 20-ton hook and that none of the chain lines are twisted (Fig. 3.6a).

3. If remov $1, n g$ the cask from the delivery truck is the only objective at this time, remove and store the A-f zame lifting assembiy. However, if it is anticipated that the cask can be loaded soon after delivery to the ORR, the dam must be insta:led between the reactor and center pools before the crane is used for the A-frame operatiun.

B. Prepare the cask for the pool.

1. Have the health physicist check the cask for transferable contamination. NOTE: If the cask is contaminated (that is, $>1000 \mathrm{dpm}$ per $100 \mathrm{~cm}^{2}$ beta-gamma and/or $>30 \mathrm{dpm}$ per $100 \mathrm{~cm}^{2}$ al.pha), the cask must be cleaned before it is placed in the pool water.

2. Examine the cask for (1) possible damage incurred during transit, (2) radiation-identification and/or other tags, (3) debris, and

(4) a wire used to seal the lid. Remcve any tags, debris, and/or the wire seal.

3. Remove the nuts securing the top.

4. Inspect the gasket. (CAUTION: To accomplish this, th=1id inust be raised slightly using the chain hoist on the A-frame; have the health pliysicist monitor the radiation level of the cavity as tine 1id is raised.)

5. Inspect the inside of the cask; that is, the ORR fuel element magazine should be in place, secure.:, and free of damage.

C. Place the cask into the center pool.

NOTE: If applicable, raise the cask 1 1n. off tin tloor to be surc that a proper hookup has been made.

1. Raise the cask to the upper-1imit travel of the 20-ton crane.

2. Position the cask over the center pool.

3. Attach a 1-in.-diam rope to the cask top; the remainder of the rupe should be placed on the motorized bridge. 


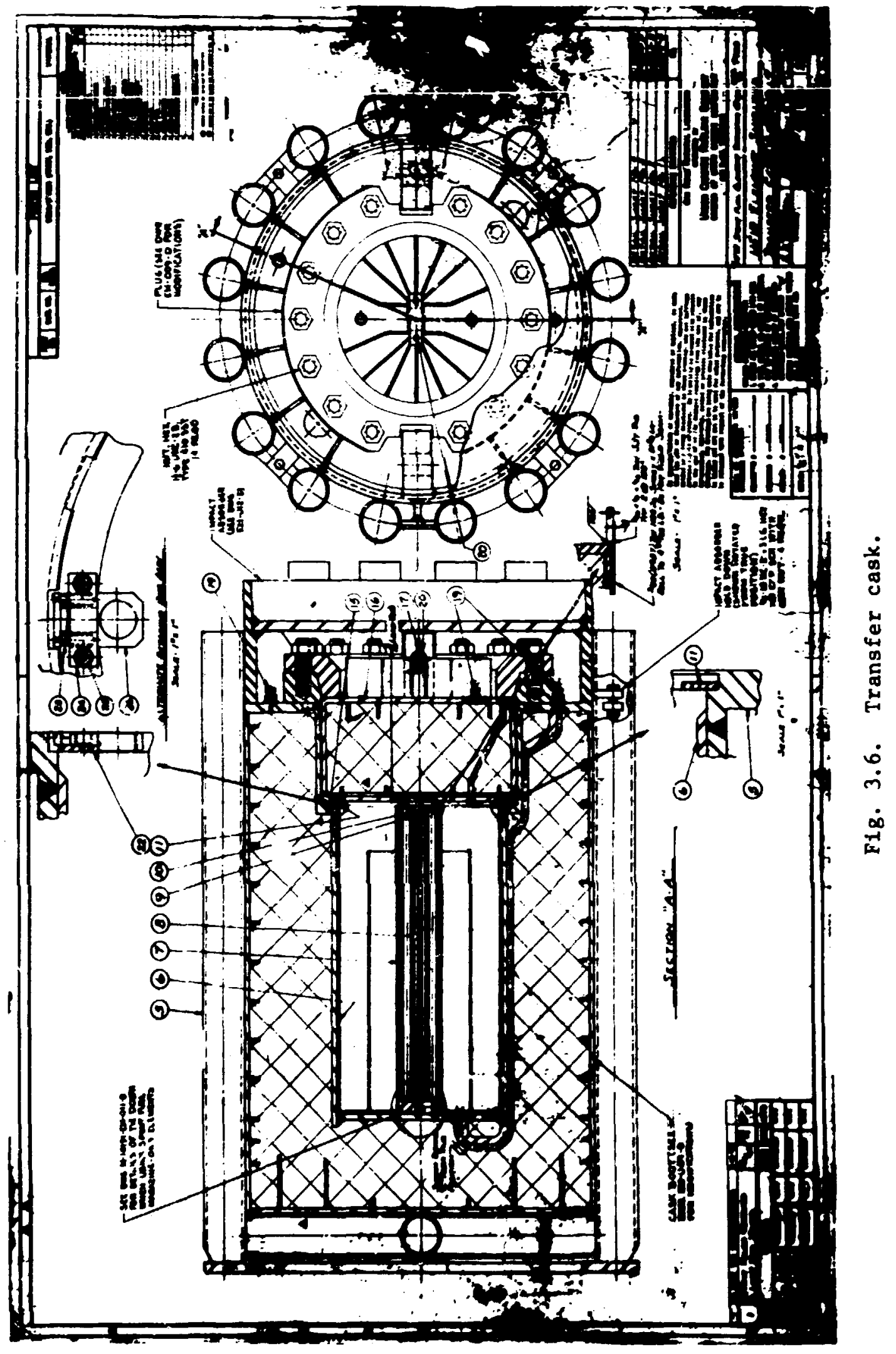




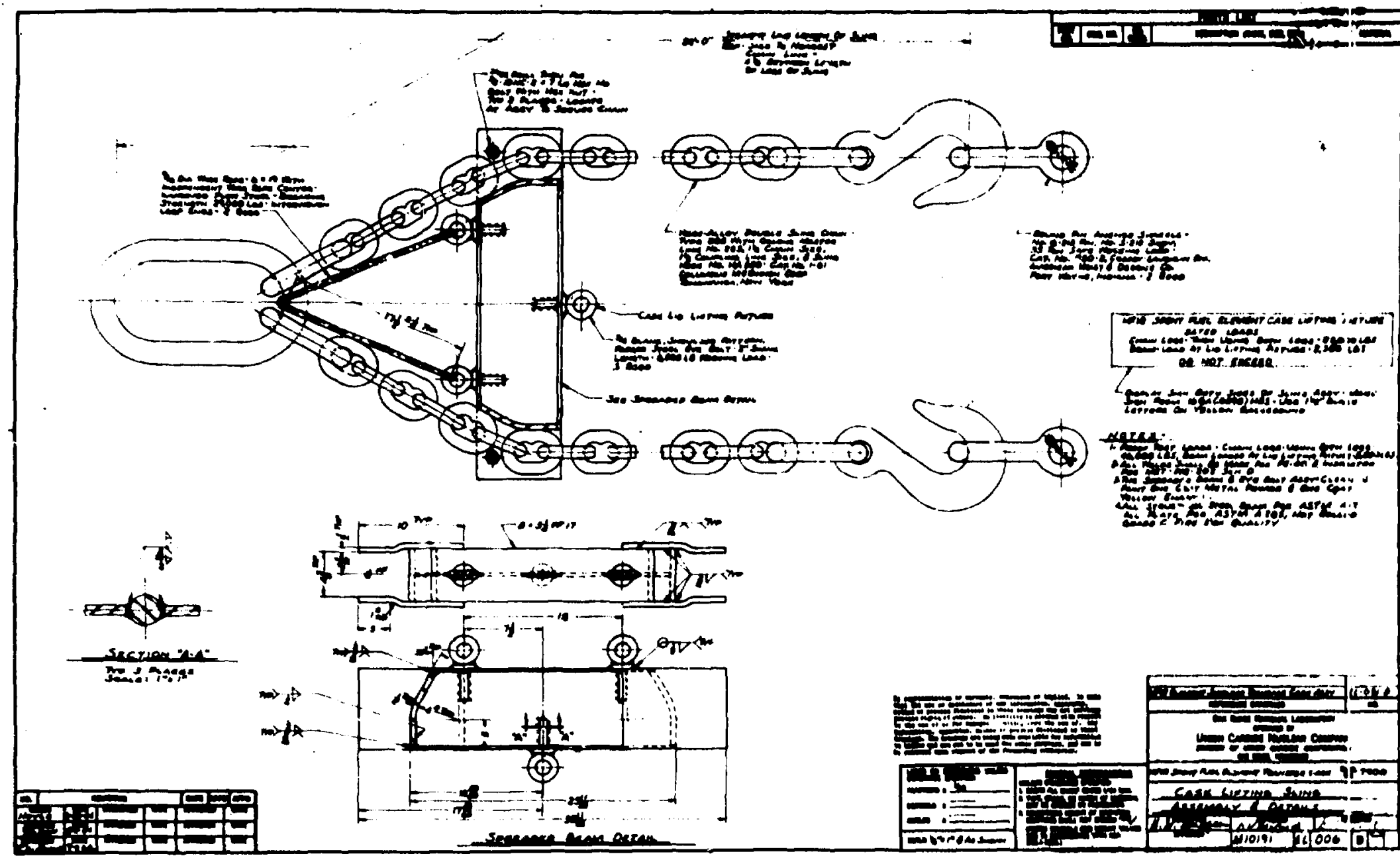

F1g. 3.6a. Lifting sling. 
4. Spray the cask with demineralized water. (This step is found to be somewhat effective in "sealing" the porous metal surface of the casi from the contuminated pool wate: and, conscquentiy, factl1tates the decontamination procedure upon removal.)

5. Slowly lower the cask into the pool until the top of the cask is at about the same depth as the top of the two 7-element storage racks located on the grating. Position the cask as close as practical to the storage racks. (Normally it will be lowered into the pool on the east side then moved westuard.) Due to the size of the cask, extrewe care must be exerrised in manipulating the cranc contruls for the positioning of the cask. (CAUTiON: Ensure that the cask is not allowed to collide with the pool liner or any in-pool equipment. The shift engineer must observe this activity.)

6. Using the chain hoist, raise the cask top until the base of the top plug is about 2 in. above the vertical pipe sections and fins on the cask sides.

7. Secure the 1-in.-dian rope to the motorized bridge and move the bridgs eastward until the top is muved away from the mouth of the cask.

D. Load the cask.

1. Place the electrical breaker for the overhead crane in the OFF position (located on the southside walkway of the $3 d$ level). This switch must remain in the OFF position until the 17 elements are loaded and the cask's top plug is positioned over the mouth of the cask.

2. Usiag the pincer-1ike swivel tool, raise a fuel element from the 7-element storage rack. Moritor the radiation level at the pool Darapet during this step.

3. Identify the element number; it should correspond to one listed under "element number" of the fuel element shipping form.

4. Place the element in one of the 17 positions in the shipping cask basket.

5. Record on the fuel element shipping form (see example) the position in which the element was placed relative to the yellow lifting lug inside the element basket or magazine. (NoTE: The yellow lug location will have to be indicated on the schematic diagram of the basket positions show on the shipping form.)

6. Repeat steps 2 through 5 unt 11 the 17 elements have been loaded into the cask. (CAUTION: Do not attempt to expedite the loading procedure by either transferring more than one fuel piece at a time or by removing the cask's 17-position lasket.) 

E. Insiall the ton on the luâủeủ cask.

1. Move the motorized bridge westward until the cask top is positioned over the mouth of the cask.

2. Using the chain hoist, lower the cask top into the seated position. (Two guide pins are provided on the cask to facilitate the necessary alignment.)

3. Carefully inspect the cask top for proper seating. If one side appears uneven, raise the lid and repeat step 2.

4. Place the electrical bleaker for the overhead crane in the ON position.

F. Remove the loaded cask from the pool.

1. Position the cask in the pool so that it can be zaised without obstruction from in-pool equipm:nt. (CAUTION: Ensure that the cask is not allowed to collide with the pool liner or any in-pool equipiuent. The shift engineer must observe this activit;.)

2. Have a health physicist monttor the radiation level of the cask as it is slowly raised from the wacer. If the radiation level is in excess of $200 \mathrm{milli}$ rems/hr at contact, inform the reactor sipervisor.

3. As the cask is being raised, rinse it with demineralized water.

4. When access to the cask top is achieved (while standing on the motorized bridge), place the nuts on the studs and secure them, tnrque to $100 \mathrm{ft} \cdot 1 \mathrm{~b}$ in $5 \mathrm{~J}-\mathrm{ft} \cdot 1 \mathrm{~b}$ increments.

5. Ri-move the 1-in.-alam rope.

6. Using rags, wipe all surface areas of the cask while it remains susperided ovar the pool, preferably before it is allowed to dry.

7. Return the cask to its original position in the truck bay; however, leave the cask suspended about $4 \mathrm{ft}$ above the floor level.

8. Have the health physicist obtain a smear of the bottom surface of the base. If the transferable contamination level is $<1000$ dpm per $100 \mathrm{~cm}^{2}$ beta-gamma and $<30 \mathrm{dpm}$ per $100 \mathrm{~cm}^{2}$ alpha, lower the cask to the floor. If it is contaminated in excess of the specified limlts, repeat the cleaning operation of the cask base.

9. Remove the A-frame assembly and return it to storage if applicable (that is, if the cask is not to be shipped relaifvely soon). 
G. Perforn pressure tests as follers:

NoTE: See Pig. 3.6 For nozzle location. In each case below, apply alr pressure. Close inlet air valve and disconnect air line. observe gauge. If pressure decreases before end of test period, notify supervision.

1. The cask lead cavity should hold an atr pressure of $10 \mathrm{psig}$ for u15 nin. Nozzle no. 5 is used for this test.

2. The flug lead cavity should hold on atr pressure of 19 psig for w15 nin. Nozzle no. 3 is used for this test.

3. The element cevity should be pressure-tested at 20 psig for ح 30 in. Nozr.le nos. 1 or 2 way be used for this test.

H. Purge the pool water frow the cavity of the cask.

1. Connect the clear Tygon-hose end of the drainline assembly to the ILW valve located on the north balcony (labeled 42 ). (NOTE: "Clear" Tygon hose 18 used for this application t: allow the easy viewing of the purged water; however, in order to comply $w$ th the requirement of using only "colored" Tygon hose at the ORR to ensure visibility In the event any of the plastic would ever be placed in the pool, a colored-tape wrapping 18 secured to the hose at various locations.)

2. Remove the cap from the cask's drainline.

3. Connect the other end or the drainline assembly to connection 1 on the cask top (Fig. 3.6b).

4. Ensure that all connections are secure, then open the valve to the ILW system.

5. Remove the cap and plug from the cask's connection no. 2:

6. Connect the end of the aIr-purge supply line Into the cask's top vent.

7. Connect the other end of the alr-nurge supply line to the plant ail-supply line (located by th: stairway) (F1g. 3.6c).

8. Ensure that all connections are secure. (NOTE: If the connections are not secure, the contaminated pool water will be forced out. around the gasket area, and it will recontaminate the cask. In addicion, an inadequate purge will be established due to the $108 \mathrm{~s}$ of air pressure.)

9. Adjust the alr regulator unt1l the pressure gauge Indicates 5 psig. (CAlTTION: Do not pressurize the cavity over 5 p8ig without explanation.) 
10. Open the air-supply valve to the cask. At this time water should be observed leaving the cask through the clear Tygon hose. (CAUTION: The radiation level of the water mist be monitored.)

11. After all the water has been removed (normally after wlo min the water flow through the clear tubing will cease), purge the cask with dry air for $1 / 2 \mathrm{hr}$ to remove all water and then close the air-supply valve and verify that the fressure (indicated on the gauge) decreases to zero.

12. Remove the drainline fitting from the cask and allow the negative pressure of the ILW system to remove any residual water in the Tygon hose.

13. Install the cask's drainline cap.

14. Remove the air-supply line from the cask and install the plug and cap. (NOTE: Wrap a piece of pipe tape around the threads of the plug before reirstalling it.)

15. Place the air-purge and drainline equipment in a plasic bag and return them to the storage box.

I. Prepare the cask for shipment.

1. Have the health physicist determine the contamination and radiation status of the purged cask. Continue the cleaning operation as needed to decontaminate the cask to the specified limits listed previously. The beta-gamma radiation level, after removing the water from around the fuel pieces, should not exceed 200 millirems/ hr at contact anywhere on the cask; if it does, the reactor supervisor should be notified.

2. Have the health physicist prepare a radiation-identification zag (that is, a Radiation Hazard Materials Transfer tag), and secure it to the cask.

3. Inform the reactor operations foreman in charge of maintenance that the cask is prepared for shipment from the ORR butlding, and submit to him the fuel element shipping cask form. He will initiate the arrangements for the cransfer of the cask from the ORR building. 
HeIR Cask Loading Checl. Llst

pace

Type Shipment

HPIR Elément $\square$

Shipone to.

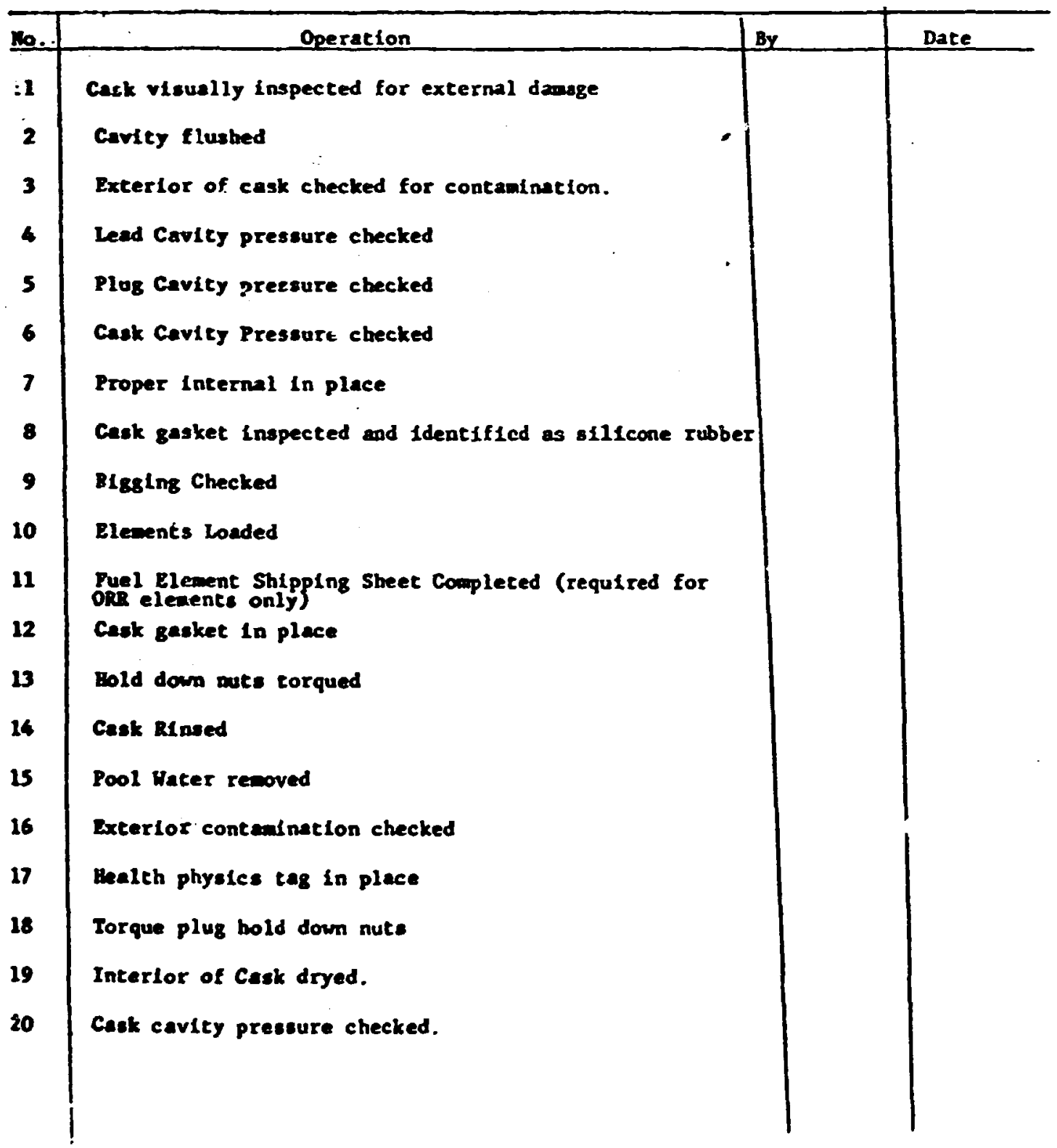


Appendix H

ACCIDENT SHIELDING ANALYSIS 
RADIATION SAFETY EVALUATION DF THE HFIR ELEAENT SBIELDED TRANSFER CASK

A study of the radiation safety of the HFIR elewent shielded transfer cask using the ANISN ${ }^{1}$ discrete ordinates transport code and 18-group gamma cross sections was made. For the purpose of this study, a source of gamma rays for a 240-day postirradiation period after 15 days of operation ${ }^{2}$ was used. It was assumed that the relative number of gamma rays at various energies at 15-days exposure would not be significantly different from those at 23-days exposure desired for this stidy. An infinite cylinder geometry with the gama source unfforn.'y distributed over the fuel region $\because 13$ assumed since such a representation should give dose rates as great as those obtained from the real cylindrical cask.

The centering fust was described for the problem as a homogenized mixture of aluminum, stainless steel, and void. Similarly, the fuel region was made up of homogenized uranium, aluminum, and void. The amount of each material in the homogentzed mixture was determined from the volume fractions of that material in the actual cask assembly. Type 304 stainless steel was used for all stainless steel parts. The only damage considered was the loss of melted lead due to a fire.

The same gamma source was used for the undamaged and the damaged casks. Dose rates at the surface and 3 it from the surface were scaled to a source ylelding $10 \mathrm{mlllirems} / \mathrm{hr}$ at $3 \mathrm{ft}$ from the undamaged cask. The results are given in Table 1.

Table 1. Dose rates from HFIR element transfer cask

\begin{tabular}{lcc}
\hline Condition & $\begin{array}{c}\text { At surface } \\
\text { (millirems } / \mathrm{hr})\end{array}$ & $\begin{array}{c}\text { 3 ft from surface } \\
\text { (millirer.s/hr) }\end{array}$ \\
\hline Undamaged & 31 & 10 \\
Damaged & 6838 & 222 \\
\hline
\end{tabular}

The dose rates at tie surface and at $3 \mathrm{ft}$ finm the surface of the damaged cask are about 22 times as $h \mathrm{~g}_{\mathrm{g}}$ as the rates for the undamaged cask. Since the allowable dose rate for the damaged cask at $3 \mathrm{ft}$ from 
the surface is 1000 millirems/hr as compared with the calculated value of 222 millirems $/ \mathrm{hr}$, the cask satisfies the requirements for safety under the conditions assumed for purposes of this evaluation.

\section{References}

1. W. W. Engle, A User's Manual for ANISN, K-1693 (March 1967).

2. J. H. Evans et al, Analysis of HFIR Irradiated Fuel Element Shipping Casi, ORNL/TM-959 (January 1965). 
Appendix I

CRITICAL;TY REVIEW FORMS 


\section{INTRA-LABORATORY CORRESPONDENCE \\ OAK RIDGE NATIONAL. LABORATORY}

July 18,1973

TO:

R. G. Affel

SUBJECT: NSR Request 467

NSR Request 467 concerning routine shipwents of spent HFIR fuel elements at the HFIR expired in March, 1973. Routine shipments of spent HFIR fuel elements and operating procedures have not changed since Request 467 was approved. Please extend the expiration date of this Request as appropriate.

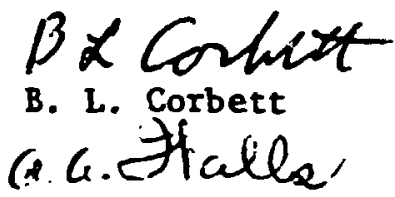

A. A. Walls

$B L C: k j f$

I.ify 30, 1973

To: Criticality Comiltee

B. I. Corbett

A. A, Walls

NSR Request 467 is approved to be extended througn July, 1975, based on the above statement. Should changes occur in the shipping procedures during that time, this office must be notified.<smiles>CCCCCCCCC</smiles>

R. G. Affel

Safety \& Radiation Control 


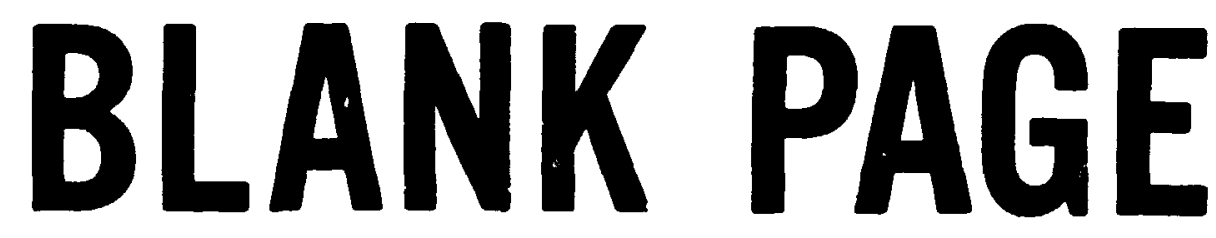




\section{INTRA-LABORATORY CORRESPONDENCE}

OAK RIDGE MATIOMAL LABORATORY

August 29, 1975

TO: Rig. Affel

SUBJECT: MSR Request 467

HSR Request 467 concerning routine shipments of spent HFIR fuel elements at the BFIR expired in July, 1975. Routine shipments of spent BFIR fuel elements and operating procedures have not changed since Request 467 was approved. Please extend the expiration date of this Request as appropriate.

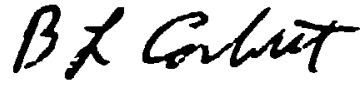

B. L. Corbett

G. Govalk

A. A. Walls

BLC:kJf

To: B. L. Corbett

A. A. Wal1s

Based on your statement above, NSR 467 is hereby extended for three years, to expire in Cctober, 1978.

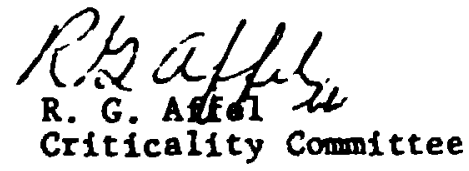

ce: Criticality Combittee 


\section{INTRA-LABORATORY CORRESPONDENCE $\quad \because ! ! \cdot \because \cdots 7$. OAK RIOGE NATIONAL LABORATORY \\ July 12,1977}

TO: G. H. Burger

FROM: $\quad$ S. S. Hurt

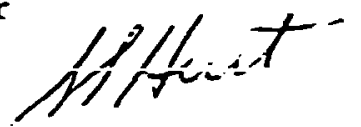

SUBJECT: Renewal of N.S.R.'s Nos. 683, 688, and 747

Please renew the subject NSR's which, correspondingly, pertain to the transfer of fuel from one approved storage facility to another, the BSR underwater fuel racks, and the HFIR carrier for ORR elewents.

There have been no changes in equipment used, nor in the procedures related to its use.

SSH: gt

cc: F. T, Binford

R. K. Branam

J. A. Cox

T. P. Hamrick

E. D. Lance

R. V. McCord

August 3,1977

To: S. S. Hurt

B. L. Corbett

MSRs 683, 688, andx 747 are extended for one year, to expire in August, 1978. This extension is based on the statement that no changes have been made in the equipment or procedures involved in these NSRs.

NSR 747 was replaced by 7851, which is good until Jaguary 1979.

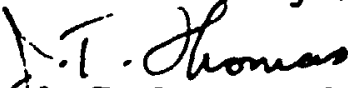

OJ. T. Thomas, Chairman

cc: Criticaity Cormittee

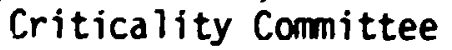

J. A. Cox 
REOUEST FOR NUCLEAR SAFETY REVIEW

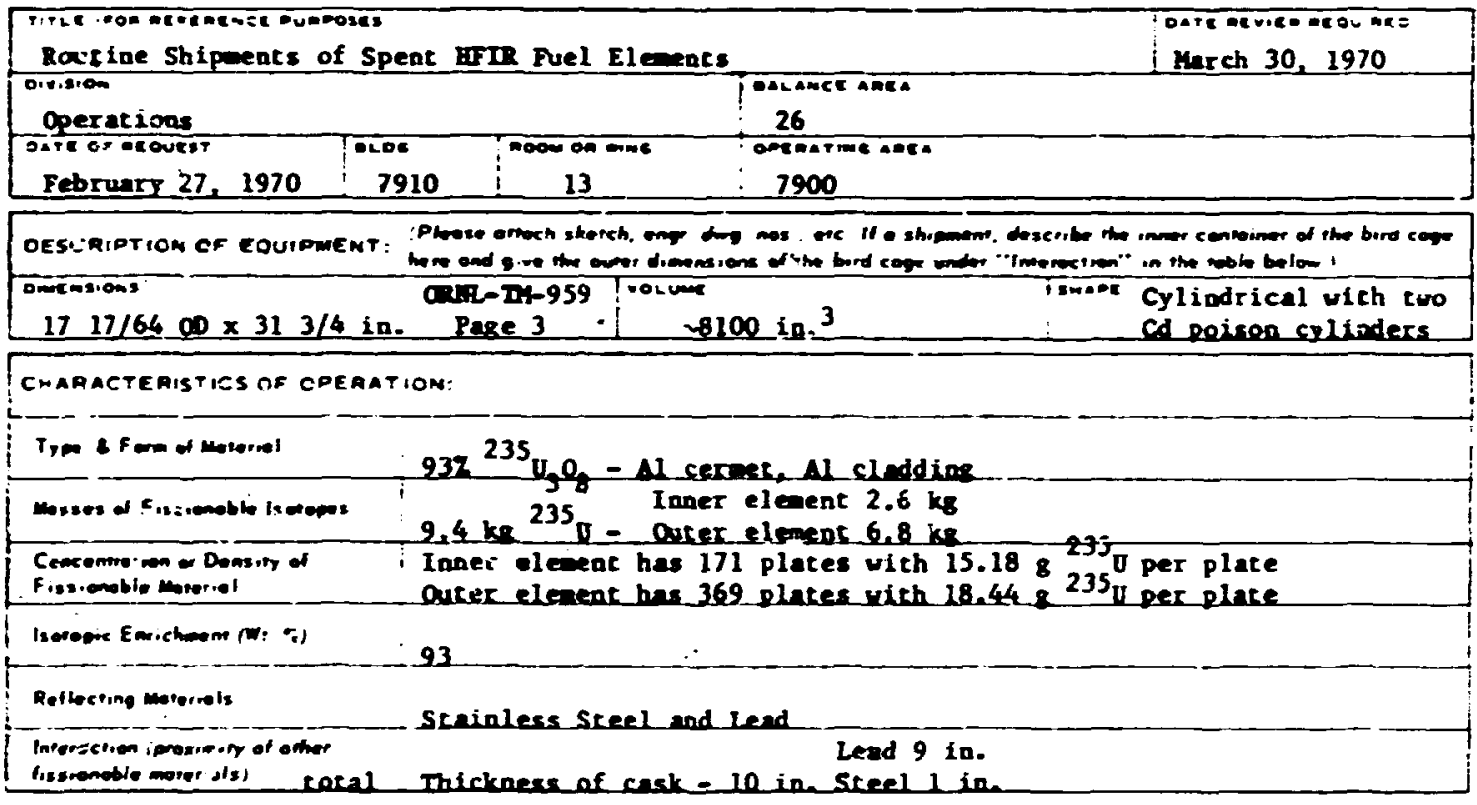

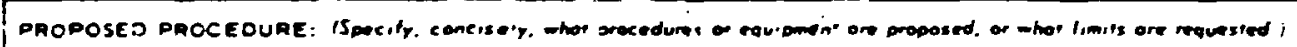

The UFIR fuel elenent shipping cask is designed to zransport one HFIR fuel assembly from and to the site of the fuel processor. The fuel elements are londed into the shipping cask in the 20-ft-deep KRIR por,. The nortbuest section of the center pool is designed as the londing area. This area is 2 ft from the closest fuel storage rack. The elements are laaded into the cask one at time by first loading the outer element and then the inner element. Tro cadmim poibor cylinders are provided on an integral part of the shipping cask to assure subcriticaltey even though a maximm reactivity (new) fuel assembly is loaded in.o the cask. After loading the eleaents into the cask and installing the ild, the cask is reaoved from the fool and a radiacion survey is made co assure that the radiation level at the surface of the container is ecceptable for shipaent. The cask is then decontominated and loaded for stipment on truck in the reacior bay. The veight of the cask is 23,000 1bs. Adequate bracing and holding dan devices are provided to stablisze the cask while in transit. If it should tecone necessary to loed the fnner and outer elentents into the cask simicaneously becaue the elements are scuck cogether, IOB poison strips will be used to poison the elements during the loading operation.

The Bureau of Explosives No. 1997 has been assigned to chis shipping cask.

This request is to replace NSR 210 .

SIONEE

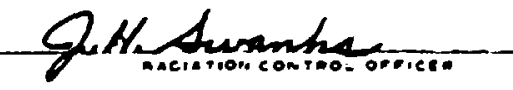

SICNED B. Comery 
Uaiess otherwise iadicated. the recommendation below expresses general xceptance of if - nuclest sufets precustions :aciorp-

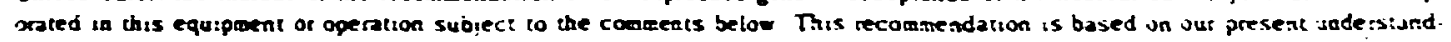

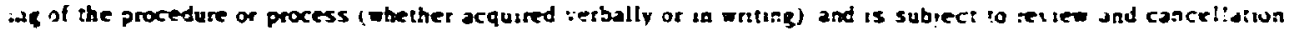

Th Condetee has reviewed the cask is described in 0an-m-95y and Irewlage H-16191 I-CCl J-60SD and has concluded that che cask meet the

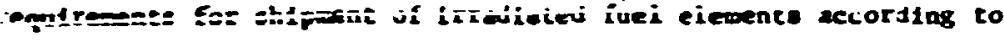
Ale Hawel Chepter U529. In Ite considerations resulte of the criticalfty experiments were revitewed. These experiments indleate the rollowing:

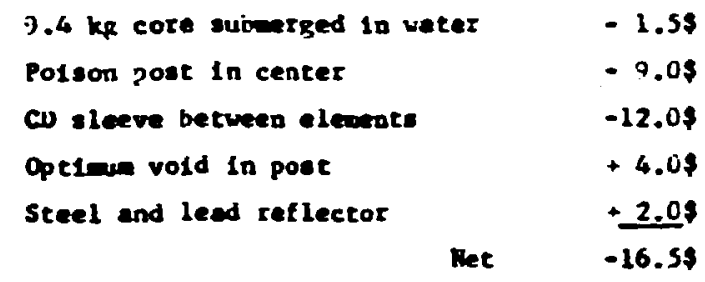

The procedure deacribed it also reccinended for approvel, but it is suggested that adadnistrative procedure to 1noure the presence of the cadadur poison be incorporated in the procedures and that coples be submitted to the conitcee.

The sonftes recoumends approval of this requeet with the underatendiag that elcesate requiring boron poleonlag or cannine be case not euvered here.
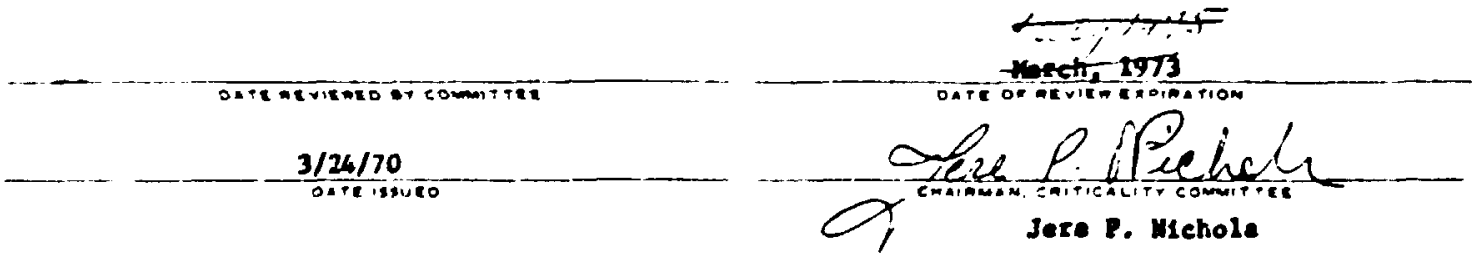


\section{REQUEST FOR MUCLEAR SAFETY REVIEW}

This request covers opentuons with tassile witenal in a control ares and or fissile materul traisfers thet onguate within the coatrol area. The coatrol srea supervisor shall complete the blocins below and dexcibe the process and/or operations to be performed. eaphasiziat the provisigas for nuclear caricality safety on the severse side of this pare. This request stwll be approvec b the Ridiation Control Officers of the orifinating Division and the Division(s) to which fissile material wall be :ransferred. bera CRITICALITY CONATIEE

1.5. 747

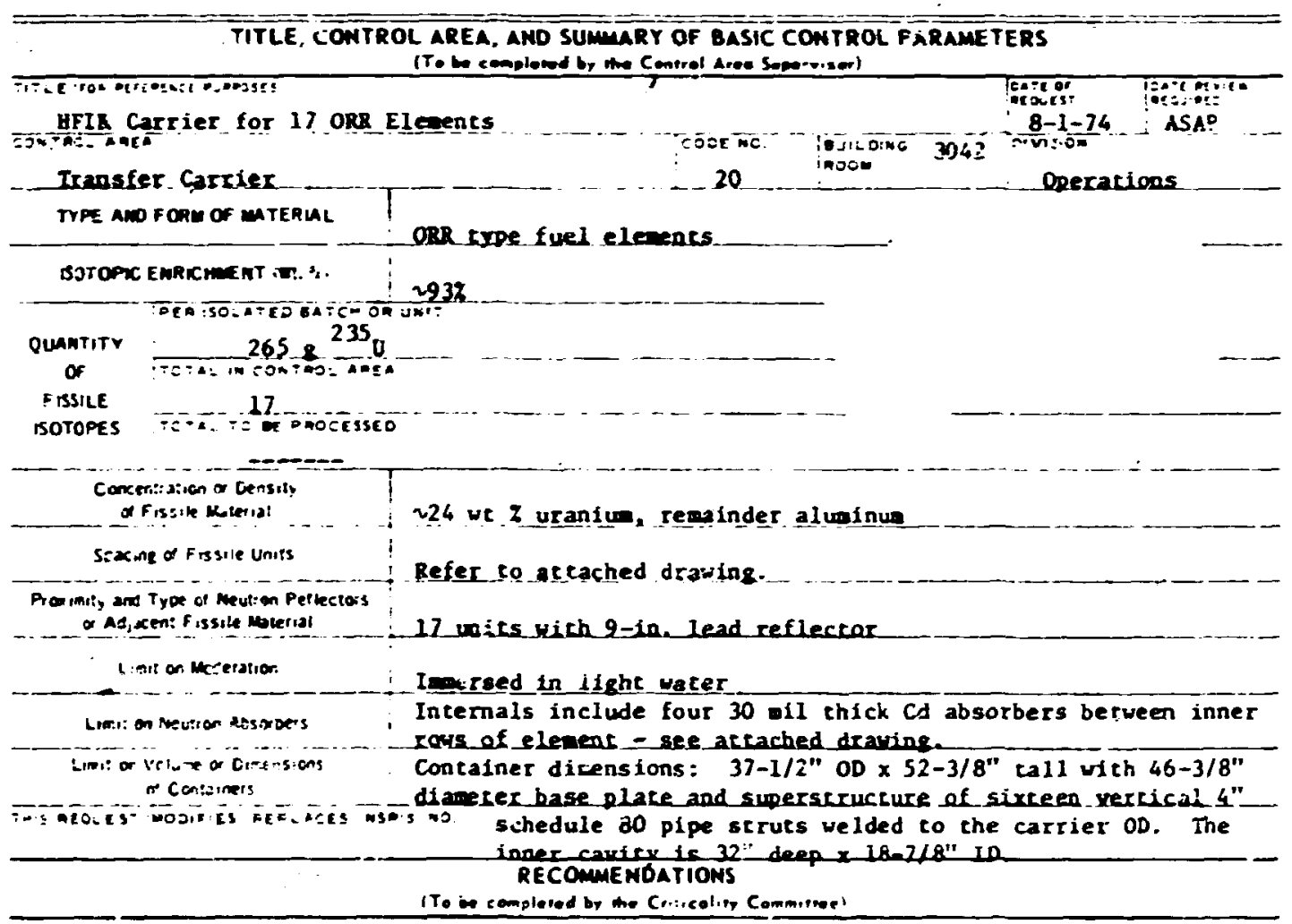

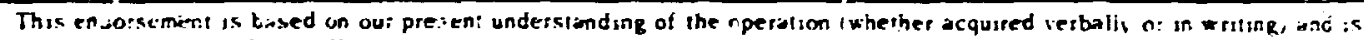
subjer, to revile end cincellation.

An $3 \times 8$ array of 64 each $300-g$ Spert $D$ clemeats with 0.025 in. thick cadmium between rows was subctificsl when spaced $0.5 \mathrm{in}$. for optimow woderation. The arrangement proposed fo: 17 each 265-g ORR elements in the HFIR Shipping Cask having 0.030 inch thick crdafium between row will also be subctitica: and is approved int use.

The presence of the cadmium shruld be verifled after construction of the partitions for the cask as part of the Quality Assorance Procedures.

IE. B. Johnson \& R. R. Reedy, "Critical Experients vith Spert-D fuel Elements," ORNL-TH-1207 (July, 1965)

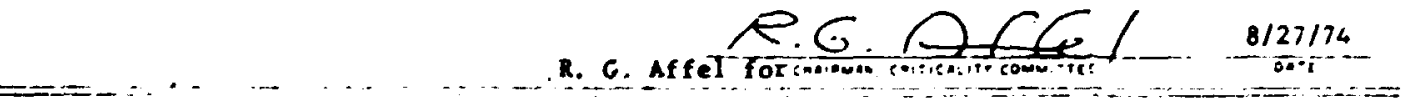


PROVISIONS FOR NUCLEAR CRITICALITY SAFETY

To bo conelored by to Conr-al aree Sugervisori

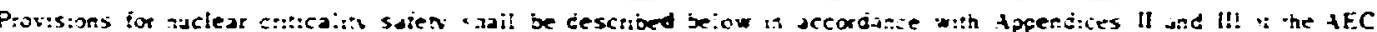

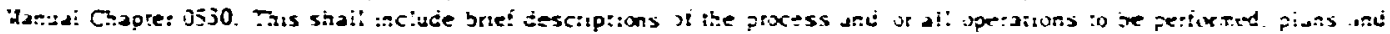

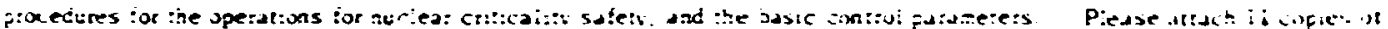
referetced tiaxings and ducimenis.

The HFIR element shielded cransfer casi dill receive che 17 place jasket (drauing actacinef) wich is equipped aici four sadniug-íilled dividers jetueen che innerzost rous of spases. So equipped, che HFIR casix dill be used co cransier i7 ORR or 3SR elements from ORVL co of $\bar{f}$-sice, fiemical processing plancs. The elemencs silpped are nomally depleced ( $120 \mathrm{~g}$ U/element) but may contain as such as

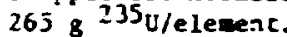

Elements will be transferred under water from approved storage locations to tie compartments uichin the basiet, afcer che baskec icself ias been placed in the HFIR cask. The elenents, minus end fitcings, will rest against cne perforated piate in the boctoo of the basket, and will occupy $-25-1 / 2 "$ of che dvailable 29-1/2" of head roon. Afcer che eiemencs are Ioaded, che cask Iid will be replaced underwater. At this point in che procedure, the jasicet will be surrounded on all sides by "9" of lead shielding contained in "1/2" stainiess walls. The warer enveiope around the fuel will vary in thiciness from in at tie top to less han I" ac selected points on the sides.

ORML

CRITICALITY COMITTEE

NSR 747

Creication jatc

July, 1977

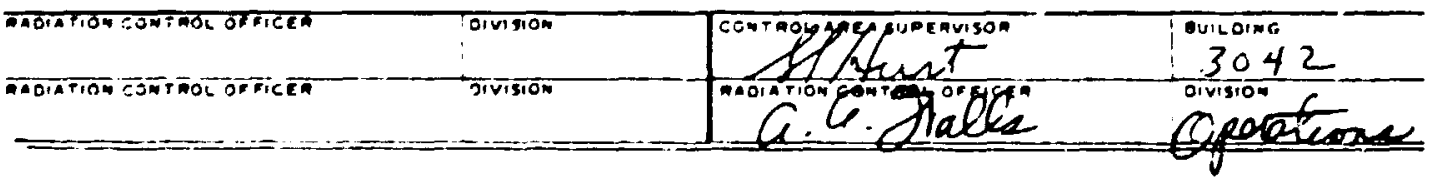


Copy to R. C. Austin

\section{REQUEST FOR MUCLEAR SAFETY REVIEW}

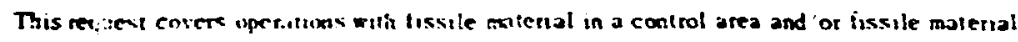

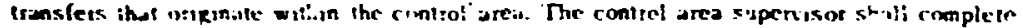
the blocks below and dexcribe ihe prucess and or operations to be performed. emphasizing the provisions for nuclest caiticalits sufety on the reverse side of thus page. This request stall be appruicd by the R.udution Control Officers of the orminating Division and the Division(s) to which fistic mintcrial will be transfe:red.

ORML.

CRIIICALITY COETTIEE

$\operatorname{MSR} 7851$

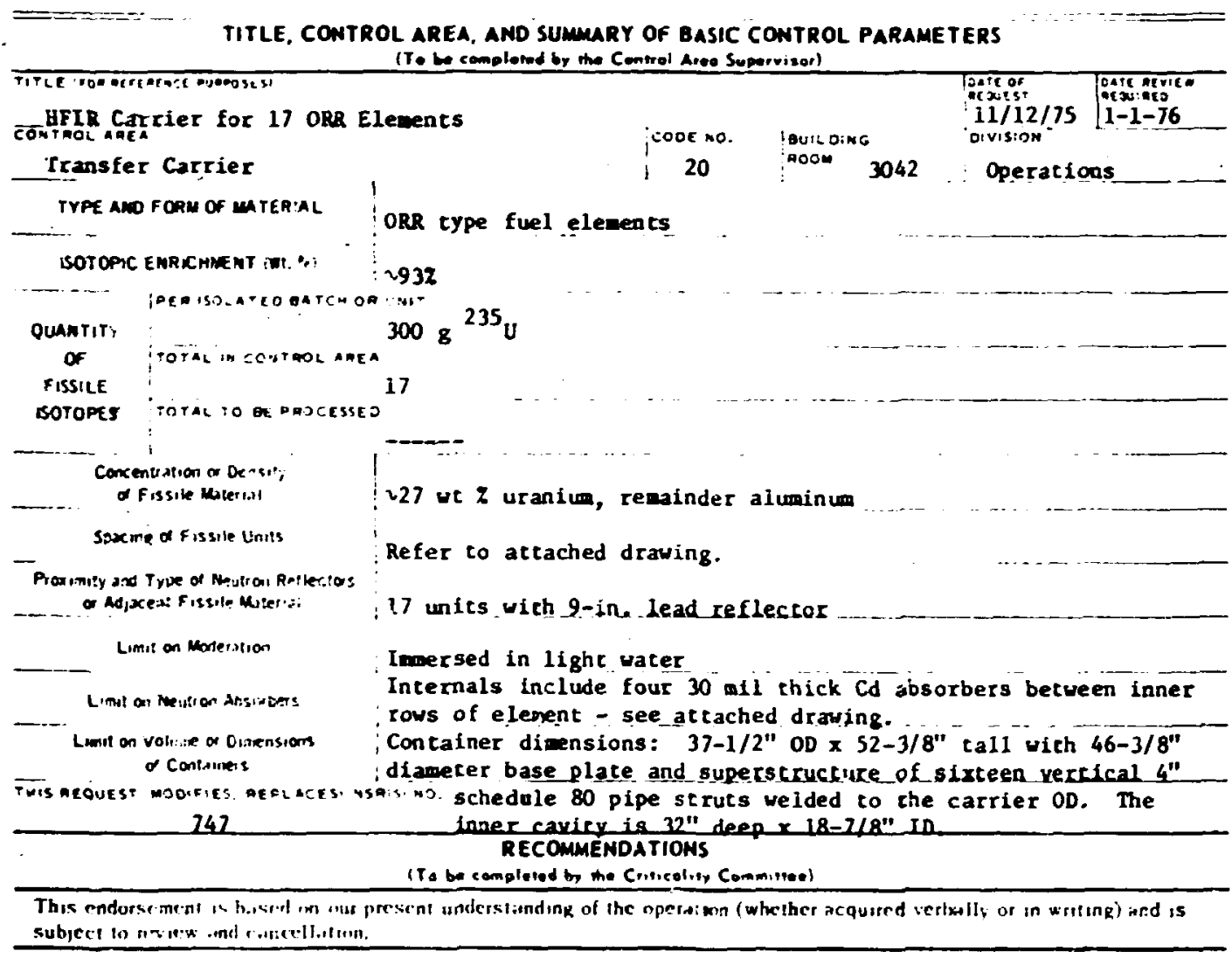

Seventeen (17) $300 \mathrm{~g}$ elements having $30 \mathrm{mil}$ Cd between rows will be

subcritical. (Ref. ORN-R+1207). This request is approved. 
PROVISIONS FÖ NUCLEAR CRITICALITY SAFETY

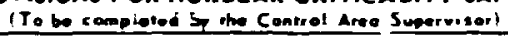

Provis:ons for nuclear crst:cality sulety shall be described below in deciedine with Appendices II and III of the AFC

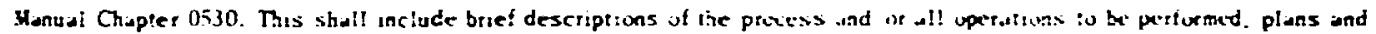

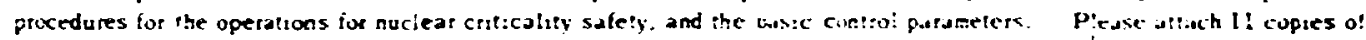
referenced drawings and doctirents.

ORMR

CRITIAALITY COHATTEE

NSR 7851

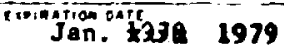

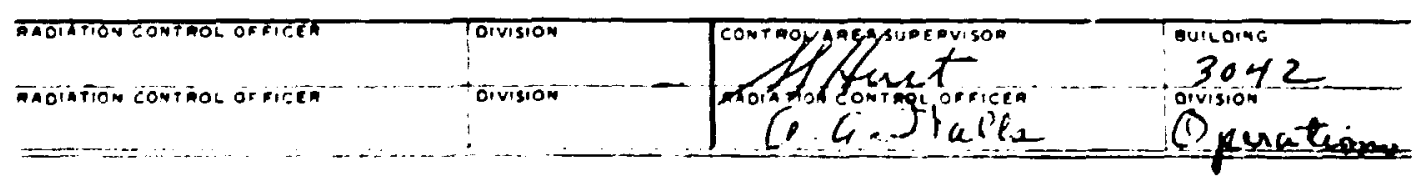


Appendix $\mathrm{J}$

QUALITY ASSURANCE PROGRAM PLANS 


\section{INTRA-LAEORATORY CORRESPONDENCE \\ oAK RIOGE HaTIONAL LaBoratory}

October 1, $19 ? 4$

To: Distributioa

Subject: Quality Assurance Program Plan OP-11481 for the Fabrication of ORR Spent Fuel Element Storage Magazine

The subject approved plan is transmitted for your information and use.

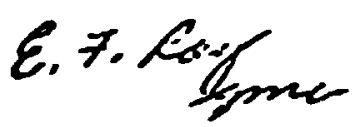

R. F. Roy

EFR:ge

Enclosure

DLetribution: C. A. Bowden

C. D. Cagle

W. R. Casto

J. A. Cox

J. H. Evans

S. S. Hure

R. A. Jones

J. R. McGuffey

R. H. Neill

C. B. Plerce 
228

QUHLITY ASSURANCE PROGRAY PLAN

$$
\text { OP-11481 }
$$

PABRICATION OF ORR SPEVT FUEL ELEIENT STORAGE MAGAEINE

SEP 24 19?:

Spproved:

Deslgn Englneer

QAC, Operations

Project Leader

Laboratory QA Director

Submitced by:

Project Englneer
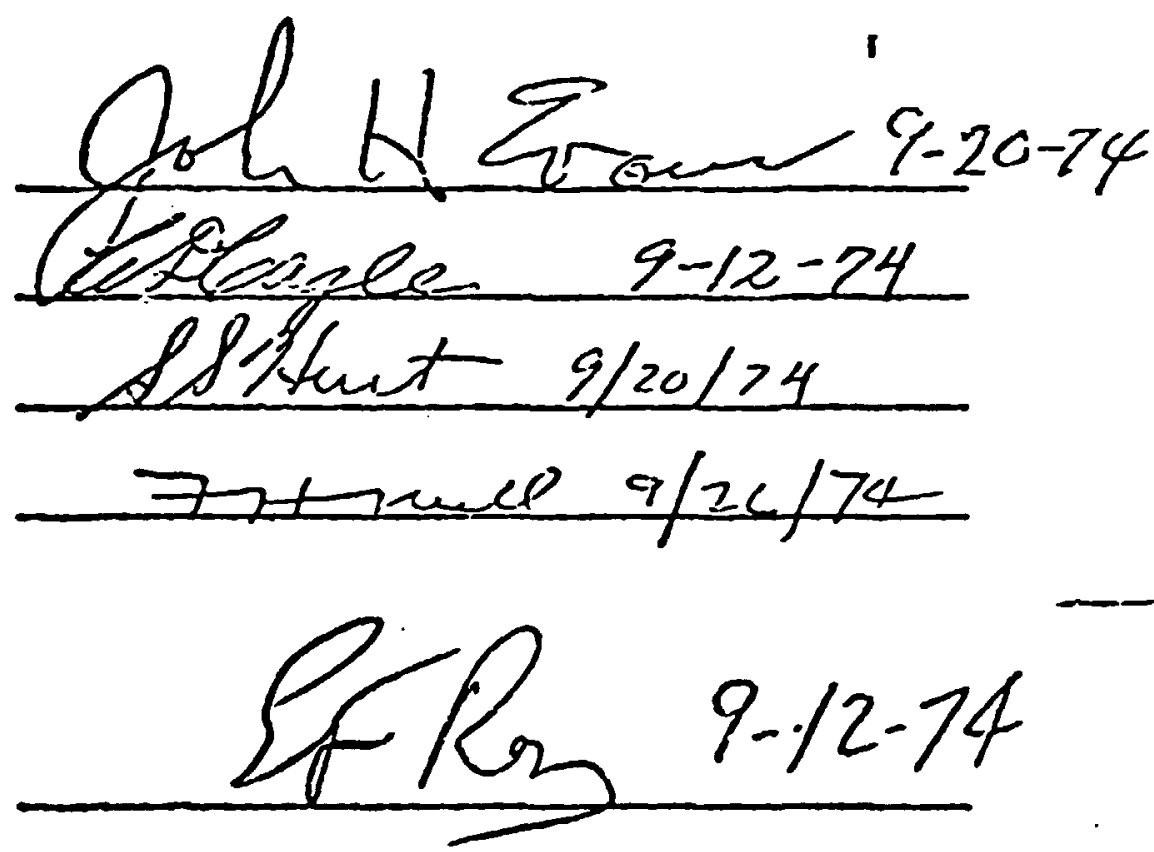

6 
1. INTRODUCTION

The KFIR spent fuel element shipping cask is a lead filled carrier that meets the standards of DOT for the tzansportation of depleted fuel elements between the HFIR and 1 ts spent fuel elenent reprocessing plant. This plan is to cover the fabrication of an ORR spent fuel element storage magazlne that will fit Inside the HFIR cask and further utilize its services.

\subsection{Scope}

This plan describes the quallty assurance regifrements and designates the responsibllitics for the fabrication of an ORR spent fuel element storage magazine.

\subsection{Qualicy Level}

In accordance with ORNL SPP-39 and QA-I-1-102 fairfcation shall comply to Quality Assurance Standards Level II. Designation as Qualtty Level II work $1 \mathrm{~s}$ approprlate because the ORR spent fuel element storage agazfne when in use will preclude the possibility of a criticallty problem.

\section{PLANING}

Planning shall be in accordance with URM QA procedures and Operations Division supplenents.

\subsection{Respor.s1b111ty}

The assignment of project responsibllity is shown In FIgure 1 and Tahls 1. 
a. Quality assurance planning by $C_{\bar{r}}$ scations Division.

b. Storage magazine design by the Profect Leader anu ORVL

- Englneering.

c. Technical review by Operations Division personnel not Involved In the actual project work. Criticality review by Director's DIvision Criticality Comenttee.

d. Design approval by the Project Leader, the Dasign Engineer, and the Quality Assurance Coordinator.

e. Preparation of prosurement documents and spectfications by the Profect Leader and the Design Engineer.

f. Fabrication by ORNL P\&E Division.

8. 111 material, weld, and dimensfonal acceptance by joi Inspector.

h. QA audit by Opexations Division. Audit to be performed in accordance with ORAL QA-I $8-100$ after the fabrication of fuel storage magazine.

2.2 Design and Manufacturing Documentation The following are required:

a. Design criteria is on file in BIdg. 1000, Roon 229C.

b. Katerial specifications.

c. Dest8n drawhg (by 0RNL): K-10191-EL-010-D.

d. Procedures for fabrication and Inspection.

c. Techulcal review approvals as shown on drawings and/or in wrieng.

2.3 Ronconformance Documentation

In accordance with $0 R M R$ Q $-L-6-101$ nonconforming 1 tem shall be 1dentifled. Any norconformance shall be documented with coples to 
Project Leader, particlpatlag QAC, and the Q:D. Only those nonconforming 1ters approved by Project Leader, Desłgn Eriglneer, and Opcrat:ons QAC ciay be used.

2.4 Quality Records

The following documents are required and are subject to audit.

a. Design and manuéacturlng docurents (see Section 2.2).

b. Document control tabulation.

c. Materlal certffcations, Including Inspection report8.

d. Manufacturing and Inspection plans.

C. Reports as required by Inspection Englneering Manual, Sections 2. 3, and 4.

f. Helding procedures.

8. Welder qualiflcation test rẹports if required by the spectfled welding procedures.

b. Certification of all test results and test reports.

1. Dimensional Inspection reports as speclfled and nonconformance reports as requlred by ORHz QA Manual, Section 6.

1. Fallure and incident reports, if any, as required by ORIL QA Manual. Section 6.

The quality records w11 be located as shown in Table II.

\subsection{Approvals}

All manufacturing and Inspection plans shall be approved by the. Project Leader and the partlcipating QAC before fabrication starts.

\section{DESIG}

Design is in accordance wlth ORNL drawing M-10191-EL-010-D. 
- The requirements of the following specifications and etandards of:1 be zet:

a. OBNL Quality Assurance Program Requirements.

b. Inspection Engíneering Manual.

a. All speclfications as 11 sted In the Document Control rabulation.

4. PROCUREMENT

Operations Division vill be responslble for the procurement of all material. This includes, If required, the preparation of all purchase requisitions and material specifications.

\section{FEBRICATION}

The ORR spent fuel element otorage magazine wlll be fabricated by the ORRL PSE DIVlston.

\subsection{Instrument Callbzation}

All Instruments used for measuring and testing of fabricated

elements for acceptance shall be callbrated before use in accordance with ORAR QA Erocedure QG-L-14-100.

\subsection{Iinal Acseptance}

Final acceptance of the storige magazine wlll be by the Froject Ieadei of his designated representr.tive.

\section{STORAGE}

The storage magazIne wIII be stored In BIdg. 3042. 


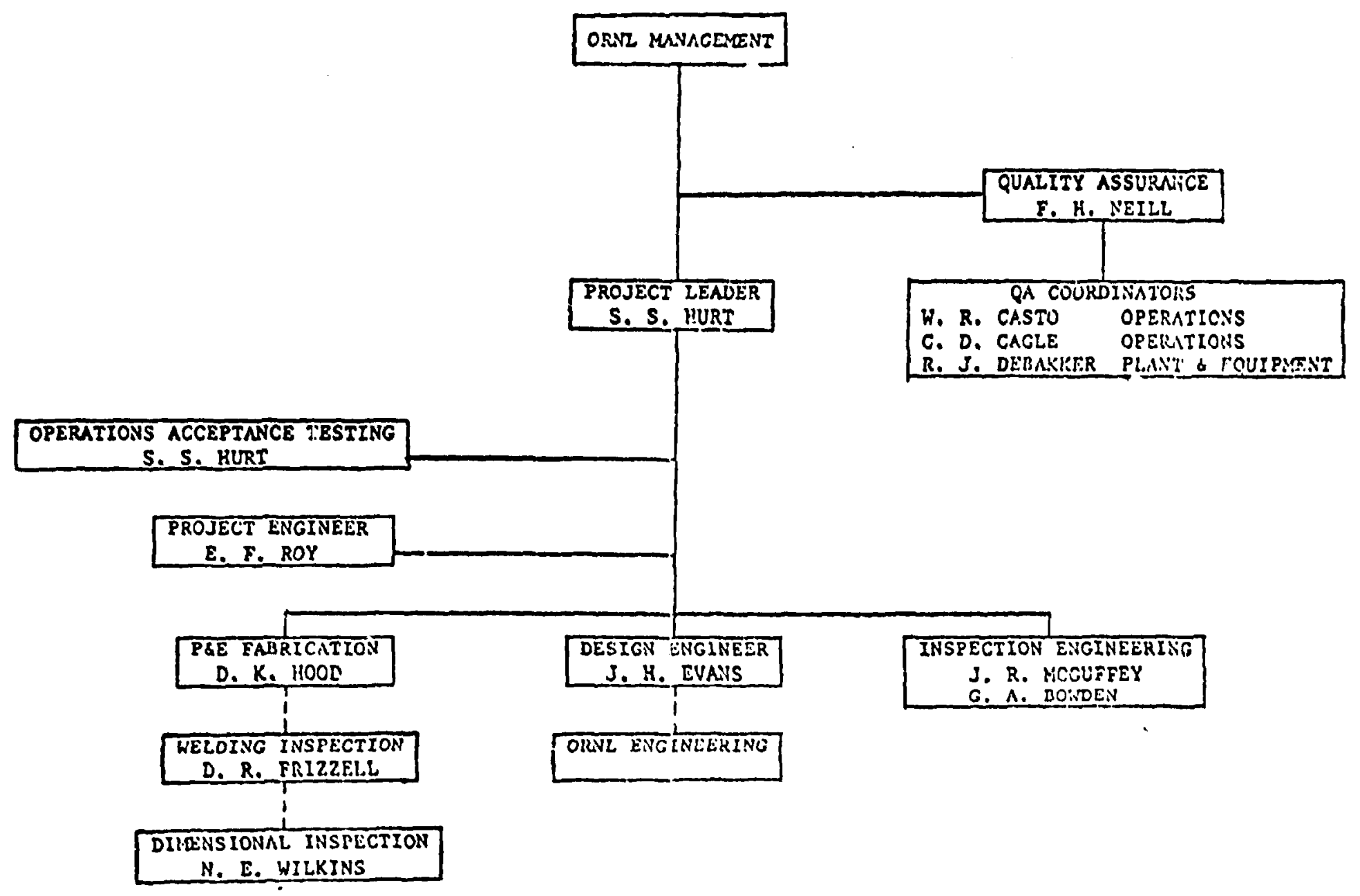

F1gure 1. Functiona:- Organlzat1on Chart

Fabrication of CRR Spent Fuel Element Stosage Magazine 
When approval of this SARP is recelyed, a quality assurance progran plan sintlar to the preceding document will be prepared for the cask nodifications. 